\title{
QK605.5
}

.N5

S3

Schwarze, Carl A

The parasitic fungi of New Jersey 


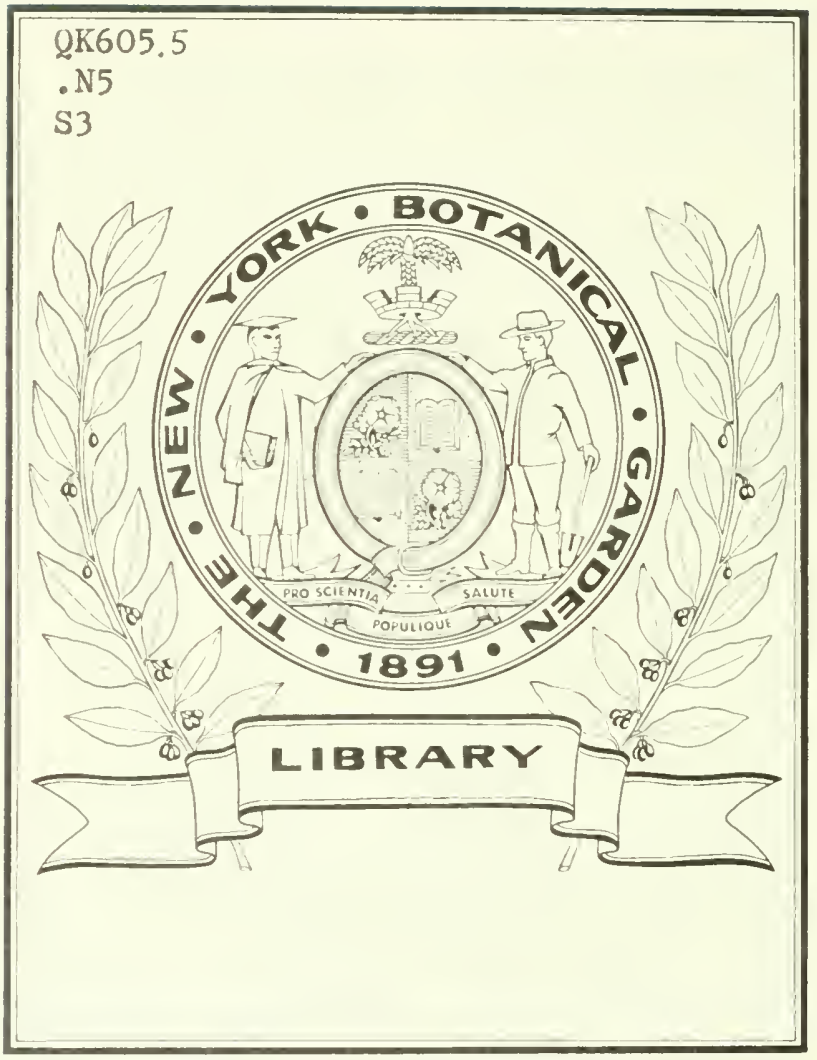




THE PARASITIC FUNGI OF NEW JERSEY

\section{NEW JERSEY}

\section{AGRICULTURAL}

\section{Experiment Stations}

\section{BULLETIN 313}


NEW BRUNSWICK, N. J.

\section{TATE STATION. ESTABLISHED 1880. BOARD OF MANAQERS.}

His Excellexcy WALTER E. EDGE, LLD...... Trenton, Governor of the State of New Jerses. W. H. S. DEMAREST, D.D.........New Brunswick, President of the State Agricultural College. JACOB G. LIPMAN, PH.D..........Professor of Agriculture of the State Agricultural College

\begin{tabular}{|c|c|c|c|c|c|}
\hline County & Name & Address & County & Name & Address \\
\hline Atlantic & William A. Blair & Elwood & Middlesex & James Neilson & New Br \\
\hline & Arthur Lozie & rood & Mont & Willi & \\
\hline ngton & Lippincott & wn & Morris & John C. Welsh & lley \\
\hline den & raim T. Gill & field & Ocean & h Sapp & ton \\
\hline May & les Vanaman & 'reek & Passaic & A. Serven & Clif \\
\hline berland & F. Seabrook & $\mathrm{B}$ & Salem & es R. Hires & Sale \\
\hline & Beckett & boro & Somerset & Joseph Larocque & Bernardsvilte \\
\hline & Bahrenburg & Hill & & mstr & \\
\hline & (1.0 & & & Tatfield & Scote $\rightarrow$ \\
\hline & T. Allinson & & Varren & ooke & \\
\hline
\end{tabular}

STAFF.

JACOR G. LIPMAN, PH.D............. Director.

FrANK G. HELYAR, B.Sc............. Associate in Station Administration.

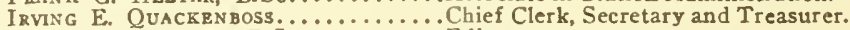

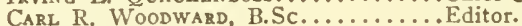

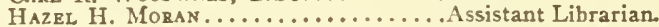

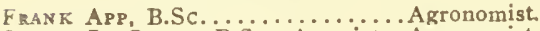
Irving L. Owen, B.Sc..Associate Agronomist. J. Marshall Hunter, B.Sc.

Animal Husbandman.

Charers S. Cathcart. M.Sc......... Chemist.

RaLPH L. Wm.LIS, B.Sc.......Assistant Chemist. ARCHIE C. WARK......... Laboratory Assistant. W. ANDRBW CRAY....... Sampler and Assistant. Harry C. McLran, PH.D.. Chemist Soil Res'h. Wrutam M. REgAN, A.M. Dairy Hushandman. Wules B. CoMbs, A.M.,

Assistant Dairy Husbandman.

Thosas J. HeadleE, PH.D...... Entomologist. Chas. S. BecKwItI, B.SC., Asst. Entomologist. Mitchell Carroll, B.Sc...Asst. Entomologist. Mauricb A. Blake. B.Sc........Horticulturist. VINCENT J. BREAZEALE,

Foreman, Vegetable Growing.
Charles H. Connors, B.Sc.,

Assistant in Experimental Horticulture ARTHUR J. FARLEY, B.Sc.

Specialist in Fruit Studies.

IVILLAAM SChIEFERSTEIN......Orchard Foreman. LyMAN G. SChrRMERHORN, B.SC.

Specialist in Vegetable Studies.

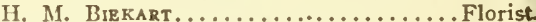
HARry R. LEWIS, M.Agr.. Poultry Husbandman. WILLARD C. THOMPSON, B.Sc., Assistant Poultry Husbandmax RaLston R. Hannas, B.Sc.

Assistant in Poultry Research. Mírris Sizgel............... Poultry Foreman. ElMER H. IVENB...........Poultry Foreman. JoH P. HeLYar, M.Sc.......... Seed Analyst. JesSir G. Fiske, PH.B...... Asst. Seed Analyst.

\section{AGRICULTURAL COLLEGE STATION. ESTABLI8HED 1883. BOARD OF CONTROL.}

The Board of Trustees of Rutgers College in New Jersey.

\section{EXECUTIVE COMMITTEE OF THE BOARD.}

IV. H. S. DEMAREST, D.D., President of Rutgers College, Chairman...... New Brunswick.

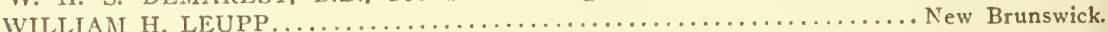

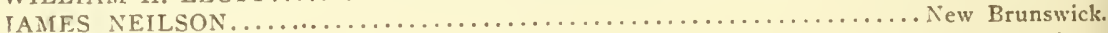

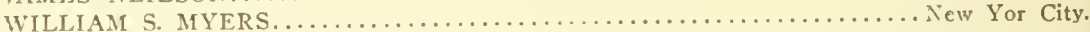

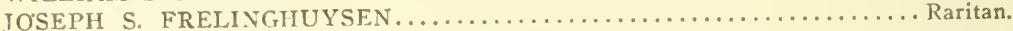

I. ARMORY HASKELL...

\section{STAFF.}

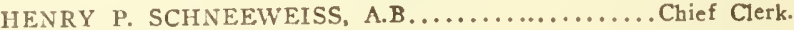

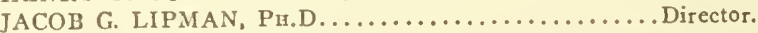

Byron D. Halsted, Sc.D........... Botanist. JoHN W. SHIVE, Pr.D...... Plant Physiologist. EARLE J. OWEN. M.Sc.....Assistant in Botany. FREDERICK W. ROBERTS, A.M. Assistant in Plant Breeding. Mathilde Groth.......................... THOMAS J. HEADLBE, PH.D...... Entomologist. Alvar Petrrson, PH.D.....Asst. Entomologist.
Augusta E. Mrskr.... Stenographer and Clerk. Melville T. Cook, PH.D....Plant Pathologigt. JACOB G. LIPMAN, Pil,D. Soil Chemist and Bacteriologist. Augustine W. Blaik, A.M.

Associate Soil Chemist Cyrus Wrtmer, Field and Laboratory Assistant.

- Staff list revised to April 1, 1918. 
NEW JERSEY STATE AGRICULTURAL COLLEGE

DIVISION OF EXTENSION IN AGRICULTURE AND HOME ECONOMICS

ORGANIZED 1914

Alva Agez, M.Sc., Director and State Superin. tendent of County Demonstration.

Victor G. Aubry, B.Sc., Specialist, Poultry Husbandry.

John IV. Bartlett, B.Sc., Specialist, Dairy Husbandry.

Roscoe W. DeRaun, B.Sc., Specialist, Market Gardening.

T. B. R. Dtckey, B.Sc., Specialist, Soil Fertility and Agronomy.

William B. Duryee, B.Sc., Specialist, Farm Management.

Marjory Eells, D.S., Home Demonstration Agent.

EDnA GuLCK, Home Demonstration Agent.

William H. Hamilton, B.Sc., Assistant State Leader of County Demonstration.
Join H. HANKINSON, A.B., State Leader of County Demonstration.

11. Anna IIAuser, B.Sc. Home Demonstration Leader.

Artilur M. IIUlaert, State Leader of Hoys' and Girls' Club Work.

Sara T. Jackson, B.S., Assistant State Club Leader.

Ethel Jones, M.A., Asse State Club Leader.

William F. Knowles, A.R., Assistant Siate Club Leader.

Willum M. McIntyre, Assistant Specialist, Fruit Growing.

Helen E. Minch, Specialist, Home Economics Charles H. Nissley, B.Sc. Sdecialist, Fruit and Vegetable Growing.

CARL R. WOODWARD, B.Sc. Editor.
Paul B. Bennetch, B.Sc. Demonstrator for Sussex County.

Frank A. Carroll, Demonstrator for Mercer County.

Elwood I. Chase, B.Sc. Demonstrator for Gloucester County.

Bertha Cold, B.Sc., Home Demonstration Agent for Jersey City.

Louss A. Cooley, B.Sc., Demonstration Agent for Ocean County.

Margaret M. Cornell, B.Sc., Home Demon stration Agent for Trenton.

Herbert R. Cox, M.S.A., Demonstration Agent for Camden County.

Josephine C. CRAMER, Home Demonstration Agent for Middlesex County.

Lee IV. Crittendon, B.Sc., Demonstrator for Middlesex County.

Ellwood Douglass, Demunstrator for Monmouth County.

Clara P. ForTe, B.Sc., Home Demonstration Agent for Burlington, Camden and Gloucester Counties.

HarRy C. HaINes, Demonstration Agent for Somerset County.

Margaret H. IIArtaets, Home Demonstration Agent for-Paterson.

Margaret C. Hayes, Home Demonstration Agent for Morris County.

WILliam A. Ilouston, Assistant Demonstration Agent for Sussex County.
Lauretta P. James, B. Sc. Home Demonstra tion Agent for Mercer County.

Eleanor K. Jounston, B.Sc. Home Demon stration Agent for Elizabeth.

PhiLip F. KeIL, Demonsiration Agent for Bur lington County.

Harvey S. Lippincott, B.Agr. Demonstrator for Morris County.

L. F. Merrill, B.Sc. Demonstrator for Bergen County.

WarReN IV. Oley, B.Sc, Demonstrator for Cumberland County.

Regine Porges, B.Sc., Home Demonatration Agent for Passaic.

Caroline R. Simons, Home Demonstration Agent for Camden.

JAMES A. Stackhouse, B.SC. Demonstratur for Cape May County.

Eunice Straw, B.Sc. Home Demonstration Agene for Monmouth County,

W'alter C. Vail, B.SC.. Demonstrator for Salem County.

Loursa VANuxes, Hone Demonstration Agent for Newark.

Ruth WALLIS, A.B., Home Demnnstration Agent for Perth Amhoy.

HaRRIOT IVARE, Y.A. Home Dem nepration Agent for Bayonne.

HAROLD E. WETTYEN, B.Sc. Demonstration Agent for Passaic County.

Caroly F. Wetzel, Home Demonstration Acent for Bergen Counev.

Albert E. WILKINSoN, M.AGR., Demonstration Agent for Atlantic Countv 



\section{New Jersey}

\section{Agricultural Experiment Stations}

\section{Bulletin 313}

The Parasitic Fungi of New Jersey

$$
\text { BY }
$$

CARI, A. SCHIVARZE, M.A.

New Brunswick, N. J.

September, 1917 
QK6
.N5
S3 


\section{PARASITIC FUNGI OF NEIT JLRSEY}

\section{INTRODUCTION}

This work is the gradual outgrowth of a plan devised to increase the knowledge pertaining to the parasitic fungi of the state of $\mathrm{New}$ Jersey. In developing this plan the writer drew frcely from such works as, Catalogue of Plants Found in New Jersey by Dr. N. L. Britton (in the Geological Survey of Nezu Jersey, Report of the State Geologist, 1889, v. 2, pt. 1, p. 25-642), reports and bulletins of the New Jersey Agricultural Experiment Station, North American Pyrenomycetes by Ellis and Everhart, North American Flora, Mycologia, Bulletin of the Torrey Botanical Club. Grerillea, Procecdings of the Philadelphia Academy of Natural Scicnce, and publications of the United States Department of Agriculture.

The writer had ample opportunity during the summers of 1912 to 1917 , inclusive, to collect and preserve parasitic fungi in the state of New Jersey. This material and "fungi exsiccati" deposited in the herbaria of the New Jersey Agricultural Experiment Station and the New York Botanical Garden afforded the writer excellent opportunities to study the fungous parasites.

The plan formulated at first was to list all fungous parasites recorded for the state of New Jersey and supplement this list with their descriptions and drawings of specimens illustrating the respective genera. This plan, however, was abandoned because many specimens collected and recorded by the pioneer botanists had been incorrectly determined. It was finally decided to publish descriptions and illustrations only of those species which had been stndied in the laboratory.

Whenever possible, specimens collected in New Jersey were studied. When no New Jersey material was available specimens from neighboring states were examined.

To gain a broader view of the nature of fungous parasites, cultures were made in many cases on agar media or on the natural host. Whenever possible, therefore, spore measurements and the growth on nutrient media were compared with those displayed hy the para- 
site on its natural host. In case the original descriptions were meager, inaccurate or obsolete, the descriptions were amplified. Credit is given at the proper place when the description is taken verbatim from a monograph, etc.

All the drawings are original and were made by the author. The same microscope and camera lucida were used and therefore all the fungi were drawn on a uniform scale. The magnification in every instance is appended to the description.

To avoid confusion a generic name of long standing was used. A reference at the proper place was made to the recent terminology. The writer wishes to thank the members of the staff of the New York Botanical Garden for the permission to examine specimens in the Cryptogamic herbarium, for the library facilities and for many helpful suggestions. The writer is also under great indebtedness to Prof. J. C. Arthur, who not only determined the rusts but freely offered advice and criticised that portion devoted to the Uredinales, to Dr. G. P. Clinton for determining the smuts, and to Prof. F. C. Stewart, Geneva, N. Y., Doctors R. A. Harper, IV. A. Murrill, F. J. Seaver, A. B. Stout, Donald Reddick, I. B. Stewart, C. L. Shear, J. J. Davis and F. D. Fromme for helpful suggestions.

The writer is also under great indebtedness to Prof. Melville Thurston Cook, head of the Department of Plant Pathology of the New Jersey Agricultural Experiment Station, who directed the work, for his encouragement, advice, helpful suggestions and cooperation in preparing the descriptions, for the arrangement of the plates and for reading the proof. 

PlasModiophora BRASSic E Wor.-On the roots of cabbage, cauliflower and related plants. Causes enlargement of the infected parts which are commonly known as "club root" or "finger and toe" disease. The organism lives within the parenchyma cells and stimulates both the infected and the neighboring cells. The medullary rays and cortex become thickened; the sclerenchyma cells suppressed. xylem reduced, and the phloem increased.

1. Diseased cabbage seedling. 2. Diseased root of older plant. 3. Crosssection of diseased root showing organisms within certain cells, 2/3. 4. Plasmodium in cells, $1 / 6$. 5. Plasmodium in 4 distinct divisions showing multinuclei, 1/6. 6. First stage in the formation of spores, 1/6. 7. Second stage in the formation of spores, 1/6. 8. Mature spores, 1/12. 9. Division of spores, $1 / 12$.

Synchytrium VACCINII Thomas.-On the cranberry and also on Gaultheria procumbens, Cassandra calyculata, Kalmia angustifolia, Izalea riscosa, Clethra alnifolia and Gay'lussacia sp. and I'accinium corymbosum. Causes small red galls on stems, leaves, flowers and fruits of cranterry and other hosts. Mycelium absent or scanty, producing the globose sporangium within the center of the gall; many motile swarm spores produced from the sporangium.

10, 11, 12. Galls on various parts of cranberry plant. 13. Cross section of the leaf and gall, $2 / 3$.

Saproleginia Ferax* (Gruith) Thuret.-Grows freely on dead flies in water. The slender hyphre show few septa until the tips are cut off in the formation of the sporangia. Zoosporangia clavatecylindrical. The zoospores are almost spherical or slightly pearshaped, biciliate and very active. After the cmergence of the zoospores, there is a growth from the base cell into the old sporangium. No oospores were observed.

14. Dead fly covered $w$ ith the fungus. 15. The immature sporangia, $2 / 3$. 16. Two stages in formation of the spores, 1/6. 17. Emerging of the zoospores and the new growth into the old sporangium, 1/6. 18. Zoospore, 1/12.

Albugo BLITI (Biv.) Kuntze. - O leaves of Imaranthus hybridus, 1. chlorostachy's, and other species of Imaranthaceae. Causes white to yellowish, prominent, superficial, circular spots, 1-10 mm., which are sometimes confluent. Conidiophores hyaline, cylindric, about $15 \times 60 \mu$. Conidia hyaline and nearly spherical, 8-15 × $15-20 \mu$.

* Syn. S. ferax Amct.

Achlya prolifera Pruigsh.

S. thuretii de Bary.

19. Conidia. 
Albugo Candida (Pers.) Kuntze--On radish, turnip, shepherd's purse and many other species of Cruciferex. Causes white or occasionally light yellow blisters (sori) on all parts of the host above ground. Frequently causing pronounced hypertrophies. Conidiophores hyaline clavate, about $35-40 \times 15-17 \mu$; conidia globular, hyaline, thin walls, $15-18 \mu$.

20. Infected stem of Capsella bursa-pastoris. 21 Infected leaf of turnip. 22. Conidiophores, 1/12. 23. Conidia, 1/12. 24. Mature oospore, 1/12.

Albugo ipomoeae-Panduraxe (Schw.) Swing.-On stems, leaves, and sometimes petioles of the sweet potato, Ipomca pandurata, $I$. hederacea (seedling) and other species of Convolvulacæ. Causes white, or light yellow blister-like spots and sometimes very pronounced enlargements and distortions of the stems. Spots are usually circular, sometimes confluent and $0.5-20 \mathrm{~mm}$. Conidiophores, hyaline, clavate, unequally curved at base, 15-30 $\mu$; Conidi:a hyaline, nearly spherical, slightly cylindrical, 14-20) $\times 12-18 \mu$.

25. Conidiophores and Conidia, 1/12.

Albugo portulaca: (D. C.) Kuntze.--On all parts of Portulaca oleracea above ground. Causes white to yellowish circular or slightly irregular spots ranging to $5 \mathrm{~mm}$. in diameter. Conidiophores hyaline, clavate about $9 \times 25 \mu$. Conidia varying from spherical at base to cylindrical at tip of chain, walls hyaline, contents light yellow, about $12-15 \times 15-22 \mu$.

26. Infected leaf of Portulaca oleracea. 27. Conidiophores and Conidia, $1 / 12$.

ALbUGO TRAGOPOGONis (D. C.) S. F. Gray.-On salsify and many other Compositæ hosts. On the stems and uncler-side of leaves. Sori prominent, deep-seated, white or yellowish, circular or elongaterl. 1- $8 \times 1-3 \mathrm{~mm}$. Conidiophores, clavate, hyaline, 40-50 × 12-15 $\mu$; Conidia, short-cylindric, the terminal larger and less ingular than the lower, membrane with equatorial thickening, hyaline or light yellow, $18-22 \times 12-15 \mu$.

28. Conidium, 1/12. 29. Oospore, 1/12. 
Parasitic Fungi of New Jersey
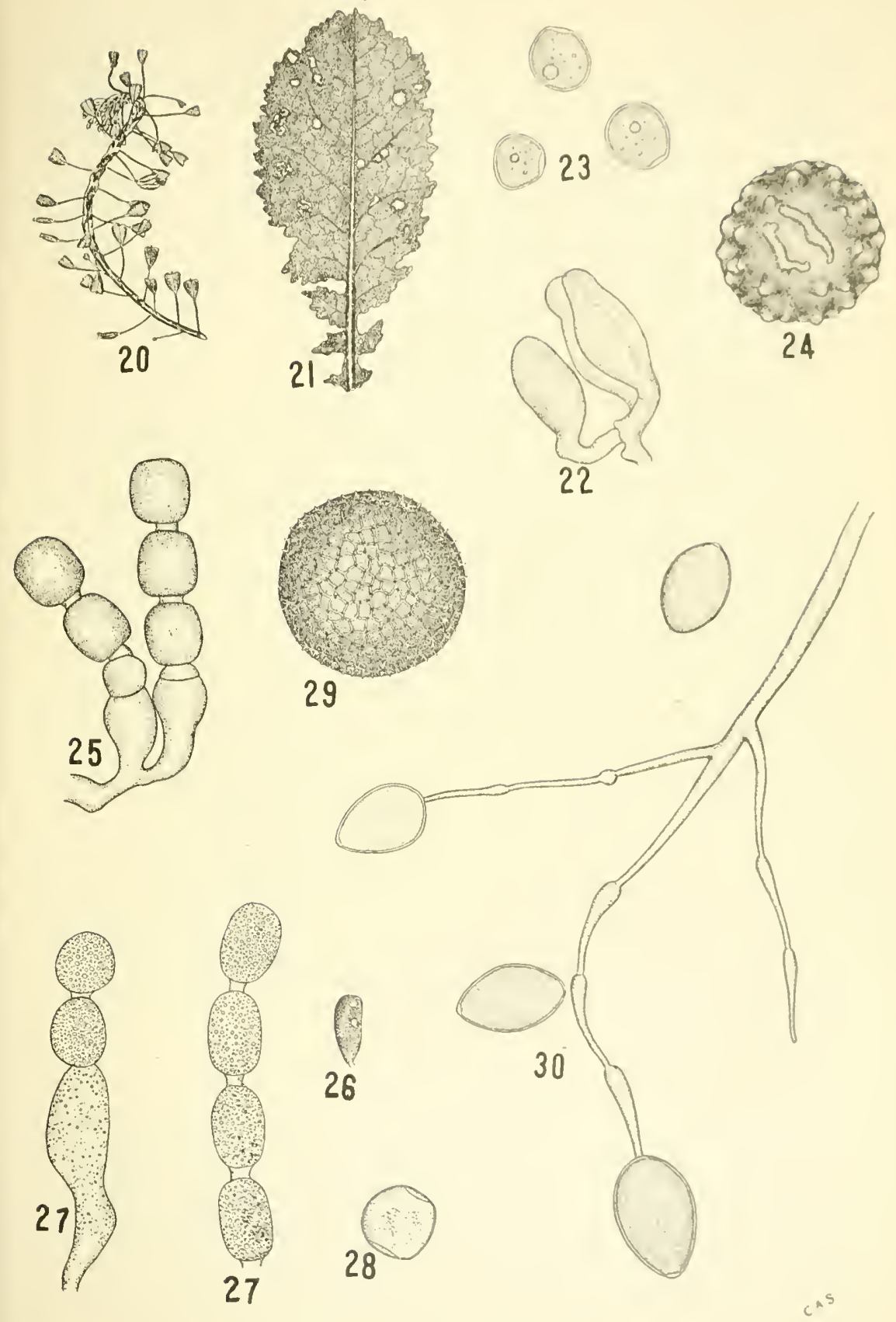
Phitophthora infestaxs (Mont.) deBary. - On leaves and stems and in tubers of the potato. Causes large, dark spots on the leaves, appearing somewhat water-soaked and with abundant white growth on lower surface. Spreads rapidly anc sauses death of plants. Tuber rots, usually beginning at surface; the rot is brow or chocolate-colored, usually irregularly streaked giving a marbled effect. Conidiophores emerging from stomata, single or in clusters of 2 to 4 , branching scorpiose-cymosely; contia ovoid with slight wall near the apex, $2-30 \times 15-20 \mu$.

Common in the mountainous districts of the state and very rare in other parts.

30. Conidiophores and conidia, 1/12.

Phitophtiora PHASEOLI Thaxter.-On pods, yoling shoots, flowers and buds of lima beans. Stunts or completely checks the growths which become covered with a dense white mycelium. The conidiophores emerge through the stomata; are single or clustered, simple or branched from below and cymosely branched above swellings near the tips; conidia oral or elliptic, papillate, $35-50 \times 2+\mu$.

Common throughout the state.

31. Conidiophores and conidia, 1/12. 32. Immature conidium, 1/12.

Rimsotheca austrilis (speg.) Milson. - On leaves of Sicyos angulatus L. Causes spots of rarious sizes and shapes but bounded by leaf veins. Conidiophores arising in clusters from the stomata, $500-650 \times 9-11 \mu$, with 5-7 main branches; the last hranches, $10-1+\mu$. Conidia ellipsoid, $1+-17 \times 10-13 \mu$.

33. Infected leaf of Sicyos angulatus. 34. Conidiophores and conidia, 1/12.

Rirsotmeca gerixin Peck--On the leaves Geranium carolinianum. On the under side of the leat; conspicuous downy white, definite areas; conicliophores fasciculate, monopodially 2-3 branched, branches short, 90-350 $\times 9-12 \mu$; conidia oboroid, hyaline $18-25 \times 15$ $\mu$.

35. Conidiophores and conidia, 1/12.

RHysotheca inalstedi (Farlow) Wilson.--On the lower leaves of Ambrosia artemisiifolia. Originates as small spots finally covering the entire leaf which turns yellow. Conidiophores fasciculate, slender, 300-750 $\mu$, alternately branched 3-5 times, final branches 8-15 long, conidia oral or elliptical, $18-30 \times 14-25 \mu$.

36. Conidiophores and conidia, $1 / 12$. 


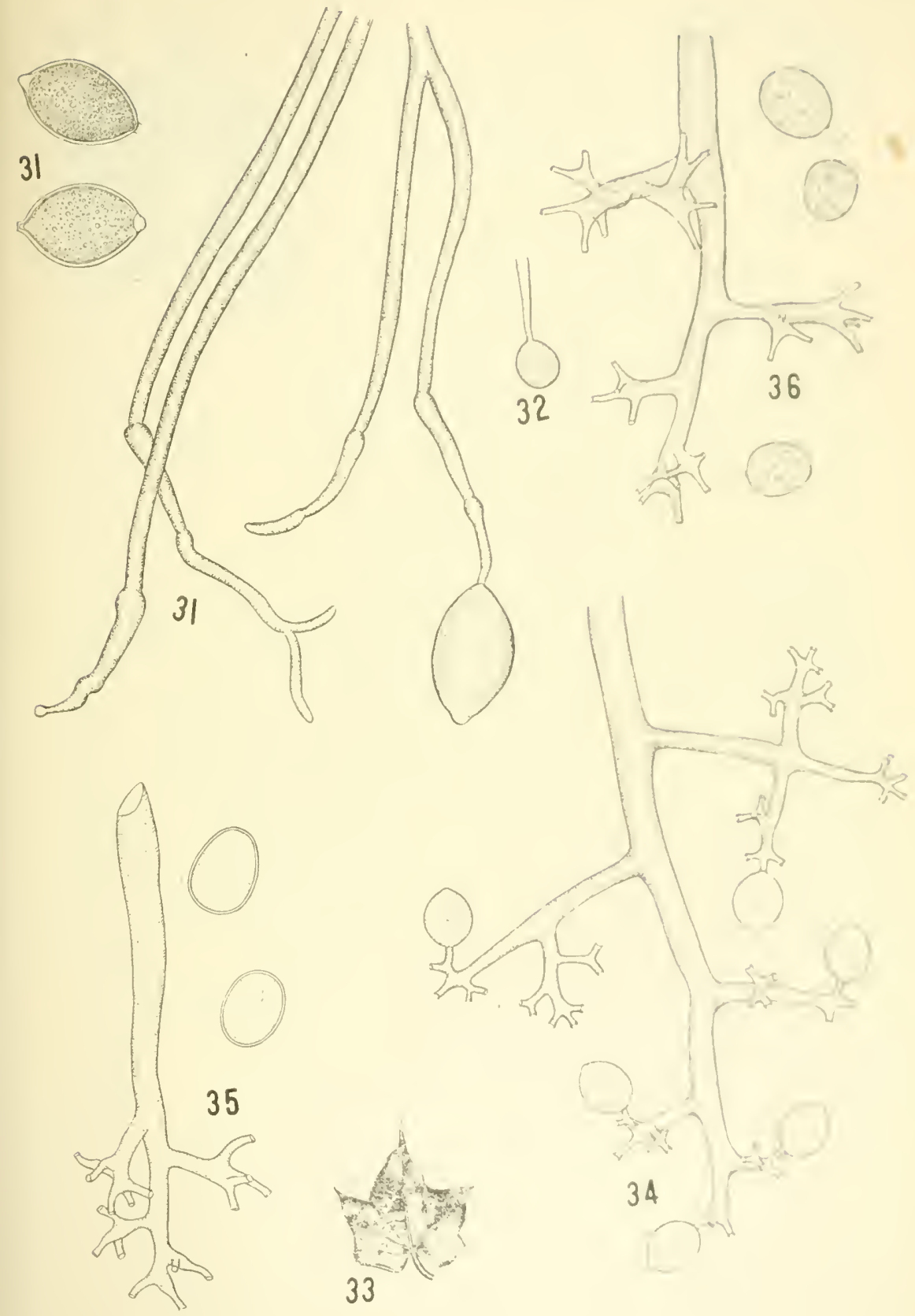


Rhysotheca potentille de Bary:-On the under surface of the leaves of Potentilla. Causes spots bounded by the veins which are yellow above and smoky below. Conidiophores in tufts, 5-6 times dichotomously branched, branches moderately elongated, tips bluntly pointed, conidia ellipsoid, obtuse, smoky-colored, oospores, 20-26 $\times 15-19 \mu$; onspores spherical, yellow, smooth, 22-24 $\mu$ in diameter.

37. Conidiophores and conidia, 1/12.

Rhysotheca viburni (Peck) IVilson.-On leaves of Viburnum lantana. Causes irregular spots with various sizes on margins or along larger veins, covered on under surface with sparing white downy growth. Spot discolorations ranging none to dark reddishbrown or chocolate color. Conidiophores clustered, $300-600 \times 6-8, \mu$, 2-4 branched, last branchlets 6-8. Conidia elliptical, sometimes globose, $15-30 \times 12-15 \mu$.

38. Conidiophores and conidia, $1 / 12$.

Rhysotieca viticola* (B. \& C.) Wilson.-On leaves, stems and snnetimes on fruits of both wild and cultivated grapes. Causes spots of various sizes and forms on leaves, yellowish on upper and whitish on lower surface, hecoming brown with age. Dr. B. D. Halsted also reports it on Parthenocissus tricuspidata (N. Am. Fungi, 2427 b, on "Ampelopsis ritchiii," error for horticultural name of 4. veitchii.) Diseased fruit rot. The affected surface of the stem and fruit and under surface of leaf covered with a white downy growth of aerial hyphæ which become brown. Conidiophores arise from stomata in clusters, $250-850 \times 5-8 \mu$. 4 or 5 times branched, the last branches about 8 . Conidia elliptic-ovate. 9-12 $\times 12-30 \mu$.

Very common in vineyards.

39. Infected grape leaf. 40. Conidiophores and conidia, 1/12.

*Plasmopora siticola. 
Parasitic fungt of New Jersey

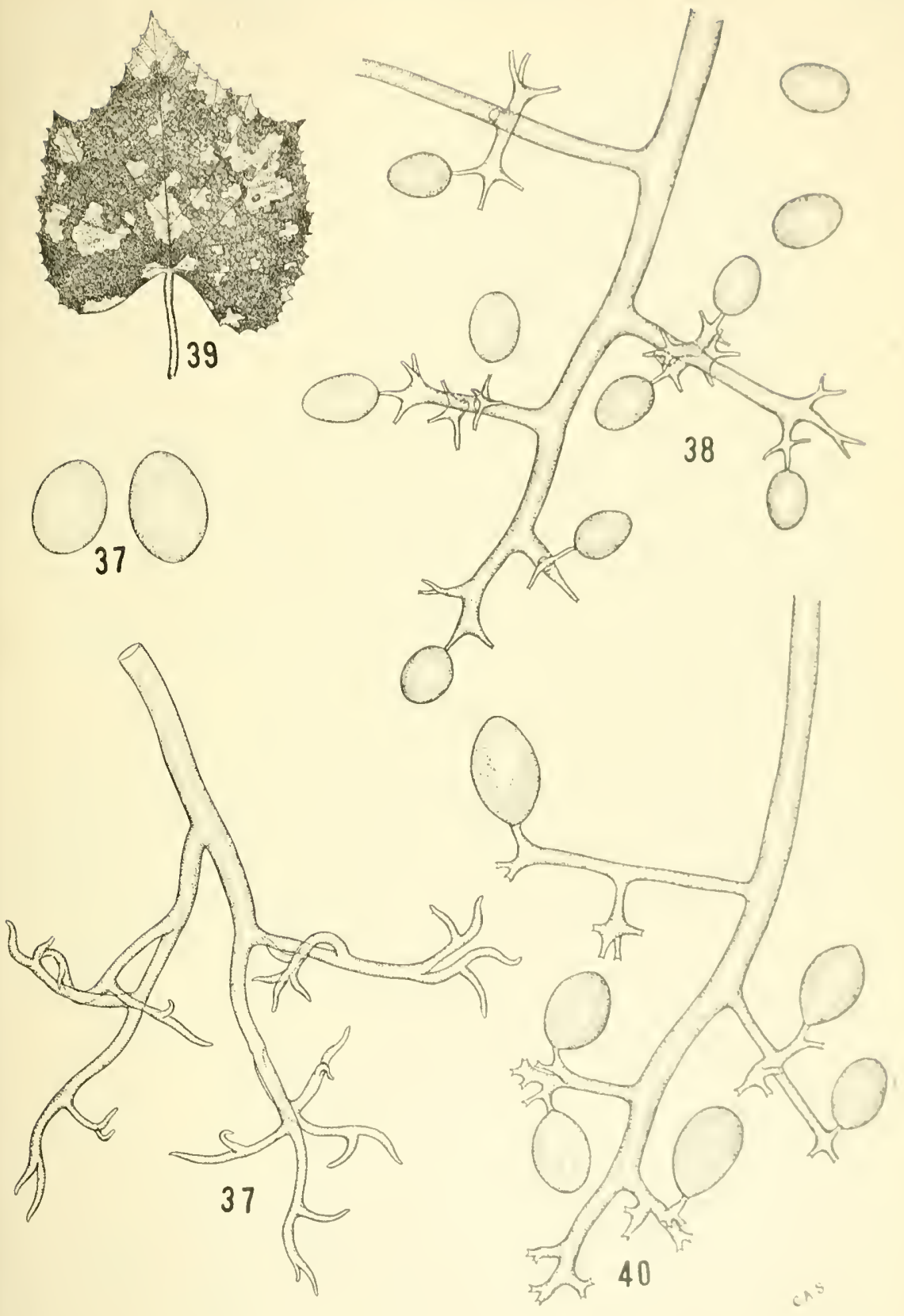


P'SEUdoperoNospora cubensis (B. C.) Rostew--Attacks leaves of cucumbers, cantaloupe and other members of the family Cucurbitaceæ. Causes indefinite, yellow spots which frequently unite; leaf dies, blackens and shrivels. Conidiophores arise from the stomata of the lower surface and sometimes from the unoer surface. $180-400 \times 5-9 \mu, 3-4$, sometimes $2-5$ times branched, forming acute angle; conidia gray or brownish, ovoid to ellipsoid, papillate, $20-40 \times 14-25 \mu$.

41. Infected leaf of cucumber. 42. Conidiophores and conidia, 1/12.

Bremia lactuce Reg.-On the leaves of lettuce and other Compositize. Causes a wilting and dying of the leaves. Conidiophores most common on under surface of leares but sometimes on the upper surface, single, numerous, much branched, each tip bearing a disk with four tips for the spores. Conidia ovate, $16-22 \times 15-20 \mu$.

43. Conidiophores and conidia, 1/12. 
Perojospora effusa (Grer.) Rab.-On leares of spinach and other species of Chenopodiaceæ and on some species of Plantaginacer. Causes water-soaked spots and finally the death of the diseased parts. Yellowish or brownish discolorations on the under side of the leaf. Conidiophores violet-tinted in mass, $150-400 \times 7-9 \mu$, branched with rather wide angles. Conidia ellipsoid to globose, vio let or smoky, $17-18 \times 22-24 \mu$.

44. Conidiophores and conidia, 1/12.

Peronospora lepidi (MicAlp.) Wilson.-On the leaves and stems of Lepidium. Causes a dense white growth with more or less indefinite boundaries. Conidiophores, $130-223 \times 4-9 \mu$, erect, 3-8 limes branched, ultimate branches arising at acute angles about $3-8 \mu$; conidia ellipsoidal or nearly globose, $18-35 \times 15-23 \mu$.

45. Conidiophores and conidia, 1/12.

I'Eronospopa parasitica (Pers.) de Pary-On leaves and stems of most Cruciferæ, among which are the following economic fornus: cabbage, cauliflower, radish, collards, turnips and horse-radisl. Diseased parts are covered with a dense white fungus growth and frequently hypertrophy. Conidiophores densely branched, the last branches very slender and arising at acute angles, 200-300 $24-27 \mu$; conidia elliptical to globose and $12-22 \times 24-27 \mu$, hyaline or nearly hyaline.

46. Infected leaf of radish. 47. Conidiophores and conidia, 1/12. 
Parasitic Fungi of Neiv Jersey

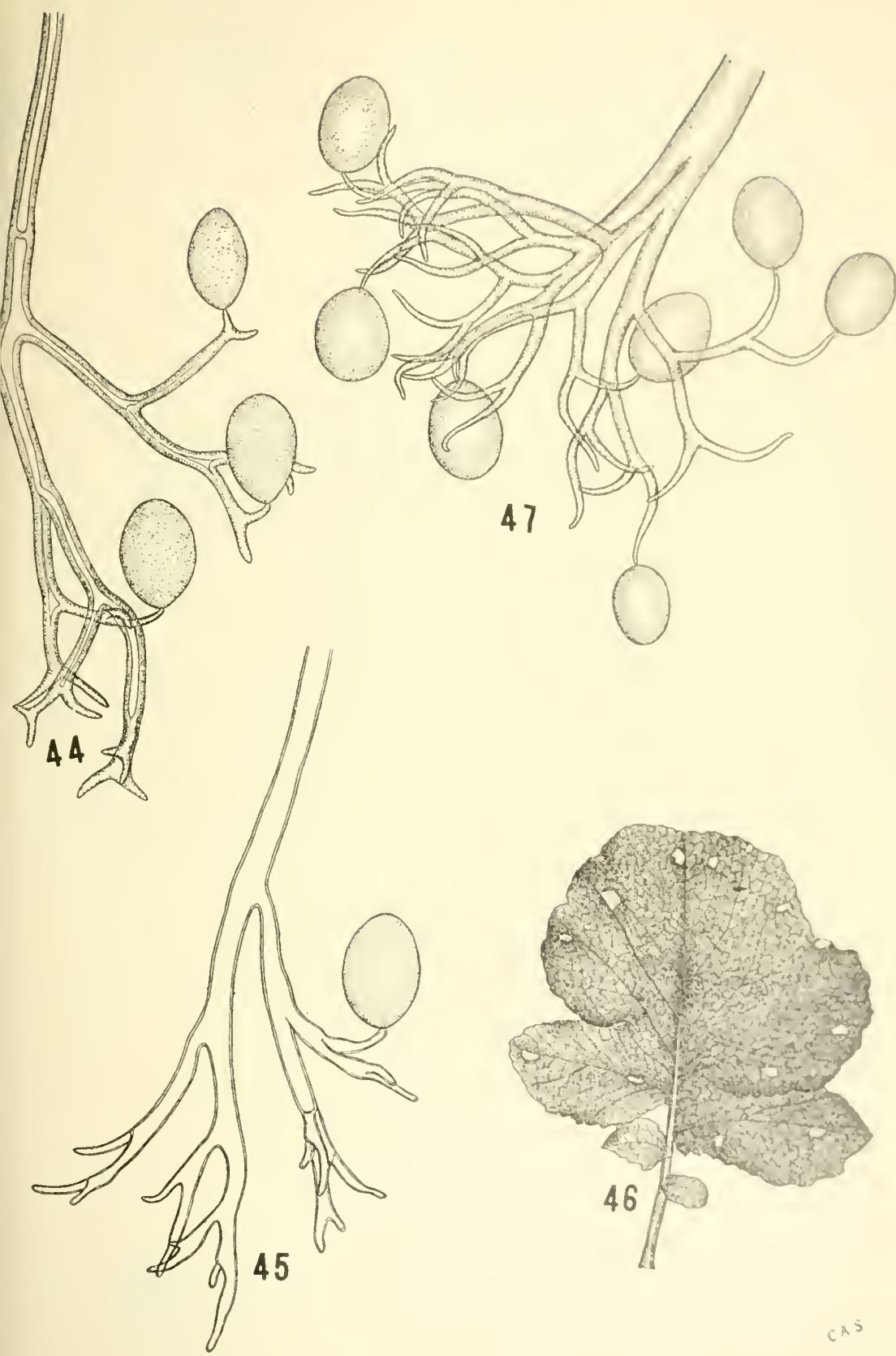


RHIZOPLS NigRICANs Ehr.--On sweet potatoes and other vegetables, and also on fruits in storage. Causes a soft rot. Luxuriant growth of white mycelium becoming almost black at maturity. Rhizoids abundant. Sporangiophores erect, fascicled and without septa. Sporangia almost spherical, blackish-olive. Columella hemispheric. Spores abundant, almost spherical, gray or brown, 11-1+ $\mu$.

48. Entire plant, 2/3. 49. Base of plant, 2/3. 50. Sporangia spores, 1/12.

Ruizopt's batatas Nakazawa. - On sweet potato. Causes a storage rot. Colonies snow-white, gradually becoming black. Sporangiophores in groups of $1-7$ and 100 to $500 \mathrm{~mm}$. in height, walls smooth and thick. Sprorangimm globular and 50-150 $\mu$ in diameter areraging 110 to $120 \mu$, white becoming black. Columella usually globular, 42-100 $\mu$. Spores irregular in form with a wrinkled outer wall, gray to dark brown in color, 3.5-5.2 x +.t-12.3 $\mu$. Inter callary cells variably formed, 12-60 $\mu$.

51. Sporangia spores, 1/12. 52. Stages in the formation of the zygospore, 2/3. 53. II all of immature zygospore, 1/12. 54. Wall of mature zygospore, 1/12. 55. Crystals from zygospores, $1 / 12$. 

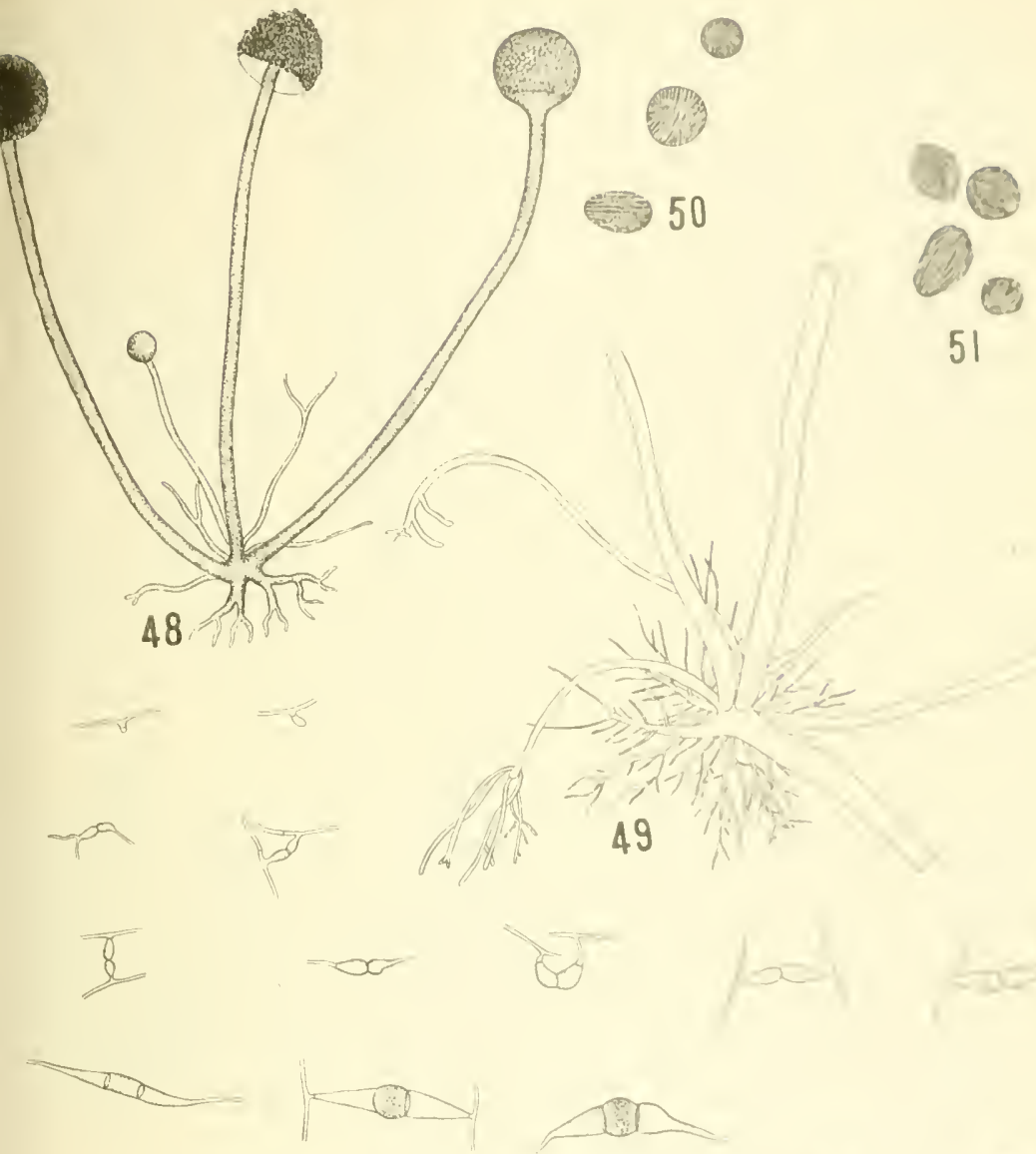

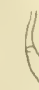
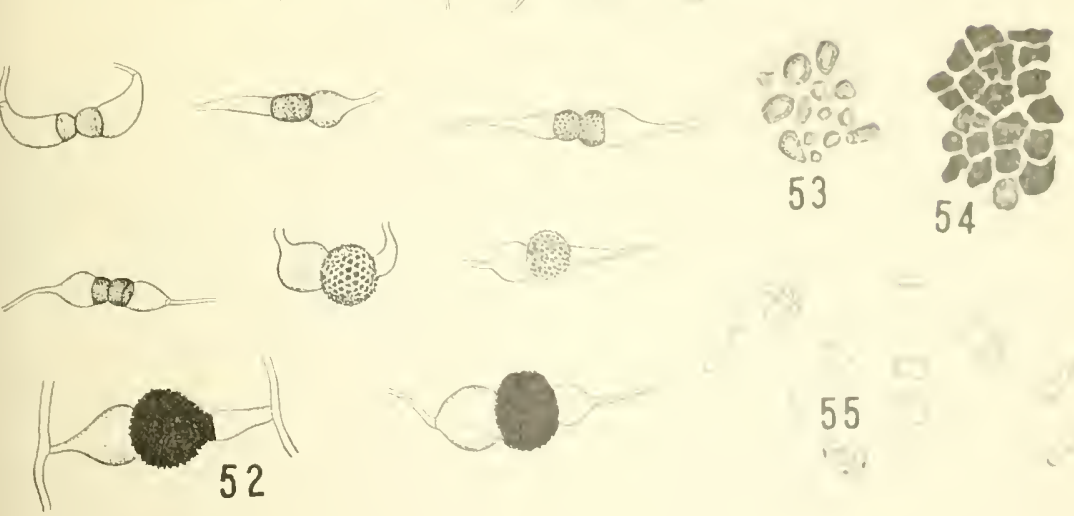
TAPhrina Aurea (Pers.) Fries.-On the leaves and inflorescence of the Populus. Causes a blistered appearance and covering of golden powder. Asci attenuated at base and immersed in the matrix, sometimes clavate, apex truncate, length 92-100 x 16-25 $\mu$; spores globular, numerous and variable in size.

56. Asci and ascospores, 1/12.

TAPHRINA Coerulescexs (D. \& M.) Tul.-Causes bluish blisters on the oak; asci elongated, broadly cylindrical, 55-78 x 18-24 $\mu$, spores breaking up into numerous small, condidia. Our material corresponds quite well with the original description (Ascomyces carulesiens).

57. Asci and ascospores, 1/12.

TAPHKina CERAsi (Fck.) Sad.-On the leaves of the cultivated cherry. Causes a deformation resulting in a witch's broom. Isci, $25-33 \times 6-9 \mu$; stalk cells, $10-17 \times 5-7 \mu$; asci round or oval and approximately $S$ in number.

58. Asci and ascospores, 1/12.

TAPIIRINA DEFormans ( Fcl.) Tul.-On the leaves, young fruit, twigs of the peach. Causes leaves to curl, frequently becoming pink or yellowish, and causes blisters on twigs and fruit. Asci are iormed just below the cuticle on the lower surface. They are cylindrical to slightly clavate, the ends rounded or truncate, 25-40 $\therefore$ $8-11 \mu$; the stalk cells, $6-8 \times 6-10 \mu$; frequently tapering towards the base; 4- -8 asco-spores are sub-globose or oval and measure $3-5 \mathrm{x}$ 4-6 $\mu$. They frequently go through a process of budding either before or after escaping, and produce conidia.

59. Infected peach leaf. 60. Asci and ascospores, 1/12.

Taplinina PRUNi (Fckl.) Tul.--On plums and cherries. Causes the "plum pockets," a bladdery-like growth of the fruits, and also attacks very young shoots. The asci are formed early in great numbers, breaking through and almost destroying the cuticle. Asci long and cylindrical, 30-60 × $8-15 \mu$; spores $S$, globose, 3.5-5 $\mu$.

61. Infected plum fruit. 62. Asci and ascospores, $1 / 12$. 
Sclerotinia fructigena (Pers.) Schr.-On the fruit, flowers, leaves and stems of peach, plum and cherry, and other drupaceous fruits. Causes a rotting of the fruit; dying of blossoms, young twigs and young shoots early in the season; and the formation of cankers on the twigs and smaller branches. The conidial stage (Monilia fructigena Pers., page 11t) is most conspicuous on fruits, many of which cling to the tree as mummies. The conidiophores and conidia in mass appear as a dense gray, brownish or ochraceous mold-like growth. The conidia measure about $20.9 \times 12.1 \mu$. The apothecia are rare in New Jersey. They are produced from the sclerotia on the fallen mummied fruits and measure about $0.5-3 \mathrm{~cm}$. in height; the stem is dark brown and the disk somewhat lighter and measures about 5-8 or occasionally as much as $15 \mathrm{~mm}$. in diameter; asci $125-215 \times 7-10 \mu$; ascospores ellipsoidal and $10-15 \times 5-8 \mu$.

63. Infected peach twig showing cankers. 64. Chain of conidia, 1/6. 65 . Same, 1/12. 66. Germinating conidia, 1/6, 1/12. 67. Apothecia from mummied fruit. 68. Ascus, 1/12.

Pseudopeziza medicagiris (Lib.) Sacc-On leaves of alfalfa. Causing irregularly distributed circular, yellowish to brown or black spot: which are visible on both surfaces of the leaf but most prominent on the upper; boundary slightly irregular and not sharply defined; varying from mere specks to about 1.5 to $2 \mathrm{~mm}$. in diameter. The spots appear early in the season but the apothecia are rather slow in forming and are usually most abundant in the fall. The apothecia are very small, amber or black shiny elevations. The asci are elongated and contain $\&$ spores; the paraphyes are filiform to clarate; the spores are hyaline, non-septate, elliptical and $8-11 x$ 4-6 $\mu$.

69. Infected leaf of alfalfa. 70. Surface view of the apothecia, 2/3. 71 . Cross-section of same, 2/3. 72. Asci, 1/12. 73. Ascospores, 1/12. 74. Paraphyses, $1 / 12$.

Pseudopeziza Ribis Kelb. (= Gloosporium ribis (Lib.) M. \& D. page 102).

Pseudopeziza salicis (Tul.) Pot. (= Gleosporium salicis West., page 102).

PSEUDOIEZIZA TRIFOlit (Yers.) Fckl. - On leaves of clover. Causes brown or yellowish-brown oval or irregular spots, sometimes with light centers, and about $0.5 \mathrm{~mm}$. in diameter. Conidia in numerous small, light-brown cup-shaped pycnidia, and are ovoidoblong and $5 \mu$, bi-guttulate; asci and ascospores similar to those of $P$. medicaginis and measure about $10-14 \times 5-6 \mu$. Ascocarps derelop on the dead spots; ascospores elliptic, 10-14 x 5-6 $\mu$.

75. Infected leaf of clover. 76. Asci and paraphyses, 1/12. 77. Ascospores, 1/12. 
Fabraea maculata (Lev.) Atk. (= Entomosporium maculatum Lev., page 94).

Rhytisma acerinum (Pers.) Fr. (= Melasmia acerina Lev., page 94).-On the leaves of the maple. Causes the so-called tar spots which are at first yellow, becoming thick and black. The conidiophores are short; conidia numerous, small, hyaline and 1 -celled; the apothecia ripen in the spring; they are arranged radially; the asci are $120-130 \times 9-10 \mu$ and the spores $65-80 \times 1.5-3 \mu$; the paraphyses numerous and incurved or hooked.

78. Infected leaf of maple. 79. Cross-section of apothecia showing asci, 2/3. 80. Ascus, 1/12. 81. Ascospores, 1/12.

LOPHODERMIUM BRACH YSPORUM Rost.-On the leaves of the pine. Asci cylindric, short-stalked, rounded apex, 120-20 x $25 \mu$, 8-spore; paraphyses bacillar with apices curved; spores oblong, hyaline, $28-30 \times 9-10 \mu$.

82. Infected needle of Pinus excelsit. 83. Cross-section of perithecium, 2/3. 84. Ascus and paraphyses, 1/6. 85. Ascus, 1/12. 86. Ascospores, 1/12.

Lophodermium pinastri (Schr.) Chev.-On pine needles, causing them to fall; conidia (formed the first year) are cylindrical, hyaline, continuous, $6-8 \times 1 \mu$. The ascocarps, formed the second year) are scattered, black, $1 \mathrm{~mm}$. or less in length; asci somewhat clavate and 8 -spored; ascospores cylindrical, nearly as long as the ascus, $90-120 \times 1.5 \mu$; paraphyses long, slender, and with curved tips.

87. Asci containing spores, 1/12. 88. Paraphyses, 1/12.

Thielavia Basicola (B. \& Br.) Zopf.-On the roots of alfalfa, sweet pea, horse-radish and other plants. Causes a root rot. Conidia hyaline, $10-20 \times 4-5 \mu$; chlamydospores in chains separating, short cylindrical, 5-8 × $12 \mu$; perithecia, $80-100 \mu$; asci ovate; ascospores non-septate, chocolate-colored.

89. Root of alfalfa showing cankers. 90. Mycelium, 1/6. 91. Chlamydospores, $1 / 12$. 
Penicilliuar luteuar Zuk. - On the roots of the sweet potato. Causes a rot. Produces abundant lemon-yellow mycelium through the potato; conidiophores floccose and spreading, 20-100 $\mu$ (mostly $30-60$ by $3 \mu$ ) : conidia elliptical or fusiform, greenish, $2.4 \times 2.3 \mu$; perithecia smooth, brown and finally brick-red. Asci small, numerous, globular to ovate and containing 8 spores. Spores, ovate to ovate-oblong and ridged, at first hyaline, becoming light brown. All attempts to germinate these spores failed.

92. Germinating conidia, conidiophore and spores in hanging drop culture, 1/6. 93. Germinating spores, 1/6. 94. Pcrithecium, 2/3. 95. Asci and ascospores, $1 / 12$.

Erysiphe cichoracearum D. C. (= Oidium ambrosice Thüm, page 116).-On green parts of a number of plants. Causes whitish, sometimes pinkish, downy growth which is usually evanescent. Conidia small, white, elliptic, $4-5 \times 7-5.3 \mu$. Perithecia grouped or scattered and $80-140$, sometimes $180 \mu$, in diameter. Appendages brown and variable in number and size. Asci 4 to 36 , usually 10-15, and variable in size and shape, ovate or subcylindrical to broadly ovate stalked, $58-90 \times 30-35 \mu$. Ascospores 2, occasionally $3,20-28 \times 12-30 \mu$.

96. Perithecium, 1/6. 97. Asci, 1/12. 98. Ascospores, 1/12.

Erysiphe graminis D. C. (= Oidium monilioides Lk., page 116).- On the leaves and sometimes on other parts of wheat. barley and other cereals. Causes white, grayish or brownish, moldy patches on affected parts. Conidia ovoid, whitish, 25-30 8 8-10 $\mu$. Perithecia 135-280 $\mu$, usually about $200 \mu$, scattered or grouped. Asci 9-30, cylindric or ovate-long, more or less pedicilate, $70-180 \mathrm{x}$ 25-40 $\mu$. Spores 8 , occasionally 4, 20-23 x 10-13 $\mu$, and seldom maturing on living host.

99. Conidiophore and conidia, 1/12. 100. Immature ascus. 


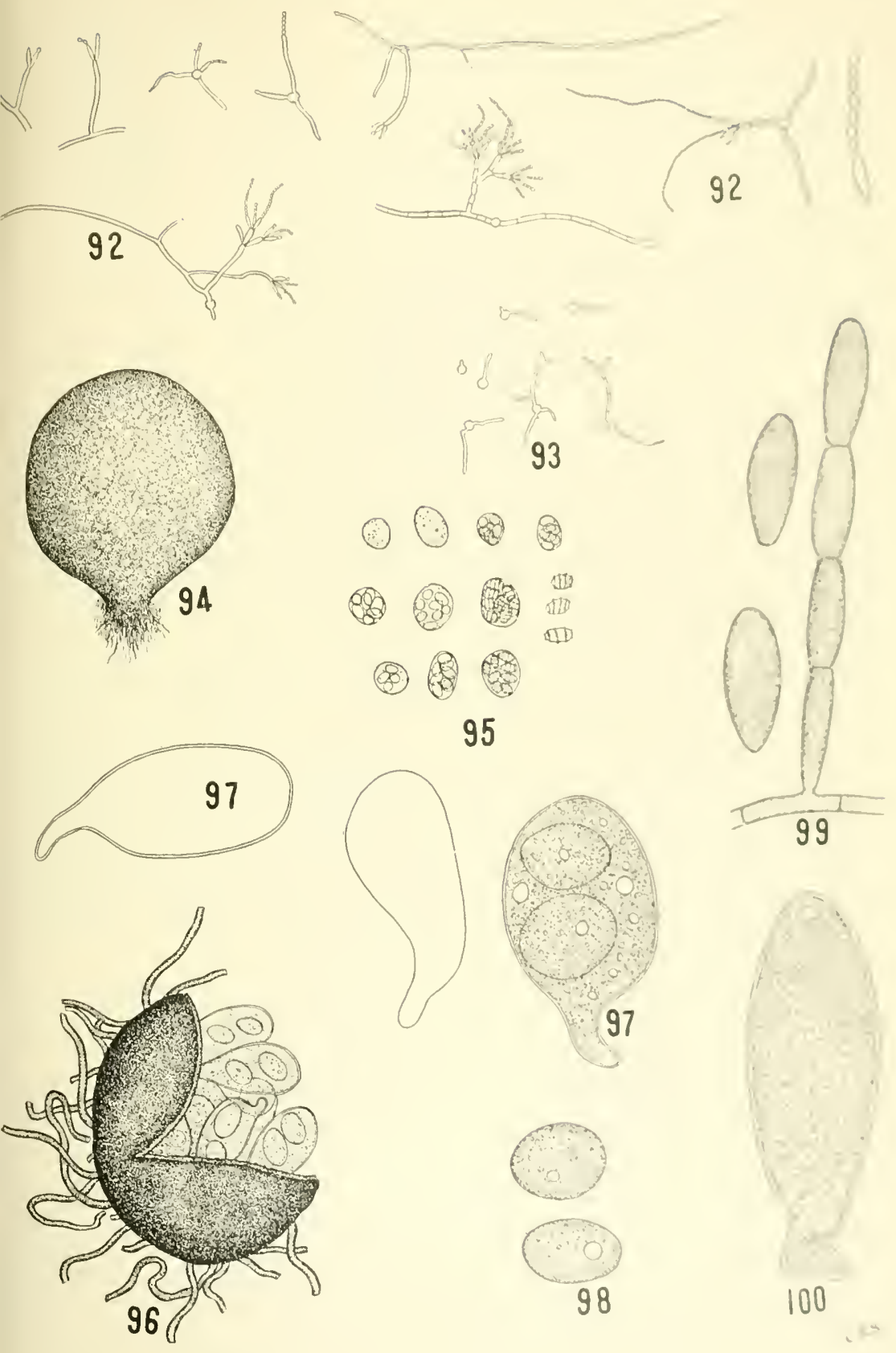


Microspitara alxi (IVal.) Wint.-- On leaves of lilac, alders, naks and many other plants. Producing persistent or non-persistent mycelium. Perithecium scattered or grouped, and variable in size, 66-110 $\mu$, occasionally $135 \mu$. Appendages irregular, 3-6 times dichotomously branched, tips of final branches recurved. Asci 3-8, ovate or ovate-globose, $42-70 \times 32.50 \mu$, usually with short stalks; 4-8 spores, $18-23 \times 10-12 \mu$.

101. Perithecium, 1/6. 102. Tips of appendages, 1/12. 103. Immature ascus and spores, 1/12. 104. Mature ascus, 1/12. 105. Ascospores, 1/12.

Piryllactinia corylea (Pers.) Karst.-On the leaves of oaks, alders, and many other plants. Produces evanescent, sometimes persistent mycelium on the under and sometimes on the upper surface of the leaves. Perithecia scattered or grouped, 140-270 $\mu$, rarely $350 \mu$; appendages $5-18$, equatorial. Asci 5-45, subcylindrical to ovate-oblong, $60-105 \times 25-40 \mu$; more or less stalked, 2 , rarely 3 cpores, $30-42 \times 16-25 \mu$.

106. Perithecium, 2/3. 107. Appendage 1/6. 108. Ascus, 1/12. 
Parasitic Fungi of New Jersey

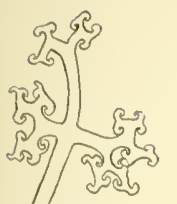

102

se ges
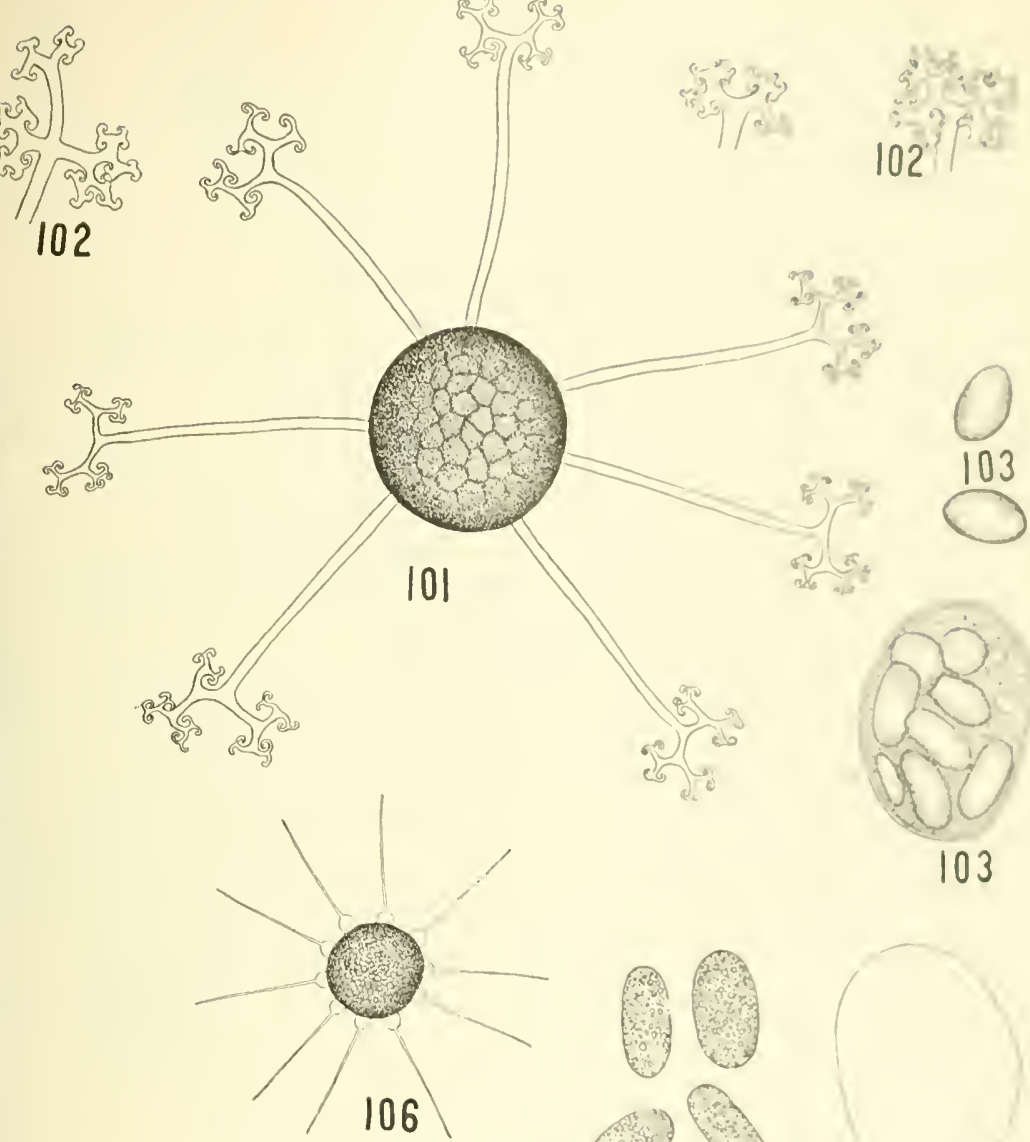

107

104
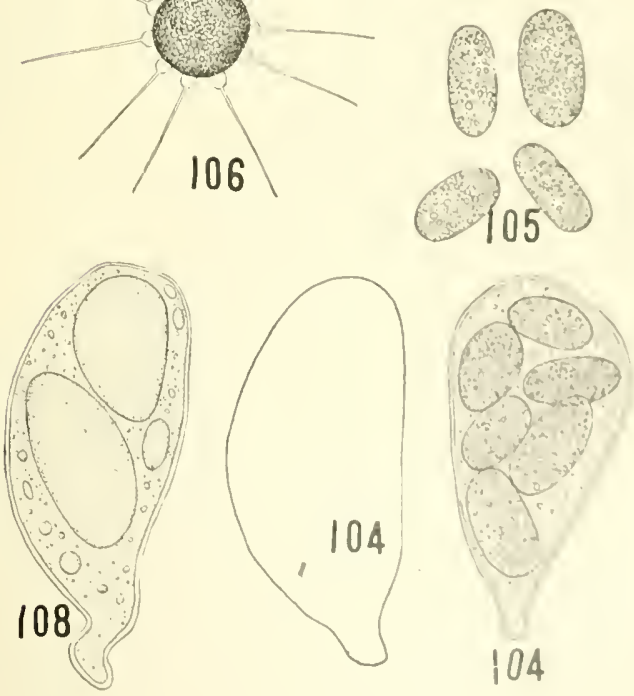
Podosphaera oxyacaxthe (D. C.) de Bary (= Oidium crataegi Grogn., page 116).--On leaves and other green parts of cherry, cratægus and other pomaceous and drupaceous fruits. Produces meager but rather persistent mycelium. Perithecia scattered or grouped, 64-90 $\mu$; appendages arranged more or less equatorially, variatle in number (4-30) and length, dichotomously branching, each branch more or less knob-shaped. Asci broadly obovate or subglobose, $58-90 \times 45-75 \mu$; spores 8 , rarely $6,18-30 \times 10-17 \mu$.

109. Perithecium, 1/6. 110. Immature asci, 1/12. 111. Mature ascus, 1/12. 112. Ascospores, $1 / 12$. 


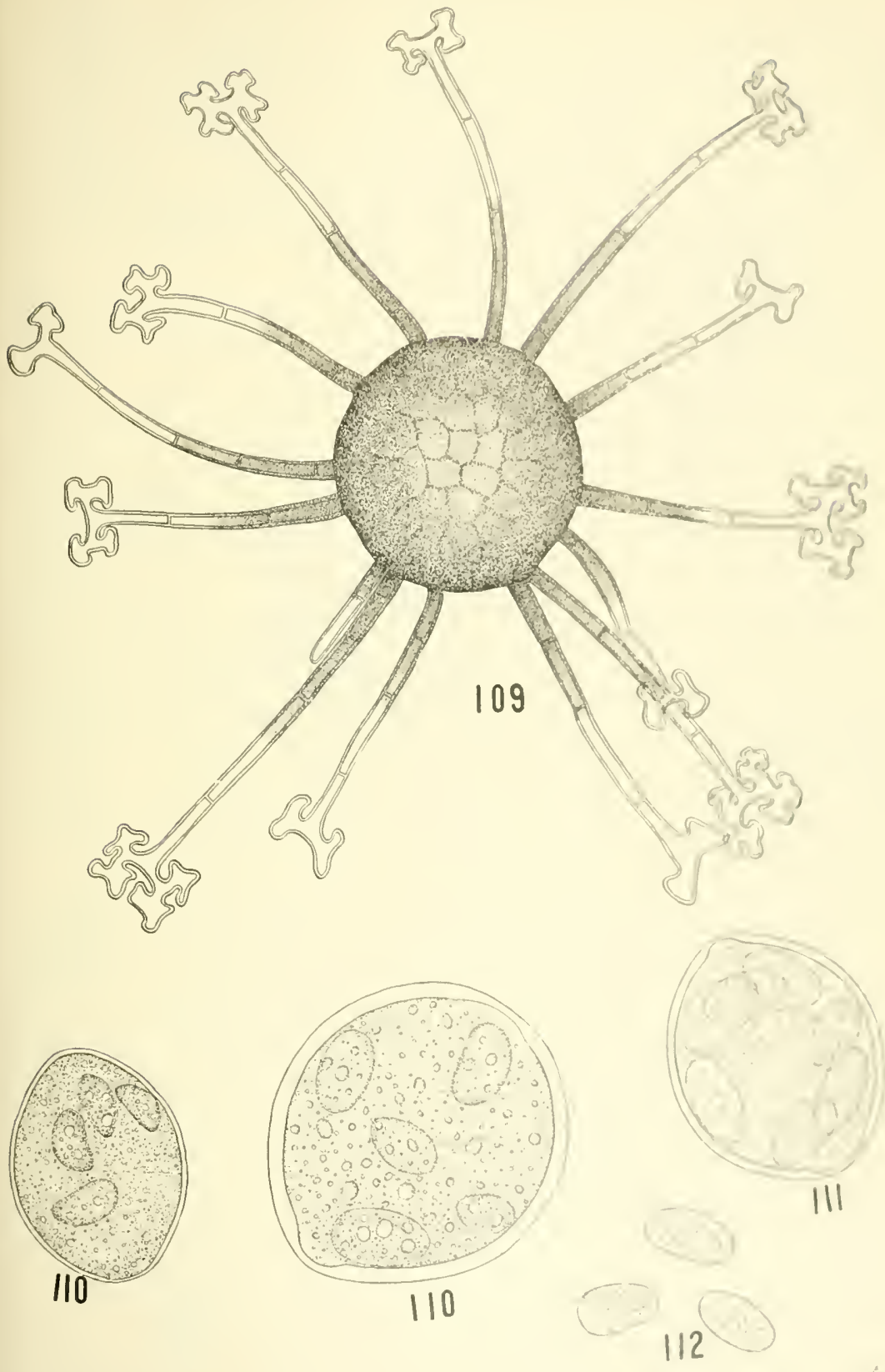

(?) 
Spherotheca humili var. fuliginea (Schl.) Sal. (= Oidium fragariae, page 116).- On flowers, leaves and stems of hops.* Causes circular, white, powdery spots which enlarge and unite, forming large irregular areas. Most severe on the young tender parts. White downy growth disappears with age leaving brown spots. The perithecia are formed in these brown areas. Perithecia not more than $50 \mu$ in diameter, appendages short and light brown. Asci broadly elliptic to sub-globose and containing $S$ spores each. Ascospores $20-25 \times 12-18 \mu$.

113. Conidiophore and spores, 1/6. 114. Conidia, 1/12. 115. Perithecia, 1/6. 116. Ascus, 1/12. 117. Ascopores, 1/12.

Spit Ærotheca panNosa (Wal.) Lev. (= Oidium leucoconium Desm., page 116).-On the green parts of roses and peaches. Causes a stunting of young growths and prevents normal development of the flower. Affected parts are covered with a dense satiny growth of mycelium which is more persistent than S. humili, shiny white, finally becomes gray, buff or brownish. Conidia ovoid hyaline, $20-30 \times 13-16 \mu$, and borne on short conidiophores. Perithecia surrounded by mass of mycelium. Appendages few, sometimes obsolete, very short tortuose, pale brown, septate globose to pyriform, and about 85-120 (usually 100) $\mu$. Asci broadly-oblong to almost spherical, 88-115 $\mu$, averaging $100 \times 60-75 \mu$. Ascospores $20-27 \times$ 12-15 $\mu$. Conidia common on rose but perithecia are rare.

11S. Conidiophores 1/6. 119. Spores, 1/12. 120. Perithecium, 1/6. 121. Ascus, 1/12. 122. Ascospore, 1/12.

UnCinula NeCATOR (Schw.) Burr. (= Oidium tuckeri Berk., page 116).--On the young leaves, young shoots and fruits of grape, ampelopsis, etc. Produces a luxuriant, persistent growth of mycelium. Conidia elliptic, oblong or obtusely rounded, hyaline, 25-30 $\mathrm{x}$ 15-17 $\mu$. Perithecia on both leaves and fruit more or less scattered, $70-128 \mu$; appendages septate, 7 to 30 and rarely 40 in length;

*Also on strawberry, dandelion and other hosts. 
I'ARasitic Fungh of New Jersey

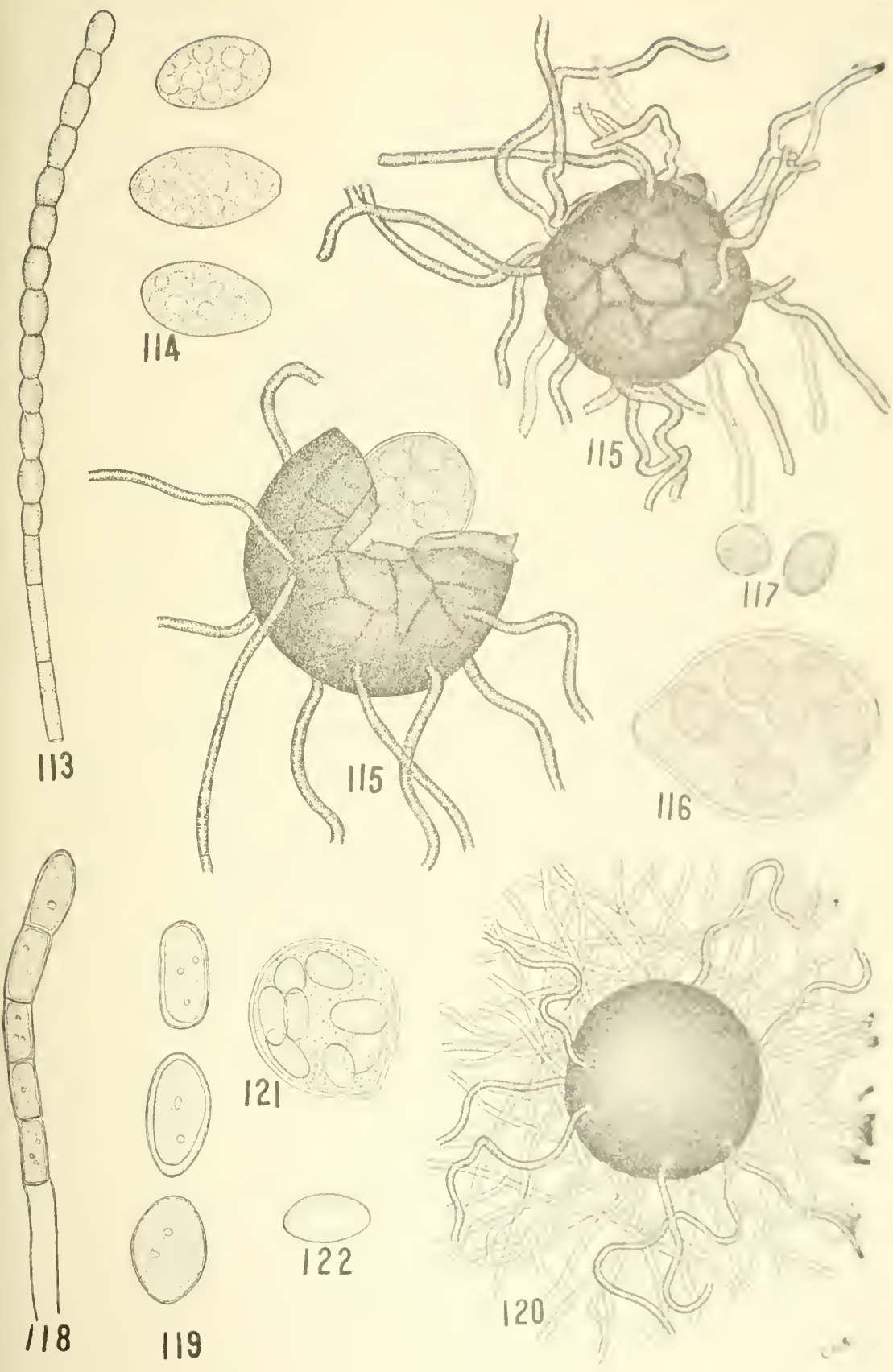


asci 4 to 6 or sometimes 9, broadly-ovate, ovate-oblong or subglobose and without stalk, $5-60 \times 30-40 \mu$; spores $4-7,18-25 \times$ 10-12 $\mu$.

123. Perithecium, $1 / 6$.

Diplocarpon rose Wolf. (= Actinonema rosa,* page 84).

Dimerosporium collinsil (Schw.) Thüm.-On green parts of Amelanchier canadensis and A. alnifolia. Causes witches' brooms and forms a dense mass of brownish, black, septate mycelium on the under surface of the leaves, frequently concealing all but the midrib and most prominent veins. Conidiospores brown, more or less elliptical, 9-13 $\times 5-7 \mu$. Perithecia in masses on under surface of leaf, occasionally scattered on upper surface, black, globose, or polyhedral, with beak which falls away leaving circular ostiola, 150$190 \mu$; asci cylindric-clavate, 8-spored, 45-60 × $10 \mu$; ascospores hyaline to pale yellow, ovoid, unequally septate, the septum near the base of the spores, $12-15 \times 3-5 \mu$.

124. Infected leaf of Amelanchier conadensis (under surface). 126. Conidiospores, 1/6, 1/12. 126. Conidiospores, 1/12. 127. Perithecia, 2/3. 12子. Ascus, 1/12. 129. Ascospores, 1/12.

Nectria cinnabarina (Tode) Fr. (= Tubercularia vulgaris Tode, page 144).-On woody parts of currants, mulberry, Norway maple and many other plants. Primarily a saprophyte but sometimes parasitic, causing cankers on woody parts and death. When parasitic the cankers always originate with a wound. Stroma breaks through the bark, the tubercularia stage pinkish, becoming yellowish-red and a dark red with age, $1.2 \mathrm{~mm}$. high and broad; conidiophores in tubercular masses, each $50-100 \mu$ long; conidia or short, lateral branches, elliptic, hyaline, 4-6 $\times 2 \mu$. Perithecia massed and frequently concealing the stroma, each perithecium nearly globose with prominent ostiolum, becoming slightly collapsed, cinnabar red, becoming darker with age, sometimes black, 374-400 $\mu$; asci clavate, 50-90 $\times$ 7-12 $\mu$, and 8-spored; spores mostly 2-septate, elliptical, elongate, 3 or 4 times as long as broad, obtuse ends, 1-septate, hyaline, usually slightly curved, $12-20 \times 4-6 \mu$. Paraphyses delicate.

130. Conidia (Tubcrcularia stage), 1/12. 131. Cross-section through stroma and perithecia. 132. Ascus, 1/12. 133. Ascospores, 1/12.

\footnotetext{
*Syn. Marssonina rosa (Lib.) Trail-Ann. Mycol. v. 10, p. 146 (1912).

*Referred to genus Apiosporina by v. Hoehnel (Fragm. zur Mykol., No. 506).
} 
Parasitic Fungt of New Jersey
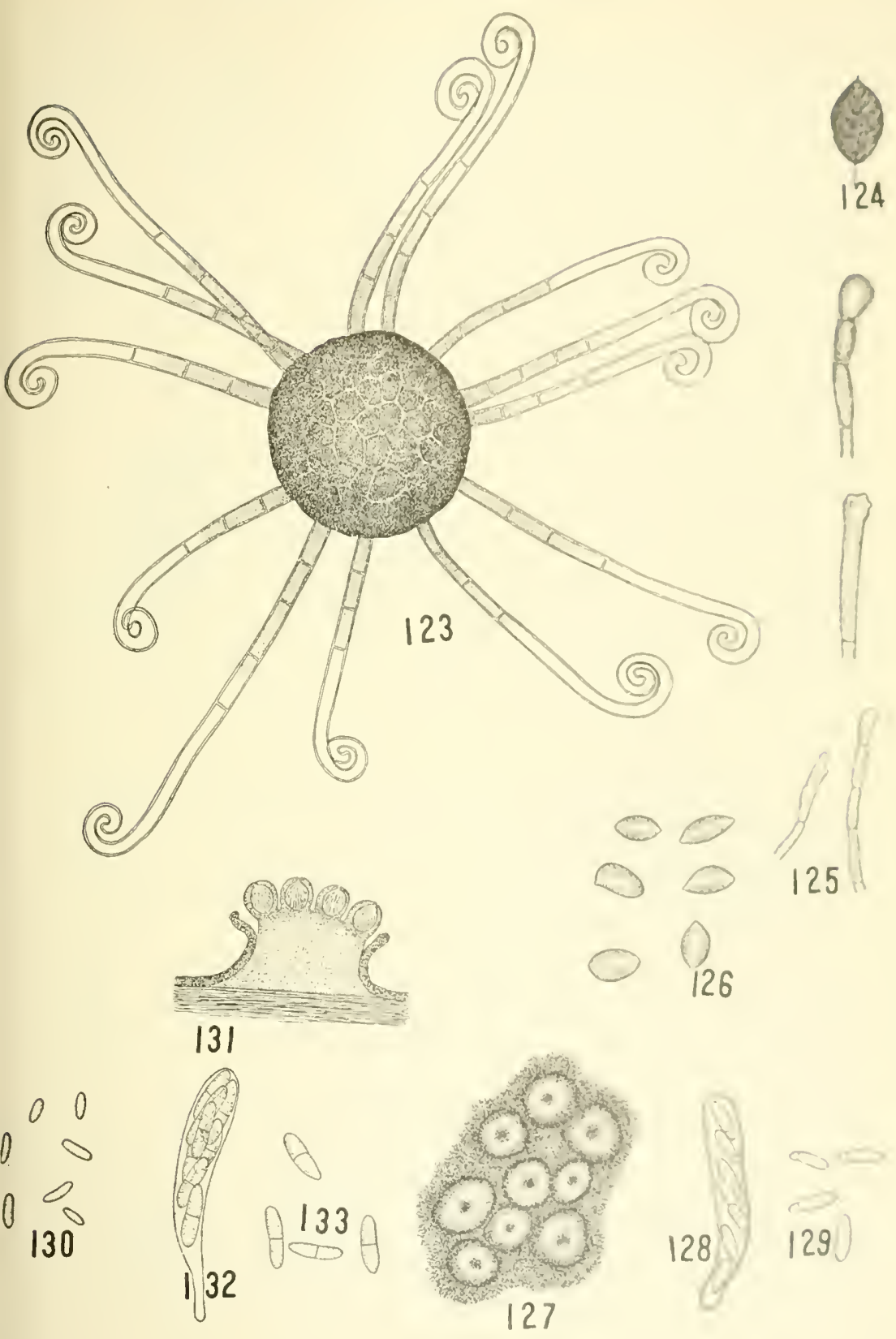
Nectria iponioez Hals.-On sweet potatoes. Causes a storage rot but is saprophytic rather than parasitic. Conidia (Fusarium sp.) falcate 1 to 6-celled; perithecia in tufts, globose or somewhat conical, red; asci clavate, 8-spored; spores elliptical, 1-septate, slightly constricted, hyaline. The ascigerous stage was produced from single conidiospore culture.

134. Mycelium, conidiophores and spores 1/6. 135. Conidia, 1/12. 136. Various formations of chlamydospores, 1/6, 1/12. 137. Germinating chlamydospores, 1/12. 138. Immature perithecium, 2/3. 139. More advanced stage of same, 2/3. 140. Tip of mature perithecium, 1/6. 141. Asci, 2/3. 142. Same, 1/6. 143. Ascospores, 1/6. 144. Germinating ascospores, 1/6.

Chromocrea ceranica (E. \& E.) Seaver.-On Ganoderma tsuga. Scaver (Mycologia, v. 2, p. 59, 1910) describes it as follows:

"Stromata appearing first as a speck of white tomentum, with a brick-red spot appearing in the center, finally becoming fleshy, rather thick and entirely brick-red without, and white within, subpatellate, convex, becoming wrinkled when dry, punctuate with the necks of the slightly protruding perithecia finally dusted over with the greenish spores; asci cylindrical, becoming 16-spored by the breaking of each original spore into 2 subglobose cells; spores about $4 \mu$ in diameter, the lower of each pair a little larger than the upper."

This description from material growing on decaying limb of Juniperus. Our specimen was without doubt parasitic. The fungus determined by Dr. F. J. Seaver and the host by Dr. IV. A. Murrill.

145. Cross-section of stroma, 2/3. 146. Same, 1/6. 147. Ascus, 1/12. 148. Ascospores, 1/12.

Balansia mypoxylon (Pk.) Atk.-On the grasses. Seaver (Mycologia, r. 3, p. 223, 1911) describes this species as follows: "Sclerotia formed in the fruiting axis of the host, curved and irregular, $1 \mathrm{~cm}$. or more in length, grayish or blackish; stromata black, prominent, pulvinate or subhemispheric, $1-5 \mathrm{~mm}$. in diameter, several springing from the same sclerotium minutely roughened by the slightly protruding perithecia, perithecia immersed; asci cylindric, with a pedicel at the base, as much as $20 \mu$ in length; spores 1 mic thick at maturity breaking into segments $3-4 \mu$ long.

149. Infected grass. 150. Cross-section of stroma, 2/3. 151. Same, 1/6. 152. Ascus containing spores, $1 / 12$. 
Triphodum typhinum (Pers.) Seaver.--On grasses. Prevents flowering. Seaver (Mycologia, v. 2, p. 86, 1910) describes this species as follows: "Stroma effused, subfleshy, at first pale, becoming bright orange, forming sheaths $2-5 \mathrm{~cm}$. in length, about the stems of various grasses; conidia elliptical, hyaline, 4-5 $\times 3 \mu$; perithecia thickly scattered, partially to entirely immersed, soft membranaceous, similar in color to the stroma, with rather prominent ostiolum; asci cylindrical, very long, 8-spored; spores nearly as long as the ascus, in a close fascicle, about $2 \mu$ in diameter, many septate."

153. Infected grass. 154. Longitudinal section of same through stroma. 155. Ascus containing spores, $1 / 12$.

Cordyceps agariciformia (Bolt.) Seaver. - On Elaphomyces. Seaver (Mycologia, v. 3, p. 217, 1911) describes this species as follows: "Stromata occurring singly or in clusters of several each, $3-8 \mathrm{~cm}$. high, consisting of a sterile stem and an oroid or capitate, fertile head. stem uniform in thickness or a little thicker below, fibrous yellowish, becoming nearly black (in dried specimens), smooth head ovoid agariciform, about $1 \mathrm{~cm}$. in diameter, reddish brown becoming nearly black, roughened by the slightly protruding necks of the perithica, perithecia immersed, but prominent, asci very long, cylindric, about $15 \mu$ thick, spores, filiform, nearly as long as the ascus, finally breaking into segments, subhyaline, fusoid or oblong ellipsoid, with the ends rounded, $20-40 \times 4-5 \mu$."

156. Mature plant parasitic on another fungus. 157. Part of ascus, 1/12. 158. Ascospores, 1/12.

Cordyceps clavulata Schw.-On the dead scale insects. Seaver (Mycologia, r. 3, p. 314, 1911) describes this species as follows: "Sclerotia formed in the bodies of dead scale insects; stromata slender, clavate, at first sterile, at maturity with an enlarged clavate fertile head and a slender, sterile stem, the whole $3-4 \mathrm{~mm}$. high, 3-8 springing from a single sclerotium; stem slender, $1-2 \mathrm{~mm}$. long, grayish cinereous, head thicker, darker in color and strongly roughened by the protruding necks of the perithecia: asci clavate, broader near the middle, $8-100 \times 8-10 \mu$; spores much elongate, subfiliform, broader near the base and tapering toward either end, 7-8 septate about 50-80 $\mu$ long, $3 \mu$ thick at the broadest point, hyaline.'

159. Twig bearing infected scale insects. 160. Ascus, 1/12. 161. Ascospores, $1 / 12$. 
Parasitic Fungi of New Jersey

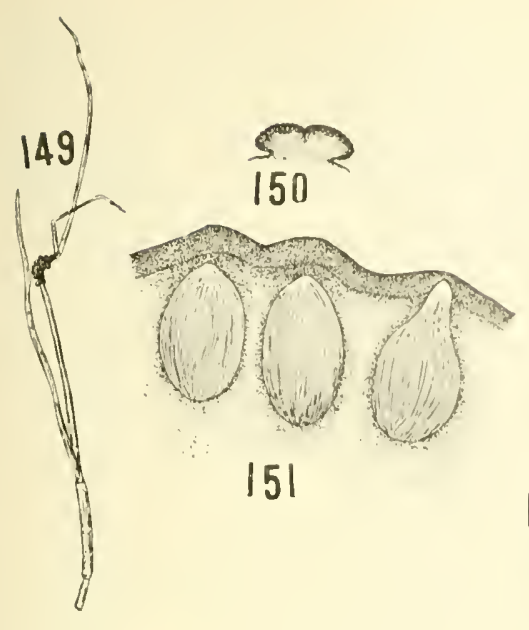

152
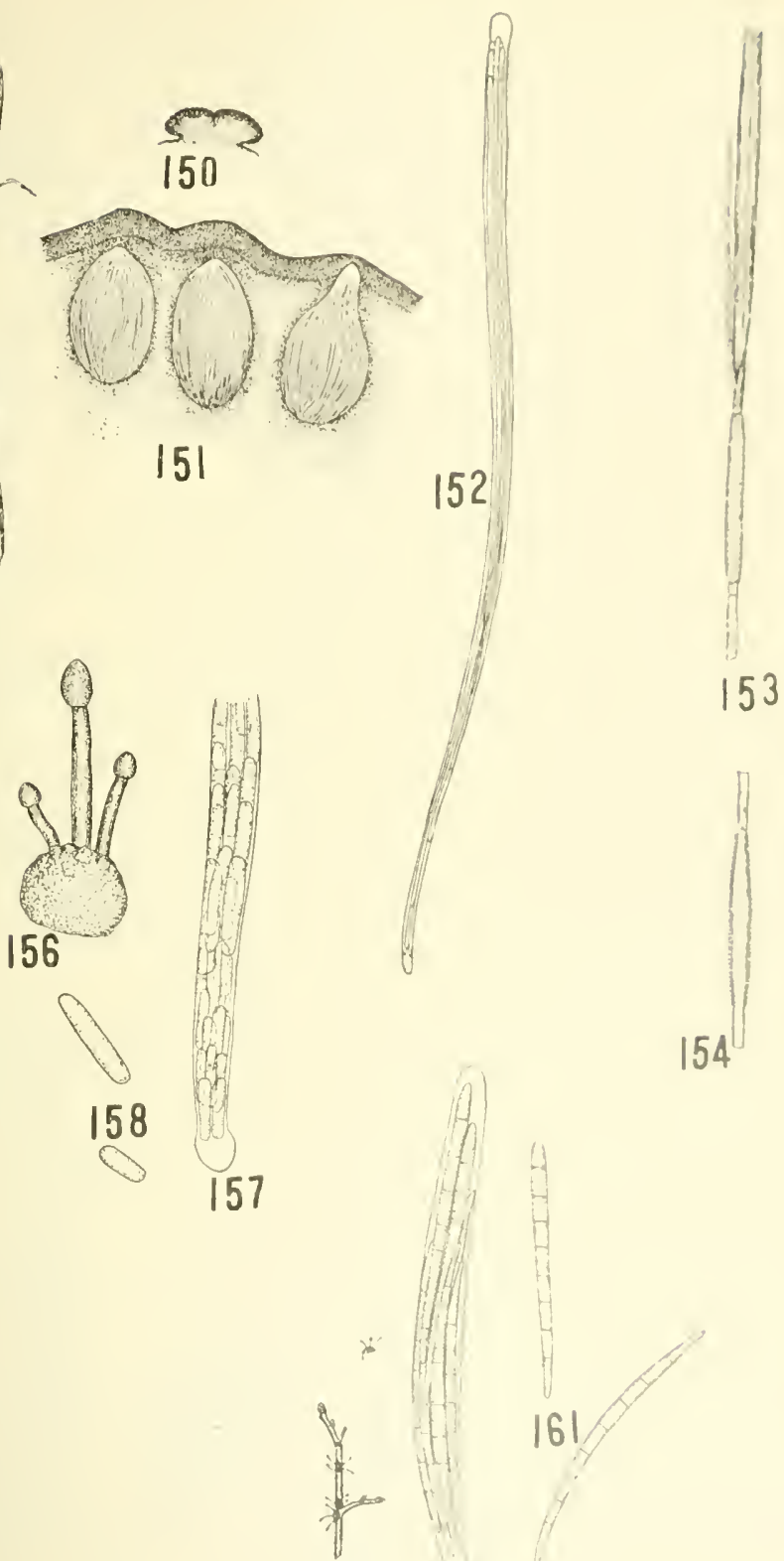

155

159

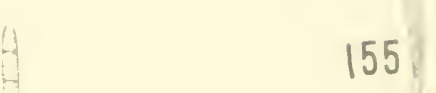

160 
CORDiCers in ILITARIS (L.) Link--On buried or partially buried insect pupa. Seaver (Mycologia, v. 3, p. 209, 1911) describes this species as follows: "Sclerotia formed in the pupæ of insects, compact, white, conidial stage (Isaria) rising from the sclerotium, consisting of a slender stalk, and a white, floccose, feather-like head; stromata at maturity consisting of a sterile stem and fertile, clavate head, usually a simple but more rarely forked or branched, the whole often attaining a height of $4-5 \mathrm{~cm}$. but often much shorter, bright-orange; p-rithecia thickly scattered or crowded, for the most part with the necks protruding, or superficial (especially in weathered specimens) ; asci cylindric; spores filiform, nearly as long as the ascus, many-septate, breaking apart at the septa, giving rise to numerous subellipsoid segments $2-3 \mu$ long."

162. Infected larva and mature plant. 163. Part of ascus containing spore, $1 / 12$.

Cordyceps sphingun (Schw.) B. \& C.-On dead insect larva within the cocoon. Seaver (Mycologia, v. 3, p. 216, 1911) describes this as follows: "Stronata numerous, as many as thirty often springing from a single sclerotium, very slender and thread-like, about $5 \mathrm{~cm}$. high and $1 \mathrm{~mm}$. in thickness, cinerous, smooth or slightly pruinose. enlarged at the base, more or less bent above; perithecia subsuperficial, subconic 25-150 × 200-225 $\mu$, brownish, asci elongate, cylindric; spores filiform, as long as the ascus, about $2 \mu$ thick."

164. Infected larva in cocoon and mature plant. 165. Ascus containing spores, $1 / 12$.

Plowrightia morbosa (Schw.) Sacc. - On the stems of plums and cherries. Causes black, unsightly, wart-like enlargements of the affected parts and frequently results in death. The young knots are formed in the spring and are greenish and bear the conidiophores and conidia (Cladosporium). The conidiophores are erect, simple, septate and 40-60 × 4-5 $\mu$; the conidia are light brown, obovate, unicellular and about $6-8 \times 2-5 \mu$. The mature knots are black, tubercular, conspicuous, extremely variable in size, the perithecia are formed late in the summer or early winter, scattered. sometimes suppressed; asci about $120 \mu$ in length, containing 8 spores which are obliquely uniseriate, and $16-20 \times 8-1 \mu$; paraphyses present. (See Ann. Mycol., v. 13, p. 663, 1915.)

166. Infected cherry twigs showing conidiophore stage. 167. Conidiophores and spores, 1/12. 168. Infected cherry twig in advanced stage. 169. Crosssection of stroma showing perithecia. 170. Asci and ascospores, 1/12. 

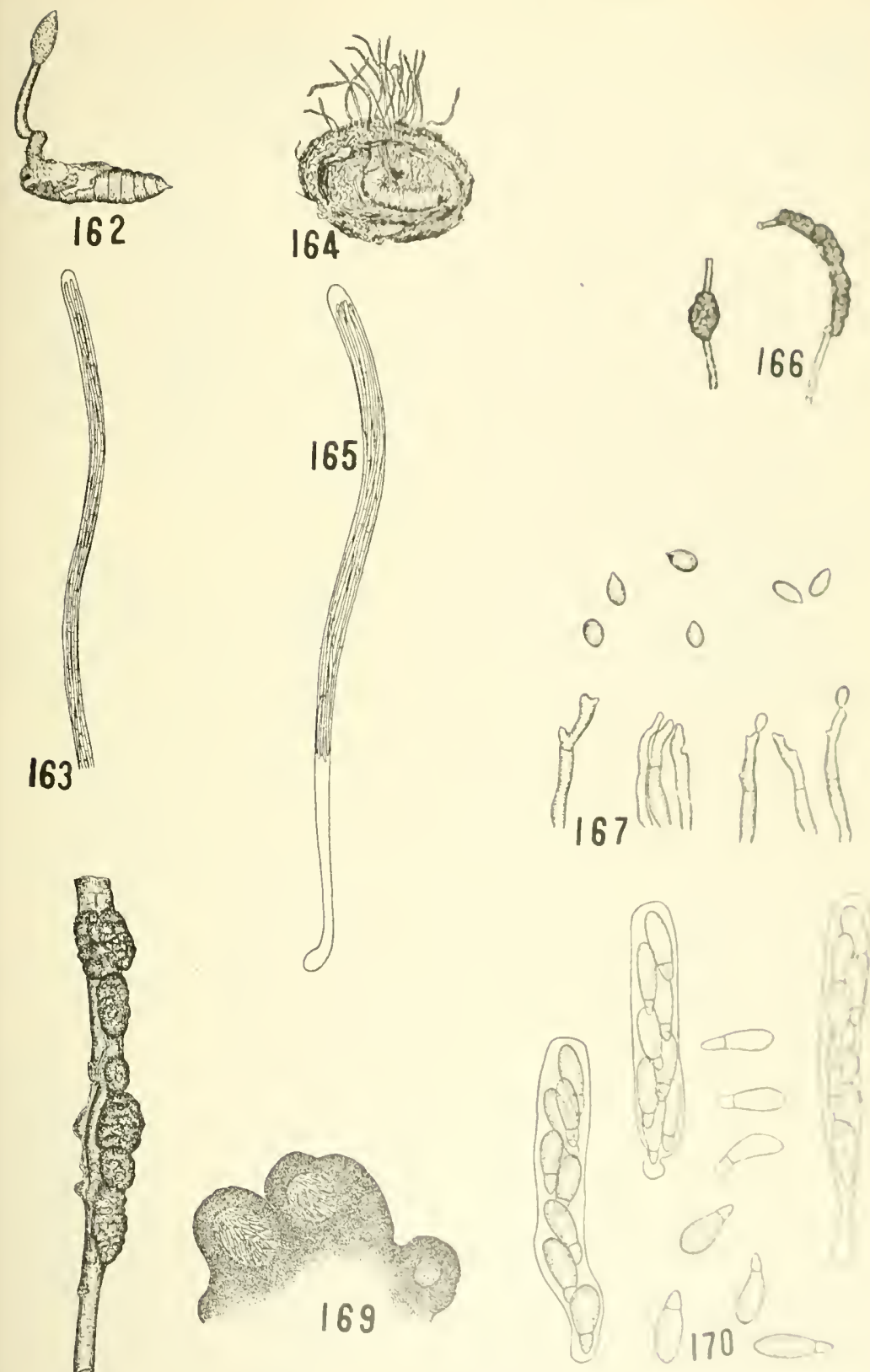

168 
Phyllachora graminis (Pers.) Fcl.-On leaves of grasses and sedges. Stroma variable in size but causing small, conspicuous black spots. Conidia unknown. Perithecia immersed and ostiolate; asci cylindric and with short pedicles, $70-80 \times 7-8 \mu$; ascospores, hyaline, ovoid, obliquely uniseriate, $8-12 \times 4-5 \mu$; paraphyses filiform.

171. Infected blade of grass. 172. Cross-section of stroma showing peri. thecia, 2/3. 173. Ascus. 17. Ascospores, 1/12.

Phyllachora trifolit (Pers.) Fcl. (= Polythrincium trifolii Kze., page 122). - On the leaves of clovers. Causes small black spots of $1 \mathrm{~mm}$. or less. Conidiophores (Polythrincium trifolii) wavy, erect, simple and black; conidia obovate, 1-septate slightly constricted, pale, olivaceous, 20-24 $\times 9-10 \mu$; ascospore stage rare; asci $8-10 \times 5-6 \mu$.

175. Infected clover leaf. 176. Conidiophores and conidia, 1/12. 177. Conidia, 1/12.

Acanthorynchus vaccisin Shear. - On the cranberry. Mycelium in leaves and fruit without necessarily producing a rot. Rot frequently appearing after putting fruit in storage. Rot light brown to chocolate-colored, more solid than the scald rot. Perithecia scattered on decaying leaves, never on green leaves, rarely found on fruit, subglobose to flask-shaped, $120-200 \mu$ in diameter, submembraneous, the stout neck projecting and more or less covered with spines measuring $50-70 \times 8.9 \mu$; asci subelliptic to clavate, pale, brownish-yellow, surrounded by a mucilaginous layer of protoplasm, $2+-32 \times 12-18 \mu$.

178. Perithecium from culture, 2/3. 179. Tips of perithecia, 2/3. 180. Immature ascus, ascospores and paraphy'ses, 1/6. 181. Mature ascus, 1/12. 182. Mature ascospores, 1/12.

Guignardia asculi* (Pk.) Stewart (= Phyllosticta pavice Desm., page 68).-On the leaves and sometimes on the immature fruits of horse-chestnut (Aesculus hippocastanum) and the buckeye ( 1 e. glabra). Causes large, irregular dry brown or dark red blotches with indefinite yellow borders. Pycnidia globose, black, 90-175 $\mu$; conidia oval 10-16 $\times 6.5-10 \mu$; spermagonia with minute hyaline spores; asci clarate $54-70 \times 15-17 \mu$ or larger when wet; ascospores subelliptical, uninucleate, granular, 12-18 x 7-9 $\mu$.

183. Pycnidium, 2/3. 184. Conidia, 1/12. 185. Ascus, 1/12. 186. Ascospores, $1 / 12$.

\footnotetext{
* Syn. Lastadia cesculi.
} 
Parasitic fungi of Nell Jerstig

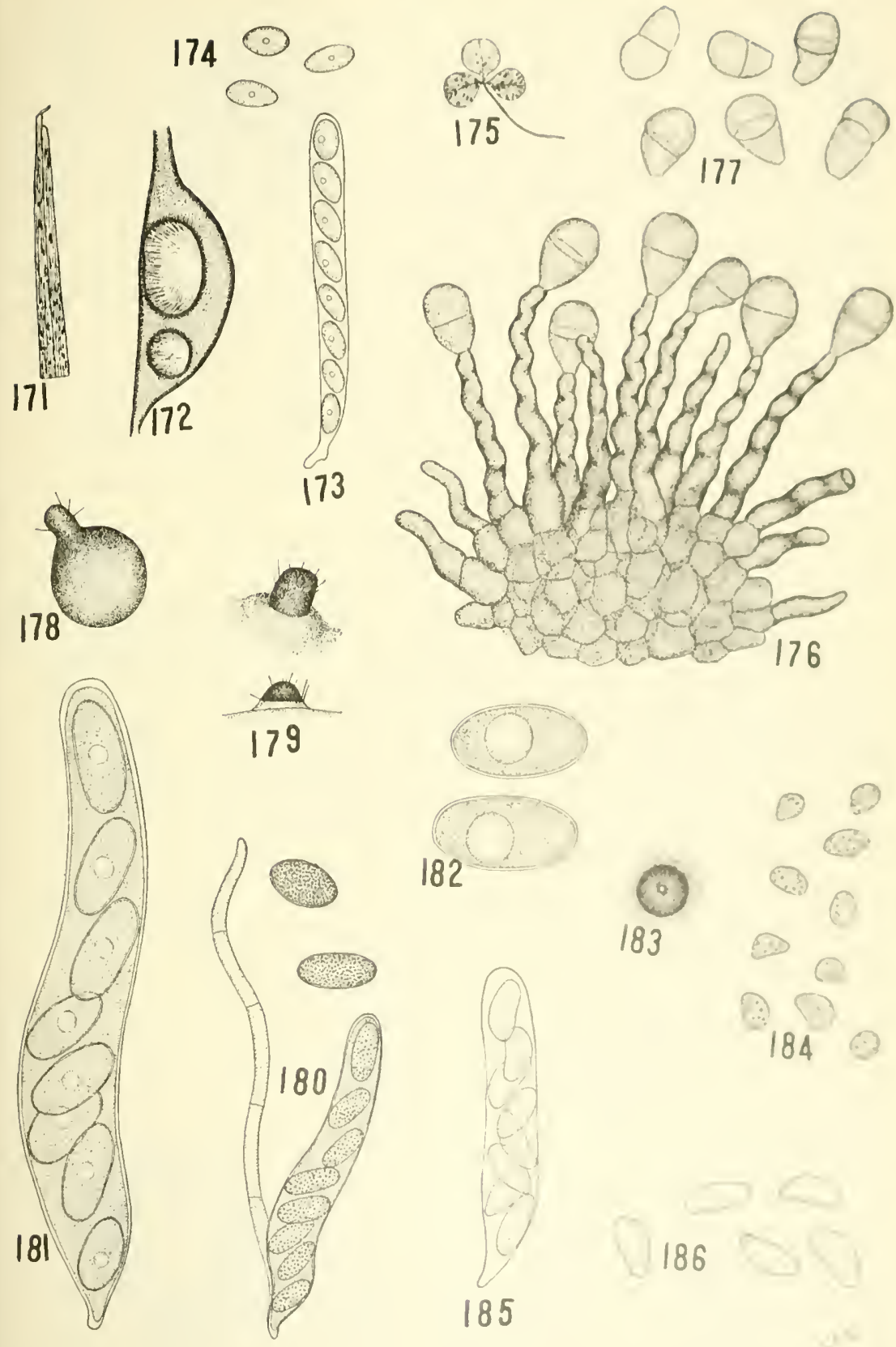


Guignardia bidwelli (E.) V. \& R. - On berries, leaves and stem of grapes. Causes rotting of the fruit, spots on leaves, stems and tendrils. The conidia (Phyllosticta labrusca Thüm., page 66) on leaves (Phoma uvicola, page 72), on stems and tendrils, borne in numerous black, papillæ-like pycnidia $180 \times 180 \mu$, subepidermal, elliptic, thick-walled; conidiophores, short, simple; conidia ovate to elliptic $8-10 \times 7-8 \mu$. Filiform microconidia ("spermatic") in flaskshaped pycnidia, $0.1-0.2 \times 0.45-0.46 \mu$. The perithecia develop on the old berries, are minute, globose, subepidermal, erumpent and perforate; the asci clavate-cylindrical, obtuse, 60-70 $\times 10-13 \mu$; spores spindle-shaped, $12-17 \times 4.5-5 \mu$.

This very destructive rot disease appears on fruit when the berries are about two-thirds grown as well-defined circular purplish or brown spots which gradually spread. The rotten berries dry and become wrinkled. Appear very much like Melanconium fuliginium (page 110).

187. Infected grapes. 188. Pycnidium, 2/3. 189. Large and small pycnidiospores, 1/12. 190. Ascus, 1/12. 191. Ascospores, 1/12.

Guignardia vaccinil Shear.-On the leaves, flowers and fruits of the cranberry; causing a rotting of the fruits and a spotting of the leaves. The conidia (Phyllosticta stage) formed in pycnidia, 100-120 $\mu$; conidia hyaline, obvoid, $10.5-13.5 \times 5-6 \mu$. The perithecia on the young fruits or flowers are subepidermal globose, and with thick walls; asci clavate, cylindrical, short stipitate, 60-80 $\mu$ and S-spored; ascospores hyaline and spindle-shaped. No paraphyses.

192. Infected berries. 193. Pycnospores, 1/12. 194. Pycnospores with appendages, 1/12. 195. Asci in various stages of development, 1/12. 196. Ascospore, $1 / 12$.

MyCOSPII AREL.LA FRAGARIE (Tul.) Lin. (= Ramularia tulasnei Sacc., page 120).

Mycospit đerella lethalis Stone (= Ascochyta lethalis E. \& E., page 82 ).

Mycospit erella rosigena E. \& E. - On the leaves of the rose. Causes reddish-brown, purple-bordered spots about $3 \mathrm{~mm}$. in diameter; perithecia abundant, minute, 60-75 $\mu$, partly erumpent, black; asci subclavate to oblong, $25-30 \times 8-10 \mu$; spores bi-seriate, clavateoblong, end subacute, hyaline, 1-septate, 10-12 x $2 \mu$.

197. Infected leaf of rose. 198. Peritisecia, 2/3. 199. Ostiolum of perithecium, 1/6. 200. Asci in various stages. 201. Ascospores, 1/12.

Mycospin erella pinoides B. \& B. (= Ascochyta pisi Lib., page 82). 

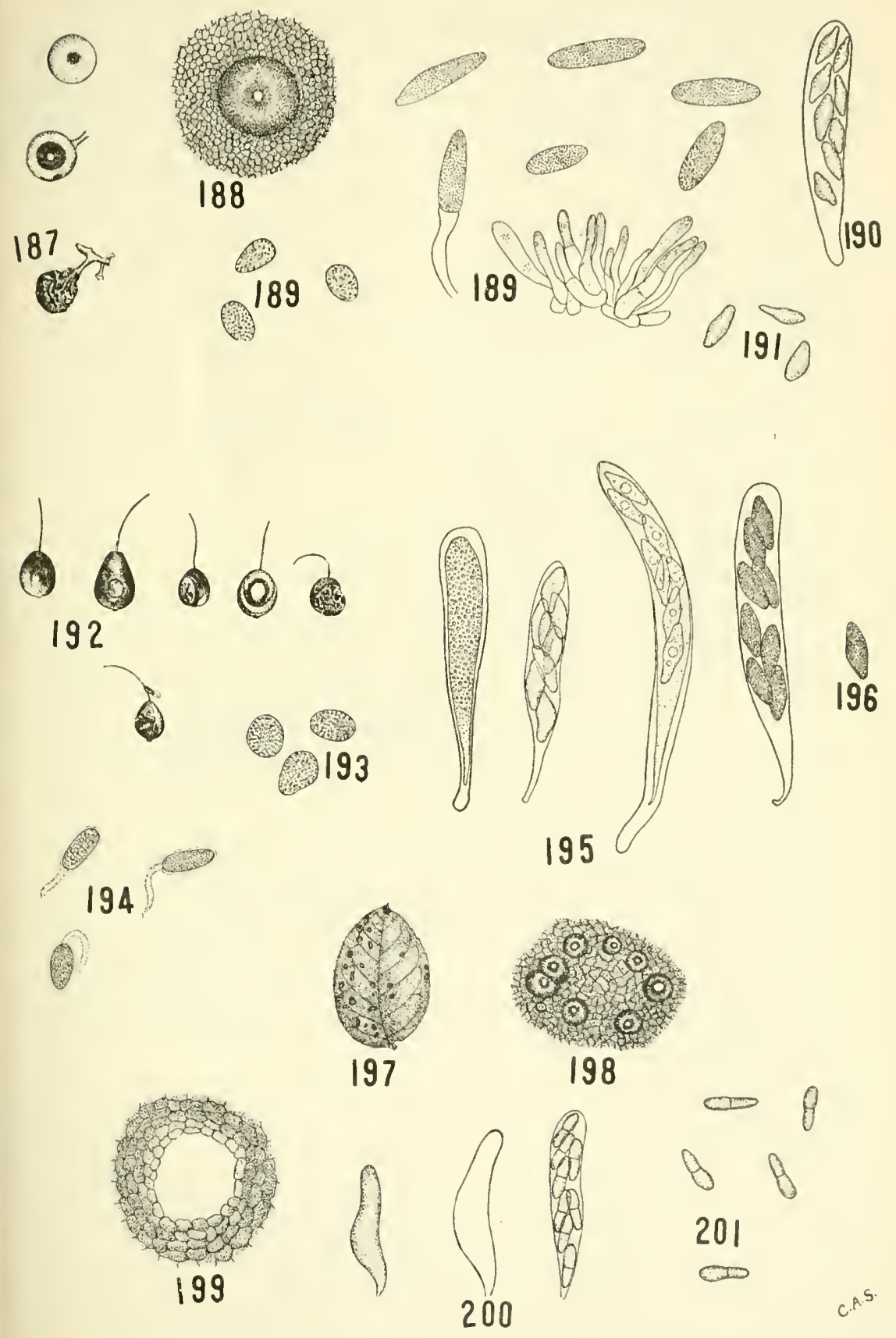
Mrcosphærella SEnTina (Fr.) Schr. (= Septoria piricola Desm., page 92).-On the leaves of pear and apple. In conidial stage causes angular spots of various sizes (depending on host) with ashy-gray centers surrounded by brown or black zone and sometimes an outer purple zone. These color zones are frequently lost in older leaves. Pycnidia ovate, minute, black, on both surfaces of ashy-gray centers; conidiophores hyaline, conidia filiform, usually curved, 2-septate 40-60 × 3-4 $\mu$. Perithecia crowded, black, numerous, on under side of dead spots of over-wintered leaves, long ostiole, erumpent, $80-110 \mu$; asci colorless, clavate, frequently slightly curved, base variable in form, $60-75 \times 11-13 \mu$; ascospores fusiform, straight or very slightly curved, 1-septate, cells equal, $26-33 \times 4 \mu$.

202. Infected leaf of pear. 203. Conidia, 1/12. 201. Perithecia, 1/12. 205. Asci, 1/12. 206. Ascospores, 1/12.

Pleospora hyalospora E. \& E.- On the leaves of alfalfa.* Causes brown to whitish, oblong or marginal leaf spots. Perithecia scattered, depressed, hemispherical, papilliform ostiolum erumpent, $75-90 \mu$. Asci oblong, 75-85 $\times 35-40 \mu$. Ascospores oblong to orate, ends rounded, 3-6 sptate with one or more longitudinal septa, slightly constricted at septa, 25-41 x 12-20 $\mu$.

Note:-It is well known that Alternaria is sometimes the conidial stage of the species of this genus. $1 \mathrm{~T}^{\top} \mathrm{e}$ found an Alternaria constantly associated with this species, but did not prove its connection by culture and inoculation.

207. Infected leaves of alfalfa. 208. Ascus, 1/12. 209. Ascospores, 1/12. 210. Germinating ascospores, 1/12. 211. Perithecium, 1/6. 212. Cross-section of leaflet showing Alternaria associated with Pleospora, 2/3. 213. Conidiophores of same, 1/12. 214. Conidium of same, 1/12. 215. Germinating spore of same, $1 / 12$.

Physalospora cydonie Arnaud.-The perfect stage of Spharopsis malorum, page 78 .

*Apparentiy the same as $P$. hyrlospora reported on Lathyrus satious and Pisum sativum. 
Parasitic Fungi of New Jersey

17
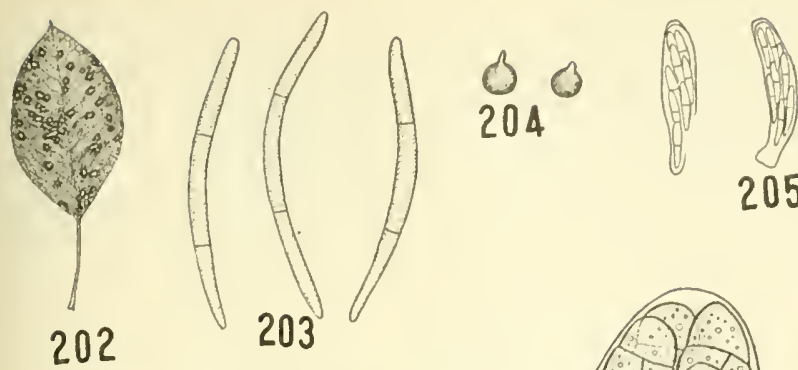

闻

206
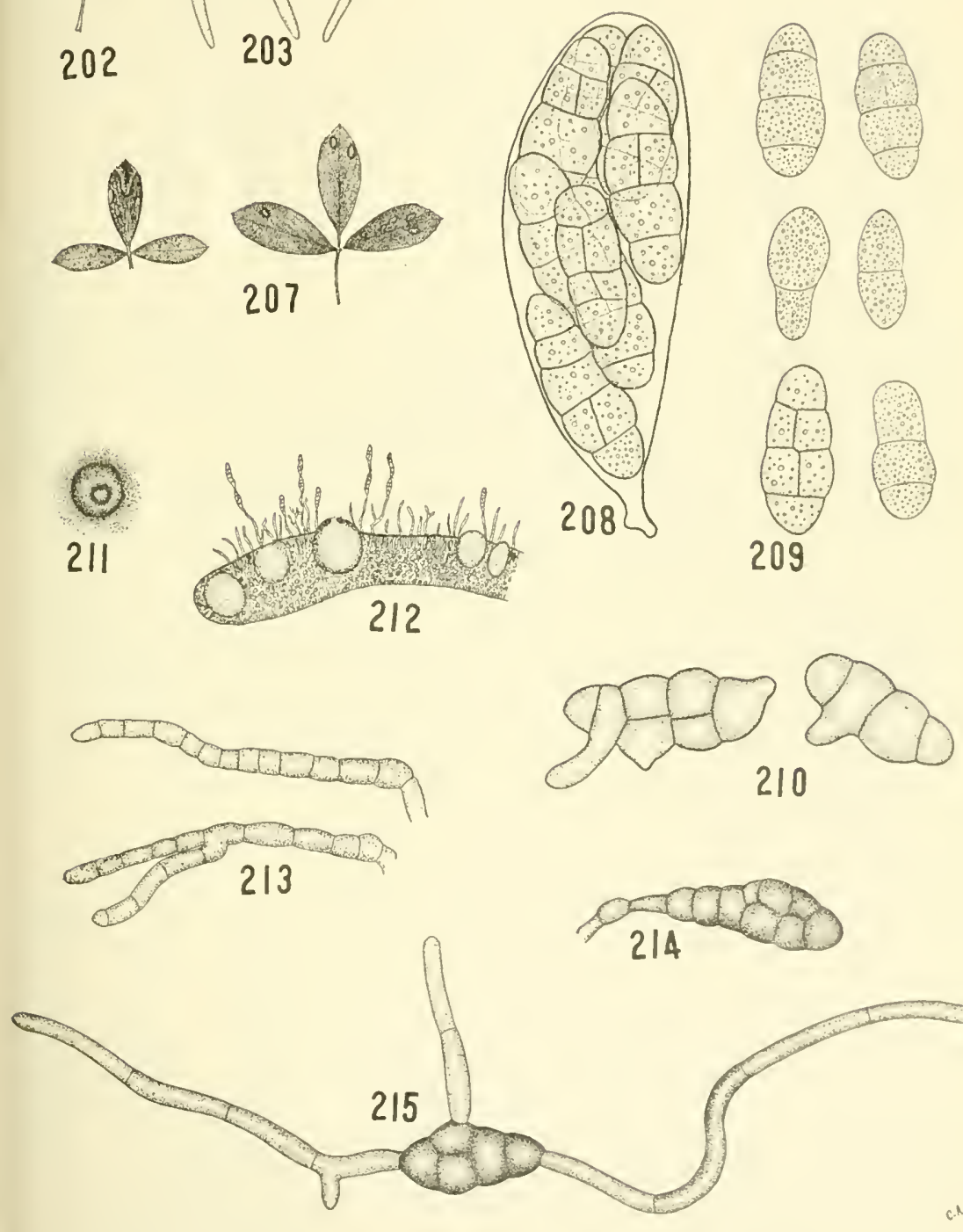
Venturia inequalis (Cke.) Aderh. (= Fusicladium dendrificum (Wal.) Fcl., page 122).-On fruits, twigs and leaves of the apple. Causes spotting and cracking of the fruit and a velvety growth on twigs and under side of leaves. The conidial stage produces blackish-olive velvety patches (sometimes covering the entire lower surface and sometimes on upper surface of leaves and on twigs and fruit), of erect, closely septate brown, mycelium; conidiophores closely non-septate or 1-septate, wary or nodulose brown. $50-60 \times 4-6 \mu$; conidia single, terminal, obclarate, but sometimes irregular in shape, yellowish olive. $30 \times 7-9 \mu$; perithecia maturing in the spring on the old leaves, globose, short-neched, smooth or bristled above, 20-160 $\mu$; asci cylindric, 40-70 $\mu$ long; the ascospores yellowish-green, unequally 2-celled, the upper cell shorter and broader, $11-15 \times 4-8 \mu$.

216. Infected apple leaf. 217. Infected apple. 218. Mycelium from culture, 1/12. 219. Conidiophores and conidia from culture, 1/6, 1/12. 220. Conidia from fruit, 1/12. 221. Infected apple twigs (conidial stage) collected in early spring. 222. Cross-section of same, 2/3. 223. Conidiophores and con:dia from same, 1/12. 224. Asci, 1/12. 225. Ascospores, 1/12.

Venturia gaultheriæe E. \& E. - On the leaves of Gaultheria procumbens. Causes orbicular or irregular dark brown spots with grayish centers, $1 / 3 \mathrm{~mm}$. in diameter. Perithecia scattered, orbicular, membranous, $75 \mu$ in diameter, with few black spreading bristles; asci ovate to oblong, slightly curved, 30-35 x $8-11 \mu$; conidia ovate to oblong, septate, slightly constricted, 3-4 guttulate, slightly curved, hyaline, $11-14 \times 3 \mu$.

226. Infected leaf of Gaultheria procumbens. 227. Perithecia, 2/3. 225 Asci and ascospores, 1/12.

Ventura pirina Adler (= Fusicladium pirimum (Lib.) Fel.. page 122).

LEPTOSPH ÆRIA CONIOTHYRIUM (Fcl.) Sacc. (= Coniothyrium fuckelii Sacc., page 80). 

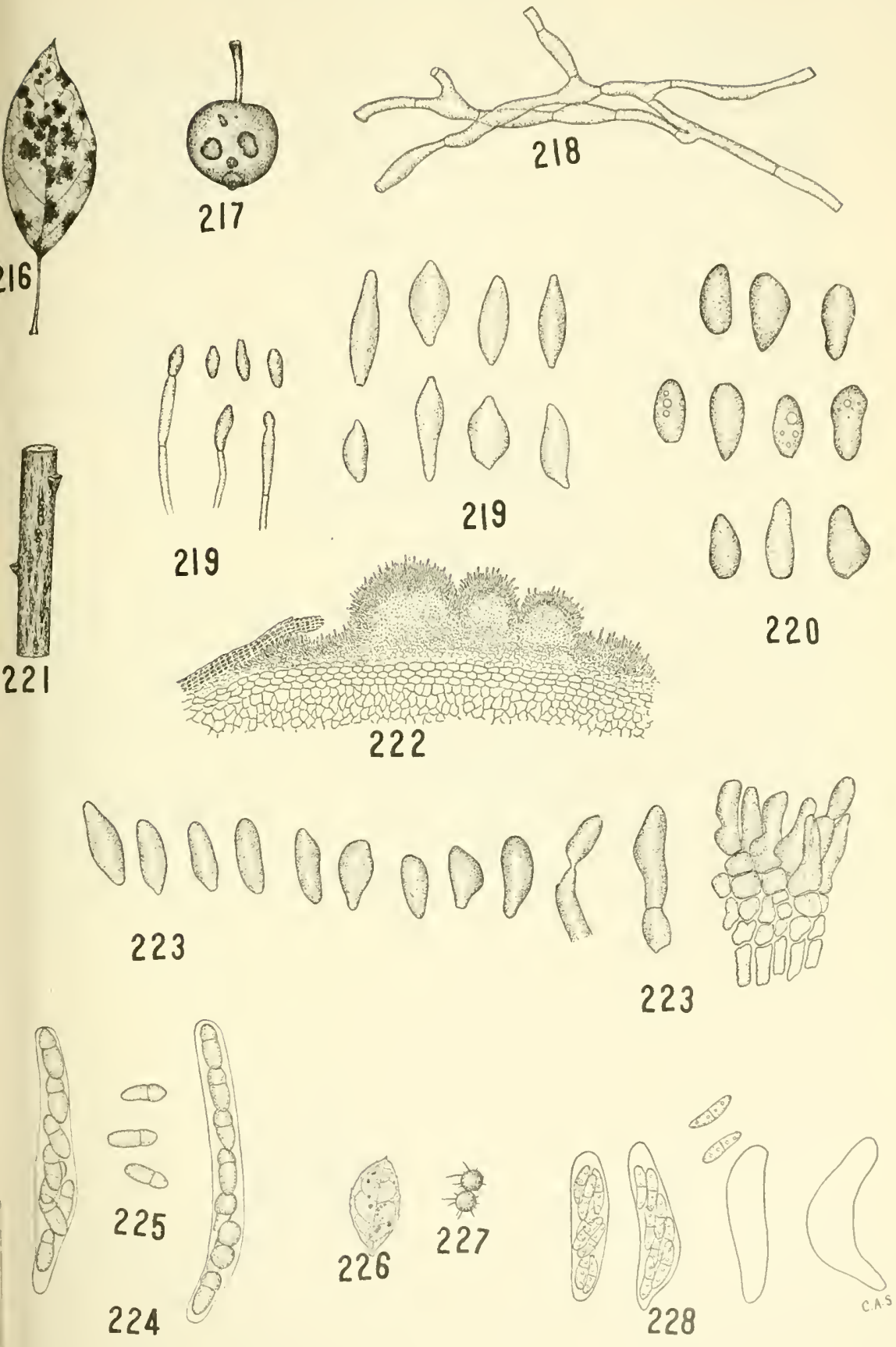
Glojierella rufomaculans (Berk.) S. \& S. (= Gloeosporium rufomaculans (Berk.) Thüm., page 102. - On the fruits and twigs of the apple. Causes a rotting of the former and cankers on the latter. The fruit rot originates as small, yellowish-brown spots usually with a purplish-red border; the spots enlarge, becoming dark brown in center with light brown margins and gradually become more or less sunken; the twig or branch cankers are circular or oblong, somewhat sunken, dry and more or less cracked.

The acervuli (Gloosporim fructigenum, G. rufomaculans) arranged in circles and discharge an abundance of sticky, pink spores, spores are variable in size and shape, $28 \times 3.5-7 \mu$.

The perithecia are subspherical, more or less grouped, asci subclavate, 55-70 $\mu$; ascospores 12-22 $\times 3-5 \mu$.

229. Infected apple. 230. Conidia from fruit, $1 / 12$. 231. Conidia from. culture, 1/12. 232. Perithecium, 2/3, 1/6. 233. Ascus, 1/11. 234. Ascospores from same, $1 / 12$.

GLOMERELla RUFOMACUlaNs raccinit Shear. - On the upper surface of leaf and on fruit of the cranberry, causing the anthracnose disease. Acervuli small, scattered over both leaves and old berries; conidiophores non-septate, tapering, 15 to $20 \mu$ long; conidia light flesh-colored in mass, oblong to elliptical, sometimes slightly smaller at one end, hyaline, $12-18 \times 4.5-6 \mu$; perithecia membranous, subglobose or slightly pear-shaped; asci clavate, sessile or short stipitate, $60-72 \times 10-12 \mu$; sometimes accompanied by apparently evanescent paraphyses; sometimes slightly unequilateral or curved hyaline becoming pale green-yellow, 9-1S x 5-7.5 $\mu$.

235. Mrycelium, 1/6. 236. Bristle, conidiophores and conidia, 2/3. 237. Conidia, 1/12. 238. Ascus and ascospores, 1/12. 

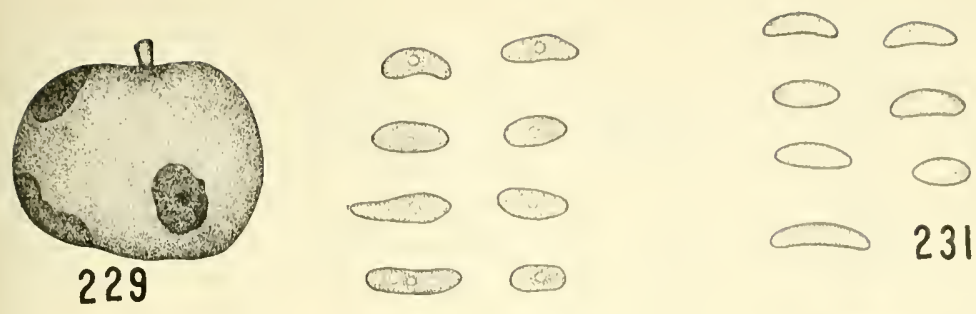

230
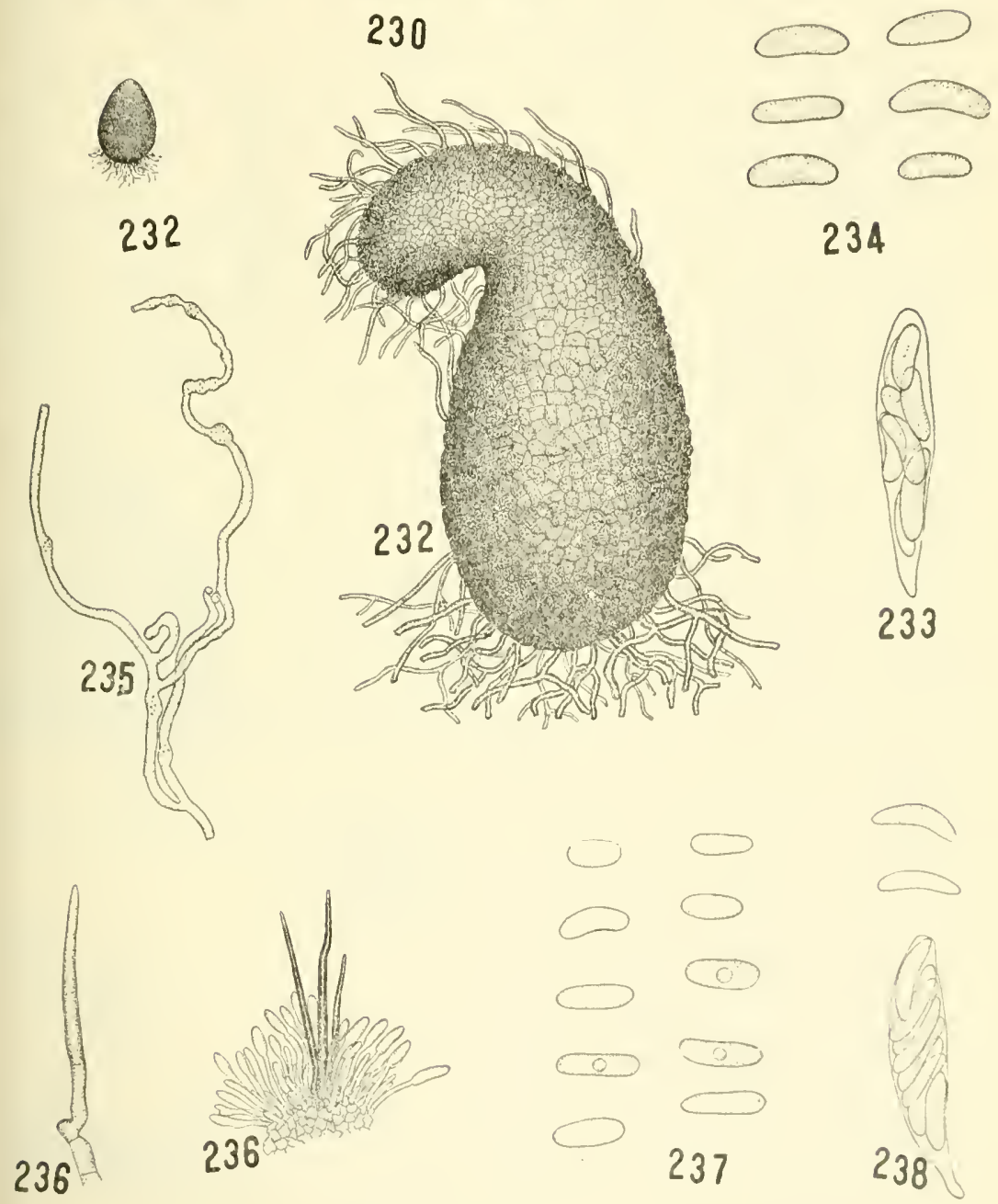

234
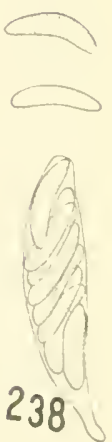
Glomerella rubicola (Ston.) S. \& S.-On the petioles and on canes of raspberry at point of union of petiole and cane. Causes a spur blight and falling of the leaves. Acervuli most abundant at point of union of petiole and cane; conidiospores (= Colletotrichum rubicolum E. \& E., page 108)) oblong or elliptical, salmon-colored to dark brown, 11-12 $\times 3-4 \mu$; perithecia in same location as acervuli; with prominent neck, ascus long with short base, and slightly pointed at tip; ascospores long, rounded at the ends, and slightly curved.

239. Infected raspberry cane. 240. Bristles, 1/12. 241. Conidia, 1/12. 242. Perithecia, 2/3, mostly from petioles. 243. Asci and ascospores, 1/12, from two sources.

Glomerella cingulata (Atk.) S. \& S.-On Ficus elastica. Causes a dying of the leaves (Glocosporium cingulatum, page 98), acervuli black, 100-150 $\mu$; conidiophores numerous, crowded, nonseptate, hyaline; conidia, oblong to elliptical, straight or curved, pointed at one end, $10-20 \times 5-7 \mu$; perithecia in groups, dark brown, flask-shaped, membranous, more or less hairy, 250-320 x $150 \mu$; asci clavate, $64 \times 16 \mu$; ascospores elliptical, slightly curved. $20-28 \times 5-7 \mu$.

244. Perithecia, 2/3. 245. Cross-section of acervulus, $2 / 3$. 246. Conidiophores and conidia, 1/12. 247. Asci, 1/12. 248. Ascospores, 1/12.

Glomerelia cincta (B. \& C.) S. \& S. - On Calathea vitata. Causes large, irregular yellow to brown spots on the leaves (Colletotrichum cinctum, page 104). Acervuli erumpent; conidia elliptical ; 12-18 x 3-5 $\mu$; perithecia flask-shaped, membranous, in groups, 180$280 \mu$; asci clavate, truncate or obtuse, $65-70 \mu$; ascospores elliptical ; is sually curved, $16.5-24 \times 3.3-6.6 \mu$.

249. On infected leaf of Culathea zitata. 250. Conidia, 1/12. 251. Peri thecia, 2/3, 1/6. 252. Asci, 1/12. 253. Ascospores, 1/12. 
Parasitic fungt of New Jersey

$\prod_{239} \int_{240}$

0 : 0

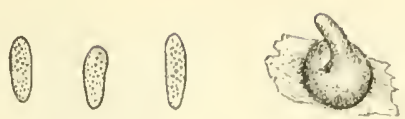

10

241

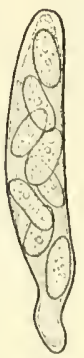

(2)

243
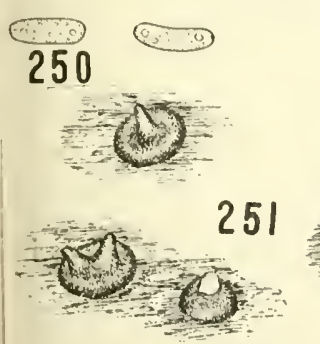
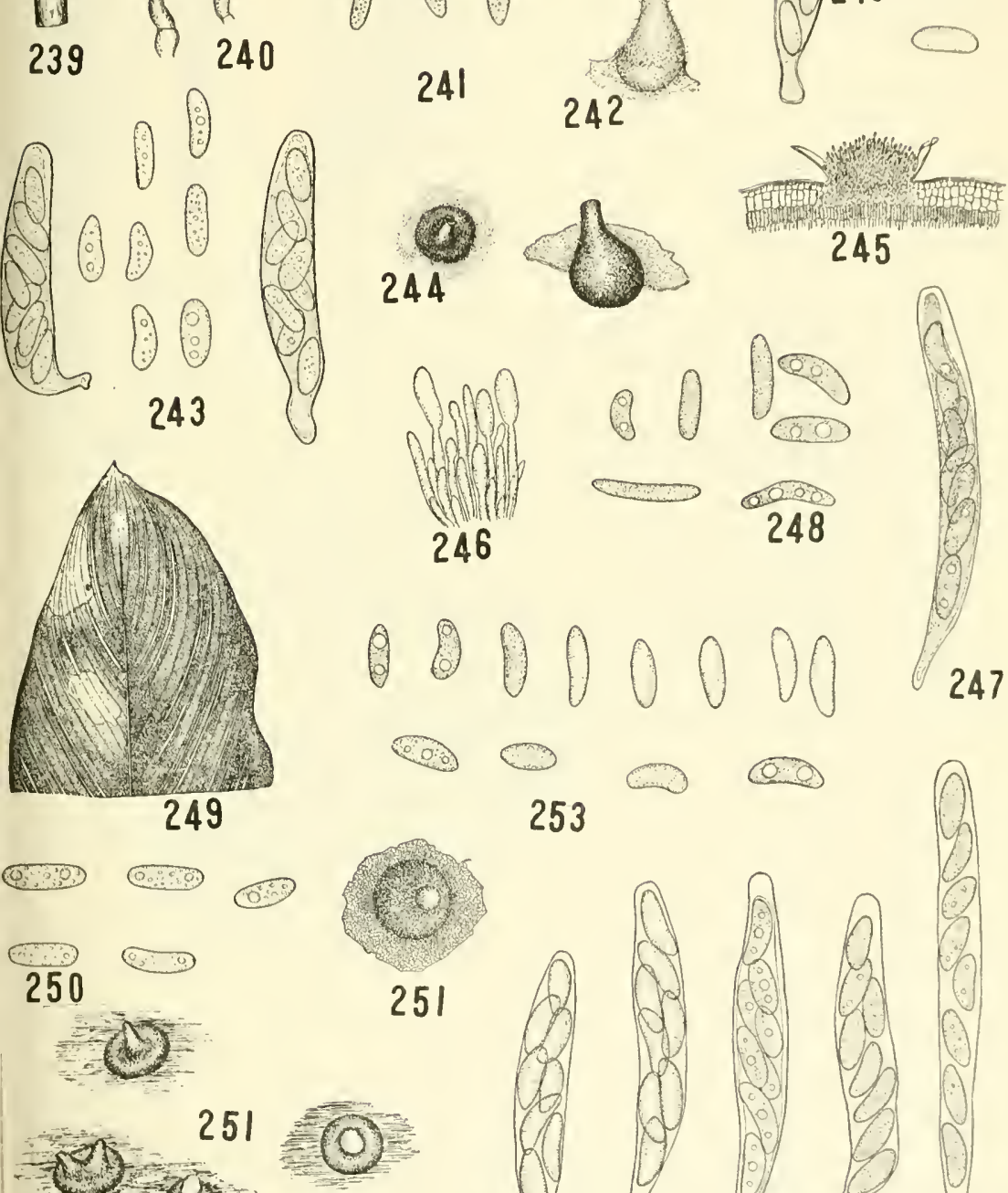
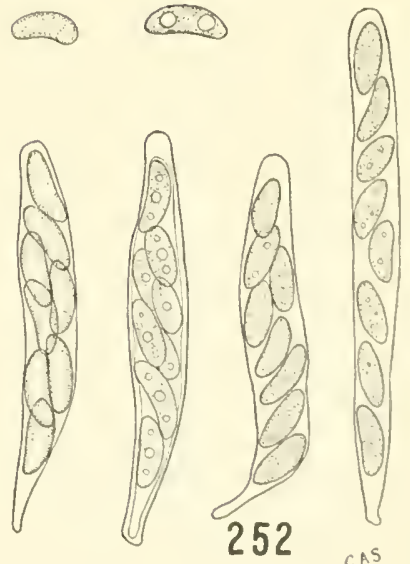
-On leaves of Dracaena sanderiain. and $D$. temininalis. Causes a spotting and dying of the leaves (probably $=$ Colletotrichum dracaenae Allesch). Acervuli on both sides of the leares and also on canes, scattered or grouped, flesh-colored becoming black; bristles dark brown, 40-100 $\times 2.5-5 \mu$; conidiospores crowded, short hyaline; usually straight; ends usually rounded, hyaline, $13-30 \times 3.5 \mu$; ascospores $13.3-20 \times 3.3-6.6 \mu$.

257. Infected leaf of Dracaena sanderiana. 255. Infected cane showing acervuli. 256. Acervuli on leaf, 2/3. 257. Bristle from cane, 1/12. 258. Conidia, 1/12. 259. Perithecium, 2/3. 260. Tip of perithecium, 2/3. 261. Rupturing of perithecium, 1/12. 262. Ascus, 1/12. 263. Ascospores, 1/12. 264. Germinating spores, 1/12. 265. Bristle from D. terminalis, 1/12. 266. Conidia from same, 1/12. 


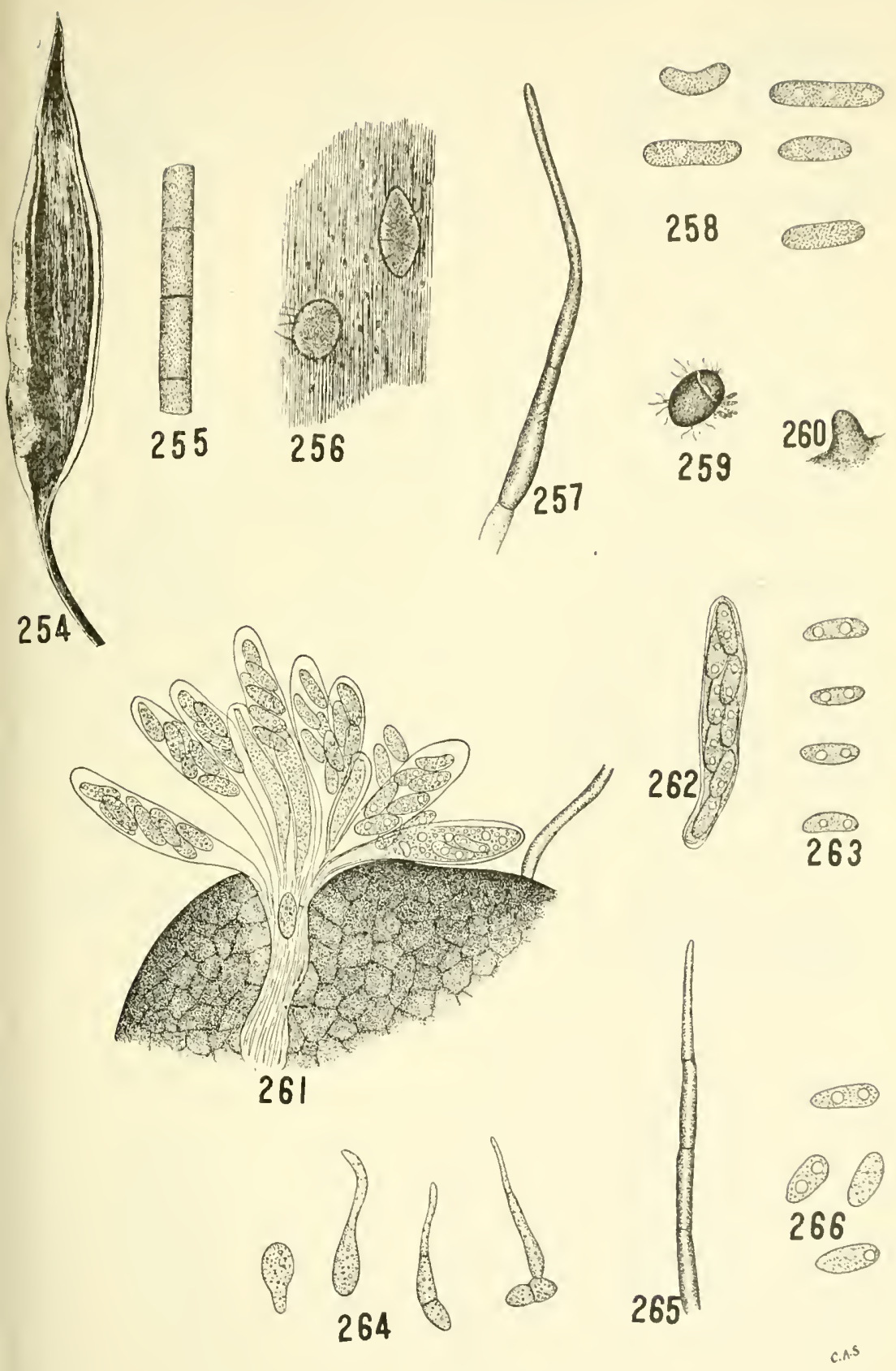


On Curmeria wallisi. Causes a spotting and a dying of the leaves; conidiospores $13.3-20 \times 3.3-6.6 \mu$; ascospores $13-20 \times 6.6 \mu$.

267. Acervuli, 2/3. 268. Bristle and conidiophores, 1/6. 269. Conidia, 1/12. 270. Perithecia, 2/3. 271. Ascus, 1/12. 272. Ascospores, 1/12. 273. Germinating ascospores, $1 / 12$.

On the living leaves of Begonia. Causes reddish-brown spots; acervuli on upper surface of leaf, somewhat rounded, scattered; conidiospores cylindrical, non-septate, hyaline or base slightly smoky-colored, 12-14 $\mu$; conidiospores oblong to elliptical, ends ustally rounded, hyaline, 16-17 x 4-5 $\mu$; (given in Saccardo as Glaosporium begonice Mag., but we found bristles); perithecia conical; ascospores $10-16.6 \times 3.3-6.6 \mu$.

274. Bristle, 1/12. 275. Conidiophores and conidia, 1/12. 276. Perithecia, 2/3. 277. Asci, 1/12. 278. Ascospores, 1/12.

On the leaves of Cocos plumosa. Causes a spotting; perithecia flask-shaped ; ascospores 15-61.6 × 5-6.6 $\mu$.

279. Perithecia, 2/3. 280. Asci, 1/12. 281. Ascospores, 1/12. 

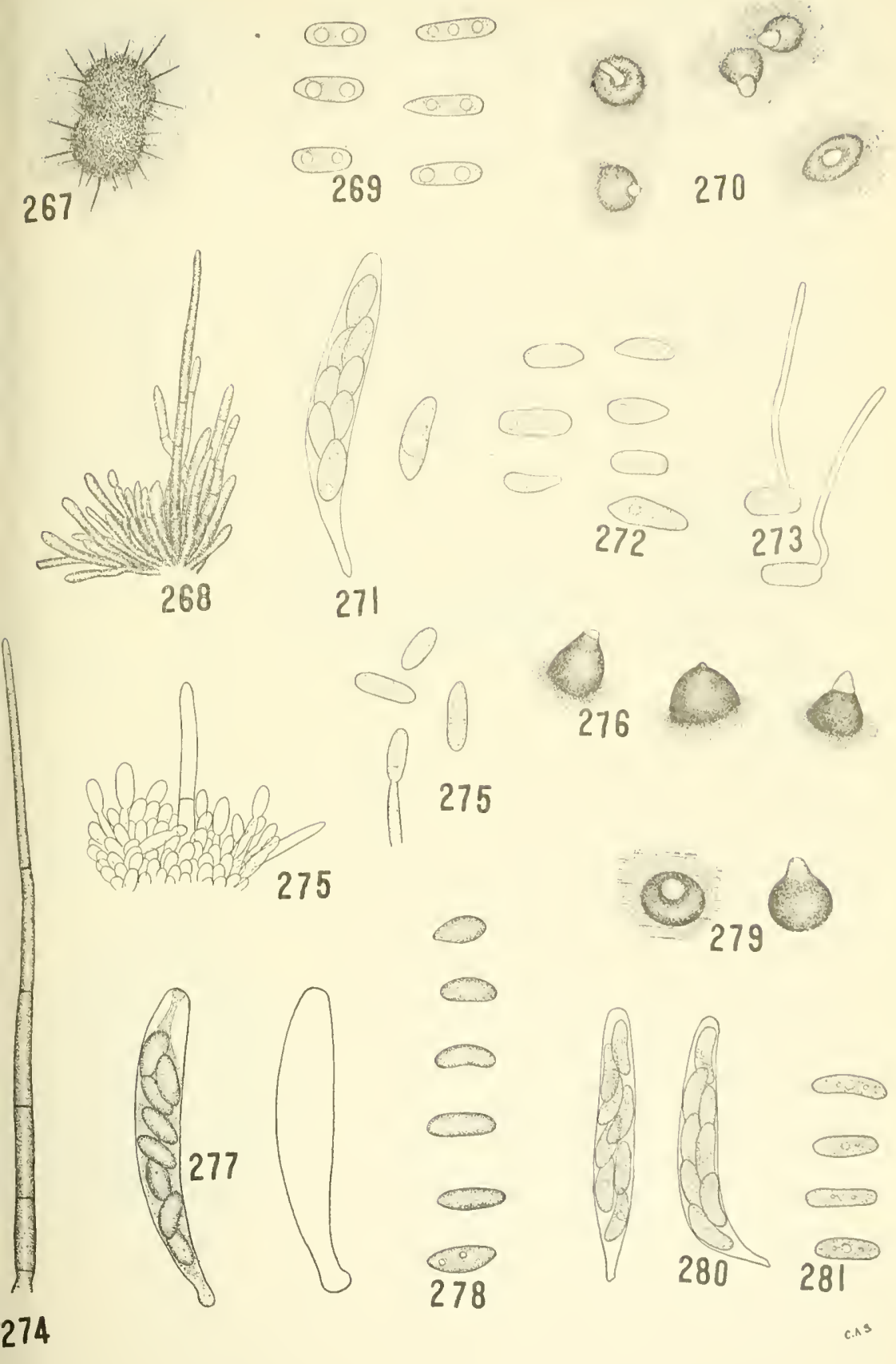
On the stems of roses. A weak parasite attacking weak plants and causing a dying of the infected parts. Acervuli scattered; conidiophores $3.3 \mu$ wide; spores hyaline but salmon-colored or pinkish in mass, guttulate, $18-21.6 \times 6-7.3 \mu$ (= Gloosporium rosea Hals.). Ascogenous stage corresponding to the preceding.

282. Perithecia, 2/3. 283. Conidiophores and conidia, 1/12, from two sources. 284. Asci, 1/12.

Glomerella cincta (B. \& C.) S. \& S. (= Gloosporimm polymorphum Tunchili, page 100).

Glomerella fusarioides Edgerton (= Gloosporium fusarioides E. \& E., page 100).

Glomerella piperata (E. \& E.) S. \& S. (= Gloosporium pipe ratum E. \& E., page 100).

Gromonia andropogonis E. \& E.-On the leaves of Andropogon. Perithecia buried in the tissue of the leaf, subglobose, collapsing from below, membranaceous, black, $5 \mathrm{~mm}$. in diameter, beak sublateral and erumpent, cylindrical, oblong-lanceolate, $40 \times 10 \mu$; no paraphyses; spores crowded, cylindrical to fusoid, septate, each cell 1-2 guttulate, slightly curved, hyaline, $20-25 \times 4 \mu$.

285. Perithecia, $2 / 3$.

Gnomonia Carye Wolf. (= Gloosporium caryce E. \& D., page 98).

Gnomonia clavulata Ell. - On the fallen leaves of Quercus nigra and Carya sp. Perithecia membranaceous, globose, rough, 100-165 $\mu$ in diameter, buried in tissues of the leaf, the base projecting on lower surface and cylindrical, obtuse beak above; asci narrow-elliptical, sub-acute, 4-guttulate becoming unequally 1-Septate and obtuse, hyaline to yellowish, 7.5-9 $\times 2-2.5 \mu$.

286. Perithecium, $2 / 3$.

Gromonia leptostyla (C. \& D.) Bot. (= Marssonia juglandis (Lib.) Sacc., page 110).

Gromonia veneta (Sacc. \& Speg.) Kleb. (= Gloosporium nevvisequm (Fcl.) Sacc., page 100). 
Diaporthe batatatis Harter \& Field ( = Phoma batatce E. \& H., page 70).-On the roots, stems and leaves of the sweet potato. Causes a dry rot. Pycnidia loosely grouped, emersed, erumpent, ostiolate $60-13 \times 60-110 \mu$. Conidia oblong to fusoid, non-septate, usually 2 -guttuate, hyaline, $6-8 \times 3.5 \mu$. Perithecia subglobose, $120-$ $350 \mu$; asci clavate to cylindrical, 23-38 $\times 7-12 \mu$; ascospores oblong to fusoid, 1-septate, slightly constricted, 2-4 guttulate, hyaline, S-12 $\mathrm{x} 4-6 \mu$.

287. Cross-section of infected sweet potato showing rot following inoculation. 288. Small root showing pycnidia, 289. Pycnidia, 2/3. 290. Spores from same, 1/12. 291. Pycnidium from culture, 1/12. 292. Spores from same, 1/12. 293. Perithecia from culture, 2/3. 294. Asci, 1/12. 295. Ascospores, 1/12. 296. Scolecospores, 1/12.

Endothia parasitica (Murrill) And.-- On the branches and trunk and sometimes on the fruits of the chestnut. Causes very pronounced cankers and finally kills the tree. Pycnidia large, densely grouped, smooth or nearly so, loculated; pycnospores emerging in tendrils, pale yellow, $1-3.5 \mu$; perithecia grouped, flaskshaped with long necks, ostiolate; asci oblong-clavate, 45-50 × $9 \mu$; ascospores oblong, uniseptate, slightly constricted, hyaline, 9-10 x 4-5 $\mu$.

297. Cross-section of stroma showing pycnidia, 2/3. 298. Pycnospores, 1/12. 299. Cross-section of stroma showing perithecia, 2/3. 300. Asci, $1 / 6$ and 1/12. 301. Ascospores, 1/12. 

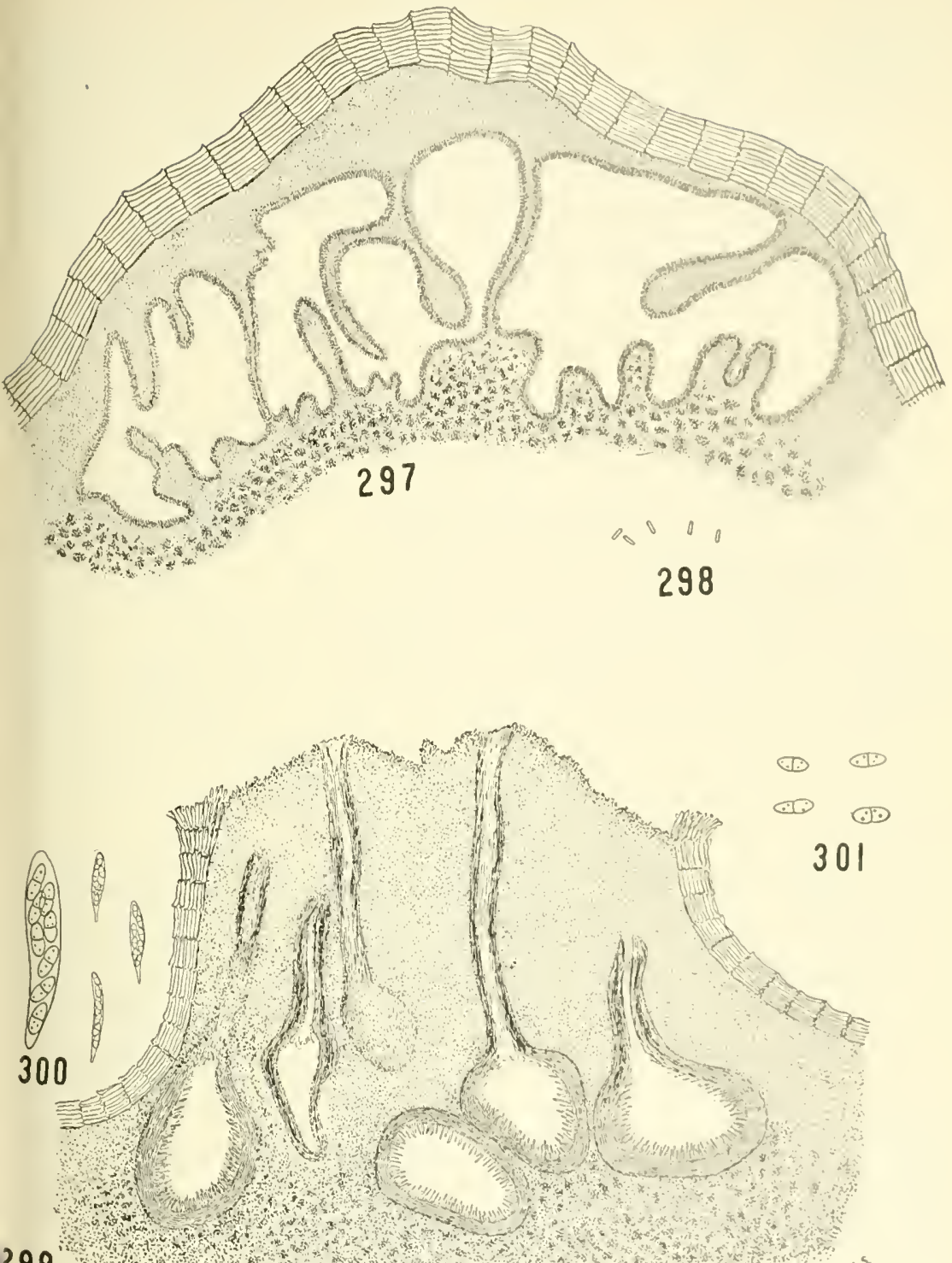
Botryospheria RIBIS G. \& D. (= Dothiorella sp., page 76).On the canes of the currants. Causes a dying back or blight. Pycnidia compound, pycnospores fusoid, non-septate, hyaline, 18-31 $\mathrm{x} 4.3-8 \mu$. Perithecia somewhat cone-shaped, papillate, ostiolate, interspersed among the pycnidia, $175-250 \mu$; asci clavate, $80-120 \mathrm{x}$ 17-20 $\mu$; numerous filiform paraphyses; ascospores fusoid, nonseptate, hyaline, $16-23 \times 5-7 \mu$.

302. Twig of currant showing pycnidia. 303. Same enlarged. 304. Crosssection of stroma showing pycnidia, 2/3. 305. Pycnospores, 1/12. 306. Crosssection of stroma showing perithecia, 2/3. 307. Ascus, 1/12. 308. Ascospores, $1 / 12$.

Phyllosticta AcERicola C. \& E.-On the leaves of the maples. Causes irregular, brown-margined spots which frequently unite to form blotches. Pycnidia rather abundant in the central part of the spot: subepidermal, flask-shaped, dark brown, measuring $120 \mu$; conidia orate, $8-0 \times 5-6 \mu$.

309. Infected maple leaf. 310. Pycnidia, 2/3. 311. Spores, 1/12.

Phyllosticta Alliariafoliz. Allesch. - On the leaves of cultivated Campanula. Causes more or less circular, angular, ashycolored spots with obscure margins, $+12 \mathrm{~mm}$. in diameter. Pycnidia lenticular, erumpent, dark: spores oroid or oblong, small non-septate, hyaline, $4-6 \times 2-3 \mu$.

\section{Spores, $1 / 12$.}

Phyllosticta ampelopsidis E. \& M. - On Virginia creeper (Ampelopsis quinquefolia), causing leaf spots. It is probably identical with $P$. labruscae Thüm. of the grape, which is an imperfect stage of Guignardia hidwellii (page 44).

313. Infected leaflet of Ampelopsis quinquefolia. 314. Infected leaf of Ampelopsis tricuspidata. 315. Spore, 1/12.

Phyllosticta aristolochi玉 F. Tassi.-On the leaves of Aristolochia. Causes more or less circular, or irregular dirty white leaf spots surrounded by a thin brown border. Pycnidia small lenticular, densely scattered, 50-60 $\mu$ in diameter; spores orate or elliptical, hyaline, non-septate, 3-6 × 2-2.8 $\mu$.

316. Infected leaf of Aristolochia macrophylla. 317. Spores, 1/12.

Phyllosticta Alerswatdi Allesch.-On the leaves of Buxus semperirens. Causes white leaf spots with indistinct margins. Pycnidia on both surfaces, few, sometimes many, ostiolate light brown; spores oroid or oblong, non-septate, hyaline, 5-7 x 3-4 $\mu$.

318. Pycnidia, 2/3. 319. Spores, 1/12. 
Phyllosticta bataticola E. \& M.-On the leaves of the sweet potato. Causes small, roundish, whitish spots with purplish margins. Pycnidia scattered, minute, and black; conidia ellipsoid, $5 \times 2 \mu$.

320. Infected leaf of Convolvulus sp. 321. Spores, 1/12.

Phyllosticta castanez: E. \& E.-On the leaves of the chestnut. Causes brown or ochre-colored spots with obscure margins, $100 \mu$ in diameter, collapsing, spores hyaline or smoky-colored, oval, sometimes obtusely pointed at one end, 5-7 $\times 2-2.5 \mu$.

322. Portion of infected leaf of Castanea dentata. 323. Spores, 1/12.

Phyllosticta catalpe E. \& M.-On the leaves of the Catalpa. Causes more or less circular, scattered, of ten confluent, brown spots 3-6 mm. in diameter. Pycnidia scattered sub-cuticular, small black, erumpent, $112 \times 84 \mu$; conidia 5-7 x 2.5-4.5 $\mu$.

324. Portion of infected leaf of Catalpa sp. 325. Pycnidia, 2/3. 326. Cross-section of pycnidium, 2/3. 327. Spores, 1/12.

Phyllosticta circumscissa Cke. - On the leaves of peach, cherry and other drupaceous hosts. Causes orbicular, reddishbrown spots with reddish margins, center falling out and producing shot-hole effect. Pycnidia dark, minute, scattered, spores elliptical, ovoid, $8 \times 2 \mu$ (in culture ovoid, elliptical or irregular, $2.6 \times 2.6$ $4.4 \mu$ ). Usually associated with Cercospora.

328. Pycnidia, 2/3 from cherry leaf. 329. Spores from same, 1/12. 330. Spores, 1/12, from peach leaf. 331. Pycnidia, 2/3 from culture. 332. Spores from same, $1 / 12$.

Phyllosticta clethricola C. \& M.-On the leaves of Clethra alnifolia. Causes circular, frequently confluent, reddish-brown spots, 2-10 $\mathrm{mm}$. in diameter, with dark borders. Pycnidia on both surfaces of leaf, small, erumpent, ostiole small; conidia hyaline, ovate, guttuate surrounded by gelatinous envelope which frequently forms hair-like appendage, $9 \times 6 \mu$.

333. Infected leaf of Clethra alnifolia. 334. Spores, 1/12.

Phyllosticta concentrica Sacc. - On the leaves of Hedera helix. Causes large, more or less circular, pale, dry spots. Pycnidia arranged concentrically, lenticular, dark, ostiole broad, 90-100 $\mu$; spores globose to ovoid, hyaline, minutely pluriguttulate, 7.7-10 x 6.6-6.8 $\mu$.

\section{Pycnidium, 2/3. 336. Spores, 1/12.}

Phyllosticta cruenta (Fr.) Kick.-On the leaves of Smilacina racemosa. Causes circular or oblong, sometimes confluent, reddish 

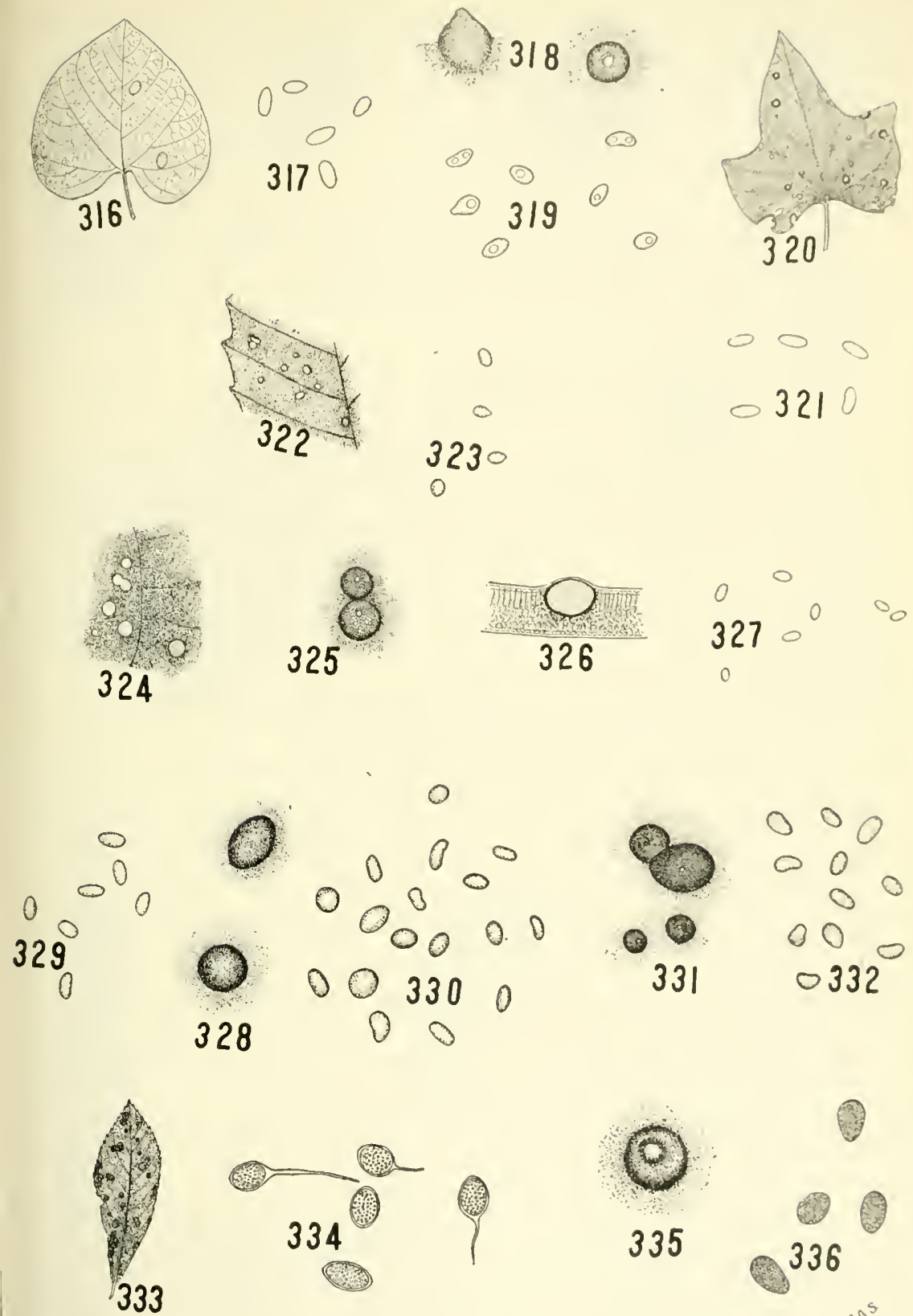
spots, which become grayish with reddish borders at maturity, about 3-10 mm. in diameter. Pycnidia grouped or scattered, globcselenticular, olive-black, erumpent; conidia hyaline, oval or ovate to oblong, granular, 14-16 x 5.5-6.5 $\mu$.

337. Infected leaf of Smilacina racemosa. 338. Pycnidium, 2/3. 339. Spores, $1 / 12$.

Phyllosticta Grossulari玉 Sacc.-On the leaves of the gooseberry. Causes more or less circular, dry, grayish-white spots with darker margins. Pycnidia scattered; conidia ovoid or ellipsoid, hyaline, $5-6 \times 3 \mu$.

340. Infected leaf of Grossularic sp. 341. Pycnidium, 2/3. 342. Spores, $1 / 12$.

Piryloosticta halstedi E. \& E.-On living leaves of Syringa rulgaris. Causes reddish spots between larger veins, becoming brown and wrinkled. Spots on both surfaces of the leaves $1 / 4$ to $11 / 4 \mathrm{~cm}$. in diameter and with definite narrow dark border. Pycnidia on both sides of leaf, few, lenticular, $100-150 \mu$ in diameter, spores broad, fusoid-oblong, straight, granular, rounded at the ends, $15-20 \times 5-7 \mu$.

343. Part of infected leaf of Syringz vulgaris. 341. Pycnidium, 2/3. 345. Spores, 1/12 from two sources. 346. Germinating spores, 1/12.

Phillosticta Hibisci Peck.-On leaves of Hibiscus moschatus var. crimsoni. Causes oval, circular or irregular, ashy-gray spots with narrow inner black and broad outer reddish burders, about 4- $8 \mathrm{~mm}$. in diameter. Pycnidia on the upper surface of the leaf, erumpent, ostiolate, brown to black, conidiophcres single or branched, 10-20 $\mu$ long; spores oblong, oval, irregular, sometimes slightly curved, 1-2 guttulate, 7.5-10 × 3-4 $\mu$.

347. Portion of infected leaf of Hibiscus moschatus. 348. Spores, 1/12.

Phyllosticta hortortin Speg.-On the eggplant. (See Phomopsis vexans (Sacc. \& Syd.) Harter, page 74.)

Pirylosticta Labrusce. Thüm.-(See Guignardia bidruelli, page 41.)

Phyllosticta macllicola. Hals. - On the leaves of Dracana terminalis and other species of Dracana. Causes small, brown, ovate, somewhat angular spots with yellowish borders. Pycnidia borne on both surfaces, ostiolate, black and about $32.5 \mu$ in diameter; spores ovate-oblong, frequently curved, hyaline.

349. Infected leaf of Dracaena terminalis. 350. Pycnidium. 351. Spores, $1 / 12$. 
Parasitic Fungr of New Jersey

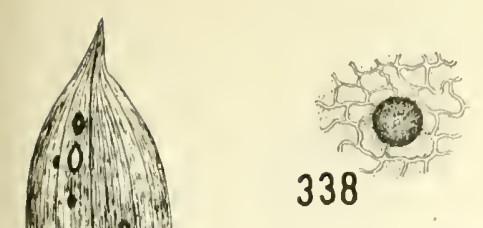

337
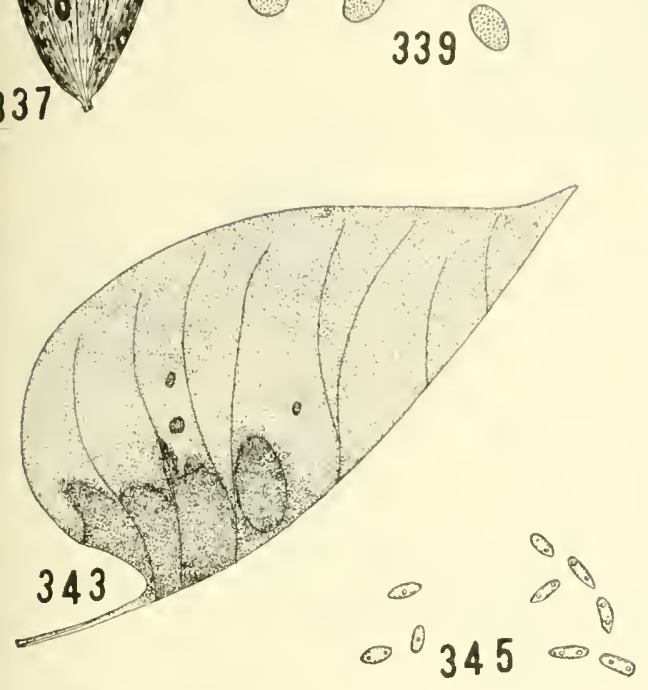

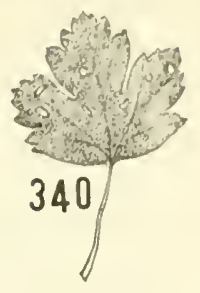

341

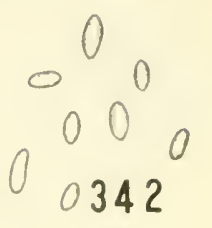

344

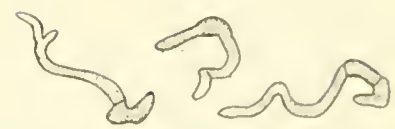

346

A

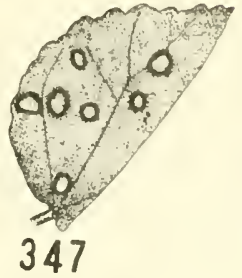

000
00

$\theta \theta \theta$

348

(2)

349

350

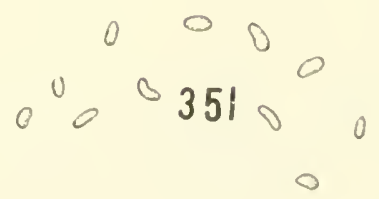


Phyllosticta orontil E. \& M. var. advena.-On the leaves of Nympha advena. Causes pale yellow to brawn more or less concentrically-ridged spots, surrounded by narrow, definite, sub-elevated margin, center definitely margined and pale and bearing the pycnidia; pycnidia on both sides of the spot, erumperat; spores ovate and oblong, somewhat irregular, $5-8 \times 2.5-3 \mu$. Also reported on Orontium aquaticum.

352. Spots on leaf of Nymphaa advena. 353. Pycnidia, 2/3. 354. Spores, $1 / 12$.

Phyllosticta Pavi玉 Desm. (= Guignardia asculi (Peck.) Stewart, page 42).

Phyllosticta phaseolina Sacc. - On the leaves of beans. Causes scattered, irregular, more or less circular spots about 2-1Q

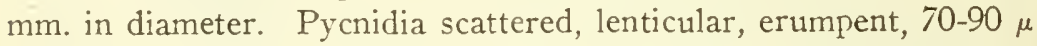
in diameter; conidia oroid to oblong, occasionally slightly curved, 4-6 $\mathrm{x} 2-2.5 \mu$.

355. Infected leaflet of bean. 356. Leaf spots. 357. Pycnidia, 2/3. 358. Spores, 1/12.

Phyllosticta Rosicola Mass. - On the leaves of the rose. Causes irregular reddish spots, becoming dry with age, and often limited to the upper surface. Pycnidia prominent on the under side, black punctiform, $50-70 \mu$ in diameter; spores small oblong, $2.5 \times 1 \mu$.

359. Infected leaf of rose. 360. Pycnidium, 2/3. 361. Ostiolium, 1/12. 362. Spores, $1 / 12$.

Phyllosticta solitaria E. \& E. - On the leaves, twigs and fruits of the apple. Causes spots on leaves, cankers on twigs, and blisters on fruits. The leaf spots are small, irregular in shape, light brown, yellowish or whitish. The cankers on the twigs and fruit branches are usually small, with definite outline, reddish or purplish, becoming gray with a purplish margin which usually disappears; bark cankers along the line of demarcation between diseased and healthy tissue. On water sprouts the cankers are much larger and resemble those on the fruit. The fruit blotches start as small, light brown blotches which enlarge, become darker in color and irregular and jagged in outline. Pycnidia small and immersed in the tissue of the host. Conidia broadly elliptical, 8-10 $\times 5-6 \mu$.

363. Infected apple. 364. Pycnidium, 2/3. 365. Cross-section of pycnidium, 2/3. 366. Spores, 1/12. 367. Infected apple twig. 368. Pycnidium from same, 2/3. 369. Spores from the same, 1/12. 370. Germinating spores, 1/12. 371. Infected fruit of English hawthorne. 372. Pycnidium, 2/3. 373. Spores, $1 / 12$. 


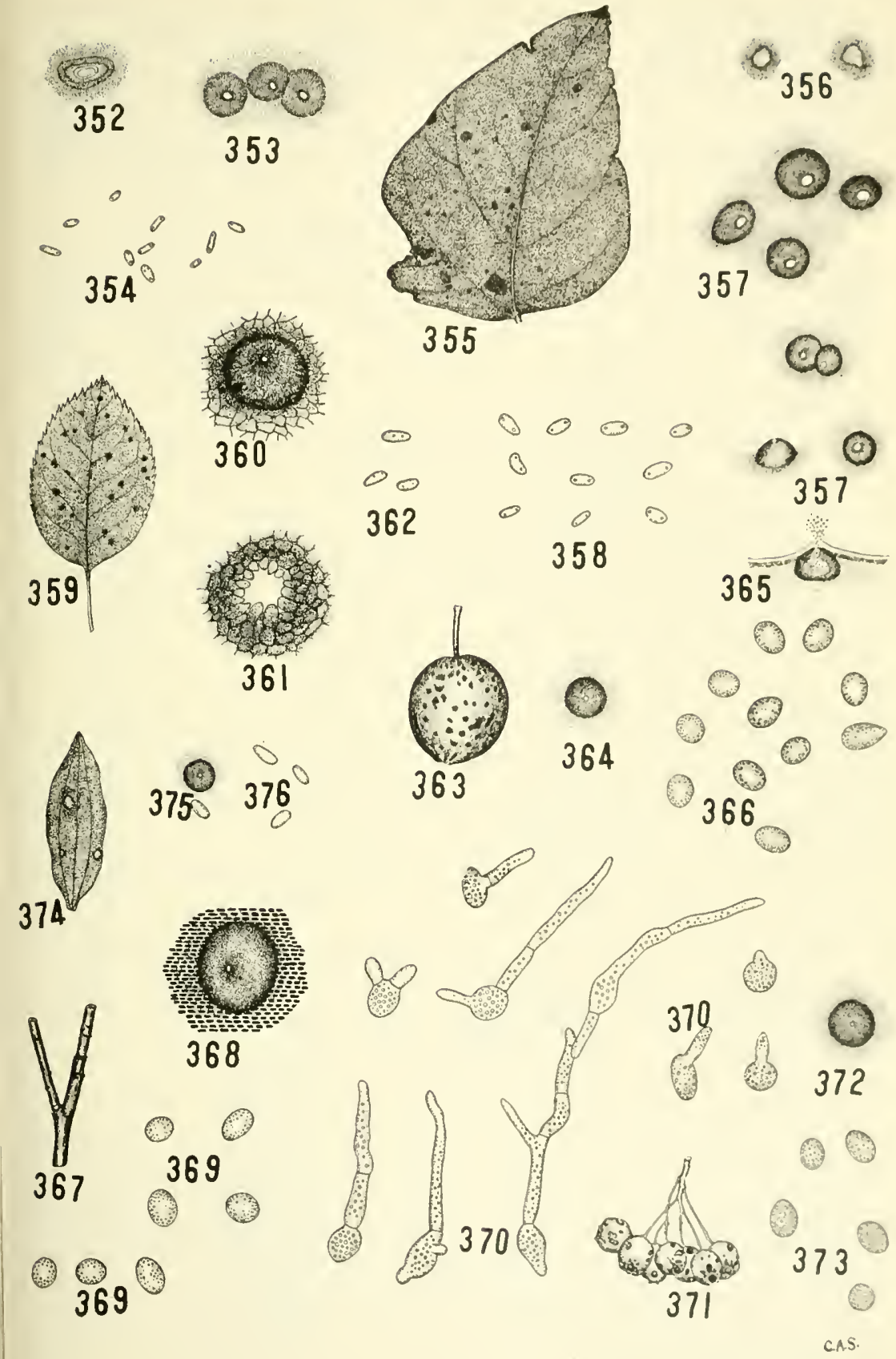


Phyllosticta tenerrima E. \& E.-On the leaves of Saponaria officinalis. Causes whitish to light brown spots with dark borders. Pycnidia 60-100 $\mu$ in diameter, ostiolate, spores hyaline, 4-6 $\mathrm{x}$ 2-2.5 $\mu$.

374. Infected leaf of Saponaria officinalis. 375. Pycnidium, 2/3. 376. Spores, $1 / 12$.

Phyllosticta viole Desm.-On the leaves of pansies and violets. Causes white, circular spots. Pycnidia numerous, very small, brown; conidia very small, hyaline, subcylindric to oval, and about $10 \mu$ long.

377. Portion of infected leaf of pansy. 378. Pycnidia, 2/3. 379. Spores $1 / 12$.

Pinoma batatæ E. \& H. (=Diaporthe batatatis Harter \& Field, page 60).

Piioma beta* (Oud.) Fr.-On the leaves and roots of the beet. Causes blackening and dying of the leaves, beginning with the younger beet leaves, and a "damping off" of the seedlings. Pycnidia over dead parts, small, more or less spherical, 125-635 $\mu$ in diameter; spores 3.8-9.4 x 2.6-4.3 $\mu$.

380. Pycnidium, 2/3. 381. Spores, 1/12.

Pinoma colutex S. \& R.-On the leaves of Colutea aborescens. Causes irregular confluent, gray spots with narrow dark brown borders. Pycnidia grouped, lenticular, brown, ostiolate; spores ovate-oblong to ovate, hyaline, $6-8 \times 2.5-3.2 \mu$.

382. Infected leaf of Colutea arborescens. 383. Pycnidium, 2/3. 384. Spores, 1/12, from two sources.

Phoma JAponica Sacc. - On the twigs of Kerria japonica. Causes irregular-shaped cankers. Pycnidia covered, minute, black, globose-depressed or oblong; spores fusoid, guttulate, hyaline, 6.6-10 × 3.3-4 $\mu$.

385. Infected twig of Kerria japonica. 386. Mycelium, 1/12. 387. Spores from twig, 1/12. 388. Spores from culture, 1/12.

Phoma mali Schulz \& Sacc.-On the fruit of the pear and apple. Causes a canker or dry rot. Pycnidia grouped or subcutaneous depressed, ostiole scarcely breaking forth; conidiophores filiform; spores oblong-ovate to oblong fusoid, $5-8 \times 2-3 \mu$.

389. Infected pear. 390. Spores, 1/12.

*Syn. Plwillosticta betce. 


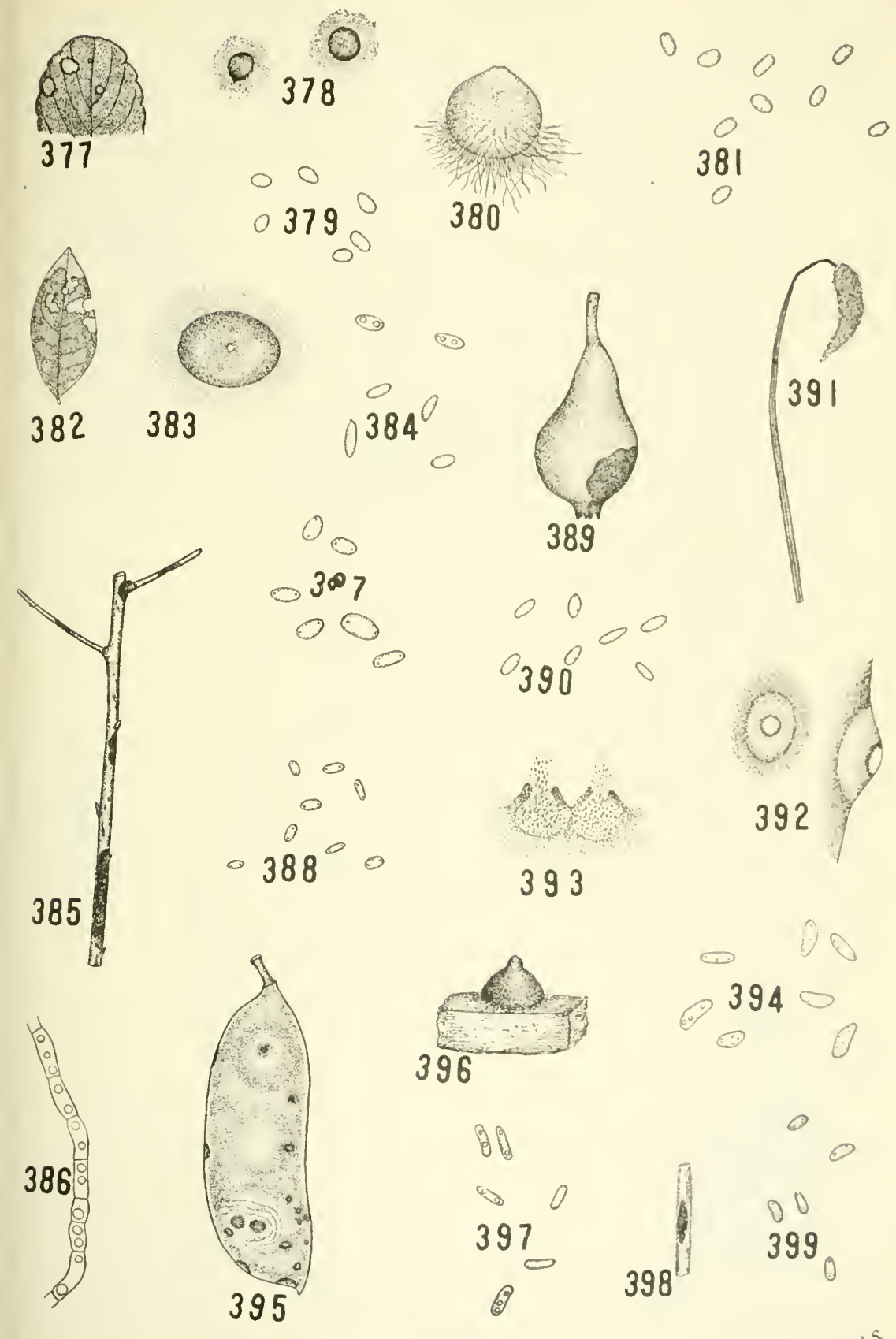


Phoma polygramata (Fr.) Sacc. var. plantaginis Sacc.--On the flowering shoot just below the inflorescence of Plantago lanceolata. Causes a drooping and death of the diseased parts, which frequently fall away. No stroma present. Pycnidia minute, numerous, globose, depressed, smooth, light brown. Spores numerous, oozing in whitish tendrils, ovate or irregular, hyaline, $6-9 \times 2-3 \mu$.

391. Infected inflorescence of Plantago lanceolata. 392. Pycnidium, 2/3. 303. Cross-section of same, 2/3. 394. Spores, 1/12.

Phoma sebcircinata E. \& E.-On the pods of the lima bean. Causes brownish or black spots. Described in Proc. Phil. Acad. Sci. (1893), p. 158, as follows: "Pycnidia subcuticular, $70-90 \mu$ diameter, sublenticular, subconfluent, ostiolate, membranaceous, black, subcircinately arranged in large $(1 \mathrm{~cm}$.) circular, faintly zonate spots, finally spreading and occupying the entire surface of the pods. Spores oblong-elliptical, hyaline, 2 guttulate, $5-6 \times 2-2.5 \mu$, on simple basidia rather longer than the spores."

We have also found a Phyllosticta on the leaves always associated with the $P$. subcirinata of the pods. They are probably the same organism.

395. Infected bean pod. 396. Pycnidium, 2/3. 397. Spores, 1/12

Phoma thapsi E. \& E.-On the living stems of Verbascum thapsus. Causes elongated, conspicuous, brown spots. Pycnidia papilliform, ostiolate and piercing the blackened epidermis; spores oblongelliptical, ends obtuse, 2 -guttulate, $5-6 \times 2.5 \mu$.

Note:- Spore measurements almost the same as Phyllosticta verbasicola but the pycnidia are shaped differently and the spores are larger and 2-guttulate.

398. Infected stem of Verbascum thapsus. 399. Spores, 1/12

Phoma uricola V. C. (= Guignardia bidwellii (E.) V. \& R., page 44).

Spharonema fimbriatum (E. \& H.) Sacc.-On the roots and stems of the sweet potato. Causes rots of both. Pycnidia black, base globose, $96-224 \mu$ in diameter and embedded in the tissues of the host, beak very long projecting from host, 395-608 $\mu$ long. 24-34 $\mu$ at base, $14-20 \mu$ at apex, the tips tapering and on maturity breaking into long, slender, hyaline fimbriations; prcnidia spores, globose or somewhat angular, hyaline, 5-9 $\mu$. Nycclium 2-6 $\mu$ in dianeter. frequently septate, giving rise to specialized hyphæ or conidiophores hearing two types of conidophores; the one olive-brown, thickwalled, globose to pear-shaped, $12-19 \times 6-13 \mu$, formed by constric- 
Parasitic Fungi of New Jersey
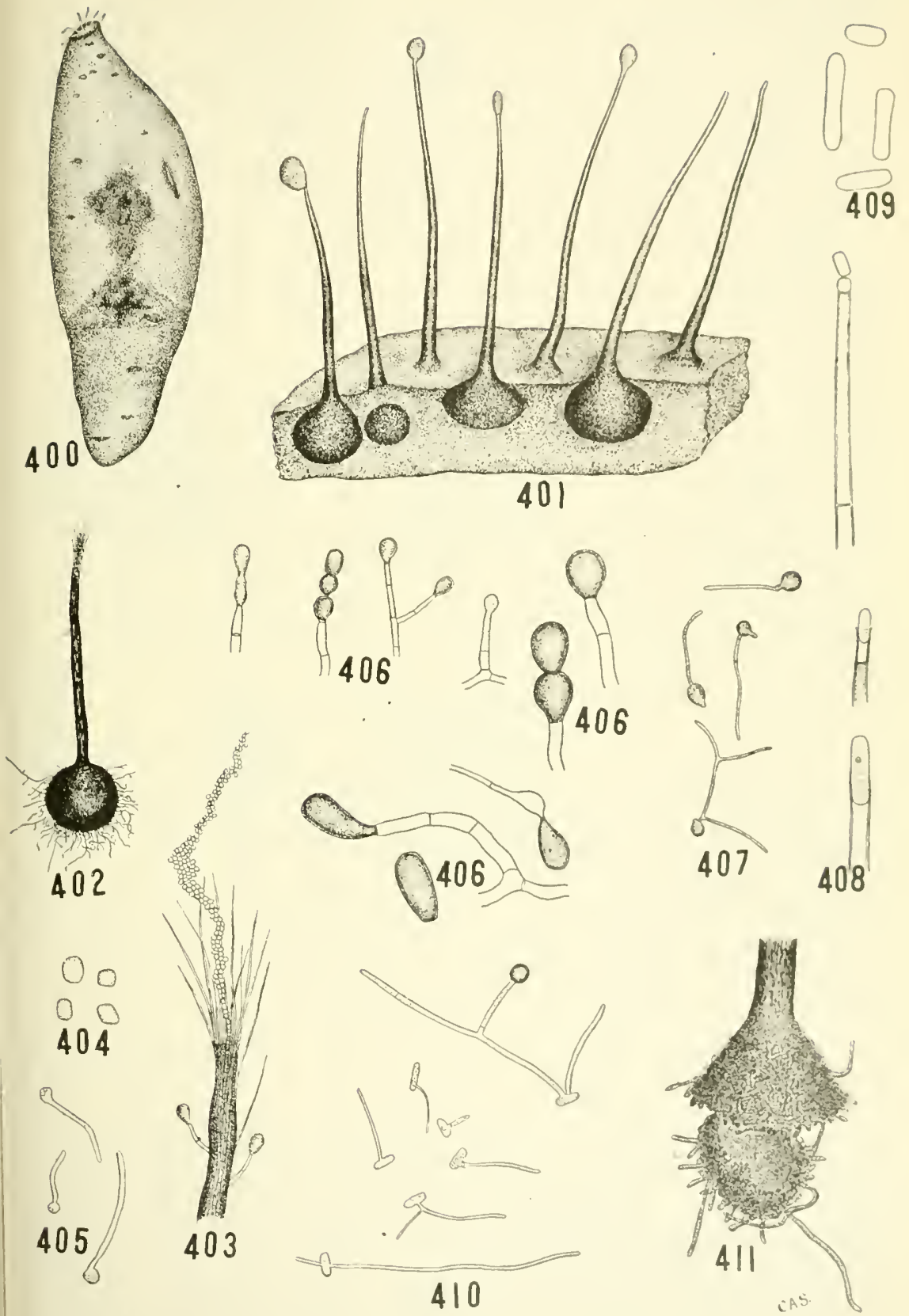
tion, and the other internally as hyaline, thin-walled, oblong-cylindric, endo-conidiospores, narrow in central part, 16-30 x 4-9 $\mu$.

400. Infected sweet potato. 401. Pycnidia embedded in the surface tissue of the sweet potato. 402. Mature pycnidium, 2/3. 403. Tip of same, 1/6. 404. Pycnospores, 1/12. 405. Same, germinating, 1/6. 406. Chlamydospores, 1/6, 1/12. 407. Germinating chlamydospores, 1/6. 408. Endoconidiophores with emerging endoconidia, 1/6. 409. Endoconidia, 1/12. 410. Endoconidia germinating, 1/6. 411. Base of immature pycnidium broken open, 1/6.

Vermicularia circinans* Berk. - On the scales of bulbs of white onions. Spots usually orbicular; pycnidia concentrically arranged, very small and covered with long spines; conidia cylindrical, elongated, curved, rounded at the tips.

412. Infected onion bulb. 413. Pycnidium, 2/3. 414. Bristles, 1/12. 415. Bristles arising from pseudoparenchyma, 1/12. 416. Spores, 1/12.

Vermicularia dematium (Pers.) Fr.-On Polygonum aviculare and also reported on asparagus and in Europe on ginseng. Pycnidia conic and depressed, erumpent, superficial, frequently confluent, $80-120 \mu$, more or less covered with black spines with pale tips measuring $150-200 \times 5 \mu$; conidia, elongated, cylindrical, slightly curved, rounded tips, $20 \times 4-6 \mu$. Usually a saprophyte but frequently a parasite.

417. Pycnidium, 2/3. 418. Sporcs, $1 / 12$.

Fusicoccum viticolum Reddick (= Cytosporella viticolum Sh.). On stems and fruits of grapes. Causes the "dead arm" disease of the stems resulting in the wilting and dying of the vine; also causes a rotting of the ripe or nearly ripe fruit which is very similar to the black rot (Guignardia bidwellii). Pycnidia, small, brown and of many chambers, ostiolate but frequently rupturing. Spores emerging in black tendril-like masses, hyaline or smoky, non-septate, more or less fusoid, sometimes curved, 6.6-13.3 × 3-6.3 $\mu$.

419. Infected cane of grape showing spore tendrils. 420. Cross-section of pycnidium, 2/3. 421. Same, 1/12. 422. Spores, 1/12 from two sources. 423. Germinating spores, 1/12.

Phomopsis vexans (Sacc. \& Syd.) Harter $i=$ Phvllosticta hortorum Speg., page 66).-On the leaves, stems and fruit of the eggplant. Causes leaf spot, stem and fruit rots. Pycnidia loosely grouped, black, beaked, flattened or irregular in shape, buried but hecoming erumpent, 60-200 $\mu$ broad on leaves and stem, 120-350 $\mu$ broad on fruit; conidiophores simple, short, straight or slightly

\footnotetext{
*Reported by J. C. Walker as Colletotrichum circinans (Berk.) Vogl. Mecting of the American Phytopathological Society, New York, Ober. 27-30, 1916.
} 
Parasitic Fitngt of New Tersey

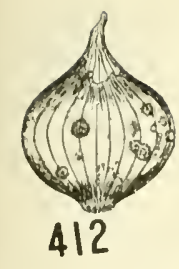

415

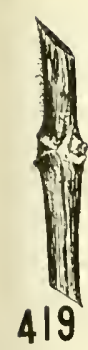

$\infty \varnothing$

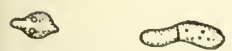

(1)
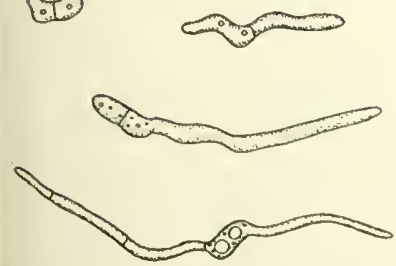

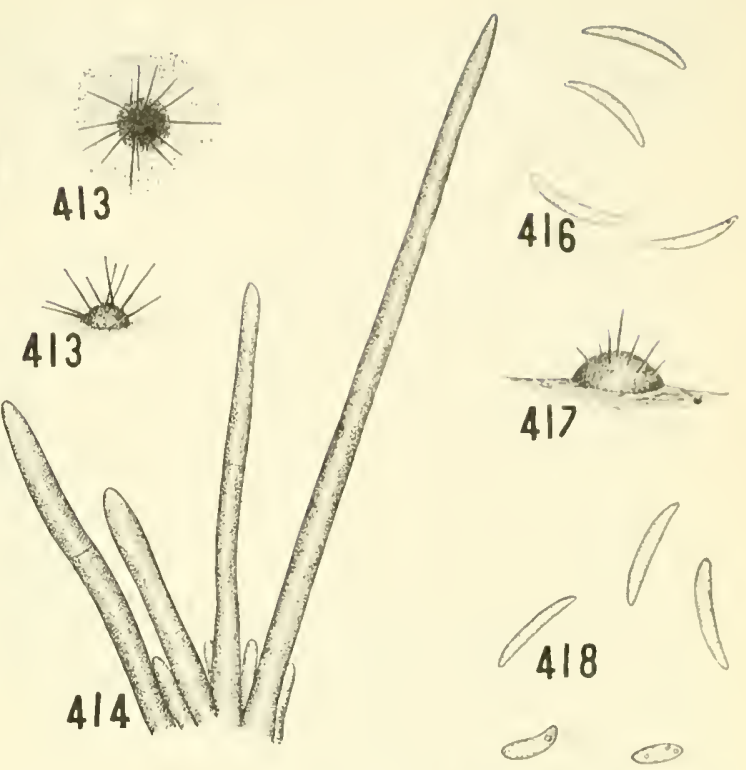

-<smiles>[CH]1C=C1</smiles>

0<smiles></smiles>

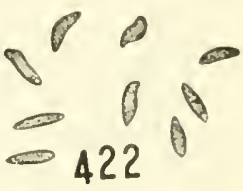

$\mathrm{f}^{\mathrm{\theta}}$
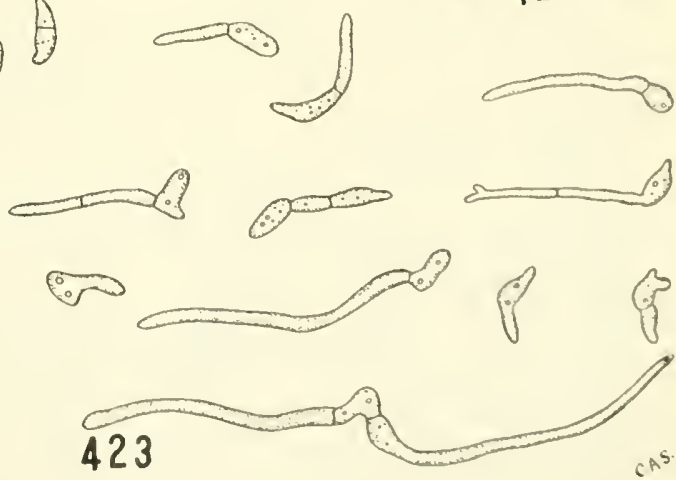
curved, hyaline, non-septate; pycnospores subcylindrical, somewhat acute, non-septate, 2-, occasionally 3-guttulate, hyaline, $5-8 \times 2$ $2.8 \mu$; stylospores filiform, curved, rarely straight, 13-28 $\mu$ long.

424. Pycnidium, 2/3. 425. Cross-section of same, 2/3. 426. Pycnospores, 1/12. 427. Stylospores, 1/12.

DothiORELla MIORI Berl.-On the twigs of mulberry. Causes cankers and a dying of the twigs. Pycnidia grouped, imbedded in the stroma, scarcely papillate, dark; conidiophores broadly filiform, hyaline, guttulate, $28-30 \times 3-4 \mu$; spores ovate to oblong, walls thick, guttulate, hyaline, non-septate, 19-28 x 15-16 $\mu$.

428. Cross-section through stroma showing pycnidia, 2/3. 429. Spores, 1/12.

Dothiorella sp. (= Botryosphaeria ribis G. \& D., page 62).

Sph eropsis Cydoniz C. \& E.-On the leaves and twigs of $C y d o-$ nia japonica. Causes reddish-brown leat spots and twig cankers. Pycnia immersed and punctiform; spores, brown, elliptical, 20-22 $\mathrm{x}$ $9 \mu$. We found what appeared to be the same species on Amelanchier. We believe that this is $S$. malorum.

430. Spores from Cydonia japonica, 1/12. 431. Spores from Amelanchier sp., $1 / 12$.

ShPæropsis JUxiperi Peck.-On the bark and leaves of Juniperus stricta. Pycnidia, black, grouped, erumpent, many small 230$275 \mu$ in diameter, spores oblong or ellipsoid, 20-23.5 x 11.5-13.5 $\mu$. Also reported on J. virginiana.

432. Spores, $1 / 12$.

SPHжROpsts MORI Berl.-On twigs of mulberry. Causes small cankers. Pycnidia sparse, or somewhat grouped, dark, globose, embedded in a fissure, collapsing, short ostiolum, conical, 1/3-1/2 $\mathrm{mm}$. in diameter; basidia hyaline, short and rather broad; spores oblong-ovate, base attenuated. deeply olivaceous, $15-18 \times 10-2 \mu$.

433. Spores, $1 / 12$.

SPH ÆROPSIS RUBiCOLA C. \& E.-On raspberry canes. Causing cankers. Pycnidia dark, subgregarious, erumpent, invisible until exposed by the splitting of the epidermis; spores brown, oblong, elliptical, $25-30 \times 10 \mu$.

434. Spores, $1 / 12$.

SPH eropsis staphylex Brun. - On twigs and fruit pods of Staphylea trifolia. Causes cankers and spots. Pycnidia scattered, minute, globose; spores ovoid or oblong, brown, continuous, 20-30 x 9-11 $\mu$. 


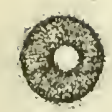

424

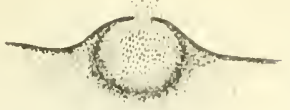

425
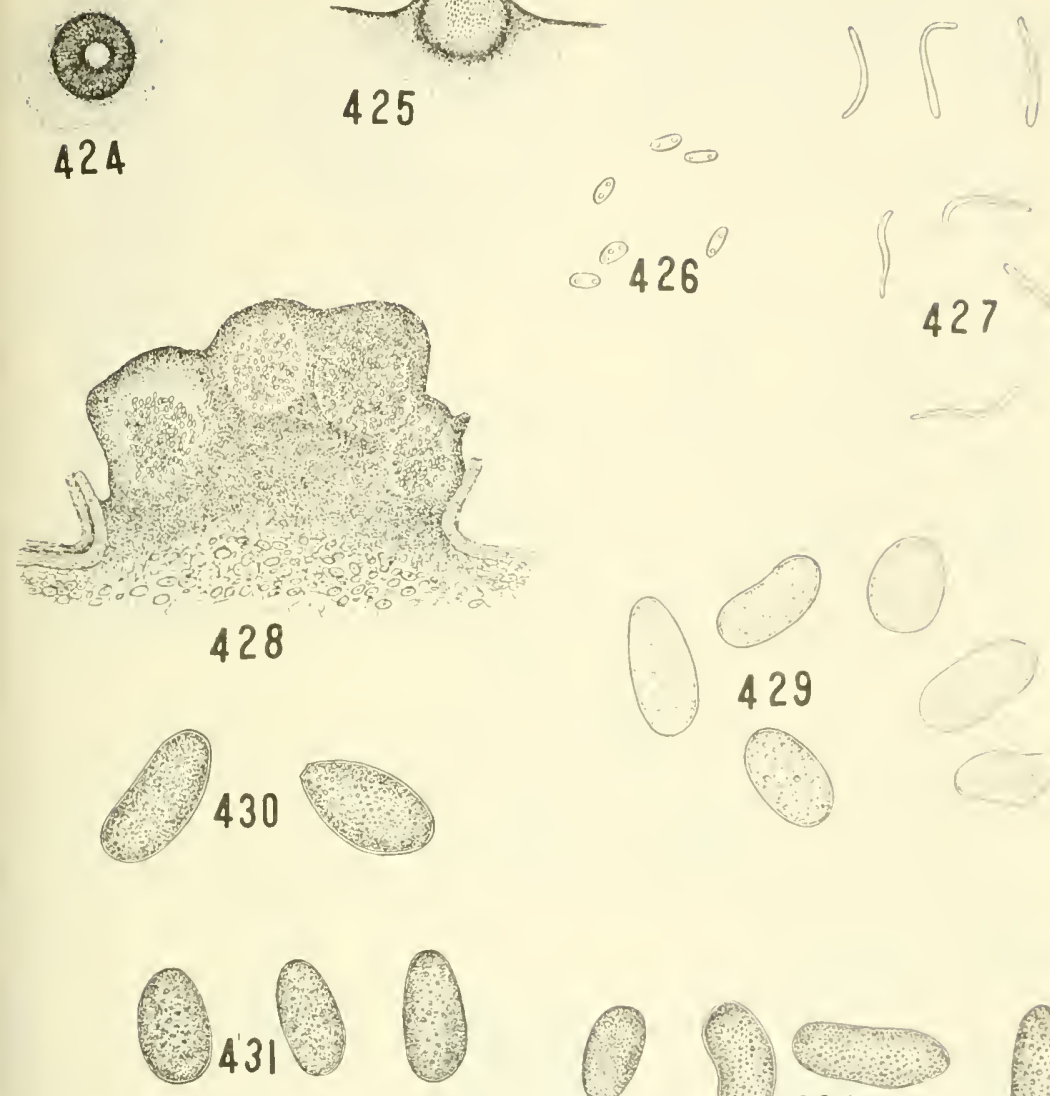

428

430

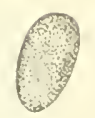

0
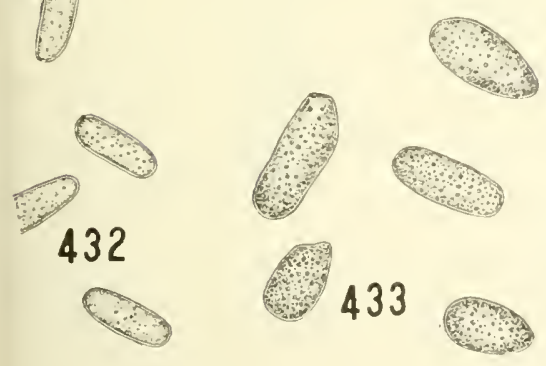

433
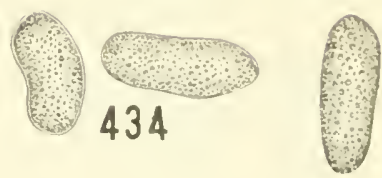

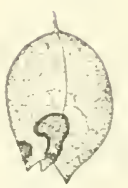

435
427

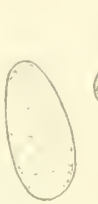

429
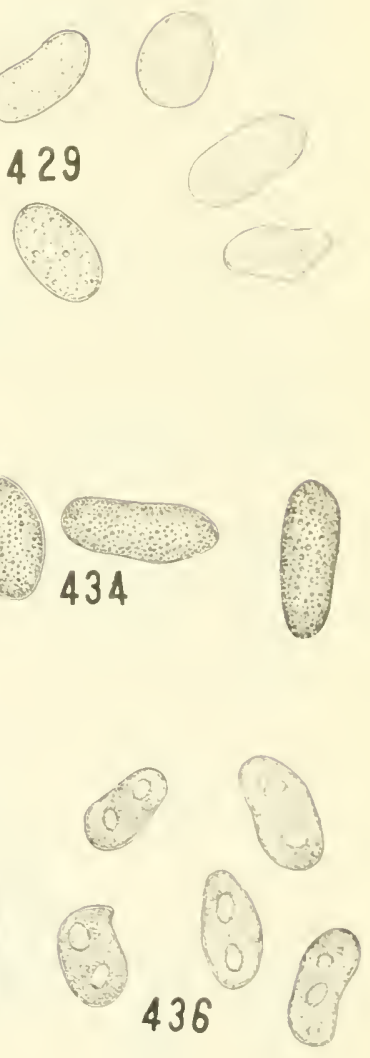
Spharopsis malorum Peck. (= Physalospora cydonia, page 46).--On apple, quince, pear and hawthorne. Causes cankers on twigs, branches and sometimes on the trunks; the black rot of the fruits and a spotting of the leaves. The pycnidia somewhat variable and more abundant on the fruit than on stem cankers. They may be simple or compound, erumpent, surrounded by the broken epidermis, $200-460 \times 200-720 \mu$.

- 437. Infected fruit of apple. 438. Infected branch ot apple. 439. Spores from apple fruit, 1/12. 440. Spores from quince, 1/12. 441. Spores from flowering crab, 1/12. 442. Spores from apple twig showing Diplodia character, $1 / 12$.

Note:- IVe have found what appears to be $S$. malorum on the young shoots of the peach. These cankers originate as small brown spots, enlarge, become irregular in outline, depressed and split lengthwise. The twigs are frequently bent and in advanced stages a gum is exuded. Pycnidia numerous, erumpent, ostiolate, black, spores oblong to ovate, sometimes truncate at point of attachment, $18.8-28.2 \times 11.6-13.3 \mu$.

Note:-Bartholomew's "Fungi Columbiani" has specimens 1590 labelled Spharopsis persica E. \& B. in which the spores are 2-celled and apparently belong to Diplodia persica Sacc. Hesler reports the ascogenous form on Hamamelis virginiana L. and Qurcus alba L. (See Phytopathology, v. 3, p. 290-295 (1913) and Cornell Univ. Agr. Exp. Sta. Bul. 379.)

443. Cankers on peach twigs. 444. Pycnidium, 2/3. H5. Spores, 1/12.

SPh жropsis SYring.e (Fr.) Peck \& Cke.-On the leaves and twigs of the Syringa rulgaris. Causes more or less frequently confluent spots. Pycnidia, black, grouped, slightly erumpent, subelliptical, depressed, rugulose, ostiolium, delicate; spores brown, oblong, $2-24 \times 10-11 \mu$.

446. Infected leaf of Syringa vulgaris. 447. Spores, 1/12. 
Coniothyrium Concentricun (Desm.) Sacc.--On the leaves of Incca and Agave, causing spots and dying of the tips. Spots circular or oval, or irregular, frequently confluent, yellowish, ashy, surrounded by a broad, dark, regular to irregular border; pycnidia concentrically depressed, dark, spores globose to ovoid, hyaline, b:coming yellowish and finally fuliginous, $4-5 \times 3-4 \mu$.

48. Infected tip of Yucca leaf. 449. Spots on the leaf of Agava sp. 450. Pycnidium, 2/3. 451. Pycnidia with spore tendrils, 2/3. 452. Cross-section of pycnidium from Yucca, 2/3. 453. Spores from Yucca, 1/12. 454. Spores from Agava, 1/12.

Coniothyrium FUCKeli Sacc. (= Leptospharia coniothyrium (Fcl.) Sacc., page 48).--On raspberries and roses. Causes a blighting and dying. The bark peels from the diseased part showing the small black pycnidia. (Pycnidia will also form on cut surfaces of canes in the moist chamber.) Pycnidia scattered, subcortical. erumpent globose-depressed, $180-200 \mu$; conidia numerous globose or slightly elliptic, those on raspberry measuring $2.5-4.4 \times 2-3 \mu$. those on rose measuring $3-5 \times 2-3.3 \mu$.

455. Infected cane of rose. 456. Pycnidium from leaf with emerging spores, 1/12. 457. Spores from same, 1/12. 458. Germinating spores, 1/12. 459. Pycnidium from leaf, $2 / 3$. 460. Spores from same, 1/12. 461. Pycnidia from cane, 2/3. 462. Cross-section of same, 2/3. 463. Same, 1/12. 464: Hymenium from same, 1/12. 465. Spores from same, 1/12. 466. Germinating sureres, $1 / 12$.

Coniothyrea olvaciey Bon. grandiflorac Sace. - On the leares of magnolia. Causes gray to brown circular or almost circular, sometimes irregular spots with definite margins, $1-5 \mathrm{~mm}$. in diameter. Pycnidia on the lower surface, globose, dark, about $100 \mu$ in diameter; spores oblong or elliptical, olive-brown, 5-7 $x$ $3-4 \mu$.

\section{Spores, $1 / 12$.}

Coxiotimpium Platani Sacc. - On the under surface of the leaves of sycamore. Causes brown blotches visible on both surfaces. Pycnidia black, globose, erumpent. Spores very small, olivaceous to brown, unicellular, oral or nearly spherical, 3-3.5 $\mathrm{x}$ $2-3 \mu$.

468. Spores, $1 / 12$. 
Parasitic Fungl of New Jersey
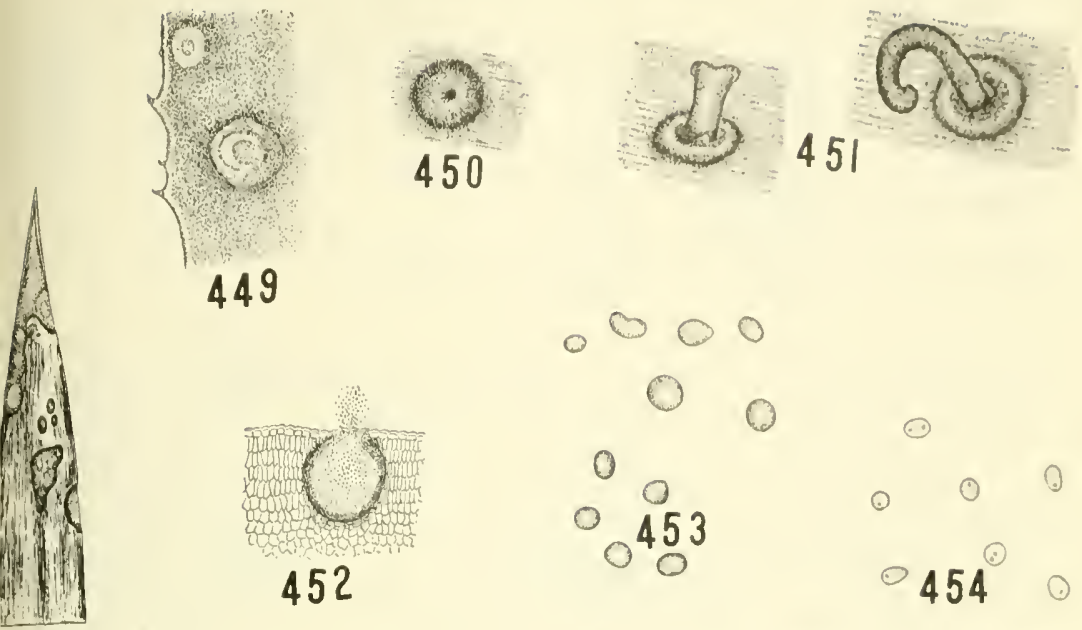

448

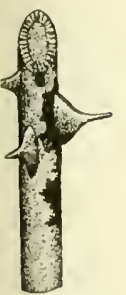

455
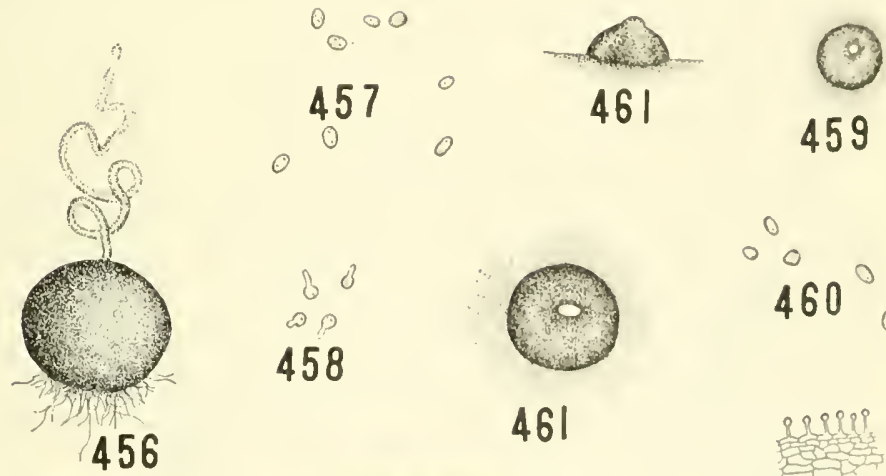

459

458

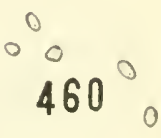

461

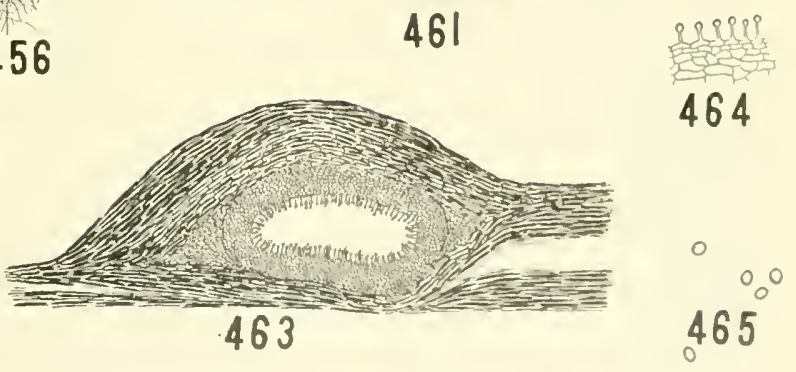

0

$467^{\circ}$

0

$468^{\circ}$

$8 \& 0$

0

(1)

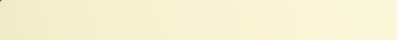

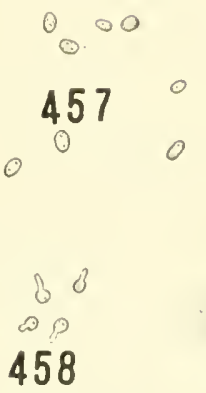


Ascochyta ALtheina Sacc. \& Bizz.-On the leaves of the hollyhock. Causes more or less circular, brownish spots, often with yellowish margins. Pycnidia brown, numerous, ostiolate; spores emerging in white tendril-like masses, ovate to oblong, more or less rounded at both ends, 1-septate, somewhat constricted at septum, hyaline, $6-10 \times 2.8-4 \mu$.

469. Leaf spot. 470. Pycnidium, 2/3. 471. Immature and mature spores, $1 / 12$.

Ascochyta LETHALIs* E. \& B. (= Mycospharella lethalis Stone, page 44).-On stems and petioles of Melilotus officinalis. Causes peculiar irregular, dirty white, slightly raised brownish border, about 2-3 mm. in diameter. Pycnidia numerous, loosely grouped, semi-erumpent, smooth, orbicular, convex, becoming concave, brownish to black, ostiolate, $50-120 \mu$ in diameter; spores oblong, cylindrical, obtuse at both ends, usually 1-, occasionally 2 septate, or non-septate, or uni- or bi-septate, slightly constricted, hyaline, $10-17 \times 3.5-4.5 \mu$.

472. Infected stem of Melilotus officinalis. 473. Pycnidia, 2/3. 474. Spores, 1/12.

Ascochyta Lycopersici Brun. - On the foliage of greenhouse tomato plants. Causes small brown, circular, spots which gradually become larger, sub-circular or irregular and grayish, reddish or brown in color and marked with delicate, black, more or less irregular concentric circles somewhat similar to the spots caused by the early blight (Macrosporium solani E. \& M.). Pycnidia few, minute, black; conidiospores oblong, 1-septate, constricted at the middle, hyaline, $8-10 \times 2.5 \mu$.

475. Infected tomato leaf, 476. Pycnidia, $2 / 3$ 477. Cross-section of pycnidium, 2/3. 478. Spores, 1/12.

Ascochyta RHEI $\uparrow$. \& E.-On the leaves of rhubarb. Causes reddish-brown, concentrically-zoned spots about $1 \mathrm{~cm}$. in diameter. Pycnidia brown, loose, beaked; spores oozing out in tendril form, straight or curved, oblong-ovate, hyaline, 1- or 2-celled, constricted, variable in size, the largest measuring $14.4 \times 3.5 \mu$.

479. Pycnidium, 2/3. 480. Spores, 1/12.

Ascochyta PIsi Lib. (= Mycosphcerella pinoides B. \& B., page 44).-On leaves, fruit, and stems of cultivated peas. Causes circular, yellowish spots of various sizes and brown margins. Pyc-

*Syn, A. Caulicola Lamb.

†Syn. Phyllosticta thei. 
nidia central, black, 5-7 $\mu$; spore mass pink to flesh-colored, conidia oblong, slightly constricted at septum, 12-16 x 4-6 $\mu$.

481. Infected stem and leares. 482. Infected pod. 483. Pycnidium, 2/3. 484. Spores, 1/12. 485. Germinating spores, 1/12.

Ascochyta Viciz* Lib.-On the leaves of Ticia. Causes leaf spots. Spots circular, reddish to orange red, margins elevated. Pycnidia minute-clustered, black, 90-100 $\mu$; spores oblong, obtuse, $12-15 x+-5 \mu$, exuding in white mass.

486. Infected leaflets and fruit pod of cultivated vetch. 487. Pycnidia, 2/3. 488. Spores, 1/12.

Darluca filun (Biv.) Cast. - On Uredinia sori. Pycnidia grouped, small conical to globose, ostiolate, dark, spores oblong fusoid, straight, 1-septate, usually slightly constricted, hyaline.

489. Pycnidia in sorus of Puccinia sp., 2/3. 490. Cross-section of leaf showing pycnidium in sorus, 2/3. 491. Pycnidium remored from host, 2/3. 492. Spores, $1 / 12$.

Actinonema rose (Lib.) Fr. (= Diplocarpon rose Wolf, page 34).-On the leaves of the rose. Causes black spots of irregular sizes and with radiating boundaries, frequently confluent and sometimes corering the entire leaf; pycnidia black, scattered or grouped; conidiophores short; conidia 2-celled, constricted, 18-20 × $5 \mu$.

493. Infected rose leaf. 494. Acervuli, 2/3. 495. Cross-section of same, 1/12. 496. Spores, $1 / 12$.

Note.-The apparent radiating hyphæ are in reality wrinkles on the cuticle. Therefore, this species should be placed in the genus Marsonina (Marsonia), Diedicke, H.-Die Abteilung Hyalodidymæ der Sphacrioideen. In Ann. Mycol., v. 10, 135-152 (1912).

Diplodia longispora C. \& E.-On the twigs of Quercus coccinea, Q. primus, Q. alba and Castanea dentata. Causes cankers, a blighting and leath of the infested parts. Pycniclia grouped, partly immersed, globose to sub-globose, ostiolate, dark-brown or black, 95-145 $\mu$; spores oral or ovoid, nften slightly smaller at one end, 1-septate, hyaline to yellow or dark-brown, depending on age, $29-35 \times 7-11 \mu$.

497. Pycnidia rupturing epidermis, 2/3. 498. Pycnidium and emerging spores, 2/3. 499. Conidiophores and immature spores in various stages of development, 1/12. 500. Immature spores, 1/12. 501. Maturc spores, 1/12.

*Probably the same as Ascochyta pisi [Stone, R. E.-The Life History of Ascochyta on some Leguminous Plants. In Ann. Mycol. v. 10, p. 56+-592 (1912). 1 
Diplodia PINeA* (Desm.) Kickx.-On the stems and needles of pine. Causes cankers on the stems and a dying of the needles. Pycnidia globose, papillate, erumpent, the papilla falling away at maturity. Spores oblong, dark brown, thick-walled, 1-septate when mature, occasionally 2 - or 3-septate, 35-40 x 16-18 $\mu$.

502. Cross-section of pine needle showing pyonidia, 2/3. 503. Cross-section of pycnidium in bark, 2/3. 504. Conidiophores and spo-es in various stages of development, 1/12. 505. Immiature spores, 1/12. 506. Mature spores with 1,2 and 3 septa, 1/12. 50\%. Cankers on stem showing speres.

Diplodia sapixea (Fr.) Fckl.-On the branches of Pinus syliestris. Pycnidia prominent, grouped, erumpent, globose, smooth, dark, osticlum in the form of a papilla; spores, ellipsoid-oblong, somewhat unequally one-sided, dark, 24-26 × $12 \mu$.

508. Mature and immature spores, $1 / 12$.

Stagoxospora CARPathica Baeuml.-On leaves of white clover (T. repens) and alfalfa. Causes small, circular or irregular spots which become dry and white or ashy-brown with dark, narrow margins. Pycnidia on both surfaces of leaf, sparse, globular, ostiolate, pale brown, 120-180 $\mu$ in diameter. Spores cylindrical straight, or occasionally slightly curved, flexuous, 1-celled, or 1-3 septate, sometimes constricted, $18 \times 3.5 \mu$; on clover, $6-15 \times 2.5-3.5 \mu$.

509. Infected leaf of Trifolium repens. 510. Pycnidia, 2/3. 511. Spores, 1/12. 512. Pycnidia from alfalia, 2/3. 513. Spores, $1 / 12$.

* Syrn. Spheria pinca. 

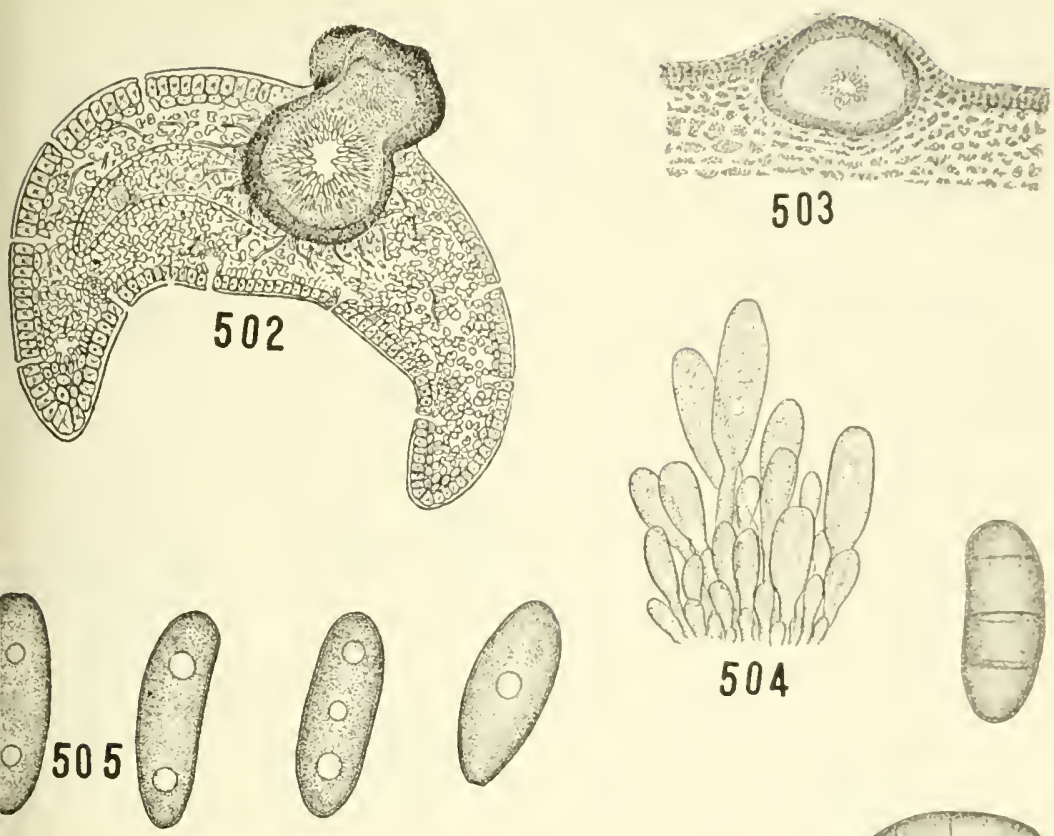

504
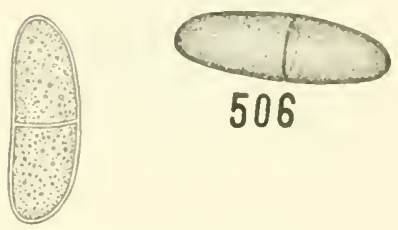

\section{8}
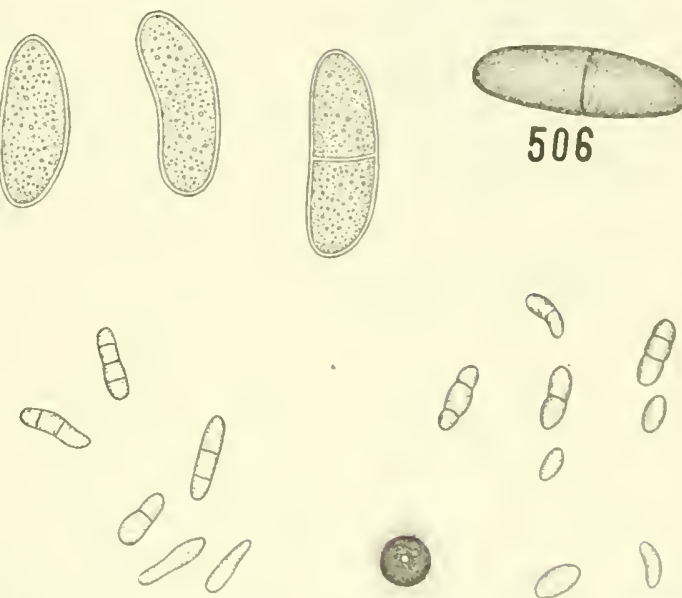

507
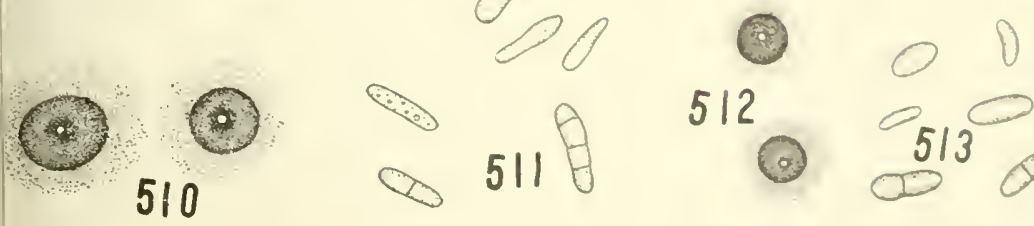

512

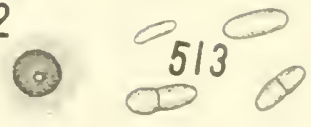


Septoria cerastii Rob. \& Desm. - On the leaves and stem of Cerastium vulgatum. Causes spots which are pale yellow, becoming ashy-gray at maturity. Pycnidia globose, lenticular, black ostiolate, $80 \mu$ in diameter; spores escaping in whitish tendrils, hyaline, long, straight or slightly curved, $30-40 \times 1 \mu$.

\section{Pycnidia, 2/3. 515. Spores, 1/12.}

Septoria chrysanthemi Allesch.-On the leaves of the Chrysanthemum. Causes brown spots of various sizes and frequently a dying of the margins. When severe the leaves wither and fall. Spots ochre-colored with dark margins; pycnidia globular with short beak; spores long, straight or slightly curved, hyaline, sometimes obscurely septate, $32-57 \times 1.5-2 \mu$.

516. Infected leaves of Chrysanthemum. 517. Pycnidia, 2/3. 518. Immature spores, 1/12. 519. Mature spores, 1/12.

Septoria convolvuli Desm.-On the leaves of Convolvulus arvensis. Causes circular, sometimes confluent, reddish-brown spots becoming smoky-brown and finally whitish. Pycnidia minute, brown erumpent; spores long, straight or slightly curved, 3-5 septate, 35$50 \times 1.5 \mu$.

520. Infected leaf of Convolvithus arvensis. 521. Pycnidia, 2/3. 522. Crosssection of pycnidium, 2/3. 523. Spores, 1/12.

Septoria cornicola Desm.-On the leaves of Cornus. Causes scattered, depressed, orbicular spots $100-110 \mathrm{~mm}$. with dark purple margins. Conidia cylindric, curved, obsolete $2-4$ septate, hyaline, $35-40 \times 2-2.5 \mu$.

524. Infected leaf of Cornus si. 525. Pycnidia, 2/3. 526. Spores, 1/12. 527. Germinating spores, 1/12. 
Septoria dianthi Desm.-On the leaves of cultivated Dianthus. Causes yellow, long, circular or irregular spots; pycnidia pearshaped, depressed, blackish, ostiolate; spores in tendrils, elongated, cylindrical, curved, 1-2 septate, one end slightly larger than the other, hyaline, $30-45 \times 4 \mu$.

528. Infected stems of Diantinus sp. 529. Pycnidia, 2/3. 530. Spores, 1/12.

Steptoria erigerontis B. \& C.-On the leaves of Erigcron sp. Causes dark-brown circular spots with raised margins, visible on both surfaces, sometimes confluent, $3-4 \mathrm{~mm}$.; pycnidia numerous, grayish-brown or black, erumpent, ostiolate, $63-105 \mu$; spores hyaline, filiform straight or slightly curved, attenuated at one end, non-septate, $30-45 \times 1-1.5 \mu$.

531. Infected leaf of Erigeron sp. 532. Pycnidium, 2/3 533. Spores, 1/12.

SEPTORIA LACTUCæ Pass.-On the leaves of lettuce. Causes irregular, angulated, brownish spots and frequently destroying the entire leaf. Pycnidia scattered, minute, punctiform and about $90 \mu$ in diameter. Conidia filiform, straight or curved, $25-30 \times 1.7-2 \mu$.

534. Pycnidia, 2/3. 535. Spores, $1 / 12$.

Septoria lobeliae Peck. - On the leaves of Lobelia inflata. Causes orbicular or oval, often confluent, dry, pale or light yellowishbrown spots sometimes with dark or browninsh-purple margins. Pycnidia on both surfaces, minute, numerous, dark, brown; spore tendrils white, spores hyaline, 1-3 septate, filiform, 17-27 x $1 \mu$.

536. Infected leaf of Lobe!ia inflatu. 537. Pycnidia, 2/3. 538. Spores, 1/12.

SEPTORIA LIQUidAMBARIS C. \& E.-On the leaves of Liquidambar styraciflua. Causes suborbicular brown spots about $1-2 \mathrm{~mm}$. in diameter. Pycnidia on the under side of the leaf, prominent, clustered, ostiolate, sub-globose, $80 \mu$ in diameter; spores hyaline, curved ends, 3-5 septate, $55-60 \times 3 \mu$.

539. Infected leaf of Luquidambaris styraciflua. 540. Spores, 1/12.

Septoria Lycopersici Speg.-On the leaves and stems of the tomato. Causes numerous small black spots followed by a yellowing, dying and falling of the entire leaf. Pycnidia scattered, prominent and membranous; conidia elongate, cylindric, many septate, $70-110 \times 3.3 \mu$.

541. Infected tomato leaf. 542. Cross-section of pycnidium, 2/3. 543. Spores, 1/12. 
Septoria Mrricice E. \& $\mathrm{IV}$.- On the leaves of Myrica cerifera. Causes rusty-brown frequently confluent spots about $3-6 \mathrm{~mm}$. in diameter on under surface of the leaf. Perithecia erumpent, black, conical and with broad opening at apex. Spores slender, curved, hyaline, 3-6 septate, $8-10 \times 1.25 \mu$.

54t. Infected leaf of Myrica cerifera. 545. Spores, 1/12.

Septoria rabali B. \& C. - On the leaves of Nabalus albus. Causes leaf spots. Spots, numerous, circular, oval or sometimes irregular and confluent, white and surrounded by broad purplish border; perithecia dark brown, globose, erumpent, 57-90 $\mu$; spores slender flexuose, 3 -septate when mature, $20-36 \times 2-2.5 \mu$.

546. Infected leaf of Mabalus albus. 547. Pycnidia, 2/3. 548. Spores, 1/12.

Septoria petroselini var. Apii. Br. \& Cav.-On celery. Causes more or less circular, sometimes angular, spots on the leaves and petioles. Spots on leaves about $1.5 \mathrm{~cm}$. in diameter, drab to brown, borders raised, frequently coalescing. Spots on petioles originate as water-soaked areas. Pycnidia simple or compound, globose or elliptical, 52-138 $\mu$; conidia crlindrical, fusiform, filiform or curved, one end subacute, the other cylindrical, septa faint, nearly hyaline, $19.2-57.7 \times 2.7-3.8 \mu$.

549. Infected leaf of celery. 550. Pycnidia, 2/3. 551. Spores, 1/12

Septoria Piricola Desm. (= Mycospharella sentina (Fr.) Schr., page 46).

Septoria polygororum Desm. - On leaves of Polygomum. Causes small, circular brown spots with dark borders; pycnidia minute, pale brown, erumpent, concave at maturity; spores filiform, 2-4 septate, hyaline, $25 \times 1 \mu$.

552. Portion of infected leaf of Polygonum sp. 553. Spores, 1/12.

Septoria PRUNelle* Ell \& Holw:-On the leaves of Prunella s'ulgaris. Causes dark brown or black spots of various shapes; pycnidia broad, prominent, scattered on upper surface of the spot, dark, smooth, 100-130 $\mu$; spores somewhat dark, clavate, narrow, multi-septate, $40-75 \times 1.5-2 \mu$.

554. Infected leaf of Prunella vulagris. 555. Pycnidia, 2/3. 556. Spores, $1 / 12$.

*Given in Saccardo, P. A., "Svilloge Fungorum," as Septoria brunella. 
Parasitic Fungi of Neiv Jersey

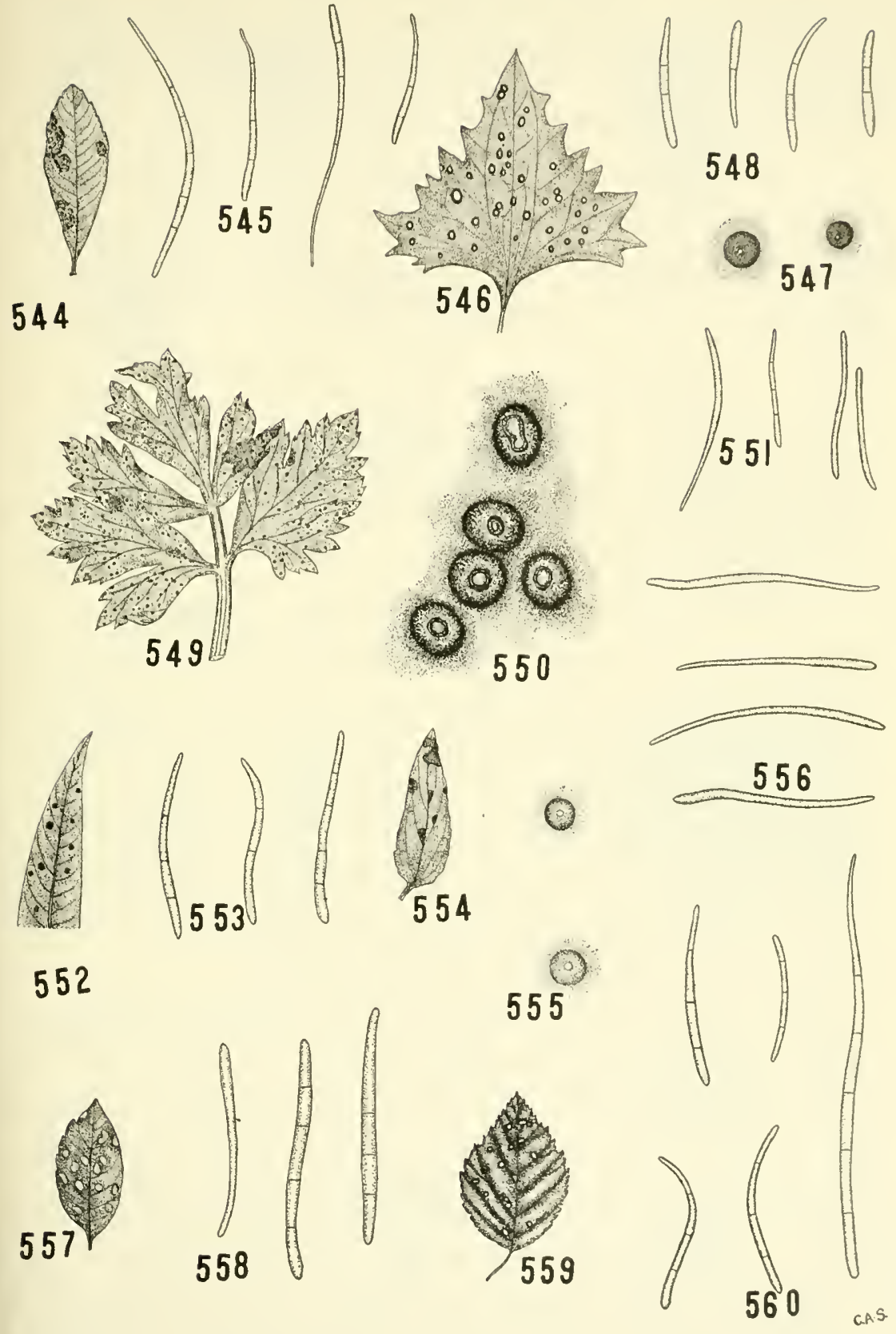


Septoria RHOINA B. \& C.-On leaves of Rhus copallina. Causes spots. Spots reddish brown, circular, ovate, sometimes confluent; pycnidia numerous, black on both surfaces of the leaf; spores long, slender, flexuose, few septate, $50-86.5 \times 3.3-6.3 \mu$.

557. Infected leaflet of Rhus copallina. 558. Spores, 1/12.

Septoria RUbi West.--On the leaves and stems of the species of Rubus. Causes small, circular, reddish-brown spots which become white with purple borders; pycnidia sparse, curved, brownish-black, depressed, erumpent; spores filiform, hyaline, 2-3 septate, 40-55 x $1.5 \mu$.

\section{Infected leaflet of raspberry. 560. Spores, 1/12.}

Septoria verbasicola B. \& C.-On the leaves of Verbascum blattaria L. Causes more or less circular, dry thin spots with broad, dark, purple borders and about 1-3 $\mathrm{mm}$. in diameter, Pycnidia few on a spot, ciustered, black, erumpent, $80-85 \mu$; spores byaline, filiform, curved, $20-40 \times 1.5 \mu$.

561. Infected leaf of $V$. blattaria. 562. Pycnidia, 2/3. 563. Spores, 1/12.

Melasmia acerina Lev. (= Rhytisma acerinum (Pers.) Fr., page 24).

Entomosporium maculatum Lev. (Fabraa maculata (Lev.) Atk., page 24).--On leaf and fruit of the pear and quince. Causes spots which are more prominent on the upper surface, circular, at first reddish with dark borders, in severe cases causing the leaves to become brown and fall; fruit spots are red, gradually becoming very black, and in severe cases cause the fruit to crack. Acervuli, black, sub-epidermal; conidia hyaline, $1 \mathrm{~S}-20 \times 12 \mu, 4$ cells in a group, stipe filiform, $20 \times 0.75 \mu$, the other cells with long setx.

56t. Infected leaf of pear. 565. Infected fruit of pear. 566. Infected lcaf of uince. 567. Cross-section of acervulus, 2/3. 568. Hymenium showing formation of conidia, 1/12. 569. Mature spores, 1/12.

Entomosporium tilumenii (Cke.) Sacc.-Causes small, dark, spots on the leaves of Cratagus oxyacantha. Probably the same as E. Maculatum Acervuli numerous, on both surfaces of the leaf, flattened, orbicular, roughened, often confluent, conidia $22 \times 9 \mu$.

570. Infected leaf of Cratagus sp. 571. Mature spores, 1/12.

Discosia artocreas (Tode) Fr.-On the canes of the raspberry; associated with the Coniothyrium fuckelii cankers. Pycnidia grouped, disc-shaped, black, shining, at first convex becoming depressed and ostiolate and finally collapsing; spores elongated, very clightly curverl, ends rounded, 3-septate. hyaline or yellowish, a 
Parasitic Fungi of New Jersey

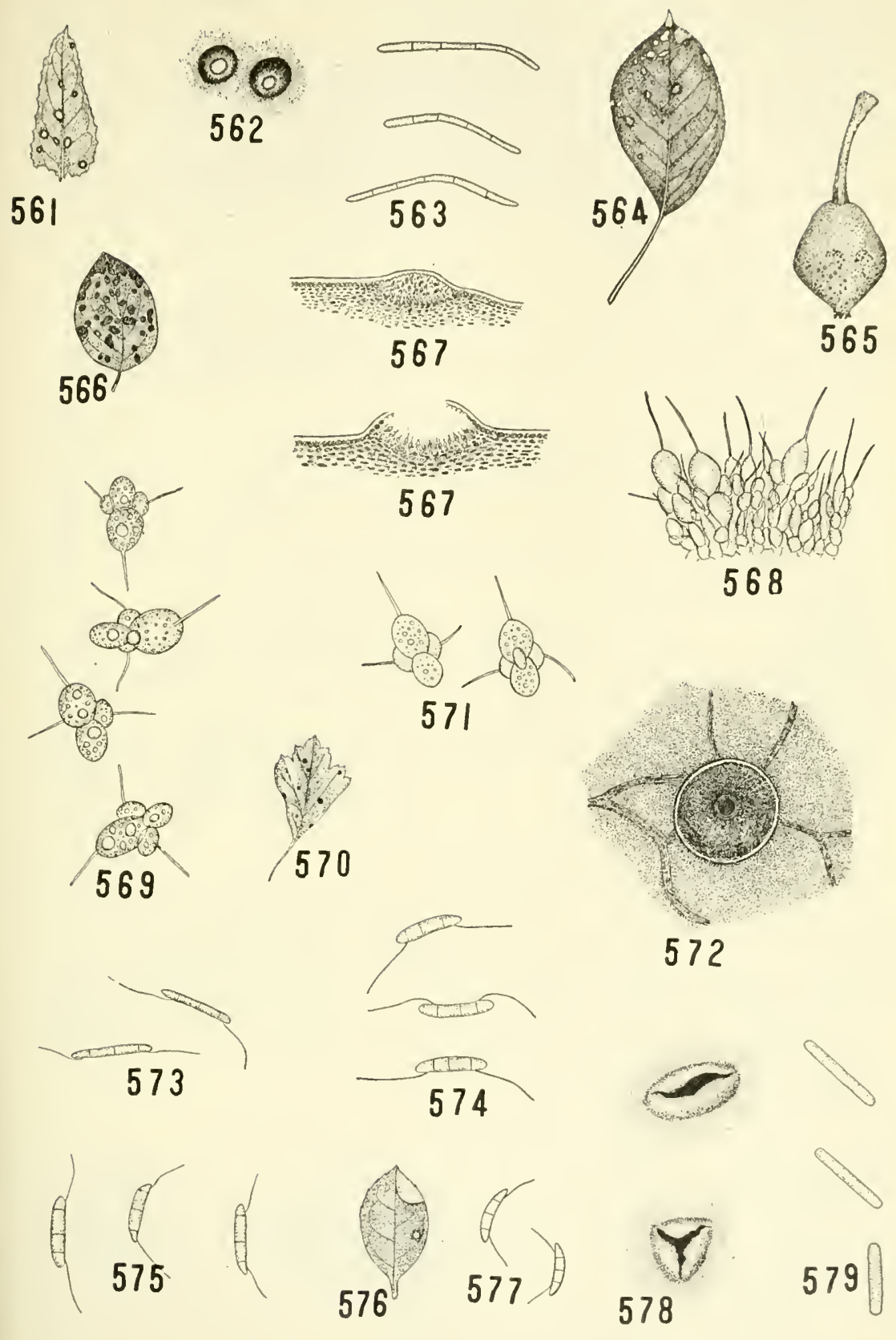

(4) 
large cilium arising laterally near each end, 14-22 × 2-3.5 $\mu$; cilia 10-15 $\mu$ long. Also occur on other hosts.

572. Pycnidium from rose leaf, 2/3. 573. Spores from same, 1/12. 574 . Spores from raspberry, 1/12. 575. Spores from Cercis candensis, 1/12.

Discosia maculicola Gerard.-On the leaves of Gaultheria procumbens. Causes dry and whitish spots with narrow, dark borders on both surfaces of the leaf. Pycnidia densely grouped, at first covered but becoming erumpent, 150-170 $\mu$; spores fusiform, slightly curved, obtuse ends, greenish hyaline to smoky-colored, 3-septate, 2 lateral cilia near the ends, $14-15 \times 3-3.5 \mu$; cilia $6-7 \mu$ long.

576. Infected leaf of Gauthuria procumbens, 1/12. 577. Spores, 1/12.

Sporonema oxycocci Shear.-On the leaves and rarely on the fruit of the cranberry. Pycnidia scattered or grouped, dark brown, under the epidermis which ruptures by an irregular or triangualr slit, the upper portion thin and disappearing early, 50-100 $\mu$ in diameter; spores on short ovoid sporophores, hyaline, cylindrical and obtuse, $17-19 \times 3-4 \mu$.

578. Pycnidia, 2/3. 579. Spores, 1/12.

Sporonema PUlvinatum Shear.-On the leaves of the cranberry. Pycnidia simple, dark brown, pulvinate, under the epidermis, $300-420 \mu$ in diameter by $100-150 \mu$ thick, sometimes collapsing, spores, pale greenish, yellow in masses, subelliptical, slightly curved, $6-8 \times 2-2.5 \mu$.

580. Spores, $1 / 12$.

Dothichiza popui.ea Sacc. \& Br.--On the twigs of the Carolina and Lombardy poplar. Causes cankers and a dying of the diseased parts. Pycnidia numerous, loosely grouped and covered by the epidermis, but becoming erumpent dark, globose, depressed, becoming irregular, 0.75-1 mm. in diameter ; spore in tendrils with a faint yellowish-brown tinge; spores globose-clipsoid, in many cases with one end pointed, hyaline, $10-12 \times 8-10 \mu$.

5\$1. Cross-section of pycnidia, 2/3. 582. Spores, 1/12.

RHABDospora RUBi. Ellis.-On the stems of the blackberry and raspberry. Pycnidia scattered, embedded in the tissues, subglobose, black, 100-195 $\mu$; conidia linear, irregularly curved, 5-septate, 40-45 × $3 \mu$.

583. Pycnidia in tissue of plant, 2/3. 584. Spores, $1 / 12$.

Glemosporium ampelopiaguar (Pass) Sacc.-On the fruit, leaf and cane of the grape. Causes the "bird's eye" rot of the fruit, more 

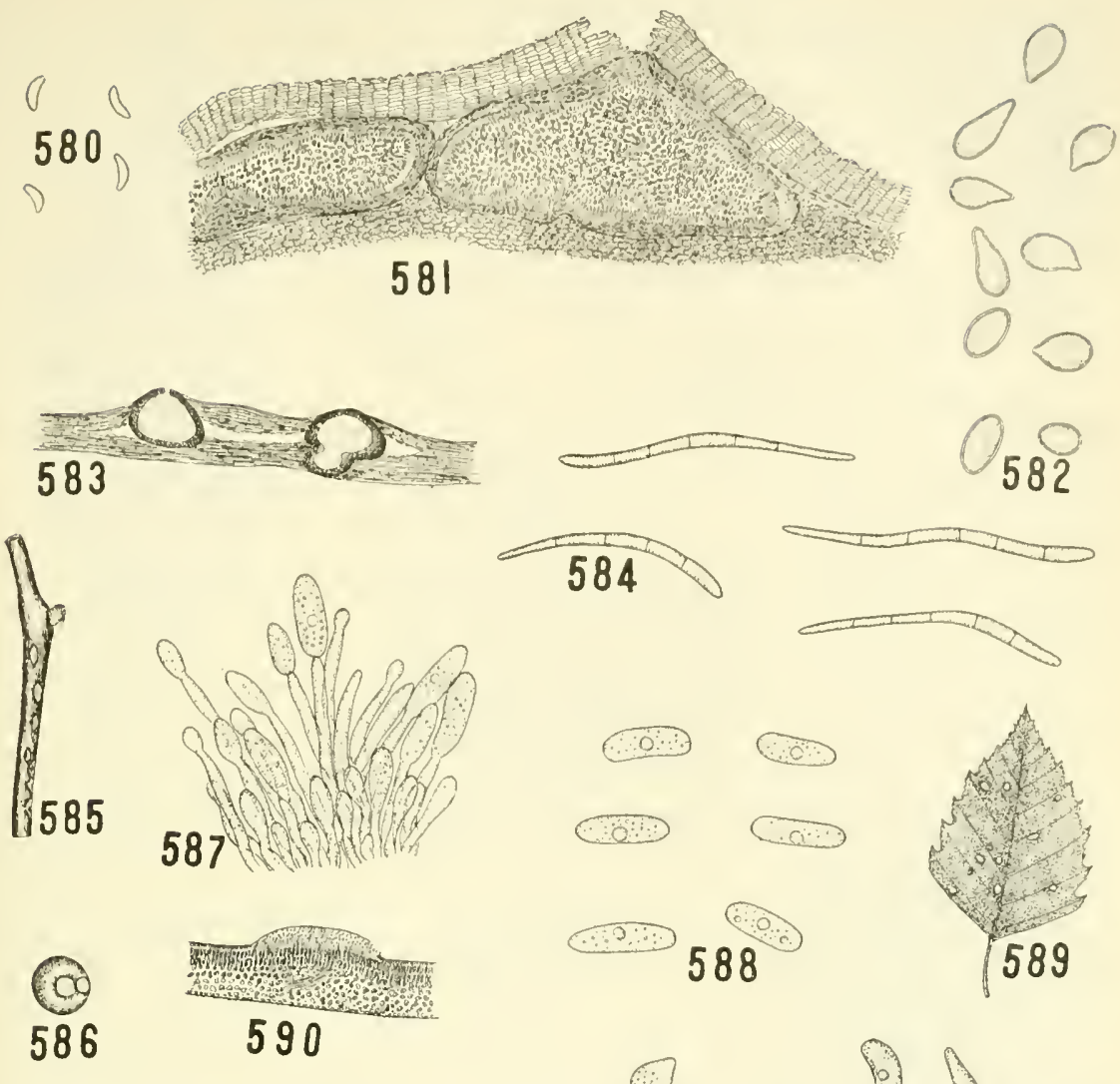

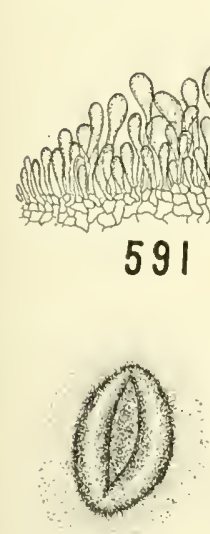

593

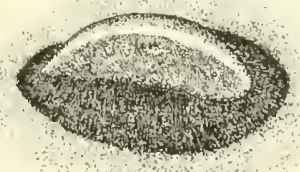

593

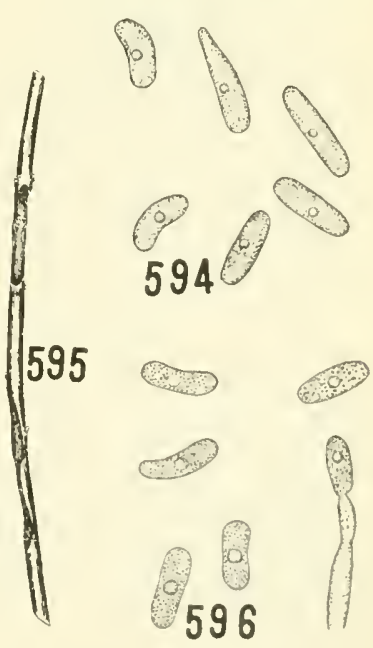


or less circular or oblong, sometimes confluent spots with white sunken centers and red margins on the leaf and stem. Spots frequently crack open. Acervuli most common on fruit and twigs, very small, grouped, sub-epidermal, spore masses pink, conidia, usually oblong with rounded ends, sometimes slightly curved, hyaline, 5-6 x $2-3 \mu$.

585. Infected grape cane. 586. Infected berry. 587. Cross-section through acervulus showing conidiophores and conidia in various stages of development, 1/12. 588. Spores, $1 / 12$.

Gleosporium betularum E. \& M.-On the leaves of the red birch (B. nigra). Causes more or less circular yellowish-brown spots with black borders about 2-3 mm. in diameter. Acervuli brown, 120-140 $\mu$. in diameter. Conidia, obovate, hyaline, $0-10.5 \times 6 \mu$.

589. Infected leaf of red birch 590. Cross-section of acervulus, 2/3. 591 . Same, 1/12. 592. Spores, 1/12.

Gleosporium cingulatum Atk. = Glomerella cingulata (Atk.) S. \& S., page 52).-On the leaves of Ficus elastica. Causes large spots and dying of the leaves. Acervuli numerous, black, erumpent, spore tendrils salmon-colored, broad and flat; conidia oblong, usually rounded at ends, sometimes slightly curved, hyaline, guttulate, $12-16.5 \times 3.3-5 \mu$.

593. Acerwuli on Ficus elastica, 2/3. 594. Spores, 1/12. 595. Infected twig of privet. 596. Conidiophore and conidia, 1/12.

Glceosporium Caryæ E. \& D. (= Gnomonia caryce IVolf, page 58).- On the leaves of the hickory. Causes a spotting and blighting. Spots suborbicular, reddish-brown on lower surface, $1 / 2 \mathrm{~cm}$. in diameter, frequently confluent with indefinite margins; acervuli on the lower surface, numerous, subcuticular, brown, 70-150 $\mu$ in diameter; conidia oblong, or allantoid, 1 -celled, $7-10 \times 1.5-2 \mu$. Spores develop in late summer or fall.

597. Infected hiciory leaflet. 598. Spores, 1/12.

Glgosporium CAULIVORUM Kirch.-On the stems of red clover. Causes peculiar cankers. Acervuli very small, punctiform, grouped, erumpent, more or less sunken; conidiophores cylindrical, stipitate and slightly longer than the conidia. Conidia, cylindrical to fusoid, straight or curved, ends obtuse or acute, hyaline, granular, $12-22 \mathrm{x}$ $3.5-5.2 \mu$.

599. Spores, $1 / 12$.

*Syn. Leptostromella elastica E. \& E. 
Parasitic Fungi of New Jersey
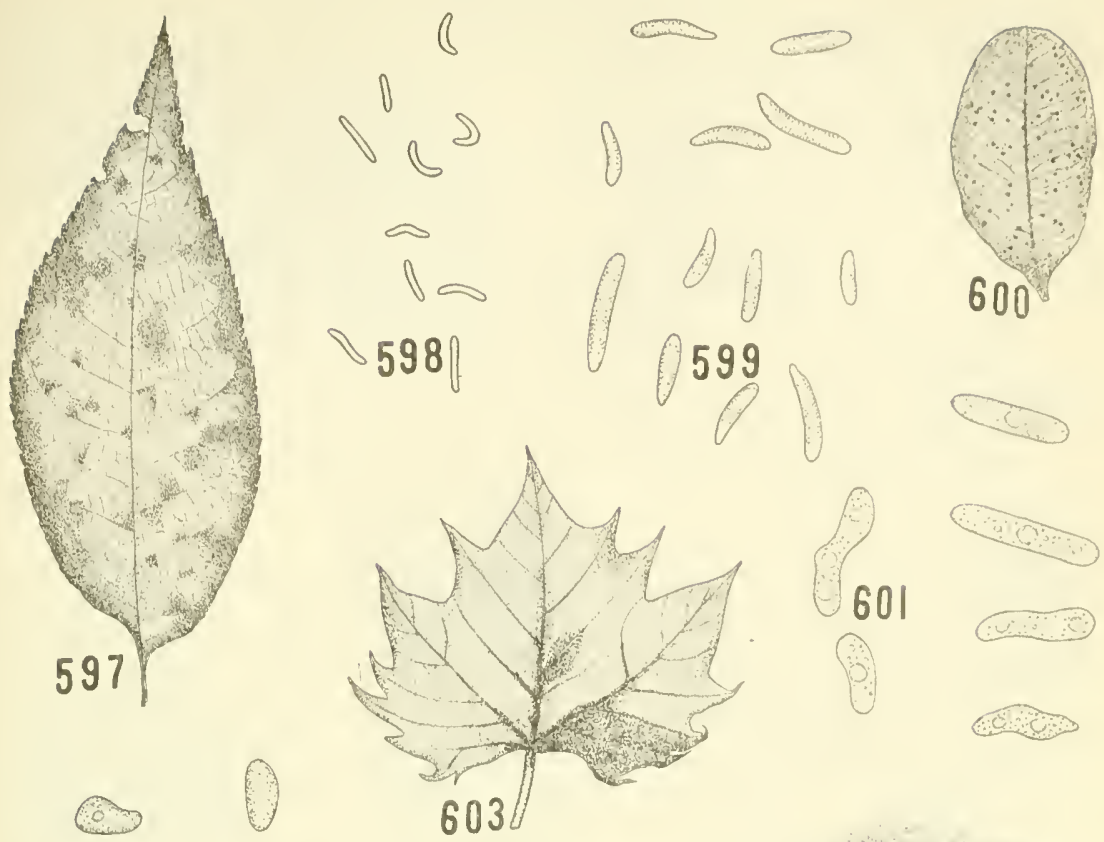

- 800

602

○<smiles>C1=CC=C1</smiles>

605
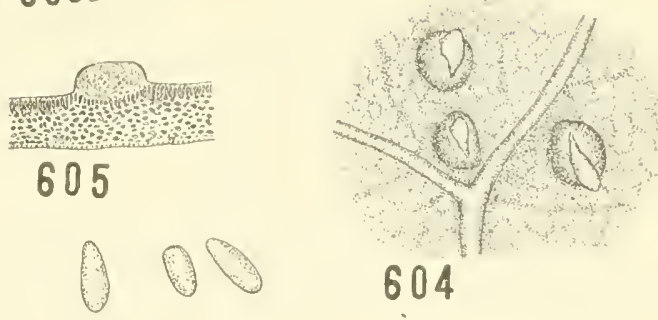

604

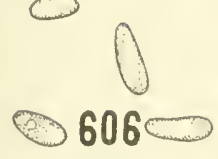

$607 \quad 0609$
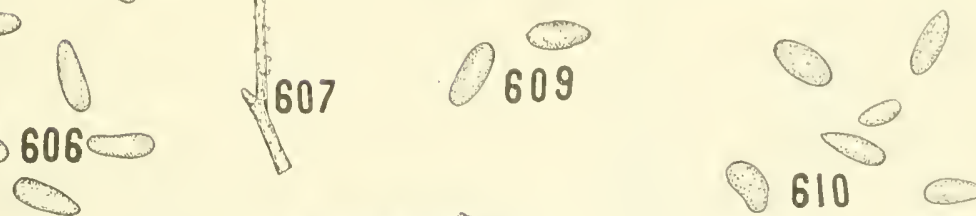

(3)
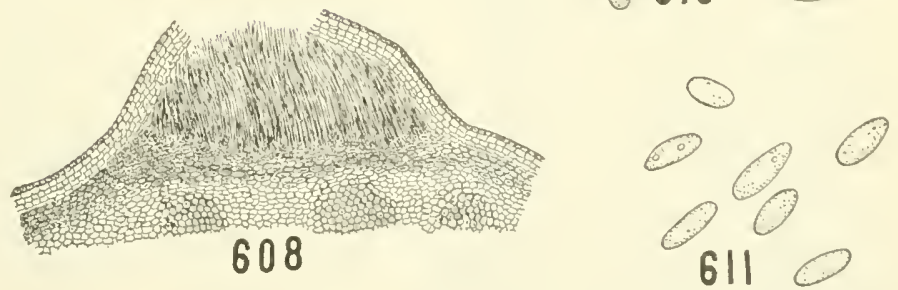
Gleosporium Fusarioides E. \& K. (= Glomerella fusarioides Edgerton, page 58).-On leaves and stems of Asclepias cornuti. Causes numerous small spots. Acervuli numerous and variable. Spore masses on both surfaces of leaf but most abundant above. Spores hyaline, irregular, but mostly oblong and cylindrical, 18-27 x 4.5-6 $\mu$.

600. Infected leaf of Asclepias sp. 601. Spores, 1/12.

Gleosporium musarum Cke. \& Mass.-On the ripe fruit of the tanana. Common on the markets. Causes spotting and rotting of the fruit. Acervuli grouped, erumpent, salmon-colored; conidia elongate-ellipsoid at both ends, non-septate, hyaline, $10-12 \times 4 \mu$.

\section{Spores, $1 / 12$.}

Gleosporium NervisequUm (Fcl.) Sacc. (= Gnomonia veneta (Sacc. \& Speg.) Kelb., page 58).-On the leaves and twigs of the sycamore. Causes a blighting of the leares and young shoots. Acerruli mostly on the upper surface of the leaf, near the nerves, compact, orbicular or nearly so, erumpent, black, 100-200 $\mu$; conidia cozing out in creamy white mass, ellipsoidal, $10-14 \times 4-6 \mu$.

603. Infected leaf of Platanus occidentalus. 604. Acervuli on same, 2/3. 605. Cross-section of same, 2/3. 606. Spores, 1/12. 607. Infected twig from same host showing spores tendrils, 2/3. 608. Cross-section through aceriulus on twig, 2/3. 609. Spores, 1/12. 610. Conidia from leaf, 1/12. 611. Spores from oak leaf, $1 / 12$.

Gleosporium piperatum E. \& E. (= Glomerella piperata (E. \& E.) S. \& S., page 58).-Causes a soft rot, sunken areas on the fruit of the pepper. Acervuli pustular, concentrically grouped; conidia, $12-23 \times 5-6 \mu$.

612. Acervuli, 2/3. 613. Conidiophores and immature contidia. 614. Spores, $1 / 12$

GLEOSPORIUM POLYMORPHUM Tunchili (= Glomerella cincta (B. \& C.) S. \& S., page 58).-On the leaves of Dracaena species in greenhouses. Cause leaf spots, killing the greater part of the tip. Diseased parts brown, becoming ashy-colored, sometimes white, margin chestnut-colored. Acervuli densely grouped, convex, subrotund, covered by epidermis but becoming erumpent, black, 122-208 x 98-149 $\mu$; spore tendrils orange-colored; conidia cylindrical or oblong, ends rounded, straight or very slightly curved, 1 to 3 or more guttulate, granular, hyaline, $14-23.3 \times 4-6.6 \mu$.

615. Infected tip of leaf of Dracaena fragrans showing acervuli. 616. Acerruli and spores tendriis, 2/3. Gil7. Spores, $1 / 12$. 

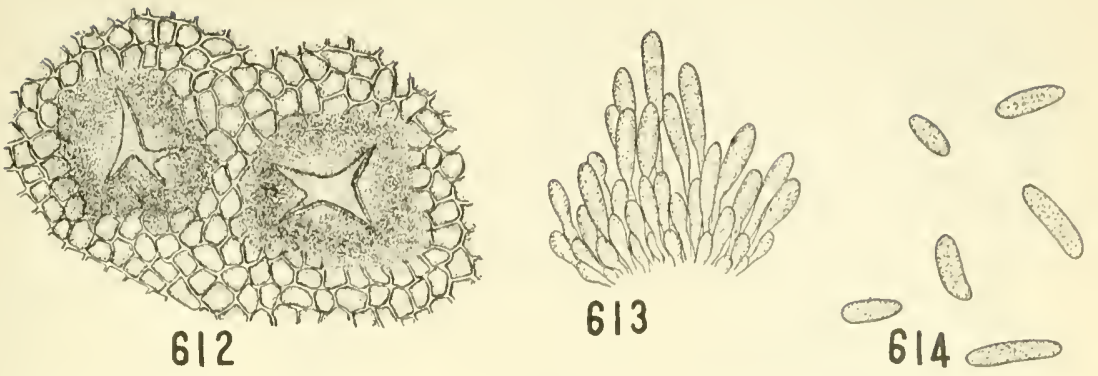

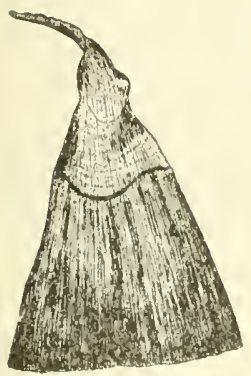

615

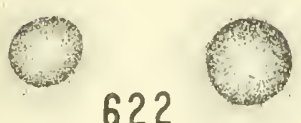

(2)

(2)

625

(o)
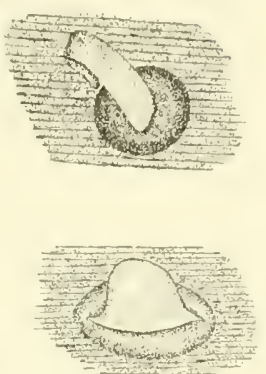

616
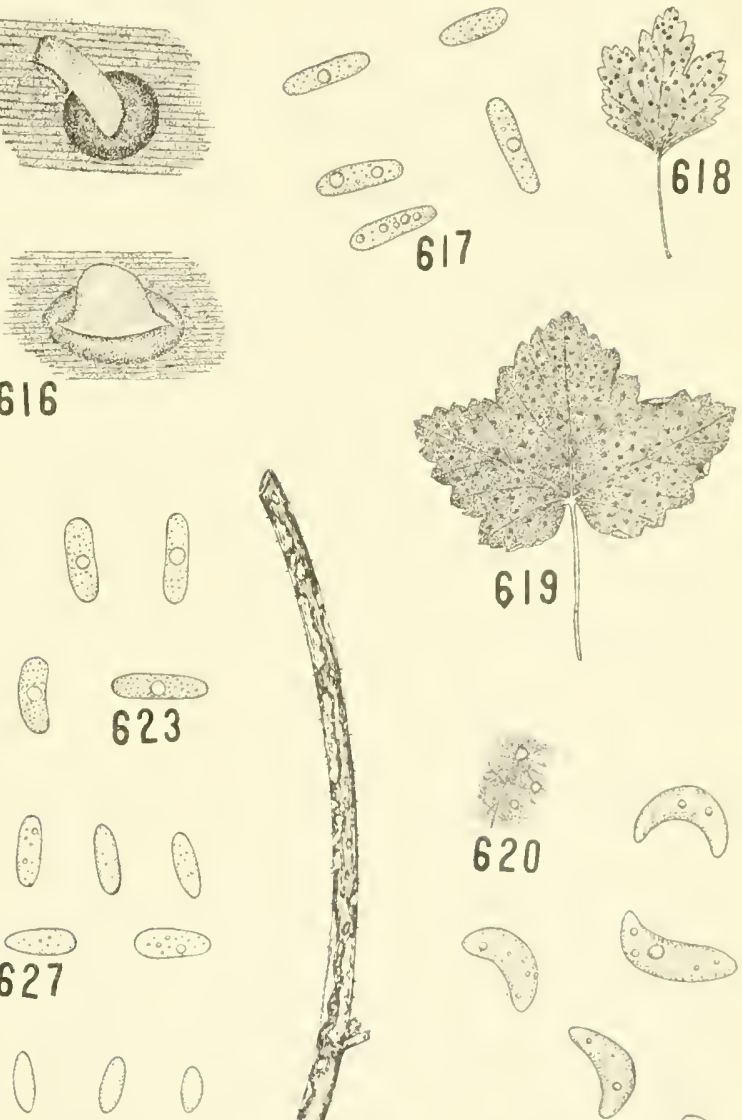

624

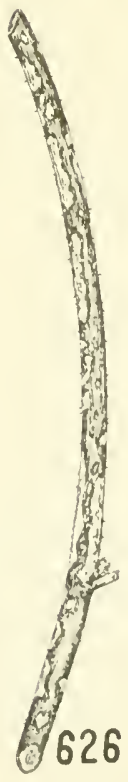

(3) $621 \%$ 
Gleosporium ribis (Lib.) M. \& D. (= Pseudopeziza ribis Kleb., page 22).-On the leaves of the currant and gooseberry, sometimes on petioles, young canes and fruits. Causes small, reddish-brown, sometimes coalescent, spots and finally the yellowing and falling of the leaves. Acervuli abundant on upper surface, and sometimes on lower surface, stromatic, sub-epidermal; conidia pinkish in gelatinous mass, hyaline, elliptical, curved, $12-24 \times 5-9 \mu$.

618. Infected gooseberry lear. 619. Infected currant leaf. 620. Part of same enlarged. 621. Spores, $1 / 12$.

Glagosporium Rufomaculans (Berk.) Thüm (= Glomerella rufomaculans (Berk.) S. \& S., page 50).--On apple and other pomaceous plants. It also attacks grape, tomato, eggplant and other plants. Causes a brown, sunken, rotten area on the fruit from which the acervuli are developed. It also attacks the branches of the apple causing well-defined cankers. The acervuli on the fruit are prominent, arranged more or less in circles, and the emerging spores pinkish or orange-colored in mass, spores hyaline to greenish, unicellular, $28 \times 3.5-7 \mu$. Perithecia more or less grouped on the fruit; asci sub-clavate, 55-70 $\mu$; ascospores allantoid, 12-22 × 3-5 $\mu$.

\section{Acervulus, 2/3. 623. Spores, 1/12.}

Gloeosporium salicis West (= Pseudopeziza salicis, page 22).On the leaves of the willow. Causes small brown or black spots on the upper surface, frequently becoming confluent and causing defoliation. Acervuli abundant on the upper surface, spore tendrils white, spores oblong, non-septate, slightly curved, guttulate, hyaline, 11-15 x 4-6 $\mu$.

\section{Infected willow leaf. 625. Spores, 1/12.}

Gloosporium venetum Speg.-On the canes, petioles and leaves of species of Rubus. Causes morc or less circular or elongated purplish spots, centers becoming gray and sunken, giving the bird's-eye effect, and mostly confluent, $2-3 \mathrm{~mm}$. in diameter; conidia ambercolored in mass, oblong, clliptical, 5-7 × $3 \mu$. (= Plectodiscella vencta Burk. In Phytopatholog., v. 7, p. 83-91, 1917.)

626. Infected dewberry cane. 627. Spores from black-cap raspberry, 1/12. 628. Spores from Welsh raspberry, 1/12.

Colletotrichum antirrhini Stewart.-On the stem and leaves of the cultivated snapdragons. Causes circular, elliptical, often confluent, dark brown spots, $3-10 \times 3-5 \mu$. Acervuli numerous and grouped (especially on the stem); setæe abundant, especially on the stems, dark brown, unbranched, tapering, 50-100 $\mu$ long ; conidia ob- 
Parasitic Fungi of New Jersey

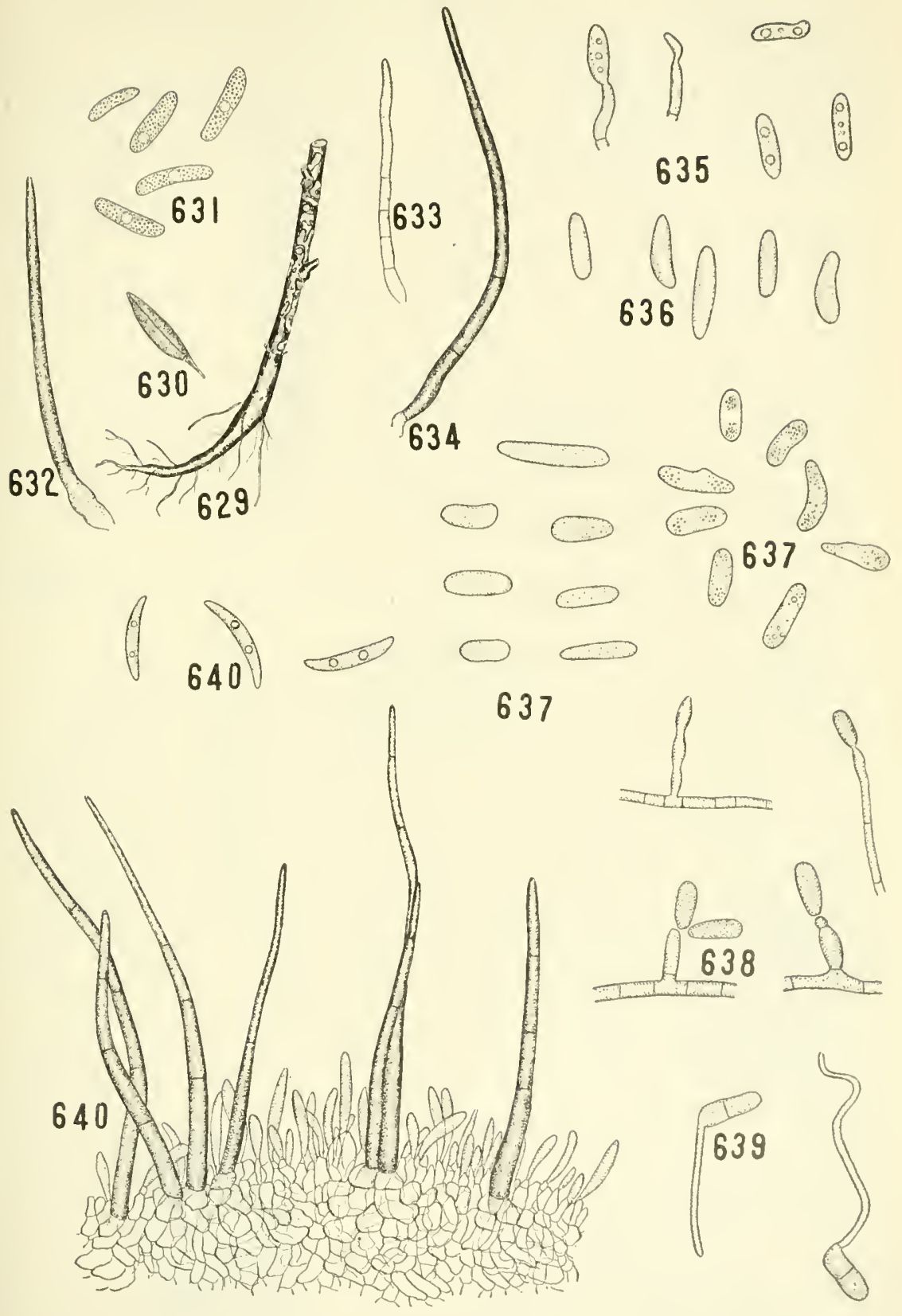


long, rounded at the ends, straight or slightly curved, granular prominent, central vacuole, $16-21 \times 4 \mu$.

629. Infected stem of snapdragon. 630. Infected leaf oí same. 631. Spores, 1/12. 632. Bristle, $1 / 12$.

Colletolrichua cinctuas Ston. (= Glomerella cincta (B. \& C.) S. \& S., page 52).-On leaves of orchids. Causes a spotting and, in serere cases, a dying of the foliage. Acervuli erumpent; conidia elliptical, $12-15 \times 3-4 \mu$; septre present.

633. Immature bristle, 1/12. Є3t. Mature bristle, 1/12. 635. Conidiophore's and coniđia, 1/12. 636. Spores from Catleya sp. 1/12

Colletotrichuil gleosporioides Penz.-On shoots, leaves, flowers and fruit of citrus plants in greenhouses. Causes the "wither tip" on shoots, leaves and flowers and cankers on the fruits. Acervuli scattered, superepidermal, erumpent, dark, setæe, sparingly septate, dark-colored, 40-90 × 5-6 $\mu$; conidia cylindrical with rounded ends, straight or occasionally slightly curved, 16-28 x 4-6 $\mu$.

637. Spores, 1/12, from two sources. 638. Formation of spores on mycelium in culture, 1/12. 639. Germinating spores, 1/12.

Colletotricitum graminicolum (Cesati) Wilson.*-Causes circular or oroid spots on roots, stems, blades and spikes of rye, wheat, cats, barley, emmer, orchard grass, timothy, blue-grass and chess. Causes premature ripening and shrivelling of the grain. Diseased heads have very much the appearance of being attacked by scab (Fusarium culmorum Smith) except that there is no pink overgrowth. Acervuli dark-brown or black; setre few or many, darkbrown or black, $1-2$ septate, $60-120 \mu$ in length and $6-8 \mu$ thick at base; conidiophores very short. $12-6 \times 1-2 \mu$; conidia spindle or boatshaped, 2 to several guttulate, $18-26 \times 3-4 \mu$.

640. Section through acervulus showing bristles and spores, 1/12.

Colletotrichum cyclanenæ Hals. (= Glomerella rufomaculans var. Cyclaminis P. \& C.).-On the leaves of Cyclamen in the greenhouse. Causes prominent spots. Acervuli on both surfaces of the leaves, brown; conidia oblong, linear, obovate, straight or slightly curved, ends rounded, $12-15 \times 4-5 \mu$; conidiophores long. slender, setæ free, short, and rigid.

641. Bristle, 1/12. 642. Spores, 1/12.

* Sin. Colletotrichum cercale Manus.

Colletotrichum sanguineum E. \& $\mathrm{H}$.

Colletotrichum fromi Jennings.

Colletotrichum lineola fachyspora E. \& K. 

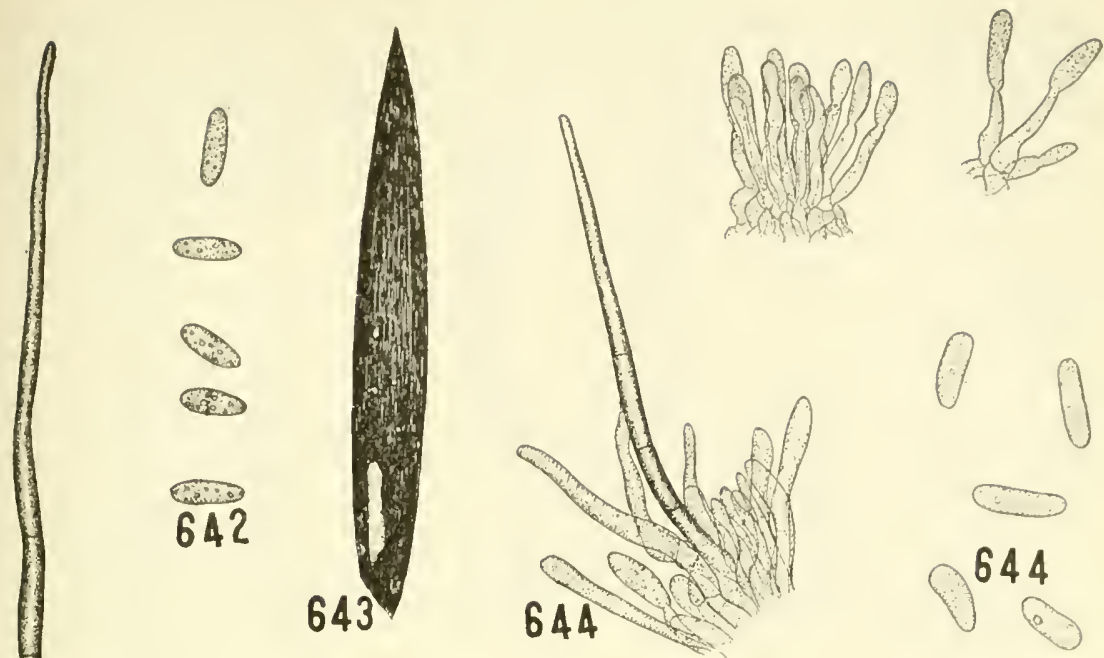

641
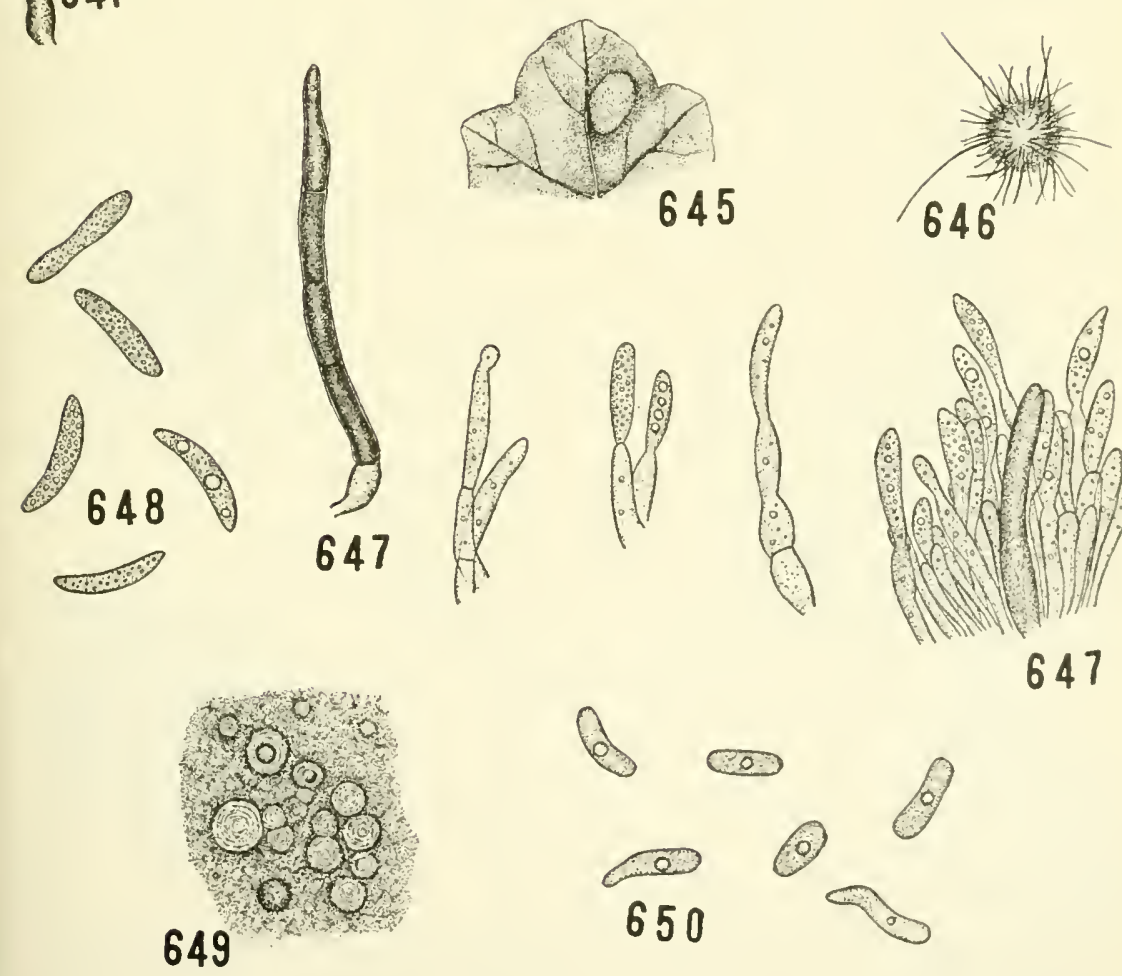
Colletotrichum kentie Hals.-On the leaves of Kentia fosteriana. Causes more or less circular, more or less grayish-brown irregular spots with dark margins. Acervuli numerous on both surfaces of the leaf, epidermis forced up and ruptured by the growing fungus, spores, salmon-colored in mass, cylindrical rounded ends, straight or slightly curved, hyaline, $16.6-20 \times 5-6 \mu$.

643. Infected leaflet of Kentia fostiriana. 64t. Conidiophores, bristles and spores, $1 / 12$.

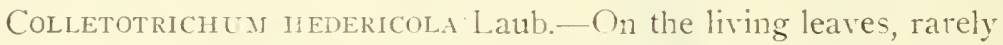
on petioles and branches of Hedera helix. Oral or circular brown spot about $15 \mathrm{~mm}$. in diameter on both surfaces of the leaves. Acervuli on both surfaces, gregarious: setæe straight or curved, septate, $7 \mu$ broad at hase, sometimes as much as $1 \div 0 \mu$ in length: conidia 1-celled, hvaline oblong or subiusiform slightly curved, usually guttulate, $17-26.6 \times 3.3-3.5 \mu$.

645. Portion of leaf of $H$ dera helix showing spot. 646. Acervulus, $2 / 2$ 647. Conidiophores, bristles and spores, 1/12. 648. Matıre spores, 1/12.

Colletotricimer lagevaril ar (Pers.) E. \& H.-Causes spots on the fruit and leaves of watermelons, cucumbers, squash, pumpkins and citrons. Causes brown spots on the leaves and in severe cases an early maturity; causes water-soaked, sunken spots on fruit which develop into rotten areas of various sizes containing numerous acervuli. Spore mass prominent and pink in color. Conidia variable in size and shape, hyaline. There is considerable evidence to indicate that this is really Colletotrichum lindemuthianum.

649. Spots on fruit of watermelon. 650. Spores, 1/12.

Colletotrichum lindeanthianum (Sacc. \& Mg.) B. \& C.-Cn the stems, leaves, pods and seeds of the bean, causing elongated, black spots or streaks on the stems, which become somewhat sunken and pinkish during exudation of spores; causing similar spots on petioles and veins of leaves; causing small, dark-colored more or less circular spots on pods becoming large, sunken and pinkish with spore formation and frequently uniting into unsightly canker-like areas; causing yellowish, brownish or blackish spots on seeds. Acervuli scattered and surrounded by few, rather inconspicuous black setæ, conidiophores cylindric, simple, 45-55 $\mu$. Conidia oblong, ends rounded, 15-19 × 3.5-5.5 $\mu$.

651. Infected root and stem of bean. 652. Infected pods. 653. Cross-section through infected pods. 654. Infected seedlings. 655. Bristles, 1/12. 656. Spores, $1 / 12$. 
Parasitic Fungi of New Jersey
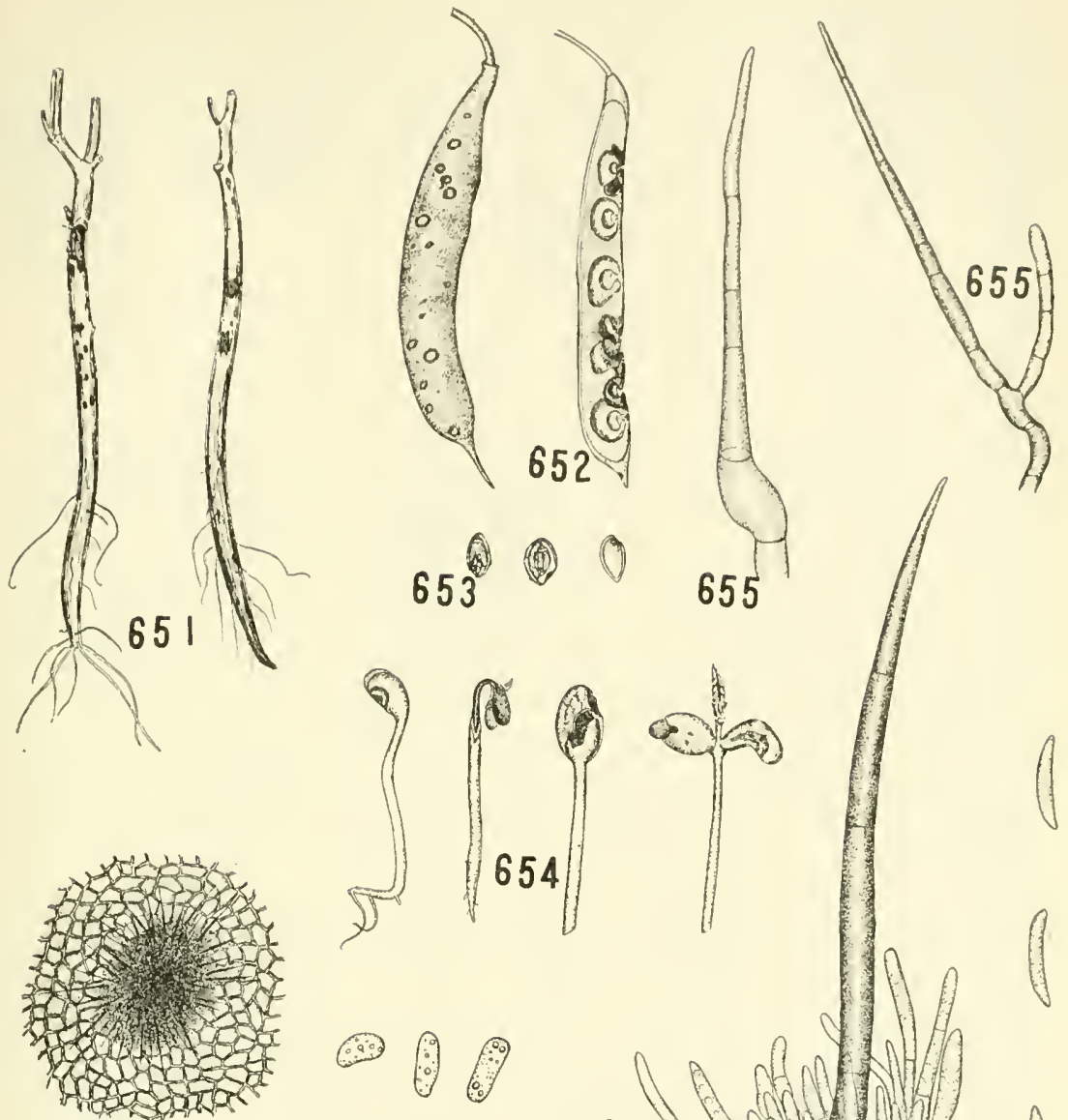

(1) 0

$\int_{5}$

(1)

657
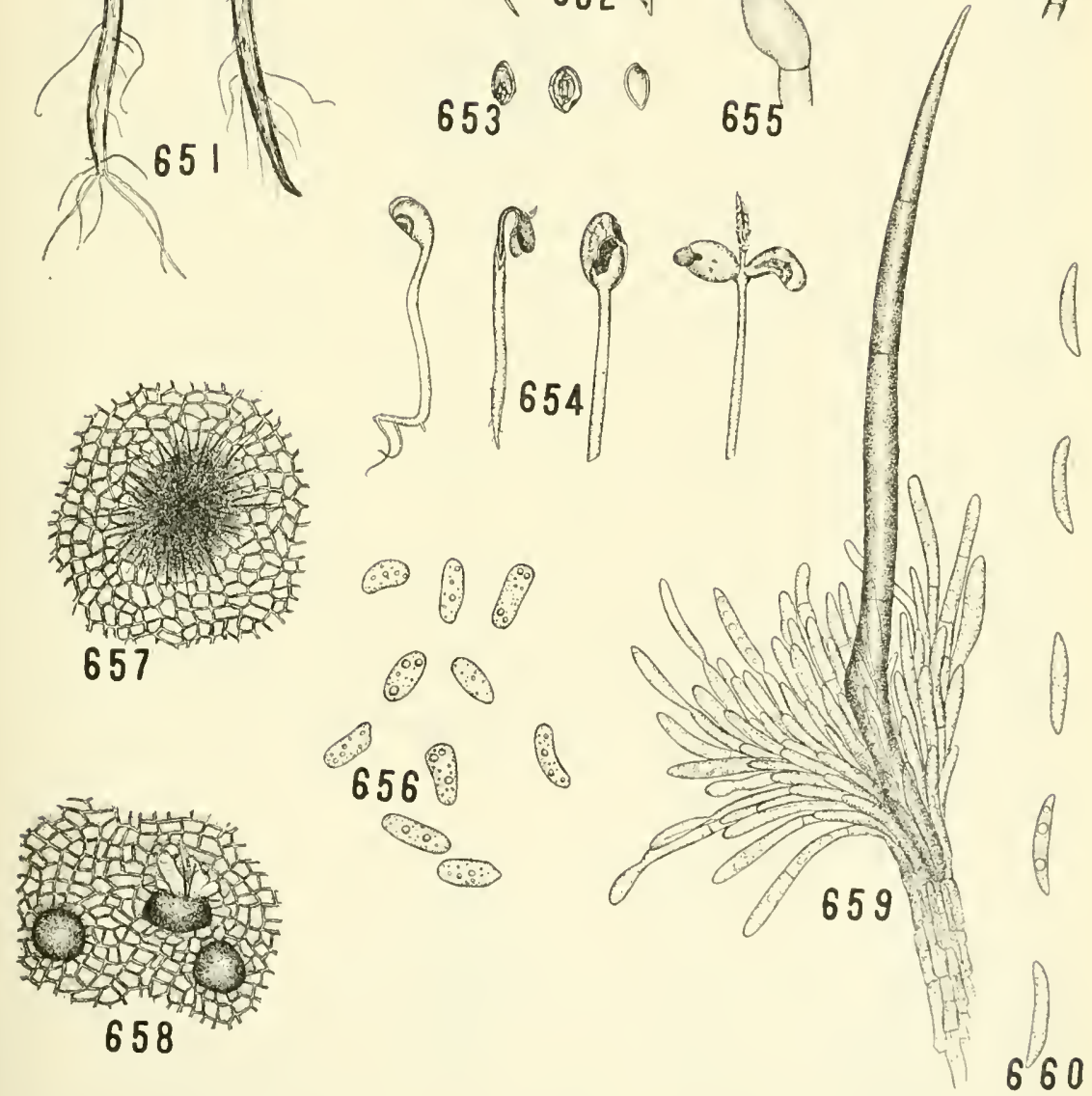
Colletotrichum rigrum. E. \& H.-On the pods of the pepper. Causes black, sunken spots and is followed by decay. The seed are frequently affected with the fungus. Acervuli numerous, superficial and on both outside and inside of the pods; setæ numerous, black, long, pointed, 3- or 4-septate; conidia oblong, somewhat curved, acutely pointed, 18.2-26.6 × 3-3.3 $\mu$.

65\%. Acervulus showing bristles, 2/3. 658. Acervulus showing emerging spores, 2/3. 659. Conidiophores, spores and bristles, 1/12. 660. Spores, 1/12.

Colletotrichum omenorual Hals.-On leaves of Aspidistra and other plants. Causes spots which are dry, irregular gray with vellowish margins, gradually spreading and frequently destroying the entire leaf. Setæ numerous (Halsted says "few"), black, prominent, lointed; conidia hyaline, usually slightly curved, 20-28 x 3-5 $\mu$.

661. Spot on leaf of Aspidistra sp. 662. Bristles, 2/3. oú3. Spores, 1/12.

Colletotrichum PHomoides (Sacc.) Ches.-On the firuit of the tomato. Causes circular, depressed, water-soaked spots which vary in size and become blackish, unite and finally rot the entire fruit. Acervuli abundant, grouped, brown or black, 95 to $150 \mu$; setæ numerous, dark, usually curved, septate, 65-112 $\mu$; conidiophores short, - iender, 30-40 $\mu$ in length; conidia oblong with rounded ends, 16-24 $\times 4 \mu$.

664. Infected fruit of tomato. 665 Acervulus showing bristles, 2/3. 666 . Bristles, 1/12. 667 and 668. Sipores from different sources, 1/12.

Colletotrichum RUBicolum E. \& E. (= Glomerella rubicola (Ston.) E. \& E., page 52).

COlletotrichum trifoli Bain.-On the stems and occasionally on the leaves of clover and alfalfa. Causes more or less elongated, lark, sunken spots. Acervuli scattered or grouped; erumpent; setæ few or many, usually septate, dark, with light-colored tips; conidiophores cylindric or fusoid and hyaline; conidia pinkish in mass, more or less oblong, 3-4 × 11-13 $\mu$.

669. Spots on infected stem of Trifolium sp. 670. Bristles, 1/12. 671. Spores, $1 / 12$.

Colletotrichuir viol i-Tricoloris R. E. Smith.-On the leaves and blossoms of the pansy. Causes small, yellowish, often confluent spots with distinct black margins. Acervuli numerous $50-150 \mu$ in diameter; setæ solitary or in twos, brownish, 1-3 septate, 20-70 $\mu$ long, tapering to a blunt tip; conidia oblong, rounded at the end, sometimes slightly curved, granular, guttulate, $20 \times 5 \mu$.

672. Infected pansy leaf. 673. Bristle, 1/12. 674. Spores, 1/12. 

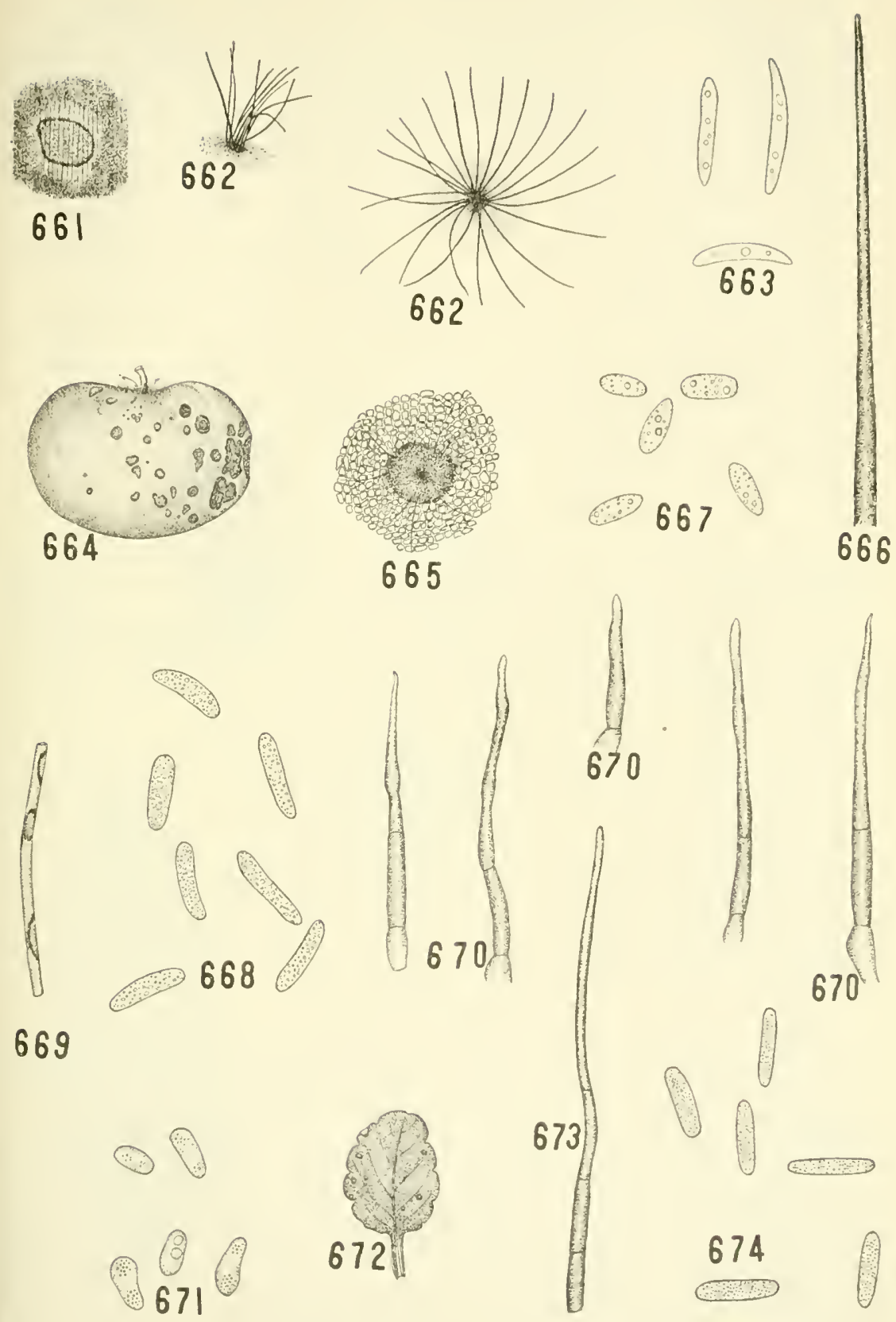
Melanconiun fuligineum ( $\mathrm{S}$. \& $\mathrm{V}$.) Cav.-On the ripening fruit of the grape. We have also found it very abundant on the very small green berries, and pedicles in June. Causes a bitter rot of ripe berries and dying of young berries and pedicles. Acervuli scattered or grouped, grayish-cinereous, becoming brownish, subepidermal, erumpent; conidiophores filiform, conidia ovoid to ellipsoid or very much elongated, rounded or pointed, olive-colored, 9-12 × 4-6 $\mu$.

675. Cross-section of acervulus from fruit of grape, 2/3. 676. Conidiophorts and conidia from different sources, 1/12. 677. Germinating conidia, 1/12.

Marssonia brunnea $\dagger$ (E. \& E.) Sacc.-On the leaves of Populus candicans. Causes numerous, small black spots which become confluent. especially around the margins. Accrvuli on both surfaces of the leaf, 1-3 in each spot, pale, becoming black, erumpent; conidia clavate, hyaline, 1-septate; the two cells of unequal size, 14-16 $\mathrm{x}$ $5-7 \mu$.

678. Spores, $1 / 12$.

Marssonia Juglandis (Lib.) Sacc. (= Gnomonia leptostyla C. $\&$ d. Not., page 58).-On the leaves of the walnut. Causes black spots of irregular shape and size. Acervuli grouped on under surface of the leaf; conidia ovoid, pointed at one end, truncate at the other, slightly greenish in color, 1-septate, $8-10 \times 4-5 \mu$.

679. Infected leaflets of walnut. 680. Cross-section of acervulus, 2/3. 681. Conidiophores and conidia, 1/12. 682. Conidia, 1/12.

Marssonia Martini Sacc. \& Eill.-On the leaves of Quercus alba. Causes small, ochre-colored spots on both surfaces of the leaf. Acervuli in the under surface, globose, somewhat amber-colored; conidia fusiform, slightly curved, acute at both ends, 1-septate, slightly constricted, hyaline, $12-15 \times 2.5-4 \mu$.

683. Spores, $1 / 12$.

Marssonia ochroleuca* B. \& C.-On the leaves of the chestnut. Causes small pale brown or ashy-colored, circular, or oval, occasionally confluent spots surrounded by narrow dark margins, 2-3 mm. in diameter. Acervuli on under surface, few (1 to 5), palc, in center of spots; spores hyaline, crescent-shaped ends slightly pointed, 1septate, $20-25 \times 2.5-3 \mu$, oozing out in an amber-colored mass.

684. Infected leaf of chestnut (Castanea dentata). 485 . Spores from leaf of $C$. dentata, 1/12. 686. Spores from leaf of C. vesca, 1/12.

†This genus has been recently changed to Marssonina.

* Syn. Septoria ochroleucr. 
Parasitic Fungi of New Jersey

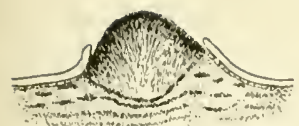

675

0000 ○676
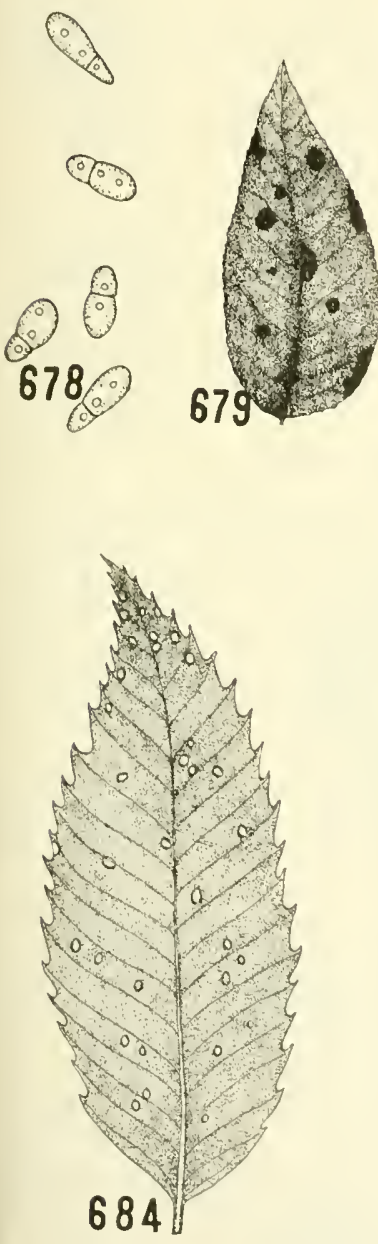

O

676

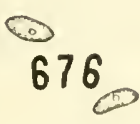

- 0
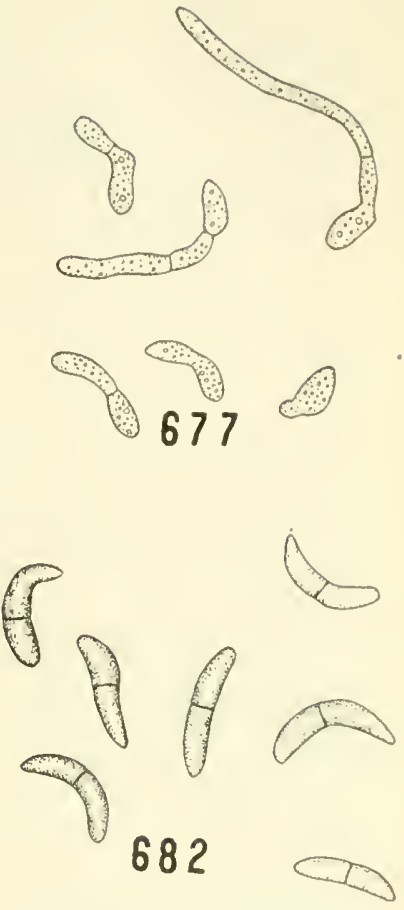

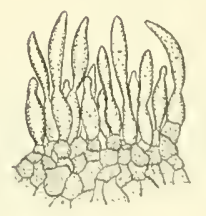

681
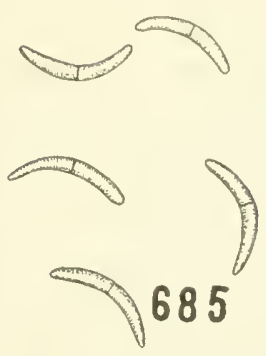

नि

683

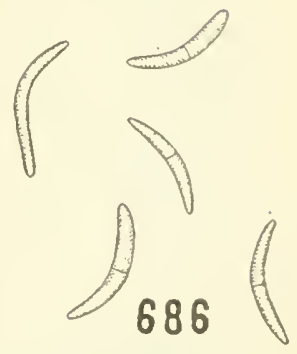


Marssonia populi (Lib.) Sacc.-On the leaves of the Populus. Causes a spotting and a blighting of the leaves and lateral shoots. Spots suborbicular with dark margins and frequently uniting, acervuli on the upper surface, yellow or flattened; conidiophores tranched and septate; conidia hyaline, unequally 2-celled, constricted at the septum, $14.9-20.0 \times 5.5-7.7 \mu$. (Saccardo says " $20 \times 12$. .)

687. Infected leaf of Populus alba. 688. Acervulus showing conidiophores and spores, 1/12. 689. Conidia from Populus deltoides, 1/12. 690. Conidiophores and conidia from $P$. alba.

Marssonia potentille (Desm.) Fisch., var. fragaria Sacc. On the leaves of the strawberry. Causes small, ochre-colored or reddish spots with indefinite outline or reddish margins. Acervuli dark, conidia irregular, 1 -septate, cells unequal in size, $18 \times 5-6 \mu$.

691. Infected strawberry leaflet. 692. Conidia, 1/12.

Marssonia rhabdospora E. \& E. On the leares of Populus grandidentata. Causes spots visible on both surfaces. Acervuli on the under surface of the leaf, flesh-colored, erumpent; conidia cylindrical, slightly curved, 1-septate, hyaline, $20-30 \times 2 \mu$.

693. Spores from Populus grandidentata, 1/12.

Monochaetia Mali (E. \& E.) Sacc.-On the leaves of the apple. Causes small, circular white or cream-colored spots with reddishbrown margins and about 1-3 mm. in diameter. Acervuli innate, erumpent, sublenticular; conidia cylindrical, 5 or 6 septate, sometimes constricted, $20-25 \times 6-7 \mu$, brown, apical, and basal cells, conical and hyaline.

694. Infected apple leaf. 695. Acervulus, 2/3. 696. Conidiophores from hanging-drop culture, 1/6. 697. Spores, 1/6. 698. Spores, 1/12. 699. Germinating spores, $1 / 6$.

Pestalozzia guepini Desm.-On sunburnt leaves of Rhododendron. Acervuli minute, convex, dark; conidia fusiform, 3-4 septate, $20 \mu$ long, inner cells brown to olive-colored, terminal cells coneshaped and hyaline, basal cell hyaline and with 3 or 4 appendages.

700. Conidia, 1/12.

Pestalozzia guepini var. vaccinii Shear. - On the leaves and sometimes on the fruit of the cranberry. Causes a rotting of the fruit which is not easily distinguished from rots due to other organisms. Acervuli scattered, subepidermal, spores emerging in dark 


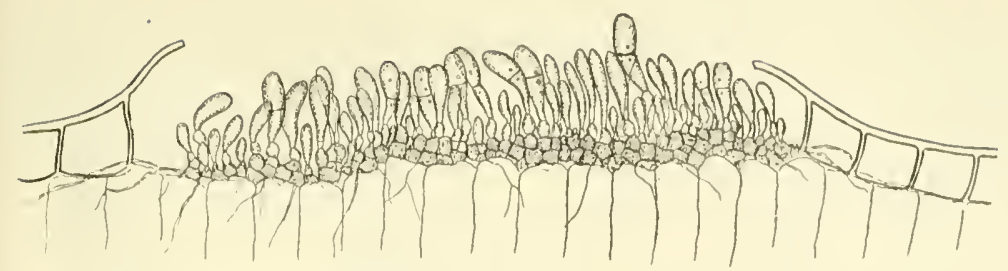

688

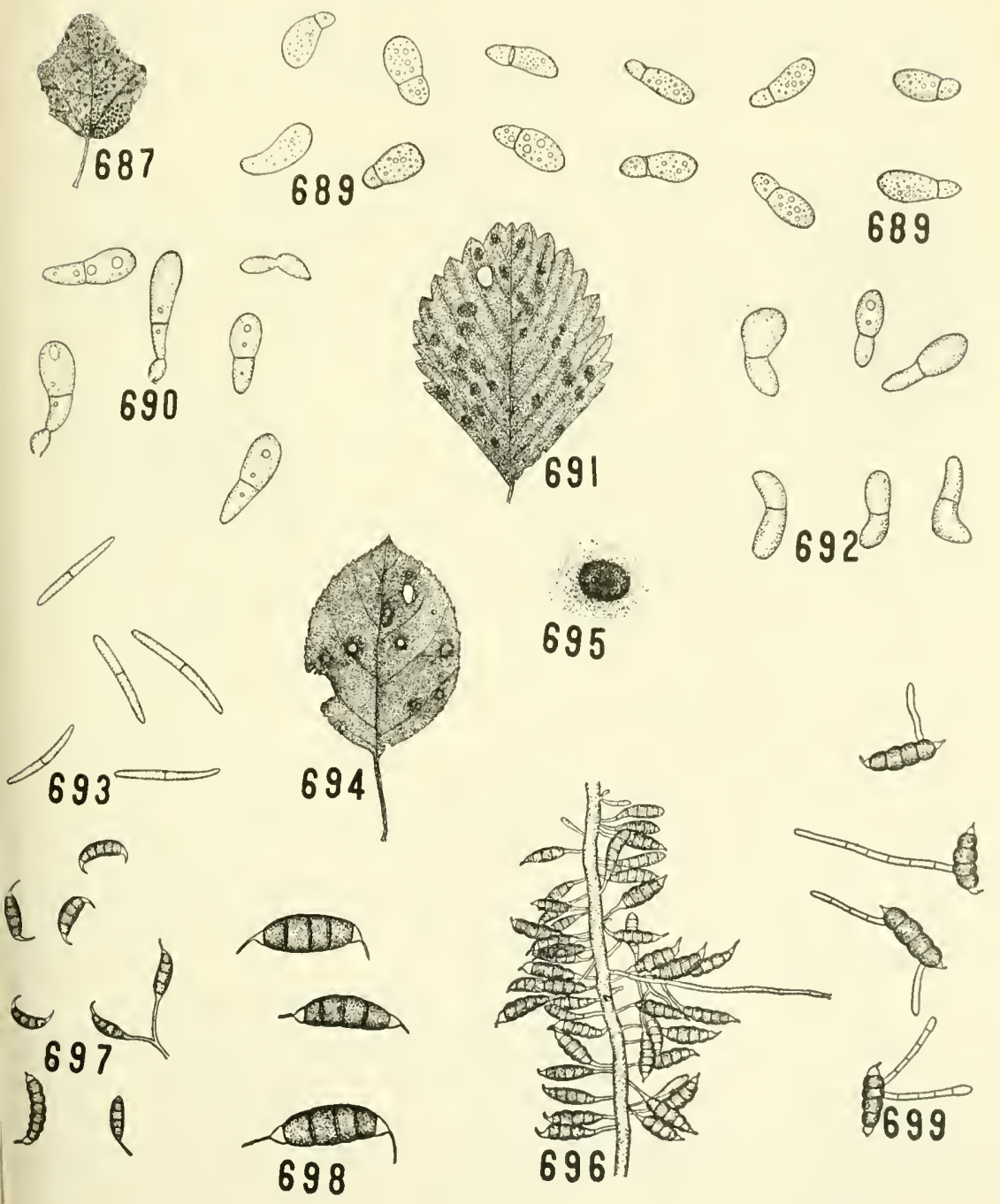


masses and spreading over the surface, elliptical, somewhat inequilateral, usually 4-septate, the three central cells dark-colored, usually guttulate, terminal cells hyaline; apical cell with 3 or 4 filiform setæ, varying from 22 to $35 \mu$ in length; basal cell with a short hyaline appendage $6-12 \mu$ in length.

701. Conidia, 1/12

Pestalozzia ros 至 West.- On the dying twigs of cultivated roses. Apparently a secondary parasite. Acervuli minute, white, dense; conidia fusiform, smoky to olive-colored, 4-septate, 20-26.6 × 5-6.6 $\mu$, terminal cell cone-shaped and hyaline, basal cell hyaline and with 2 appendages.

\section{Conidia, $1 / 12$}

Cylindrosporilar padi. Karst.-On the leaves of the wild and cultivated cherry and occasionally on the fruit of the wild cherry. Causes reddish-brown circular, angular, or irregular spots visible on both surfaces, frequently falling away and giving the "shot hole" effect; pycnidia subepidermal; spores yellowish-tinged, curved, 1septate, $48-6() \times 2 \mu$.

Note: Higgins [Amer. Jour. Bot. v., 1, p. 145-173 (1914)] says that it is not known that $C$. padi occurs in America. He describes three American species of this genus, with perfect stages belonging to Coccomyces. Since the Cylindrosporinm stages of these three species are so nearly alike we prefer to use the $C$. padi until exact determinations can be made.

703. Infected cherry leaf. 704. Cross-section of acervulus. 2/3. 705. Conidia from two sources, $1 / 12$.

Cylindrosporium toXicodendri* (Curtis) Dearness - On the living leaves of Rhus toxicodendron and other species of Rhus. Causes irregular dark brown spots, with irregular darker borders, visible on both surfaces. Acervuli scattered, convex, black; conidia cylindrical, straight or curved, non-septate or 1-3 septate, hyaline, $21-78 \times 3-5 \mu$.

706. Infected leaf of Rhus radicans. 707. Conidia 1/12.

Monilia fructigena. Pers. (= Sclerotinia fructigena (Pers.) Schr., page 22).

*Syn. Septoria toxicodendri Curtis.

Glocosporium toxicodendri E. \& M.

Septoria toxicodendri (Curtis) E. \& M.

Marssonina toxicodendri Magn. 

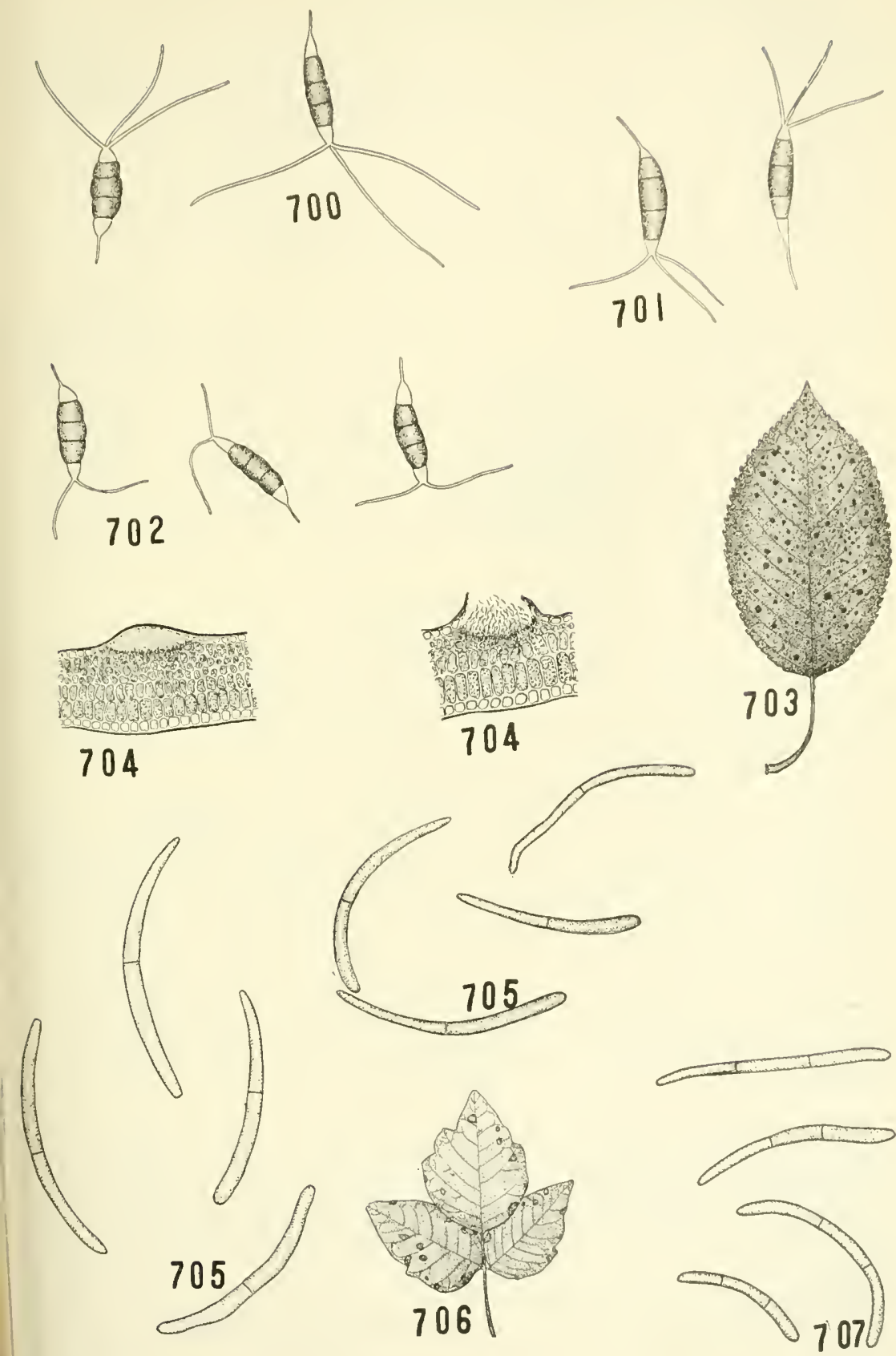
OIDIUM FRAGari玉 Hatz. (= Spharotheca humuli (D. E.) Rurt, page 32).

Ordiux Leucoconium Desm. (= Spharotheca pannosa (Wallr.) Lev., page 32).

Oidicar amibrosia Thüm. (= Erysiphe cichoracearum D. C., page 26).

Oidiux yoxilioides Link (= Erysiphe graminis D. C., page 26). Ordium tUckeri Berk. (=Uncimula necator (Schw.) Burr., page 32).

Oidiun CRategi Grogn. (= Podosphara oxyacanthae (D. C.) DeBary, page 30 ).

SPorotricilum POE Peck.-On carnations. Causes a rotting of the buds. Hyphe hyaline. creeping cottony, branched, septate, 2.5-6 $\mu$ in diameter ; micro-conidia elongate-elliptic to ovate-elliptic, ussually, 1-septate, occasionally more, 3 or 4 times as large as the micro-conidia. This organism is carried from plant to plant by a mite (Pediculoidus dianthophilus).

\section{Mrycelium and spores, $1 / 12$.}

Botrytis parasitica Car.-On tulip buds. Causes a rot. Hyphæ ashy-colored, sparse, erect, branching, inflated at base ; conidia large, usually ovate, but more or less irregular, pedicillate, heads umbellate, hyaline to slightly ashy, $16-20 \times 12-13 \mu$.

709. Conidıonlores and conidia from tulip, 2/3. 710. Conidia, 1/12.

Botrytis vilgaris* Fr.- On cultivated Primula. Causes a dring of the leaves. Hyphr, slender, septate, branched, erect, ashy or olive-gray; conirlia globose, smooth, hyaline or pale, $10-1 \times 7-9 \mu$.

711. Infected leaf of Primilg sp. 712. Conidiophores and conidia from same, 2/3. 713. Conidia, 1/12. 714. Conidiophores and conidia from rose, 2/3. 715. Swollen tip of branchlet of conidiophore showing collidia attached, $1 / 6$. 716. Conidia from lettuce, 1/12. 717. Conidiophores from lettuce, 2/3. 719 . Spores, 1/12.

Cephalothecium roseu ir Cda.-On scab spots on fruit of the apple and also on many other hosts. Causes the so-called "pink rot." Spots whitish or pinkish; conidiophores erect, unbranched, non-septate, hyaline: conidia oblong-ovate, 2-celled and constructed at the septum.

719. Conidiophores and conidia, 1/6. 720. Conidiophores and conidia, 1/12.

* Syrr. $R$. cincrea Pers 
Septocylindrium aromaticum Sacc.-On the leaves of Acorus calamus. Causes oblong, somewhat irregular, brown spots on both surfaces of the leaf. Conidiophores fasciculate, short, white, conidia cylindrical, rounded at the ends, denticulate at one end, hyaline, non-septate or 1 to 3-septate, not constricted, 35-50 × 2-3 $\mu$.

721. Infected tip of leaf of Acorus calamus. 722. Conidiophores and coni. dia, $1 / 12$.

Septocylindrium concomitans (E11. \& Hals.) Hals.-On the leaves of Bidens frondosa. Causes oval or irregular, pale brown spots with purplish border which is more prominent on upper than lower surface, 2-4 mm. in diameter. Conidiophores fasciculate, short: conidia cylindrical with acute ends, non-septate or 1-2 septate, $15-22 \times 3-4 \mu$.

723. Infected leaf of Bidens frondosa. 724. Conidiophores and conidia, 1/12.

RAMUlaria ARMORACE F Fi. - On the leaves of horse-radish. Causes subochraceous spots which become gray with age. Conidiophores fasciculate, continuous, sub-simple, $40-50 \times 2.5-3 \mu$; conidia rorl-shaped, obtuse, hyaline, $15-20 \times 3-4 \mu$.

\section{Conidiophores and spores, 1/12.}

Ramularia arvensis Sacc.-On the leaves of Potentilla monspeliensis. Causes small, subcircular, white spots with reddish margins. Conidiophores fasciculate, denticulate, 1-septate, hyaline ; conidia more or less cylindrical, sometimes wavy in outline, one end sometimes swollen or knobbed, non-septate or 1-septate, 22-26 $\mathrm{x}$ $2-5.4 \mu$.

726. Infected leaf of Potentilla monspeliensis. 727. Conidiophores and conidia, $1 / 12$.

Ramularia Desmodir Cke.-On the leaves of Meibomia. Causes pale yellow spots. Conidiophores primarily in irregular patches, limited by the veinlets, non-septate or 1-2 septate, hyaline, $50-80 \times 3-4 \mu$; conidia oblong or clavate-oblong, straight or slightly curved, 1-, rarely 2- or 3- septate, hyaline, $12-24 \times 3.5-4 \mu$.

728. Conidiophores and conidia, 1/12.

Ramularia plantaginis E. \& M.-On the leaves of Plantago lanceolata. Causes small, circular or irregular, grayish, frequently white spots, with reddish or purple margins. Conidiophores fasciculate, somewhat wavy, sometimes branched, non-septate, hyaline, $35-40 \times 3-3.5 \mu$, conidia cylindrical, non-septate or 1-2 septate, 15-38 $x+\mu$. 
Parasitic Fungi of New Jersey
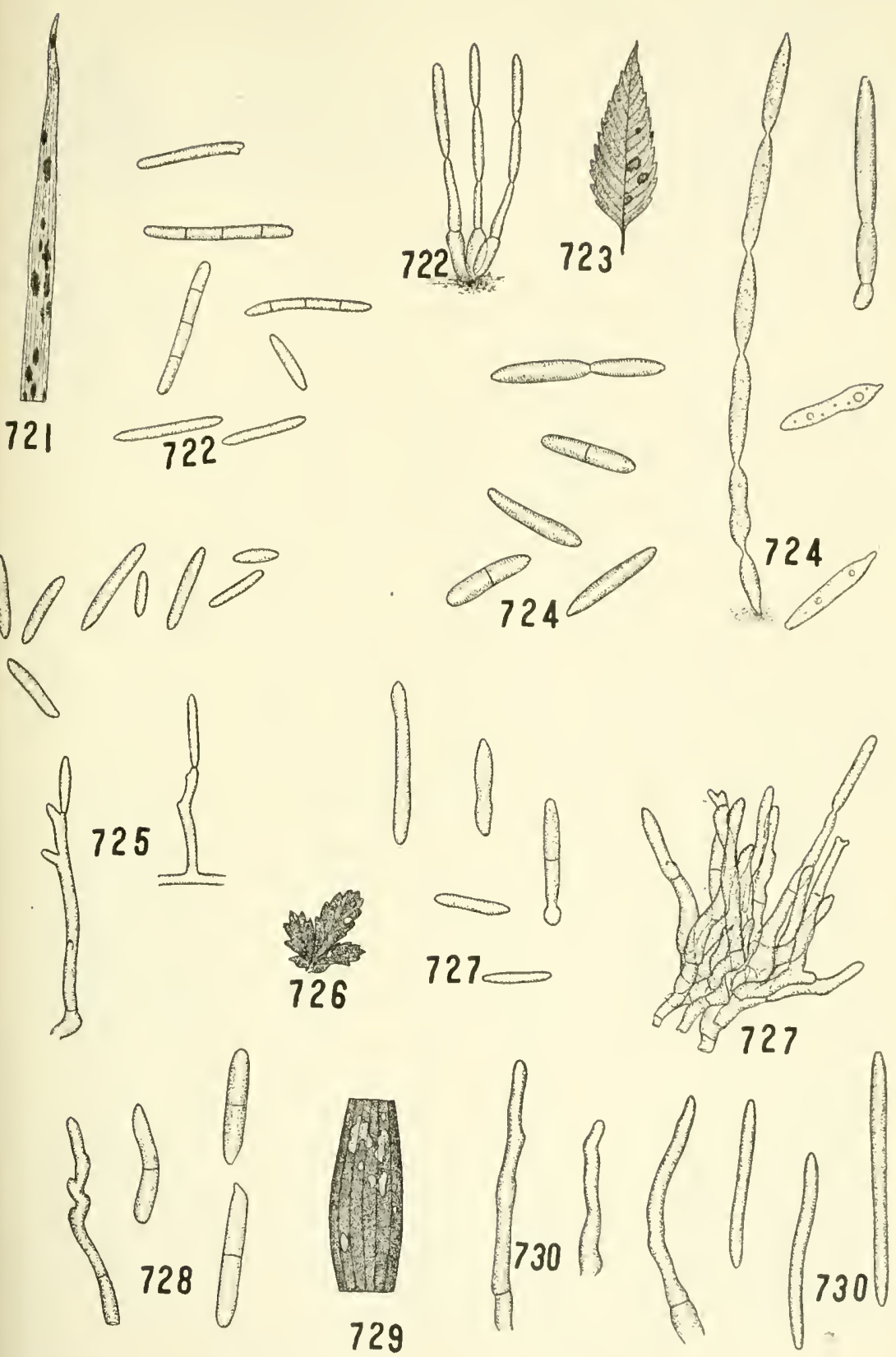
729. Part of infected leaf of Plantago lanceolata. 730. Conidiophores and conidia, $1 / 12$.

RAMULARIA TARAXACI Karst.-On the leaves of Taraxacum taraxacum. Causes grayish-brown circular spots with purple margins on both surfaces of the leaves and shows concentric circles. Conidiophores borne in tufts on the under surface of the leaf, branched, non-septate, hyaline, 35-45 × 2-3 $\mu$; conidia cylindrical, usually 1 -celled, occasionally 1-septate, hyaline, $18-30 \times 2-3 \mu$.

731. Part of infected leaf of Taraxacum taraxacum. 732. Conidia, 1/12.

RAMULARIA TUlasNeI Sacc. (= Mycospharella fragarie (Tul.) Lin., page 44). - On leaves of strawberry. Causes white or gray, more or less circular spots with broad dark-red margins. Conidiophores cylindrical. non-septate, hyaline, $30 \times 3-4 \mu$; conidia cylindrical, non-septate or 1-2 septate, hyaline, $20-35 \times 3.5-4.5 \mu$.

733. Infected strawherry leaflet. 734. Conidia, 1/12.

Piricularia grisea (Cke.) Sacc.-On leaves and stems of grasses. Causes grayish or ashy-colored spots. Conidiophores rise from stomata in clusters of 2 or 5 , grayish in color, septate, siniple, occasionally sparingly branched; conidia single, terminal in scorDioid cymes, ovate, 2-septate, 24-29 × 10-12 $\mu$.

Very similar to $P$. oryzae Br. \& Cav. which causes the rice blast.

735. Infected leaf of grass. 736. Conidiophores and conidia, 1/12.

MINILOCH ATES INFUsCans E. \& H.-On the fleshy roots of the sweet potato. Causes peculiar dark discolorations. Conidiophores attached to host singly or by twos by a bulb-like enlargement, erect, unbranched; septate, dark, 40-175 x 4-6 $\mu$; conidiospores unicellular oblong, hyaline, $12-20 \times 4-7 \mu$.

737. Infected root of sweet potato. 738. Conidiophores showing swollen cells and conidia, $1 / 12$.

Cercosporelda CANa (Pass.) Sacc.-On leaves of Erigeron canadensis. Causes whitish spots. Conidiophores on the under side of the leaf, cylindrical, occasionally septate, short, obtusely branched. Conidia cylindric obclavate, 3-4 septate when mature, minutely guttulate, slightly curved, hỹaline, $60-90 \times 4-5 \mu$.

739. Conidiophores, 1/12. 740. Conidia, j/12. 
Parasitic Fungi of New Jersey

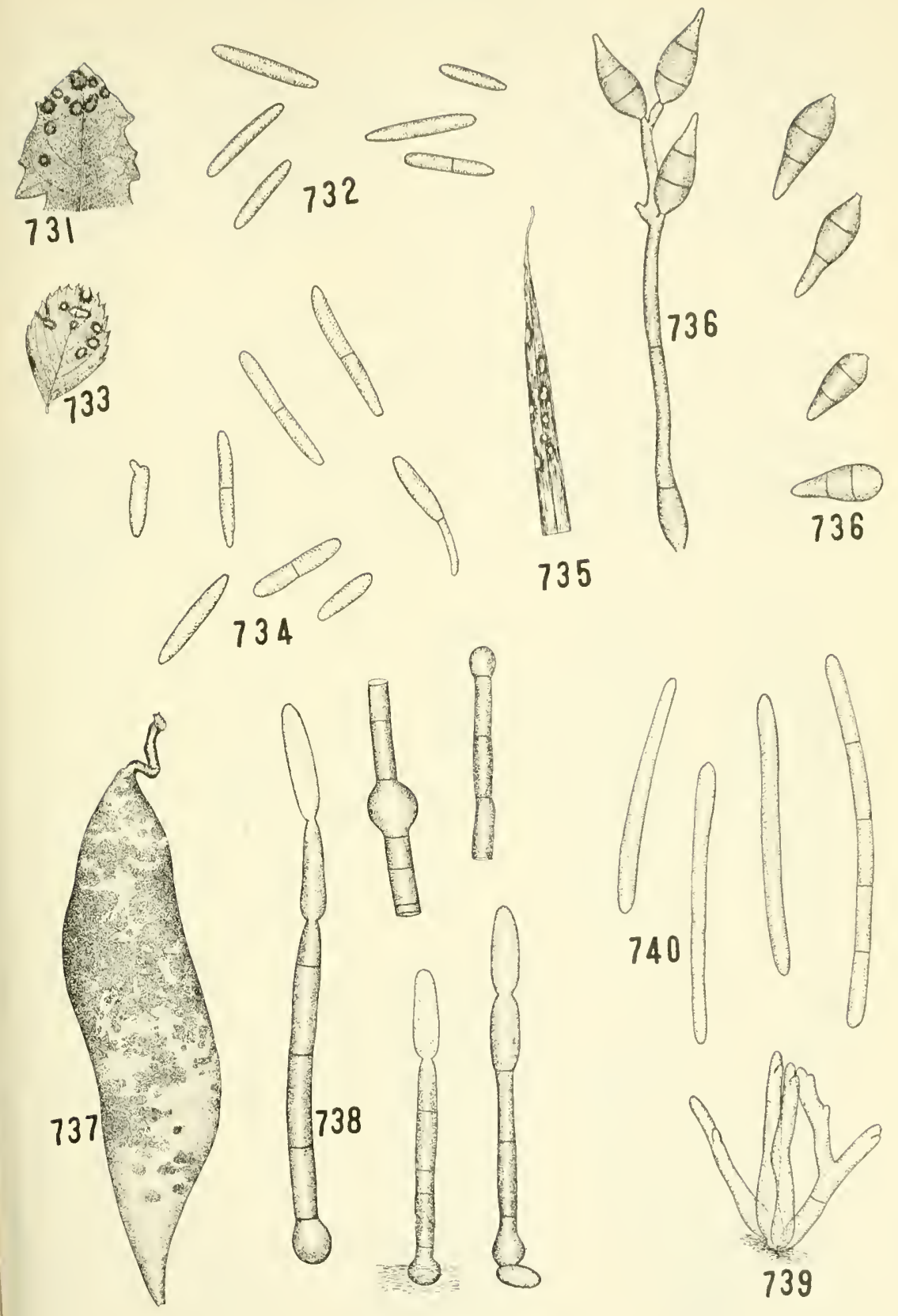


CladosPoriun CARPOPHILUM Thüm.-On fruit, foliage and twigs of peaches, plums, nectarines and cherry. Causes the scab or freckles. Fungus grows on surface of fruit, causing small, circular, blackish, occasionally confluent spots on the surface of the fruit. It also attacks the twigs, causing a cracking of the cuticle and also causes "shot holes" in the foliage. The conidiophores are erect, simple, sinuous, septate ; conidia, ovate, obtuse, continuous or 1-septate, $10-12 \times 4-6 \mu$.

741. Infected peach. 742. Conidiophores and conidia, 1/12.

Cladosporium fulvun Che.-On the leaves and fruit of the tomato, in the greenhouse and sometimes in the field. Causes a dense white or grayish to brownish mold on the under surface of the leaves, and in severe cases on the upper surface, and a rotting of the fruit. Upper surface of the leaf yellow. Conidiophores rupturing the cuticle, dense, sparingly branched, septate nodulose; conidia few, elliptic to oblong, 1-4 septate, translucent, tawny, 10-20 x $4 \mu$.

743. Infected tomato leaf. 744. Conidiophores, 1/12. 745. Conidia, 1/12.

Cladosporium herbarua (Pers.) Lk. (= Mycospherella tulasnei Jarz.).- On the maturing heads of wheat. Causes a dense, velvety black growth over the glumes; conidiophores erect, septate, rarely branched, often nodose or keeled; conidia often in chains of 2 or 3 , more or less cylindrical with rounded ends, pale olive-green, $1-3$ septate, $10-15 \times 4.7 \mu$.

746. Infected head of wheat. 747. Conidiophores, 1/12. 748. Spores, 1/12.

Helintathosporium inconspicuun C. \& E.-On corn leaves. Causes peculiar large, elongated, brownish blotches, frequently surcounded by a broad reddish-border. Hyphæe elongated, septate, nodulose, pale brown; conidia lanceolate, thick-walled, 3-5 septate, $80-120 \times 20 \mu$. An Altemaria sp. is frequently present on the larger and older spots.

749. Part of infected leaf of corn. 750. Conidiophores, 1/12. 751. Conidia, $1 / 12$

Politiriciun trifolit Ktze. (= Phyllachora trifolii (Pers.) Fcl., page 42).

Fusicladiun dendriticuar (Wal.) Fcl. (= Venturia incqualis, page 48).

Fusicladium pirinum (Lib.) Fcl. (= Venturia pirina, page 48). 


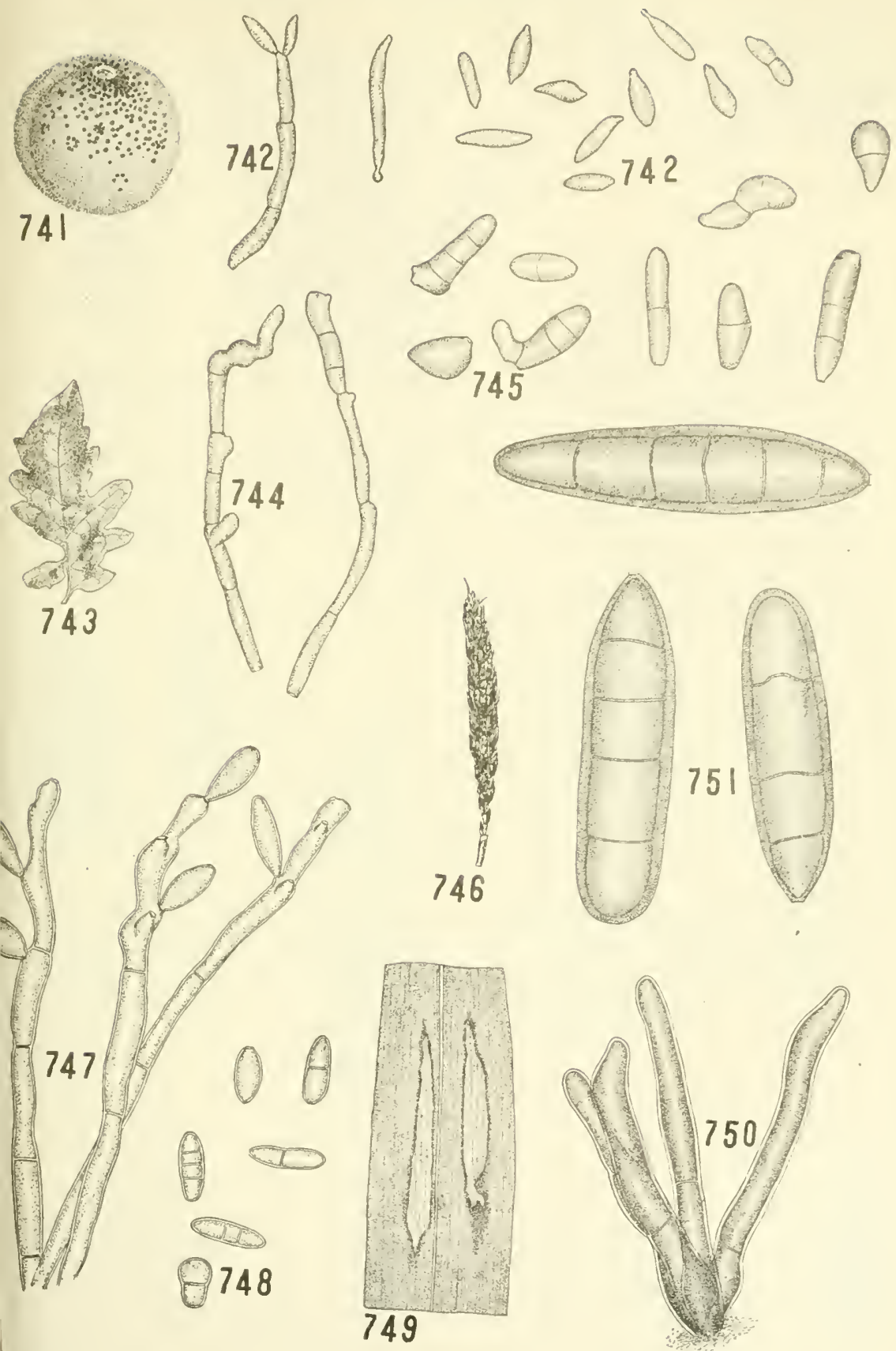


Heterosporium gracile (Wal.) Sacc.-On leaves of $I$ ris sp, and Hemerccallis fulva and other monocotyledons. Causes elliptical, light brown spots with brown or purple borders. Conodiophores krown to olive green, septate, nodulose, $70-170 \times 9-11 \mu$; conidia cylindrical, echinulate, brown to olive-green, $1-3$ septate, $30-80 \mathrm{x}$ $13-23 \mu$.

752. Infected part of Iris ieaf. 753. Immature coniodiophores, 1/12. 754. Mature conidiophores, 1/12. 755. Tip of conidiophores, 1/12. 756. Conidia, $1 / 12$.

Spondylocladium atrovirexs. Harz.-On the tubers of the potato. Causes blackish or olive-colored, slightly depressed spots about $2-3 \mathrm{~cm}$. in diameter, followed by a dry rot. Conidiophores solitary or in cluster, septate but not constricted, olive or brownish; conidia elongate, ovate, apex narrow, walls thick, 5-9 septate, may or may not be constricted, same color as conidiophores, $30-50 \times 6-13.3$ $\mu$.

757. Section of potato showing conidiophores and conidia on surface, $2 / 3$. 758. Conidiophore and conidia, 1/6. 759. Conidiophore, 1/6, 1/12. 760. Coni dia, 1/12. 761. Germinating spores, 1/6, 1/12. 


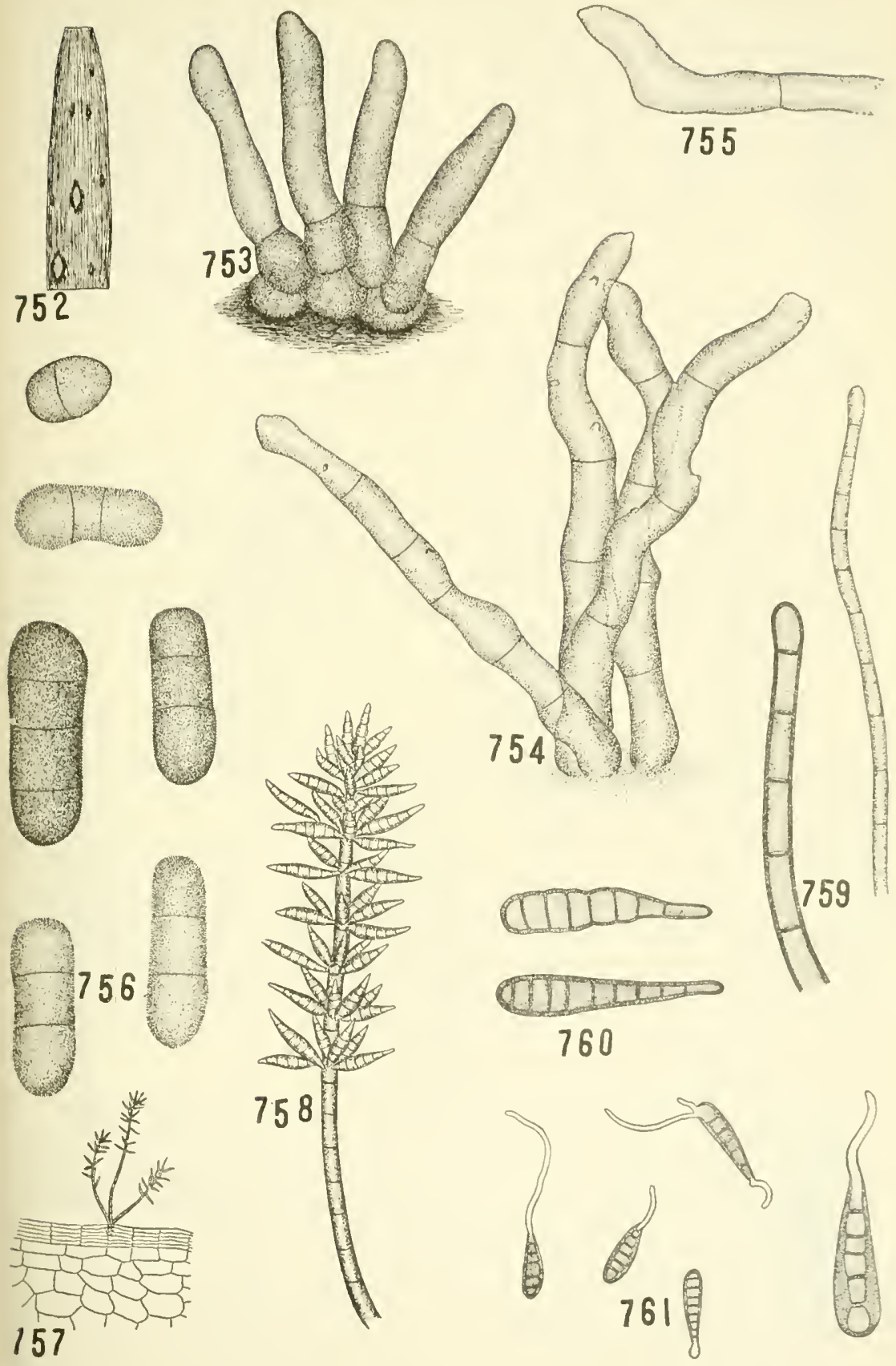


Macrosporium cucumerinum E. \& E.-On the leaves of cucumbers and muskmelons. Causes orbicular, sometimes confluent, rustycolored or whitish spots about 3-4 mm. in diameter. Conidiophores solitary or fascicled, brown, flexuous, somewhat branched, 1-8 septate, $57-140 \times 5-9 \mu$ in length, $5-9 \mu$ in diameter at base and $4.6 \mu$ in diameter at tip; conidia numerous, club-shaped, brown, multi-septate, $57-81 \times 11-24 \mu$, with long beak having a hyaline tip.

762. Infected leaf of Cucumis melo. 763. Conidium, 1/12.

Macrosporium herculeum E. \& M.-On leaves of turnips, horse-radish and other crucifers. Causes gray to brown spots. Conidiophores erect, fexuose, few septate, $70-80 \times 5 \mu$; conidia brown, multi-septate, clavate, $139.8-225 \times 18.2-23 \mu$.

764. Spots on portion of turnip leấ. 765. Conidium, 1/12.

Alternaria abutilonis* Speg.-On the leaves of Abutilon abutilon. Causes irregular brown spots visible on both surfaces of the leaf. Conidiophores branched, smoky to hyaline; conidia clubshaped, muriform, pale yellowish to smoky, 5-7 septate, 50-9 $\mathrm{x}$ $10-15 \mu$.

\section{Conidium, 1/12.}

Alternaria Brassice (Berk.) Sacc.-On the leaves of cabbage, collards and other crucifers; causing black mold. Conidia clavate, 5-11 septate, $50-60 \times 12-14 \mu$.

\section{Conidia, 1/6, 1/12.}

Alternaria cucurbites Let.-On the leaves of cucumbers and melons. Causes circular spots which frequently become confluent and cover the entire leaf. Conidiophores short, straight, brown; conidia multi-cellular, clavate, olive-colored, $60-68 \times 8-9 \mu$.

\section{Conidia, 1/12.}

Alternaria solani (E. \& M.) Jones \& Grout.-On the leaves of the potato and tomato. Causes brown, more or less circular, concentrically-zonated spots. Conidiophores septate, $50-90 \times 8-9 \mu$; conidia obclavate, brown, transverse septa numerous, longitudinal septa few, beak long, hyaline, $145-370 \times 16-18 \mu$.

769. Infected potato leaf. 770. Germinating conidium, 1/12.

*Syn. Macrosborium ahutilonis. 


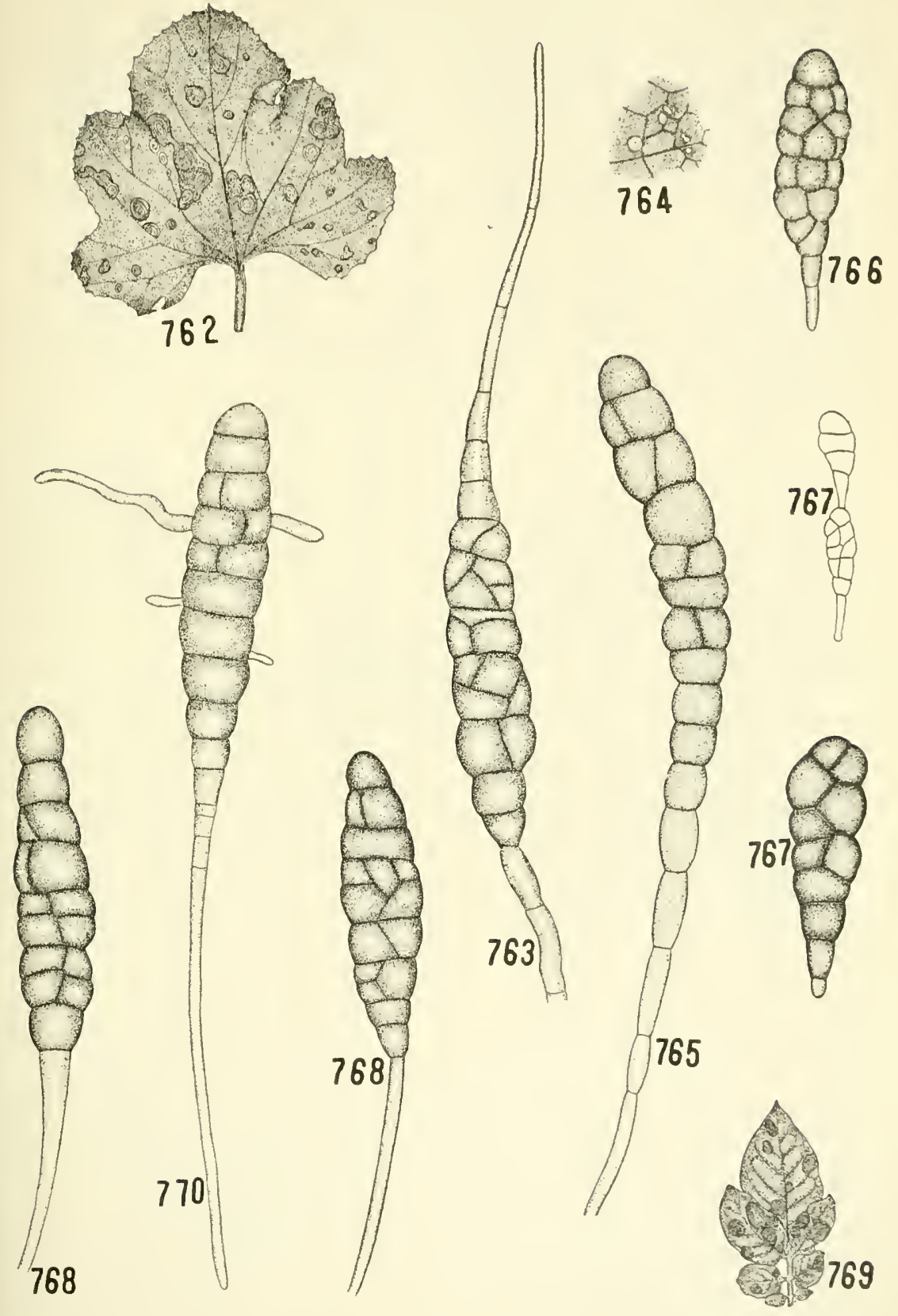

(5) 
Cercospora ACAlyph e Peck.-On the leaves of acalypha virginica. Causes small, very thin, circular, white spots with narrow purplish-brown borders. Conidiophores fasciculate, septate, brown, 54-75 $\times 5 \mu$; conidia cylindrical, attenuated at distal end, 5- 8 septate, hyaline, $50-100 \times 3 \mu$.

771. Infected leaf of Acalypha virginica. 772. Conidiophore and conidium, $1 / 12$.

Cercospora ageratoides E. \& E.-On Eupatorium album, E. ageratoides, etc. Causes brown, subangular spots bounded by veinlets, becoming confluent, $1-3 \mathrm{~mm}$. ; conidiophores in tufts, brown, unbranched, septate, $50-90 \times 4 \mu$; conidia cylindrical or lanceolate, 1- 6 septate, $40-75 \times 3.5-5 \mu$.

773. Conidia, 1/12.

Cercospora altheina Sacc.-On leaves and stem of hollyhock and some other Malvacea, causing brown spots. Conidiophores, clive brown, fasciculate, slender, few-septate, $40 \times 5 \mu$; conidia apical, hyaline, cylindric to obclavate or broadly fusoid, straight, apically obtuse, $2-9$ septate, $40-60 \times 5 \mu$.

774. Infected leaf of Malva sp. 775. Conidiophores, 1/12. 776. Conidia, 1/12.

Cercospora anthelmintica Atk.-On the leaves of Chenopodinm ambrosioides var. anthelminticum. Causes small, light brown, circular spots with broad reddish border, $1-3 \mathrm{~mm}$. in diameter. Conidiophores fasciculate, dentate, septate, almost hyaline, 30-100 $\times 4-4.5$ $\mu$; conidia cylindrical, septate, hyaline, $25-100 \times 4-4.5 \mu$.

777. Infected leaf of Chenopodium ambrosiodes var. anthelminticum. 778. Conidiophores, 1/12. 779. Conidium, 1/12. 
Parasitic Fungi of New Tersey

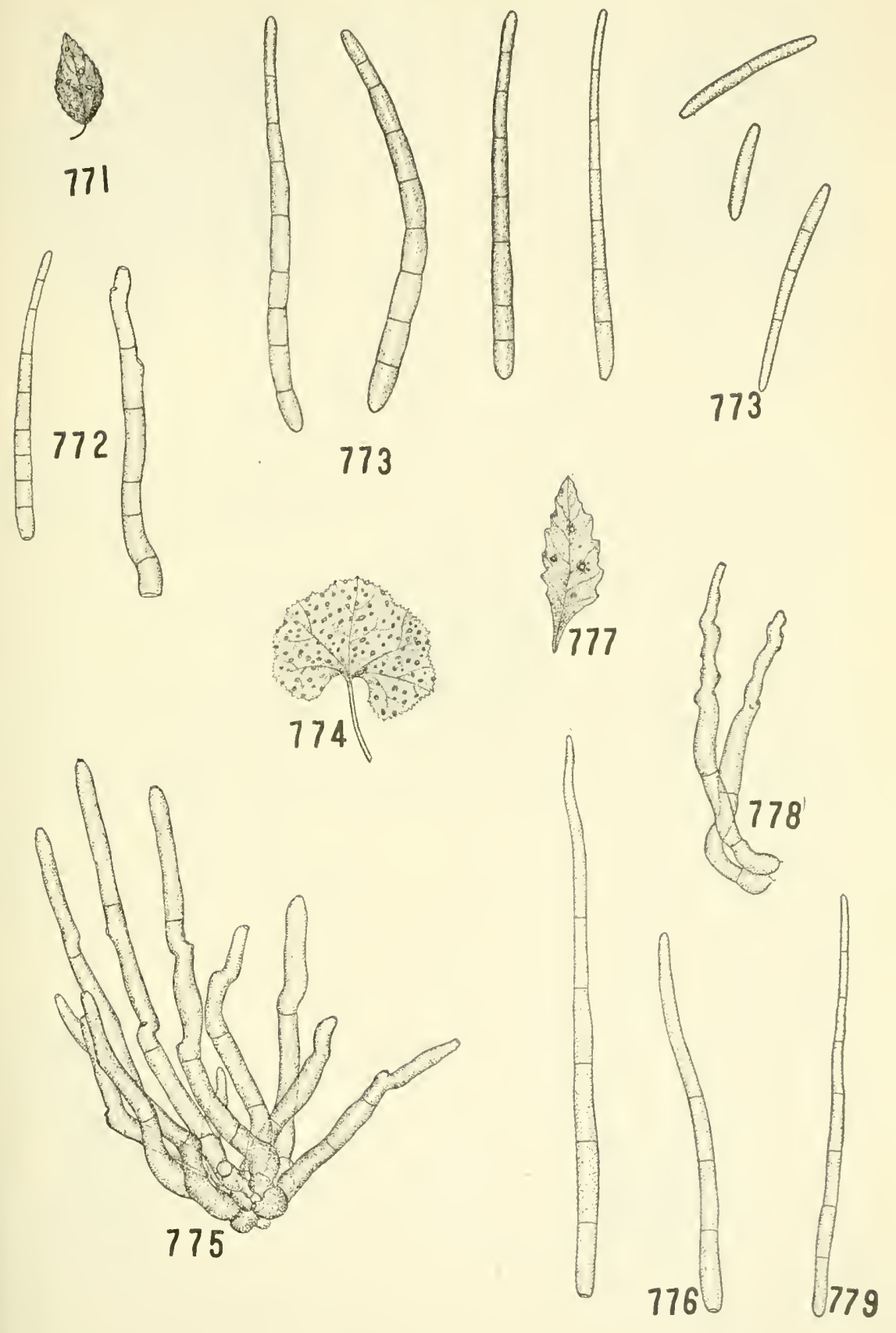


Cercospora apil Fr.-On the leaves of celery, parsnips, etc. Causes a serious leaf-spot disease. Spots on any part of the leaf, mostly at apex, at base of main serrations, or at side of basal portion of the leaf; varies in character with location and humidity, yellowish, becoming large and ashy-gray, frequently surrounded by a halo of yellow, often becoming confluent. Spots on petioles greenish-gray, elongating in the direction of the axis. Conidiophores on both surfaces of the leaf, fascicled, light brown, subundulate, non-septate or 1- or 2-septate, 40-100.4 × 4-7.5 $\mu$; conidia hyaline, or light brown, clavate or slightly curved towards apex, 3-16 septate, 50-215.7 x 4-7.7 $\mu$.

(Written from notes by Mr. W. S. Krout.)

780. Infected leaflet of celery. 781. Conidia, 1/12.

Cercospora armoracex Sacc.-On leaves of horse-radish. Causes pale spots on both surfaces of leaves. Conidiophores short, simple, septate, $30-40 \times 5 \mu$; conidia long and tapering, hyaline, many septate when mature, $100-120 \times 5 \mu$.

782. Part of infected leaf of horse-radish. 783. Conidiophores, 1/12. 784. Conidia, $1 / 12$.

Cercospora leticola Sacc.-On the leaves of the beets and chard. Causes brownish, purple-bordered spots which develop ashy centers with age. Conidiophores fasciculate, short, erect, non-septate, 35-55 x 4-5 $\mu$; conidia long, filiform, obclavate, multi-septate, hyaline, $75-200 \times 3.5-4 \mu$.

785. Part of infected leaf ố beet. 786. Conidiophores and conidia, 1/12. 787. Conidia, 1/12. 

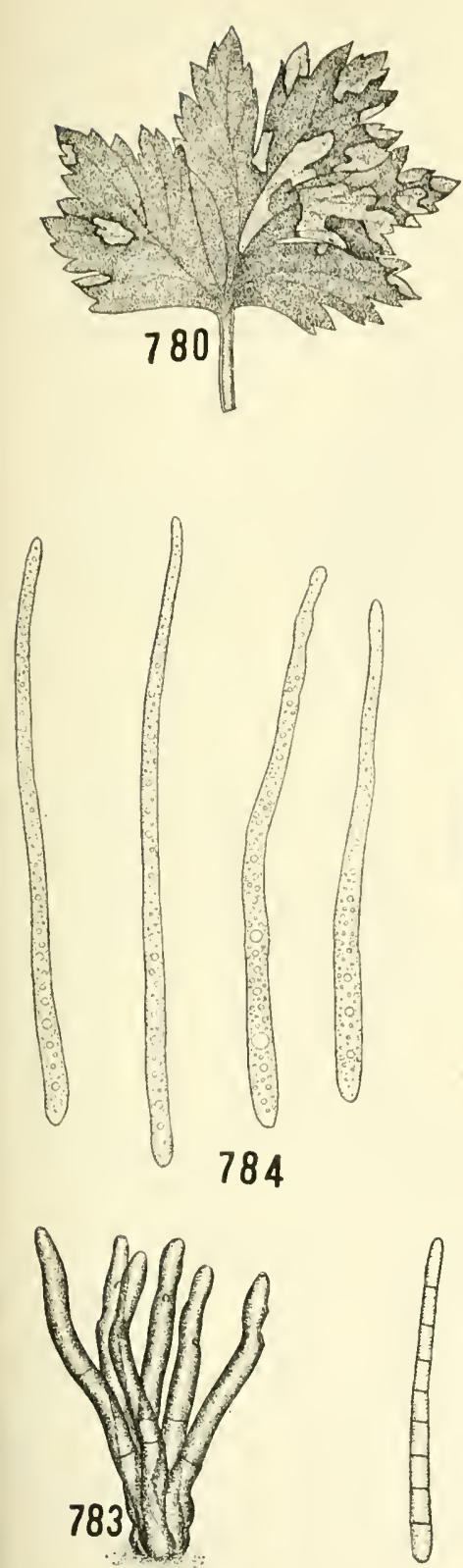
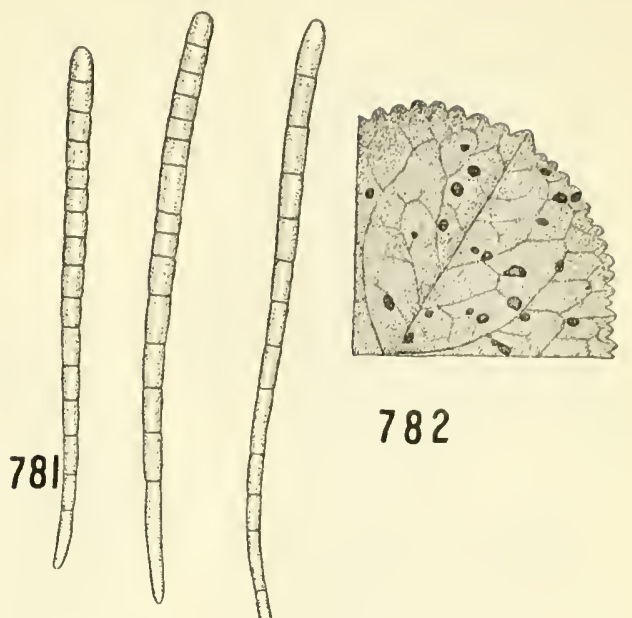
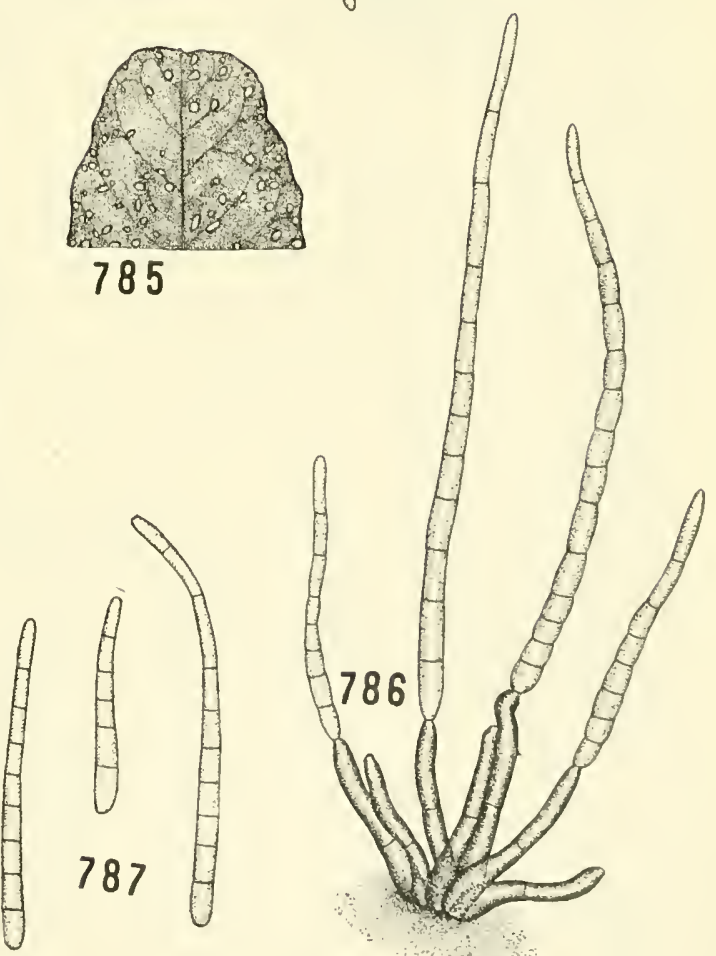
Cercospora canescens E. \& M.-On the leaves of garden beans. Causes broad, irregular brown spots with yellowish-brown borders; conidiophores brown; conidia hyaline, cylindric-clavate, 5-many septate, $117 \times 6 \mu$.

$$
\text { 788. Conidia, 1/12. }
$$

Cercospora CERcidicola Ell.-On the leaves of the American red bud (Cercis canadensis). Causes spots with dark, raised margins which are dull gray above and rusty brown below. Conidiophores fasciculate, brown, wavy, multi-septate, $90-114 \times 3.5-4 \mu$; conidia clavate, 3 -septate, $30-40 \times 4-7 \mu$.

789. Infected leaf of Cercis canadensis. 790. Conidiophores, 1/12. 791. Conidia, $1 / 12$.

Cercospora chionanthi E. \& E.-On the fruit of Chionanthus virginica. Also reported on the leaves. Causes a rotting and shrivelling of the fruit and spotting of the leaves. Conidiophores fasciculate, brown, septate, geniculate at distal end or somewhat wavy, $75-150 \times 3.5-5 \mu$; conidia fusoid or club-shaped, dark at maturity 3-5 septate, $30-60 \times 4.4-5 \mu$.

792. Infected fruits of Chionanthus virginica. 793. Conidiophores, 1/12. 794. Conidia, 1/12.

Cercospora citrullina Cke.-On citron leaves. Causes numerous circular, brown spots $2-4 \mathrm{~mm}$. in diameter with purple borders. Conidiophores on upper surface of leaf, long, pale olivaceous; conidia long, tapering, multi-septate (Saccardo says "sparsely septate"), hyaline, $120-140 \times 3 \mu$. 


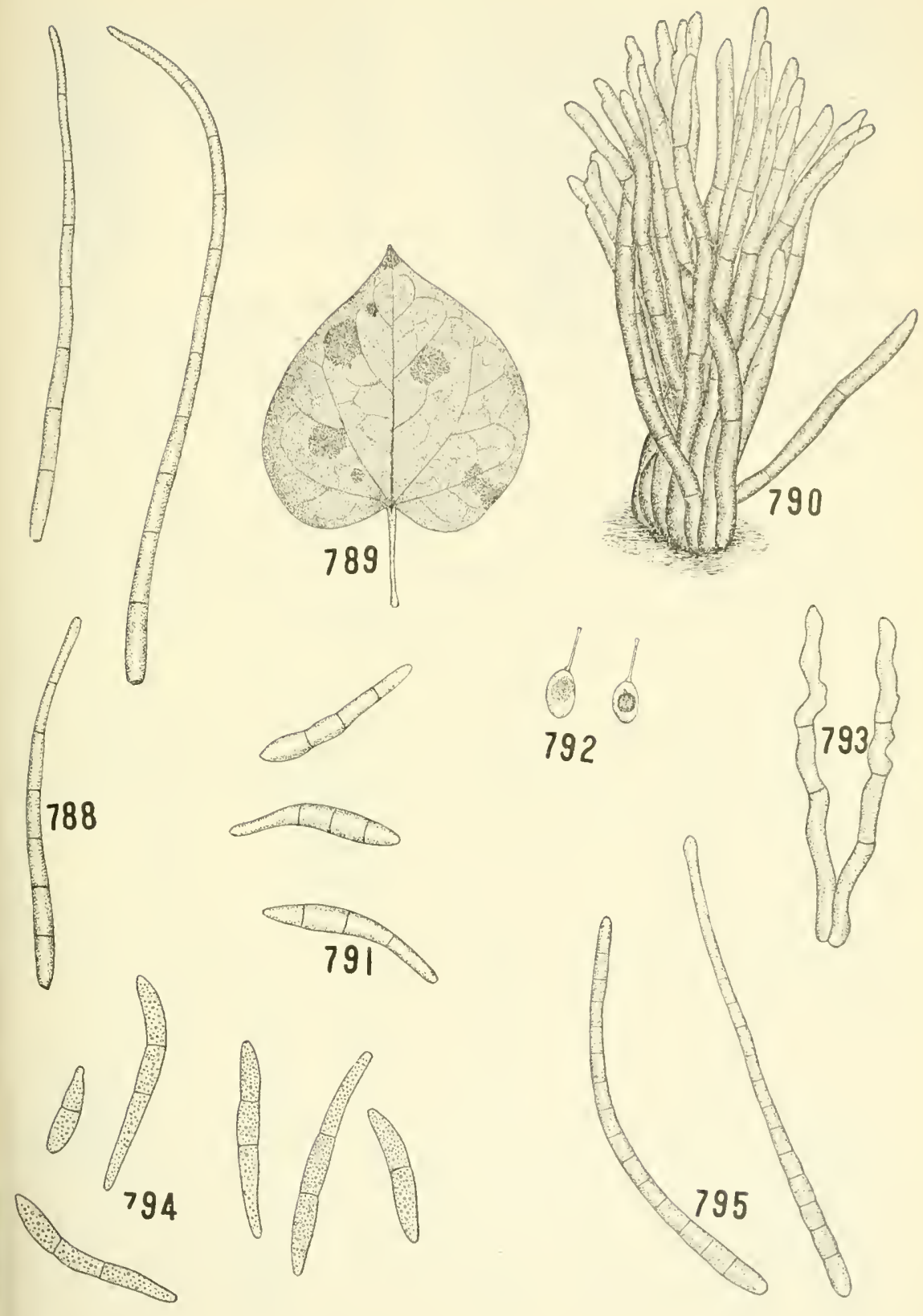


Cercospora circumiscissa Sacc.-On the leaves of peach, cherry and other drupaceous fruits. Causes circular, frequently confluent, dry spots which break and fall out, leaving a characteristic "shot hole." Conidiophores fasciculate, straight or flexuous, brownish, non-septate or occasionally 1 -septate, conidia clavate, brown, usually, 3-septate, $50 \times 3.5-4 \mu$.

796. Infected leat of peach. 797. Infected leaf of Primus serotina. 798. Conidiophores, 1/12. 799. Conidia, 1/12.

Cercospora clavata (Ger.) Peck.-On the leaves of the milkiveed (Asclepias cormuti). Causes numerous minute, irregular often confluent spots. Conidiophores densely fasciculate, light brown, non-septate, $26-38 \mu$ long ; conidia elongated, clavate, usually curved, 1-10 septate, $35-75 \times 5 \mu$.

S00. Conidia, $1 / 12$.

Cercospora cruenta Sacc.-On the leaves and stems of cowpeas and beans. Causes reddish spots. Conidiophores fasciculate, pale olivaceous, non-septate; conidia long and tapering, hyaline becoming olivaceous, multi-septate, $60-80 \times 4 \mu$.

801. Conidia, 1/12.

Cercospora diodif. Cke.-On leaves of Diodia teres. Causes orLicular leaf spots. Conidiophores on the under surface of the leaf, fasciculate, erect, septate, dark or olivaceous, $60-80 \mu$ long; conidia long and tapering, septate, $60 \times 4-4.5 \mu$.

802. Conidia, 1/12.

Cercospora dolachij E. \& E.-On the leaves of cowpea. Causes reddish-brow $n$ spots becoming gray in centers. Conidiophores fasciculate, tukercular at base, indistinctly septate, olivaceous, 20-35 $\mathrm{x}$ 4-5 $\mu$; conidia, slender, obclavate, multi-septate, $50-100 \times 3.5-4 \mu$.

803. Infected leaflet of cowpea. 804. Conidia, 1/12.

Cercospora dubia (Riess) Wint.-On leaves of Chenopodium. album. Causes more or less circular spots of various sizes. Conidiophores on both surfaces, fasciculate, usually unbranched, may or may not be septate, sooty-colored, 40-45 × 5-6 $\mu$; conidia cylindrical, somewhat fusoid, obtuse at one end, more or less pointed at the other, frequently slightly curved, hyaline or slightly colored, 4-5 septate, $60-70 \times 8-9 \mu$.

805. Infected leaf of Chenopodium album. 806. Conidiophores, 1/12. 807 Conidia, 1/12. 

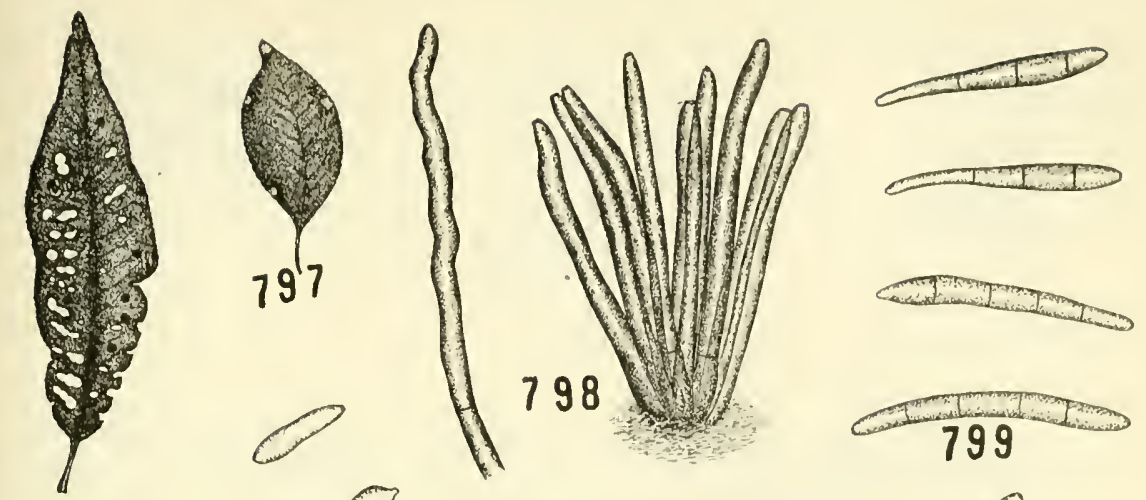

796
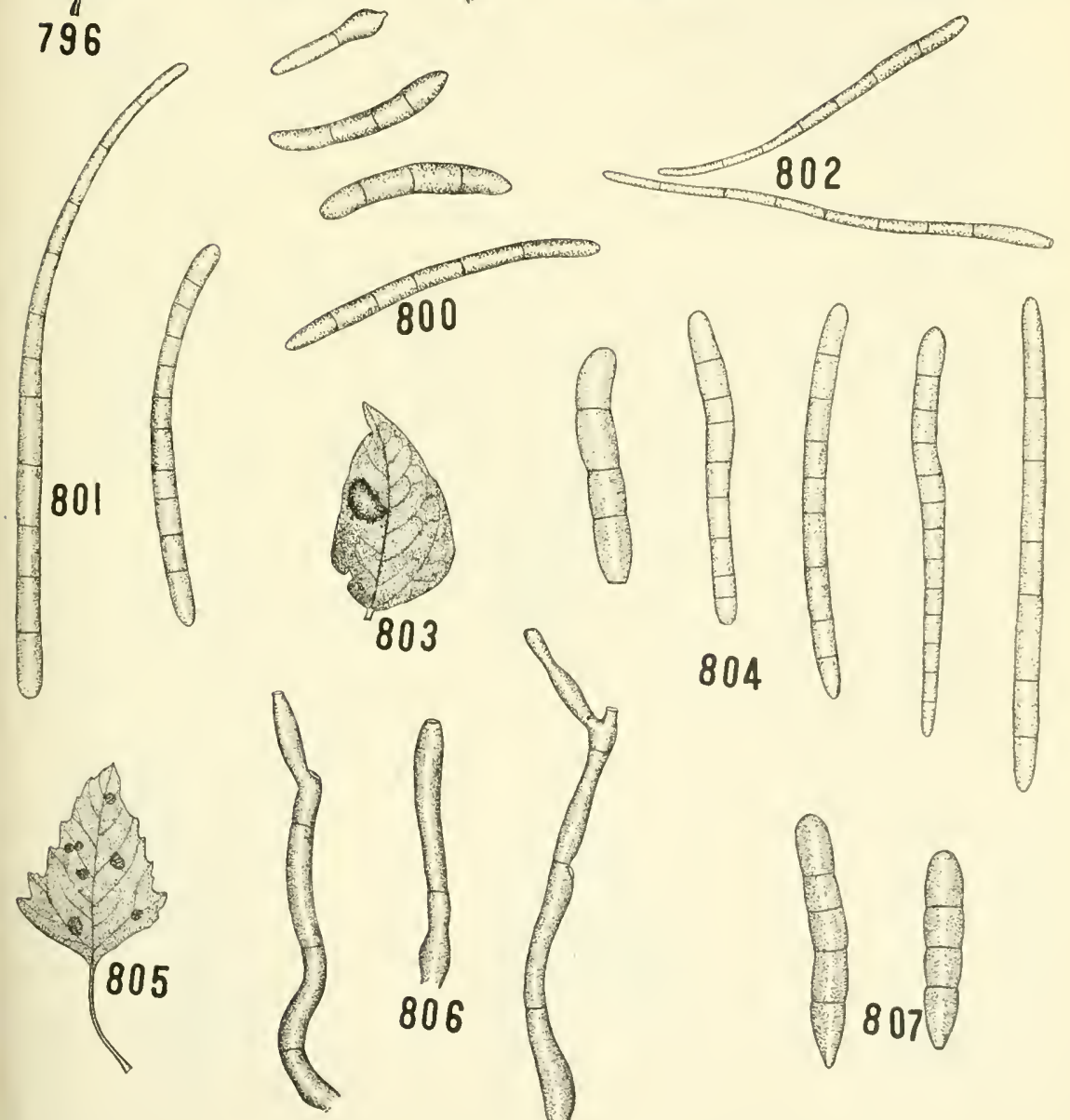
Cercospora grantliformis Ell. \& Holw.-On the leares and petiole of Viola cucullata. Causes more or less circular spots about 1 $\mathrm{cm}$. in diameter with somewhat indefinite margins. Conidiophores densely compact, brown, non-septate, nearly straight, becoming undulate, $15-25 \times 3 \mu$; conidia cylindrical, straight, brown, 1-6 septate, $17-85 \times 2 \frac{1}{2}-3 \mu$.

808. Infected violeł leaf. 809. Conidiophores, 1/12. \$10. Conidia, 1/12.

Cercospora ilicis Ell.-On leaves of Ilex glabra. Causes small brown spots, about 2-3 mm., with narrow slightly elevated margins. Conidiophores on both surfaces of leaf, slightly branched, septate, 50-70 $\mu$ long; conidia guttulate, cylindrical, hyaline, 1-3 septate, $35-50 \mu$ long.

811. Infected leaf of Ilex glabra. 812. Conidiophores, 1/12. 813. Conidium, $1 / 12$.

Cercospora anagioliæ E. \& Hark.-On the leaves of Magnolia glauca. Causes very small suborbicular spots visible on both surfaces of the leaf. Conidiophores on both surfaces fasciculate, hyaline to dark brown, septate, 25-40 $\mu$. Conidia obclavate, 3-5 septate, $20-40 \mu$ long.

814. Part of infected magnolia leaf. 815. Conidia, 1/12. 
Parasitic Fungi of New Jersey
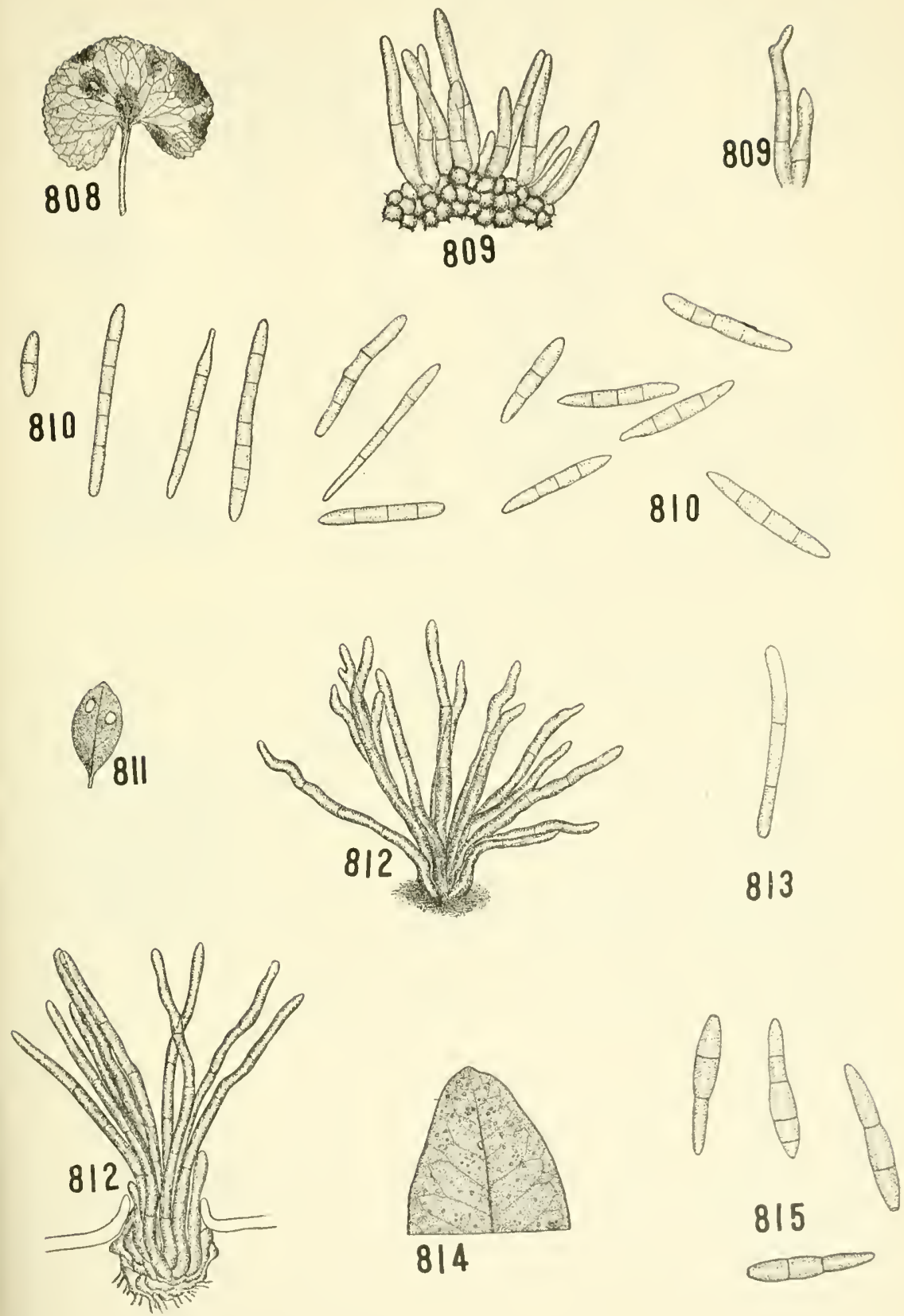
Cercospora medicaginis E. \& E.-On the leaves of alfalfa, and red and crimson clovers. Causes orbicular, more or less indefinite smoky or black spots, $3-5 \mathrm{~mm}$. in diameter on both surfaces of the leaf. Conidiophores on both surfaces, crowded on upper surface, subhyaline becoming yellowish-brown, septate, $35-45 \times 4-5 \mu$; conidia cylindrical tapering, $3-8$ septate, $40-60 \times 3 \mu$.

Note: Septa on conidia from clover fewer and farther apart.

816. Infected alfalfa leaf. 817. Conidiophores, 1/12. 818. Conidia, 1/12. 819. Infected clover leaf. 820. Conidia, 1/12.

Cercospora microsora Sacc.-On the leaves of the linden (Tilia Americana) and other species of Tilia. Causes small, dark brown, sub-orbicular spots with light centers, which sometimes are very numerous and cover the greater part of the surface. Conidiophores fasciculate from a tubercular stroma, short, non-septate, olivaceous, almost hyaline at the tips $20-30 \times 3 \mu$; conidia filiform, obclavate multi-septate, constricted at septa, olivaceous, 50-100 × $3.5 \mu$.

821. Infected leaf of Tilia Eurcpea. 822. Conidiophores, 1/12. 823. Conidia, $1 / 12$. 
Parasitic fungi of New Jersey
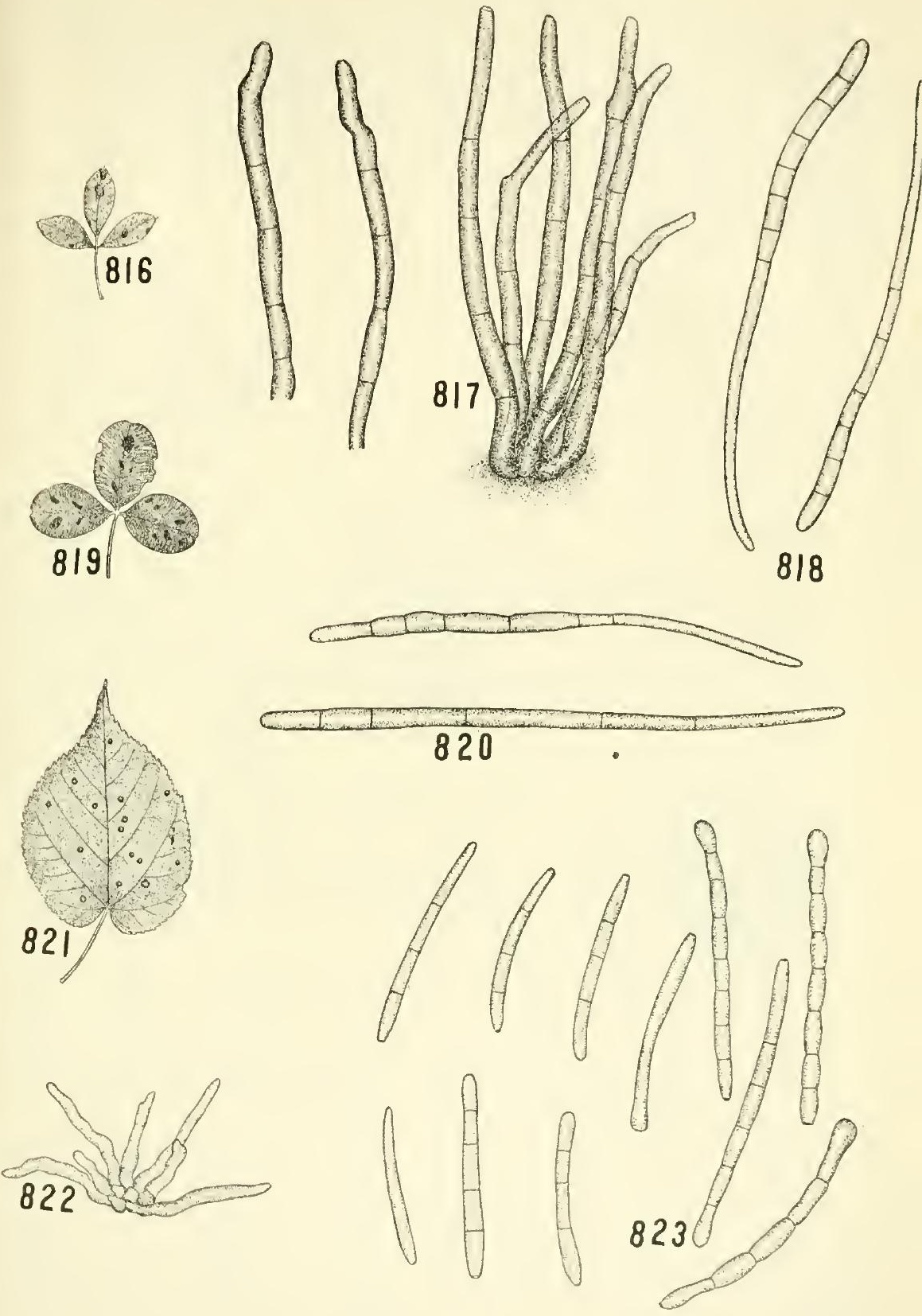
Cercospora obesa E. \& E.-On the leaves of the thistle. Causes irregular, grayish-brown, usually confluent leaf-spots, $2-5 \mathrm{~mm}$. in diameter. Conidiophores short, closely fasciculate, wavy, brown, 1septate; conidia long, tapering, smoky, 2-7 septate, 50-60 x 5-6 u.

Note: the original description probably written from examination of immature material.

\section{Conidiophores, 1/12. 825. Conidia, 1/i2.}

Cercospora rosicola Pass.-On the leaves of both wild and cultivated roses. Causes brown spots about 2-3 mm. in diameter surrounded by broad reddish border. Conidiophores in dense tufts, brown, somewhat wary, tips irregular, 20-40 × 3-5 $\mu$. Conidia cylindrical, straight or slightly curved, both ends pointed, smoke-colored. $1-4$ septate, $30-50 \times 3.5-5 \mu$.

826. Infected rose leaf. 827. Conidiophores, 1/12. 37.8. Conidia, 1/12.

Cercospora RESEDE FCl.-On the leaves of mignonette. Causes small, yellowish gray, circular or irregular spots, frequently coalescing and causing a shrivelling. Conidiophores fasciculate, simple or slightly branched, few or non-septate, light brown becoming reddishbrown, $30-80 \times 5 \mu$; conidia obclavate, 4-10 septate, $100-140 \times 2.5-3 \mu$.

829. Infected plant of mignonette. 830. Conidiophores, 1/12. 831. Conidia, $1 / 12$.

Cercospora rhuina C. \& E.-On the leaves of the sumac (Rhus copallina and $R$. glabra). Causes irregular brown spots with dark, narrow, raised border. Conidiophores fasciculate, brown, usuaily $1-$ septate, 2-4 mm. ; conidia long, tapering, brownish-tinged, 1-4 (occasionally more) septate, $40-70 \times 3 \mu$.

Note: C. rhoina as given in Saccardo is probably a typographical error.

832. Infected leaflet of Rhus glabra. 833. Conidiophores, 1/12. 834. Conidia, 1/12. 835. Conidiophore from $R$. copallina, 1/12. $\$ 36$. Conidia from same, $1 / 12$. 


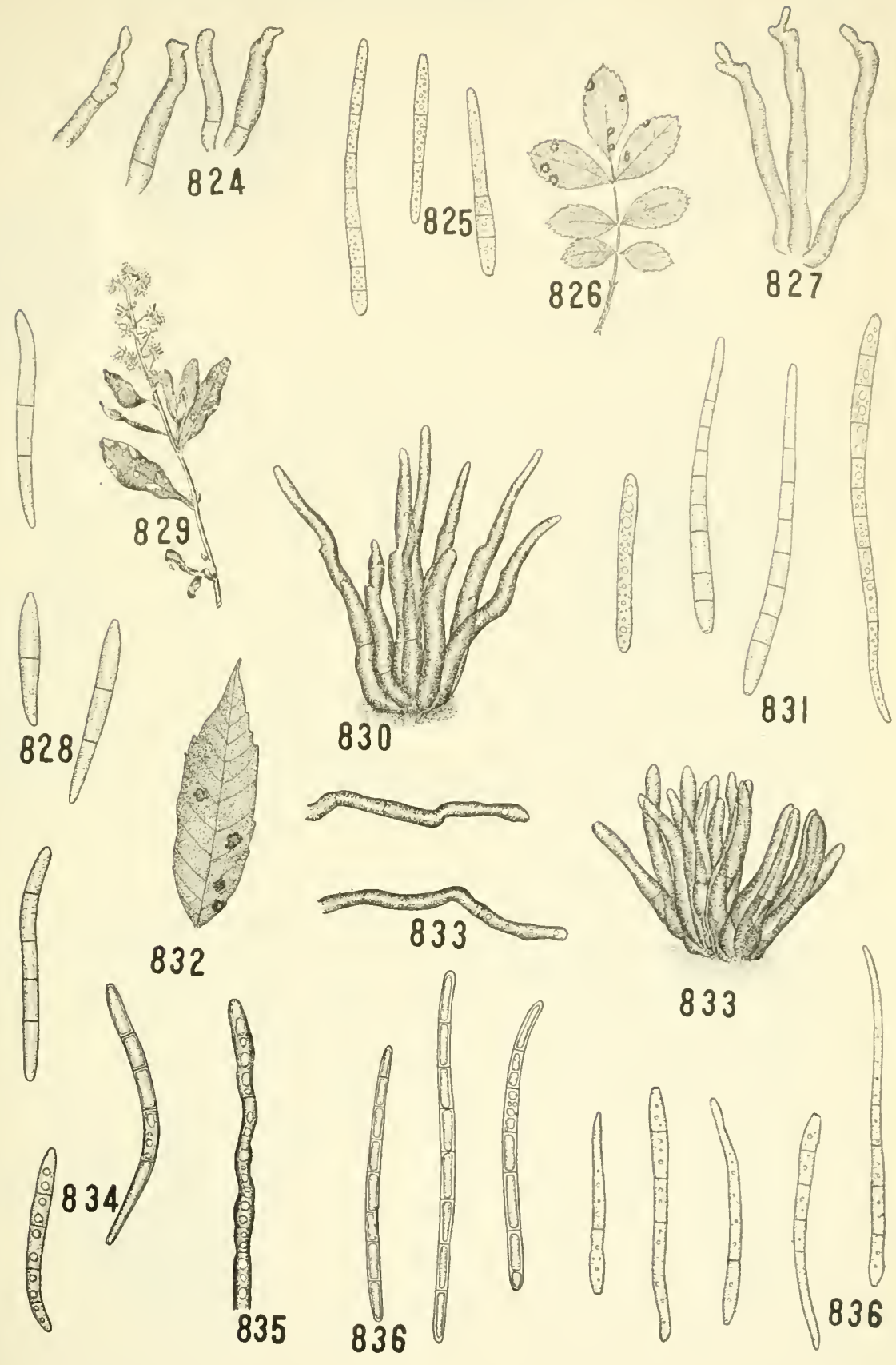


Cercospora rUbi Sacc.-On the leaves of Rubus canadensis, $R$. jructicosa and probably other species of the genus. Causes dry reddish-brown to ashy spots. Conidophores densely fasciculate, short, dark-brown, slightly branched, usually 1 - or 2 -septate, $40 \times 4 \mu$; conifia attenuated at the top, curved, multi-septate, almost hyaline, $50-100 \times 4.5 \%$.

837. Infected leaf of Rubus canadensis. 338. Conidiophores, 1/12. 839 . Conidium, 1/12. 840. Germinating conidium, 1/12.

Cercospora symplocarpi Peck.-On the leaves of Symplocarpus foetidus. Causes definite suborbicular, brown spots $0.25-0.5 \mathrm{~cm}$. broad, limited by a dark zone. Conidiophores on both surfaces of the leaf, short and dark-colored; conidia long, narrowed at tip, obclavate, pale, septate, $75-125 \mu$ long.

841. Coniodiophores, 1/12. 842. Conidia, 1/12.

Cercosrora viole Sacc.-On the leaves of violet. Causes circular, whitish, dry spots, visible on both surfaces. Conidiophores, simple or slightly branched, 30-35 $\times 4 \mu$; conidia, long, tapering, multi-septate, hyaline.

843. Infected leaf of violet. 844. Conidiophores, 1/12. 845. Conidia, 1/12. 
Parasitic Fungi of New Jersey

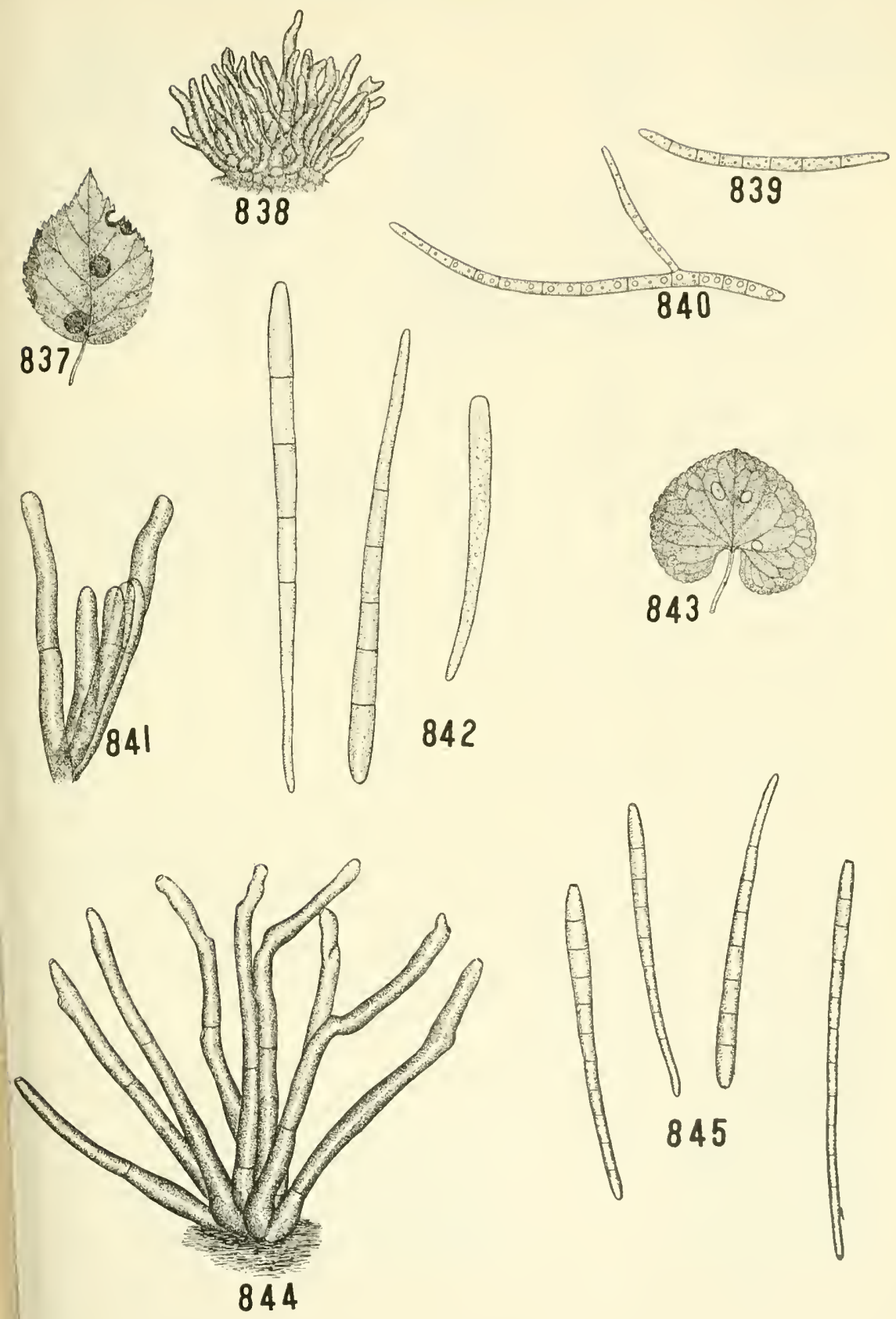


IsARIOPSIS CLAVISPORA (B. \& C.) Sacc.*-On the leaves of grape. Causes large irregular spots similar to mildew spots which become dry and ochre-colored. Conidiophores densely fasciculate, filiform. ochre-colored, septate, apex wary, 50-200 x 4-5 $\mu$; conidia elongate. obclavate, attenuate at apex, olivaceous to ochre-colored, 1-3 septate. $50-70 \times 7-8 \mu$.

846. Part of infected grape leaf. 847. Conidiophores, 1/6. 848. Conidiophores and conidia, $1 / 12$.

Tubercularia vulgaris Tode. (= Nectria cinnabarina Fries., page 34$)$.

Tuberculina persicina (Ditm.) Sacc.-On Puccinia sp. Sporodochium globose- depressed, often arranged in a circular manner, dark-violet color ; conidia globose, $7-\delta \mu$, rarely $10 \mu$ in diameter, rose to violet-colored; sporophores simple or branched, septate, apex smooth or denticulate, hyaline.

849. Sporodochium growing on a rust, 2/3. 850. Conidiophore, tips of conidiophores with conidia, $1 / 12$.

Tolutella Buxi (Cda.) Berk.-On the twigs and elaves of Buxus sempervirens. Causes spots on the under side of the leaves, dying of parts and often of the entire plant. Sporodochia grouped, minute, sessile, cushion-shaped; setæ hyaline to faint rose-colored, obtuse, septate apices, erect, diverging and surrounding the sporodochium; sporophores fasciculate, acute at apex, hyaline, $15-20 \times 2.5 \mu$. Conidia oblong, fusoid, hyaline to rose-colored, $10 \times 3.5-4.5 \mu$.

851. Infected leaf of boxwood. 852. Sporodochia, conidiophores, conidia and bristles, $1 / 6$ and $1 / 12$. 853. Conidia, $1 / 12$, from three different sources.

*Syi1. Cercospora viticola (Ces.) Sacc.

Cereospora vitis (Lev.) Lind. 

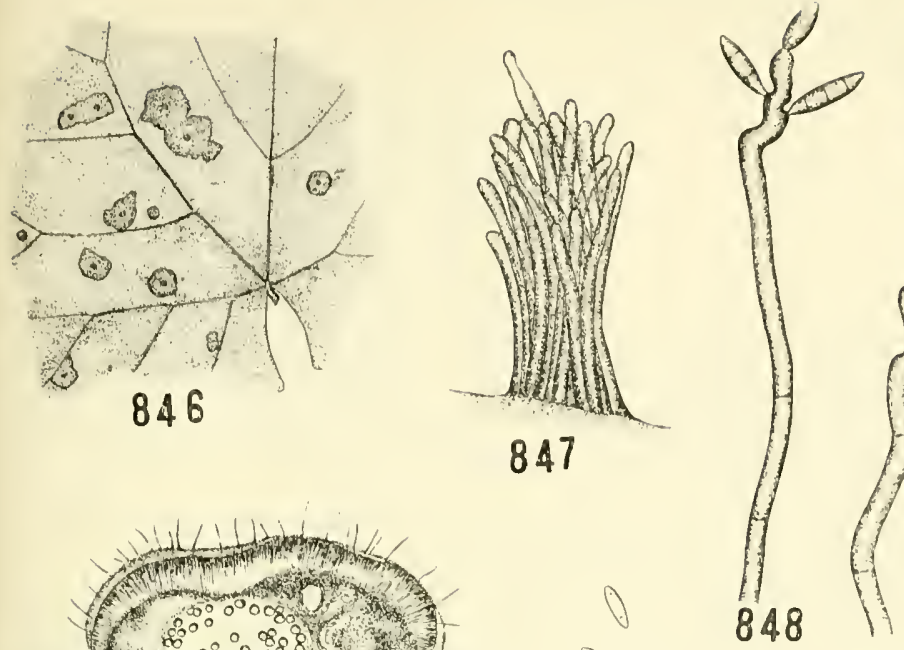

$\theta \theta$
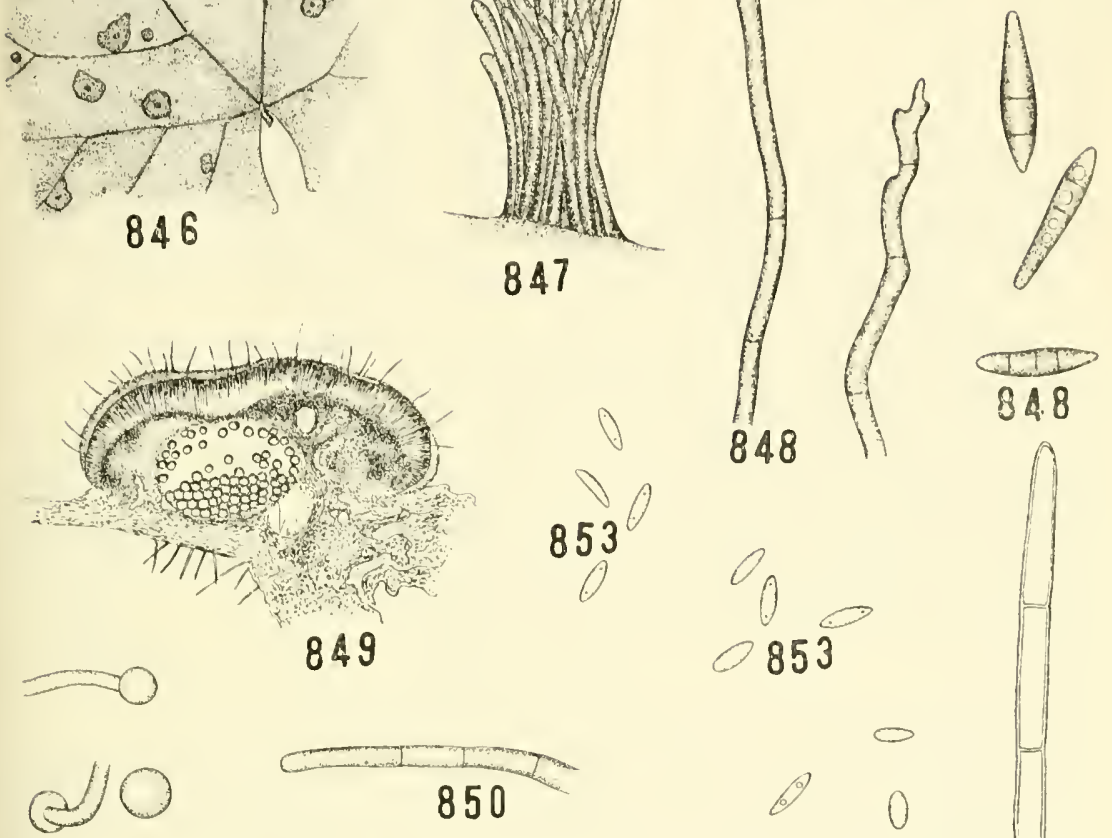

853
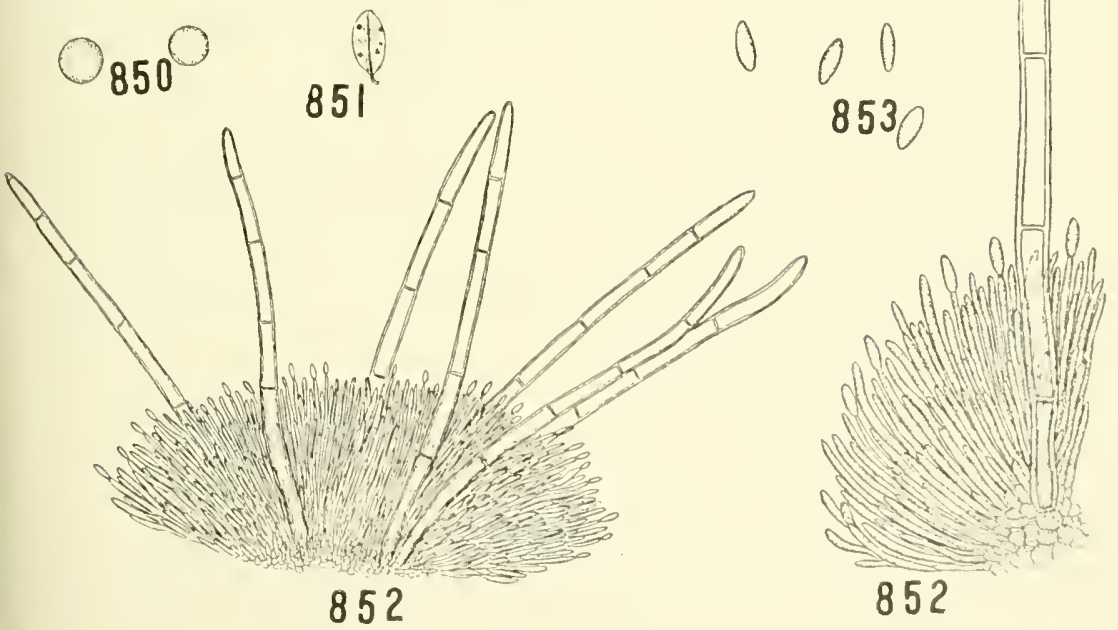
Fu'sarium Lycopersici Sacc.-In the fibro-vascular tissues of the tomato. Causes a wilting of the plant. Mycelium hyaline and variously branched, conidiophore short and simple; conidia curved, both ends acute, 1-3 septate, hyaline becoming yellowish, $25-30 \times 3.5-4 \mu$.

854. Crosi-section of fibro-vascular bundles showing mycelium, 1/6. 855 . Spores, 1/12. 856. Chlamydospores and mycelium, 1/12.

FUSARIUM RUBI ITinter.-In buds and blossoms of dewberries and blackberries. Causes deformities of the buds and flowers commonly known as "false blossoms" or "double blossoms." The conidia are produced in the opening flower buds; they are variable in size and form, straight or curved, $1-8$ septate, $14-30 \times 3-3.5 \mu$.

\section{Spores, 1/12.}

Fusarium sp. (= Nectria ipomca, page 36).

SCLEROTIUM RHIZODES Auersw. - On Calamagrostis canadensis and other grasses. Causes leaves to become dry, rigid and bent into characteristic crooks. Felty growths of mycelium appear on the leaves and give rise to sclerotia. Sclerotia at first white and woolly. Described by Stout as follows:

"SCLEROTIUM RHIZODES. - Sclerotia on host plant are rounded and smooth on their entire surface except on the side which was appressed to the leaf and here the Sclerotium is usually flattened and rugose to conform to the ridges in the surface of the leaf."

858. C. canadensis infected with Sclerotium rhizodes, showing sclerotium and characteristic shepherd's crooks. 
Parasitic Fungi of New Jersey
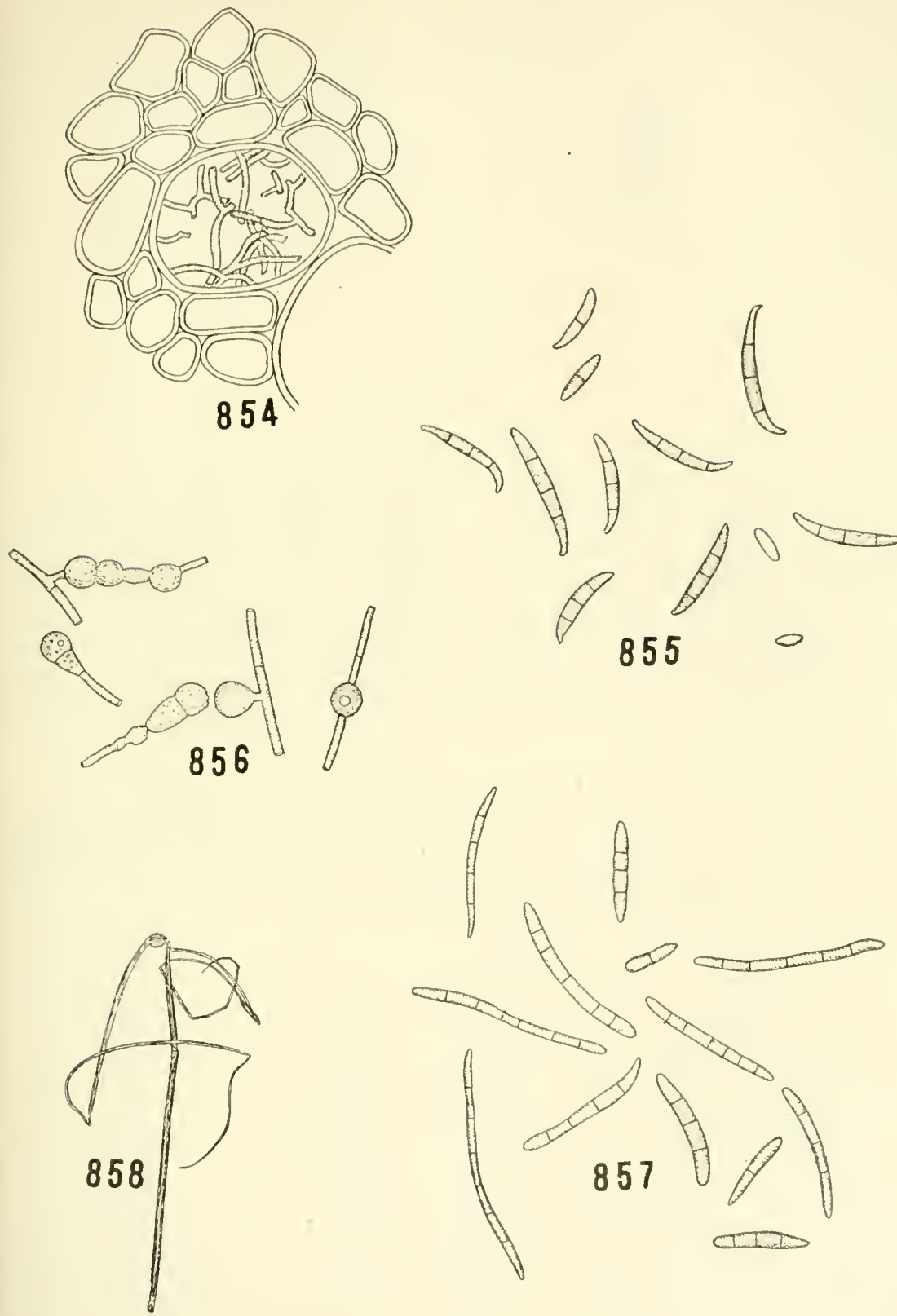
Sclerotium bataticola Taub.-On the living roots of sweet potatoes. Causes the charcoal rot. Described by Taubenhaus as follows: "Sclerotia jet black, very minute; exterior smooth, made up of anastomosed black hyphæ; interior light to dark brown, made up of free thick-walled, cortical, hyphal cells ; sclerotia vary much in sliape, spherical, oval, oblong, elliptical, curved or even forked, varying in size from $25 \times 22.4 \mu$ to $152 \times 32 \mu$, abundant throughout the interior root of the host.

Parasitic on living roots of sweet potato, Ipomoea batatas.

859. Mass of sclerotia, 2/3. 860. Single sclerotium attached to mycelium, 1/6. 861. Fusion of mycelia, 1/6. 862. Irregular cell formation in mycelia, 1/6. 863. Stages in formation of sclerotia, 1/6. 

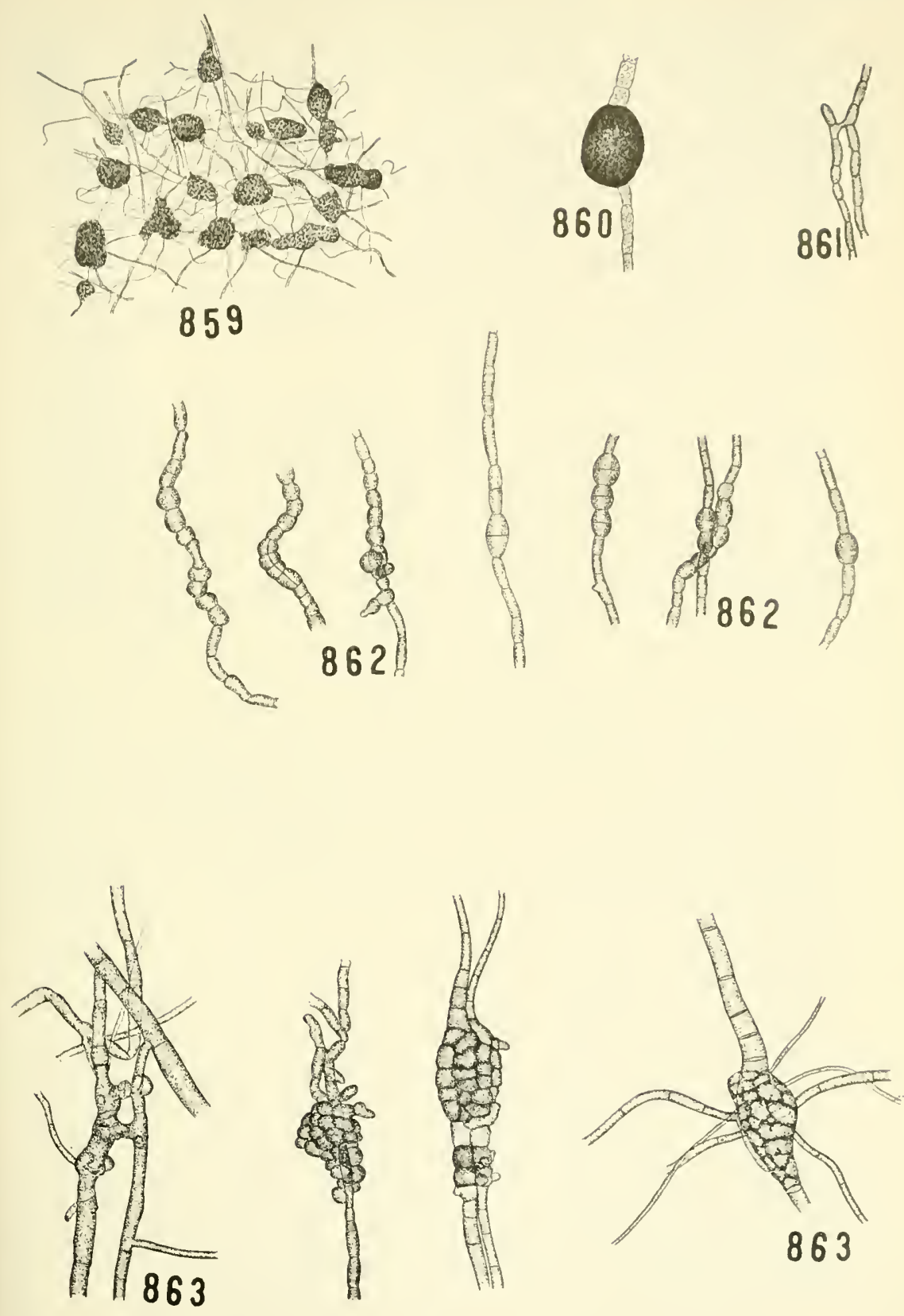
Rhizoctonia solani Kühn.-Very common on potatoes, tomatoes and carnations. Also reported on asparagus, alfalfa, horse-radish and many other plants. The cause of some very severe root and stem rots. Mycelium tufted, brown, closely septate, constricted at septa, frequently branching almost at right angles becoming yellow with age. Sclerotia variable in size, soft, white, becoming brown to black, composed of irregular and barrel-shaped cells. Sclerotia break into small masses whose cells function as chlamydospores.

864. Infected root of alfalfa. 865. Infected root or horse-radish. S66. Mycelium and cell formation from potato, 1/12. 867. Same from potato, 1/6. 868. Same from asparagus, 1/12.

Ustilago anomala J. Kunze-On inflorescence of Polygonum cilinode. "Sori in ovaries or essential organs, the infected parts of ten remaining distinct, 2-3 mm. in length, protected by the perianth, forming a dusty purplish spore-mass, spores light violet, chiefly ovoid to spherical or occasionally somewhat irregular, with rather fine reticulations (chiefly $1-3 \mu$ wide by $1 \mu$ deep), $10-15 \mu$, rarely $17 \mu$ in length." North American Flora, v. 7, p. 22 (1905).

869. Infected inflorescence of $P$. cilinode. 870. Spores, 1/12.

Ustilago AVEN瓜 (Pers.) Jens.-On inflorescence of cultivated oats. "Sori in spikelets, forming a dusty olive-brown spore mass. about 6-12 mm. long by half as wide, usually rather completely destroying the floral parts, eventually becoming dissipated, rarely in leaves; spores lighter-colored on one side, subspherical though often more elongate, minutely echinulate, 5-9 $\mu$ in Iength." North American Flora, v. 7, p. 7 (1906).

871. Infected oat plant. 872. Spores, 1/12. 873. Basidiospore, 1/12. 874. Germinating spores, 1/12.

Ustilago heufleri Fel.-On the leaves of Erythronium americanum. "Sori in leaves, forming conspicuous rounded or often elongate pustules, covered by a thin whitish membrane which upon rupture discloses a somewhat dusty black spore-mass; spores dark reddish-brown, ovoid or orate to spherical, usually regular thickwalled, smooth but inner wall provided with more or less evident projections extending into outer lighter-colored part, 13-22 $\mu$ in length." North American Flora, v. 7, p. 20 (1906).

875. Infected leaf of E. americanum. 876. Spores, $1 / 12$.

USTILAGO HORDEI (Pers.) K. \& S.-On inflorescence of cultivated barley. "Sori in spikelets, forming an adhering purple-black spore- 
Parasitic Fungi of New Jersey
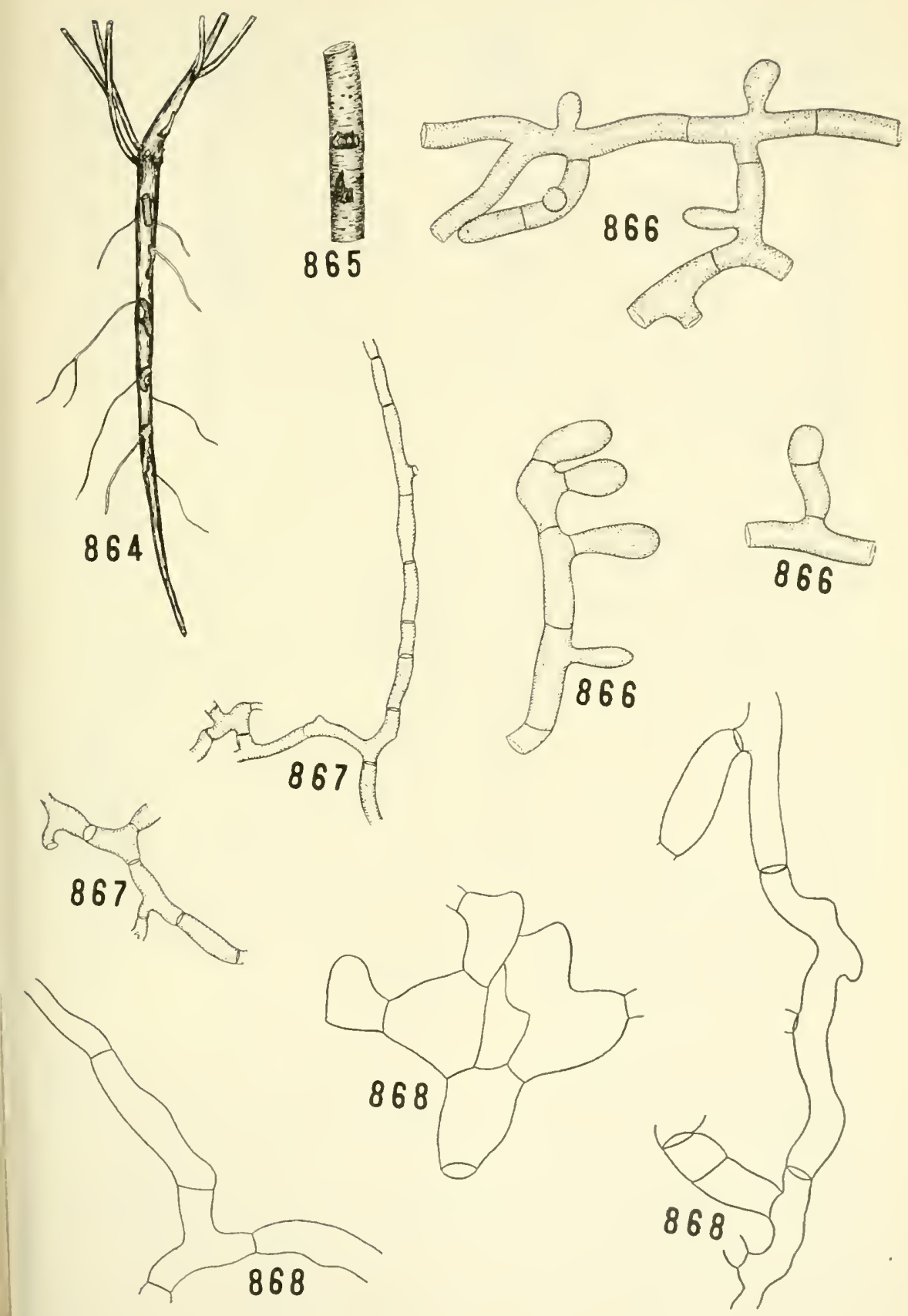
mass, about 6-10 mm. in length, covered rather permanently by the transparent basal parts of the glumes; spores lighter-colored on one side, usually subspherical or spherical, smooth 5-9 $\mu$, the most elongate rarely 9-11 $\mu$, in length." North American Flora, v. 7, p. 5 (1906).

877. Infected head of barley. 878. Spores, 1/12.

Ustilago levis (K. \& S.) Magn.-On inflorescence of cultivated oats. "Sori in spikelets forming a black-brown spore-mass, sometimes small and entirely concealed by the glumes but usually evident and destroying and inner basal parts; spores lighter-colored on one side, subspherical to spherical or rarely more elongate, smooth, 5-9 $\mu$, the most elongate rarely $11 \mu$, in length." North American Flora, v. 7, p. 7 (1906).

879. Infected head of oats. 880 . Spores, 1/12.

Ustilago Neglecta Niessl.-On the foxtail grass. "Sori in spikelets infecting all of the spike, ovate, $2-3 \mathrm{~mm}$. in length enclosed by glumes, soon rupturing and disclosing a dusty dark-brown sporemass; spores dark brown, usually ovoid to spherical or sometimes more elongate, prominently and abundantly echinulate, chiefly 10-14 $\mu$ in length." North American Flora, v. 7, p. 16 (1906).

881. Infccted head of foxtail grass. 882. Spores, 1/12.

Ustilago NudA (Jens.) K. \& S.-On inflorescence of cultivated barley. "Sori in spikelets forming a dusty olive-brown spore-mass, about $6-10 \mathrm{~mm}$. long by half as wide, temporarily protected by a thin membrane but soon becoming dissipated and leaving the naked rachis behind; spores lighter-colored on one side, minutely echinulate, subspherical to spherical or occasionally more elongate, 5-9 $\mu$ in length." North American Flora, v. 7, p. 8 (1906).

883. Infected head of barley. 884. Spores, 1/12.

Ustilago perenNans Rostr. - On inflorescence and leaves of Arrhenatherum clatius. "Sori in spikelets, forming a black-brown adhering spore-mass, sometimes small and entirely concealed by the glumes but usually evident and destroying inner and basal parts: spores lighter-colored on one side, spores subspherical to spherical or rarely more elongate, smooth, $5-9 \mu$, the most elongate rarely $11 \mu$ in length." North American Flora, v. 7, p. 7 (1906).

885. Healthy head of $A$. clatius. 886. Infected head. 887. Spores, 1/12. 
Parasitic Fungi of New Jersey

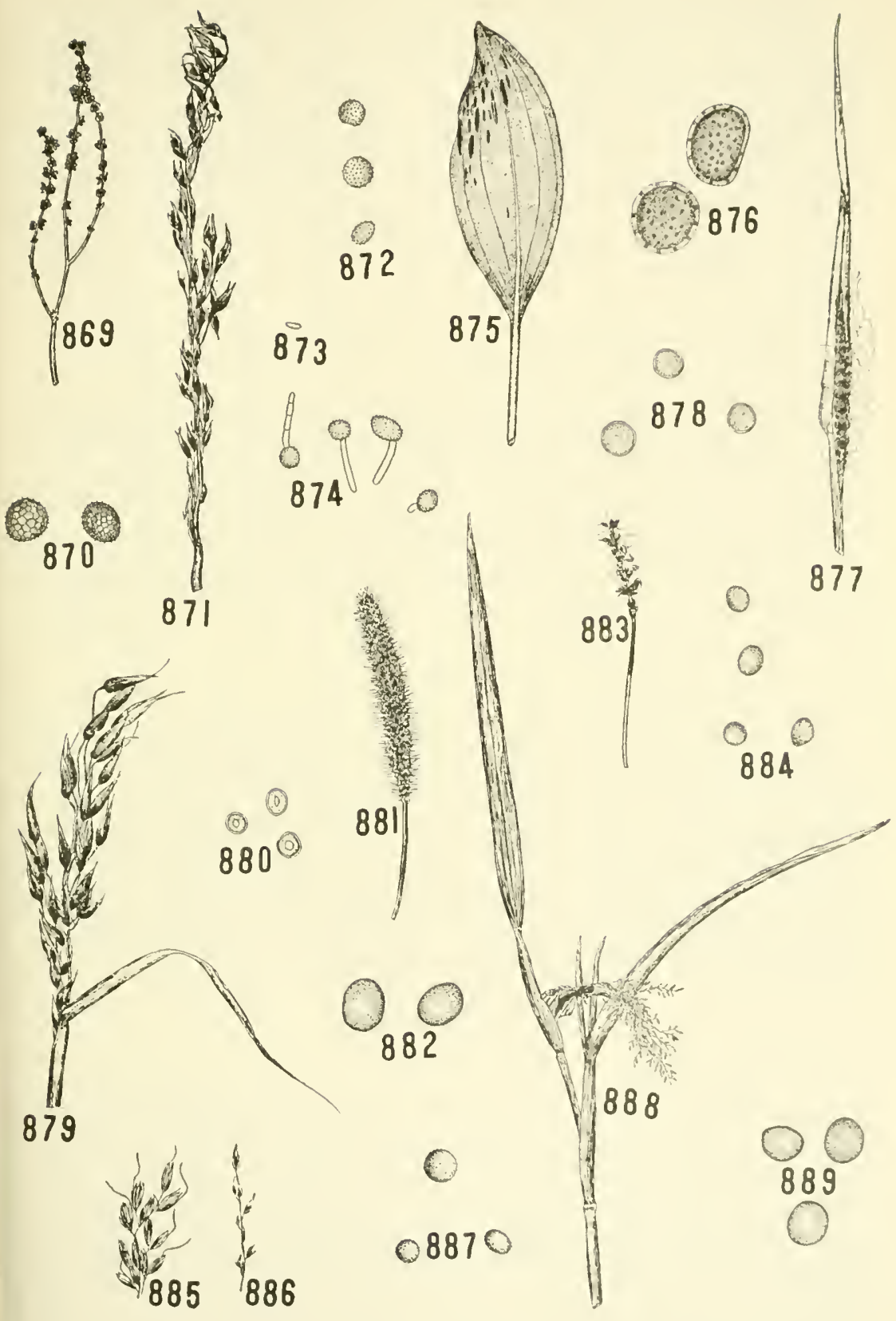


Ustilago pustulata T. \& E.-On the inflorescence of Panicum froliferum. "Sori usually in ovaries, sometimes also in stamens, forming ovate bodies about $2-4 \mathrm{~mm}$. in length, occasionally in stems near nodes or at base of inflorescence and then forming more conspicuous often nodular swellings one to several centimeters in length, with dehiscence of the thin smooth membrane disclosing a dusty olive-brown spore-mass; spores chiefly ovoid to spherical, occasionally more irregular, usually prominently echinulate, 9-12 $\mu$, the most elongate rarely $15 \mu$, in length." North American Flora, v. 7, p. 14 (1906).

888. Infected inflorescence of $P$. proliferum. 889. Spores, 1/12.

USTILAGO RABENHORSTIANA Kühn.-On the inflorescence of crabgrass. "Sori usually involving the entire inflorescence, linear-oblong, $3-5 \mathrm{~cm}$. in length, at first hidden by the enveloping leaf-sheaths but finally more or less visible as a black-brown dusty mass of spores surrounding the elongate remnants of the inflorescence; spores reddish olive-brown, ovoid to spherical or occasionally somewhat angled, echinulate or verruculose, usually 10-14 $\mu$ in length." North American Flora, v. 7, p. 17 (1906).

890. Infected inflorescence of 'crab-grass. 891. Spores, 1/12.

Ustilago Stri eformis (West.) Niessl.-On redtop grass. "Sori in leaves rarely in the inflorescence, from short linear often extending apparently by terminal fusion for several $\mathrm{cm}$., also occasionally fusing laterally to cover most of the leaf, at first covered by epidermis but this soon ruptured and dusty brown-black lines of spores becoming scattered and leaves shredded, spores usually ellipsoidal to spherical, occasionally irregular, prominently echinulate, chiefly 9-14 $\mu$ in length." North American Flora, v. 7, p. 18 (1906).

892. Spores, $1 / 12$.

Ustilago tritici (Pers.) Rostr.-On inflorescence of wheat. "Sori in spikelets, forming a dusty olive-brown spore-mass, about 3-12 $\mathrm{mm}$. long by half as wide, usually entirely destroying floral parts and eventually becoming dissipated and leaving behind only the naked rachis; spores lighter-colored on one side, usually subspherical, occasionally more elongate, minutely echinulate especially on the lighter side 5-9 $\mu$ in length." North American Flora, v. 7, p. 8 (1906).

893. Infected heads of wheat. 894. Spores, 1/12. 
Ustilago utriculosa (Nees.) Tul. - On the inflorescence of Polygonum pennsylvanicum.

"Sori in ovaries and probably in stamens, protected by floral envelopes, ovate, about $3-4 \mathrm{~mm}$. in length, forming a dusty purplish spore-mass; spores violet, chiefly subspherical or spherical, with prominent winged reticulations $(2-4 \mu$ wide by about $1.5 \mu$ deep), chiefly $9-14 \mu$ in diameter." North American Flora, v. 7, p. 22 (1906).

895. Infected inflorescence of $P$. pennsylvanicum. 896. Spores, 1/12.

Ustilago zex (Beck.) Ung.-On ears, tassel, leaves and stems of corn. "Sori on any part of the host, usually prominent, forming irregular swellings from a few $\mathrm{mm}$. to over a dm. in diameter, at first protected by a sort of false white membrane composed of plant cells and semi-gelatinized fungous threads, soon rupturing and disclosing a reddish-brown spore-mass; spores ellipsoidal to spherical or rarely more irregular, prominently tough rather bluntly echinulate, 8-11 $\mu$, the most elongate $15 \mu$, in length." North American Flora, v. 7, p. 15 (1906).

897. Infected inflorescence of corn. 898. Spores, 1/12.

Melanopichium austro-americanum (Speg.) G. Beck.-On stems, leaves and inflorescence of Polygonum pennsylvanicum. "Sori chiefly in the inflorescence, forming more or less irregular lobed masses arising from the fusion of the infected parts, less commonly on the leaves and then smaller, usually prominent, 2 or $3 \mathrm{~mm}$. to 2 $\mathrm{cm}$. in length, internally somewhat nodular or tubercular; forming a hard, firmly agglutinated, black, spore mass mixed with plant tissues, spores oblong to chiefly subspherical, often somewhat irregular, with more or less evident gelatinous envelope, usually rather prominently echinulate, chiefly $10-14 \mu$, the most elongate rarely $17 \mu$ in length." North American Flora, v. 7, p. 30 (1906).

899. Infected inflorescence of $P$. pennsylvanicum. 900. Infected stem of same. 901. Spores, 1/12.

Sorosporium Ellisi Wint.-On the inflorescence of Andropogon virginicus. "Sori elongate, including the entire inflorescence or more rarely confined to the individual spikelets, chiefly $1 \mathrm{~cm}$. in length, often hidden by enveloping leaf-sheaths, provided with evident false membrane, within which is the black-brown dusty spore-mass; spore balls dark-reddish brown, subopaque, rather temporary, oblong to subspherical, chiefly 40-100 $\mu$ in length, spores somewhat irregular, 
cblong to chiefly subspherical or polyhedral, thick-walled (wall often irregular thickened and lighter-colored where spores have been in contact), verruculose, chiefly $12-19 \mu$ in length." North American Flora, v. 7, p. 39 (1906).

902. Infected inflorescence of $A$. virginicus. 903. Spore balls, 2/3. 904 . Spores, $1 / 12$.

Sorosporiun syntherisma (Peck.) Farl.-On the inflorescence of Panicum proliferum. "Sori involving the entire inflorescence elongate, $3-7 \mathrm{~cm}$. in length, or rarely limited to individual spikelets and then shorter, protected by leaf sheaths, provided with false membrane that ruptures from the apex down disclosing black-brown spore mass and shredded filaments of plant tissue; sterile cells of nembrane hyaline, oblong to circular or subspherical, with tendency 10 adhere in filaments when separated, spore balls rather evanescent, variable in shape and size, irregularly oblong to spherical, $40-100 \mu$ in length, spores very minutely verruculose, inner often appearing smooth, subspherical or somewhat polyhedral to occasionally more elongate, chiefly" 9-13 $\mu$ in length." North American Flora, v. 7, p. 38 (1906).

905. Infected inflorescence of P. Proliferum. 906 Spores, 1/12.

Tilletia fetens (B. \& C.) Trel.-In the ovaries of wheat. "Sori in ovaries, ovate to oblong, $5-8 \mathrm{~mm}$. in length more or less concealed by the glumes, all or only part of the ovaries of a spike infected; sjores light to dark-brown, oblong to chiefly subspherical, occasionally somewhat angular, fœetid especially when young, smooth, chiefly 16-22 $\mu$, the most elongate rarely $28 \mu$, in length." North American Flora, v. 7, p. 48 (1906).

907. Infected head of wheat. 908. Spores, 1/12.

Tilletia TRitici (Bjerk.) Wint.-In the ovaries of wheat. "Sori in ovaries, ovate to oblong, $5-8 \mathrm{~mm}$. in length more or less concealed by the glumes, sterile cells few, hyaline; subspherical with medium thin wall, smaller than spores; spores chiefly subspherical or spherical, light to dark-brown, with winged reticulations about $1 \mu$ high by 2-4 $\mu$ wide, 16-22 $\mu$ in diameter." North American Flora, v. 7. p. 48 (1906).

909. Spores, 1/12. 910. Larger spores from anothe: specimen, 1/12. 
Cintractia Junci (Schw.) Trel.-On the inflorescence of Juncus temuis.

"Sori usually linear, surrounding peduncles and pedicels for more or less of their length, sometimes in basal parts of the flowers and even occasionally filling the ovaries, forming an agglutinated black spore-mass; sterile cells usually not evident since inconspicuous and early evanescent; spores black-brown, subopaque more or less agglutinated, somewhat compressed laterally and so appearing oblong to irregularly polygonal or subcircular according to view, minutely pitted, 14-22 $\mu$ in length." North Amreican Flora, v. 7, p. 34 (1906).

911. Infected inflorescence of Juncus tenius. 912. Spores, 1/12.

Entyloma australe Speg.-On the leaves of Physalis virginiana. "Sori in leaves, forming thin at first light-yellow but later darkercolored roundish or angular areas, usually 0.5-6 $\mathrm{mm}$. in length; spores light to reddish yellow, ovoid to spherical or slightly angled, usually with apparently thick wall, chiefly 10-16 $\mu$ in length, conidia forming withish epi- or hypophyllous growths, linear, somewhat

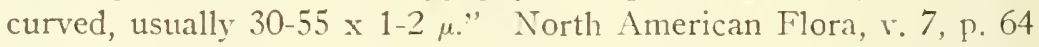
(1906).

913. Infected leaf of Physalis virginiana. 914. Spores, 1/12.

Urocystis cepule Frost.-On bulbs of Allium cepa. "Sori in leaves forming isolated pustules or often affecting them for the greater part of their length and breadth, sometimes occurring at their base in the bulbs upon rupture of covering membrane disclosing a dusty black-brown spore-mass; spore-balls ovoid to spherical, small $17-25 \mu$ in length, sterile cells tinted, ovoid to spherical, small rather completely covering the spores, usually $4-8 \mu$ in length; spores reddish-brown, ovoid to spherical, usually 1 , rarely 2 in a ball, chiefly 12-16 $\mu$ in length." North American Flora, v. 7, p. 57 (1906).

\section{Spores, 1/12.}

Urocystis occulta (Wallr.) Rob.-On cultivated rye. "Sori in leaves (especially on under side of sheaths), culm and inflorescence forming linear strix usually of great length and often merged into a continuous stratum of dusty reddish-black spore-balls; spore-balls oblong to spherical, $16-32 \mu$ in length; sterile cells often incompletely covering the spores, hyaline or yellowish-tinted, subspherical to oblong, usually with distended and uniformly thickened walls, spores 
reddish-brown, oblong to subspherical, often with sides flattened, smooth, 1 or 2 , rarely 3 or 4 in a ball, 11-18 $\mu$ in length." North American Flora, v. 7, p. 57 (1906).

916. Infected leaf of rye. 917. Infected inflorescence of rye. 918. Spores, 1/12.

Coleosporium campanule (Pers.) Lev. (= Peridermium rostrupi, E. Fischer, page 164).

"O. Pycnia amphigenous, scattered, numerous, originating between mesophyl and cortical layer, noticeable, large, 0.2-0.4 mm. wide, 1-2 mm. long, dehiscent by a longitudinal slit, $90-110 \mu$ high.

"I. Aecia from a limited mycelium, amphigenous, scattered, 1-3 on discolored spots bullate, tongue-shaped, large, 1-3 mm. long, 0.7-1.5 $\mathrm{mm}$. high, yellow fading to white; peridium rupturing irregularly, fragile, white, cells overlapping, outer and inner walls same thickness, about 4-6 $\mu$, outer smooth, inner moderately verrucose; æciospores broadly ellipsoid or globoid, $17-22$ by $22-31 \mu$; wall colorless, thin, 2-3.5 $\mu$, densely verrucose, with prominent, elongate papillæ." On Pinus rigida.

"II. Uredinia hypophyllous, scattered often confluent, $0.5 \mathrm{~mm}$. across, soon naked, orange-red fading to white, ruptured epidermis evident; urediniospores ellipsoid, $18-23$ by $20-30 \mu$; wall thin, $1-1.5 \mu$, densely verrucose, with prominent, elongate papillæ.

"III. Telia hypophyllous, scattered often confluent, small, 0.2-0.5 mm. across, slightly elevated, blood-red fading to pale brownish-yellow; teliospores with wall swelling $15-25 \mu$ thick above; contents, orange-red fading to nearly colorless, cylindrical or clavate-oblong, 17-24 by 55-85 $\mu$, rounded or obtuse at each end." On Campanula sp. North American Flora, v. 7, p. 88 (1907).

919. Lower surface of infected leaf of $C$. rapunculoides showing sori. 920. Uredospores, $1 / 12$.

Coleosporium ipomoex (Schw.) Burr.-On Ipomoce hederacea "O. Pycnia and aecia unknown.

"II. Uredinia hypophyllous, widely scattered, or somewhat clustered, $0.25-1 \mathrm{~mm}$. across, early naked, orange-yellow fading to white, ruptured epidermis usually inconspicuous; urediniospores, ellipsoid, $13-21$ by $18-27 \mu$, more or less angular and irregular; wall thin, $1-1.5 \mu$, closely and noticeably verrucose. 
"III. Telia hypophyllous, widely scattered, often confluent, pulvinate, $0.5 \mathrm{~mm}$. or less across, deep, reddish-orange fading to pale yellow; teliospores with walls swelling $20-40 \mu$ above; contents orange yellow fading to colorless, oblong, or slightly clavate, 19-23 by $60-80 \mu$, rounded or obtuse at both ends." North American Flora, v. 7, p. 87 (1907).

921. Uredospores from leaf of $I$. hederacea, 1/12.

Peridermium acicolum U. \& E. (= Coleosporium solidaginis Schw., page 162).

Melampsora meduse (Thüm.) Arthur.-On Populus deltoides. Described by Arthur as follows:

"O. Pycnia chiefly epiphyllous, scattered or somewhat gregarious, minute, punctiform, pale-yellow, inconspicuous, hemispherical, $40-80 \mu$ in diameter, half as high.

"I. Aecia chiefly hypophyllous, scattered or somewhat gregarious, small, 0.1-0.3 $\mathrm{mm}$. broad, round or oblong, pale-yellow fading to white, inconspicuous, formed between epidermis and mesophyl, soon naked, pulverulent, ruptured epidermis noticeable; æciospores globoid, $17-22 \times 24 \mu$; wall colorless, thick, $2.5-3 \mu$, minutely verrucose, with minute crowded papillæ, pores indistinct.

"II. Uredinia amphigenous, or only hypophyllous, scattered, roundish, small, 0.2-0.4 min. across, early naked, somewhat pulverulent, orange-yellow, fading to pale brownish-yellow, ruptured epidermis usually inconspicuous; urediniospores ellipsoid or obovateellipsoid, $15-18$ by 22-30 $\mu$, usually flattened laterally; wall colorless, 2.5-3 $\mu$, or up to $10 \mu$ on the flattened sides, sparsely and evenly verrucose, with fine papillæ, except on the flattened sides which are smooth; paraphyses numerous, intermixed with the spores, capitate, smooth, 40-65 $\mu$ long, head 14-25 $\mu$ broad, wall thick, 3-6 $\mu$, peripheral paraphyses thinner-walled and more clavate.

"III. Telia amphigenous or only hypophyllous, scattered, or somewhat confluent, irregularly roundish, small $0.2-0.4 \mathrm{~mm}$. across, slightly elevated, light reddish-brown, becoming deep chocolate brown, subepidermal ; teliospores prismatic, $12-15$ by $30-45 \mu$; wall smooth, cinnamon-brown, uniformly thin, $1 \mu . "$

Note: In North American Flora, v. 7, p. 98 (1907), as Uredo medusa.

922. Under side of infected leaf of $P$. deltoides. 923. Uredospore, 1/12. 924. Teleutospore, 1/12. 
Parasitic Fungi of New Jersey

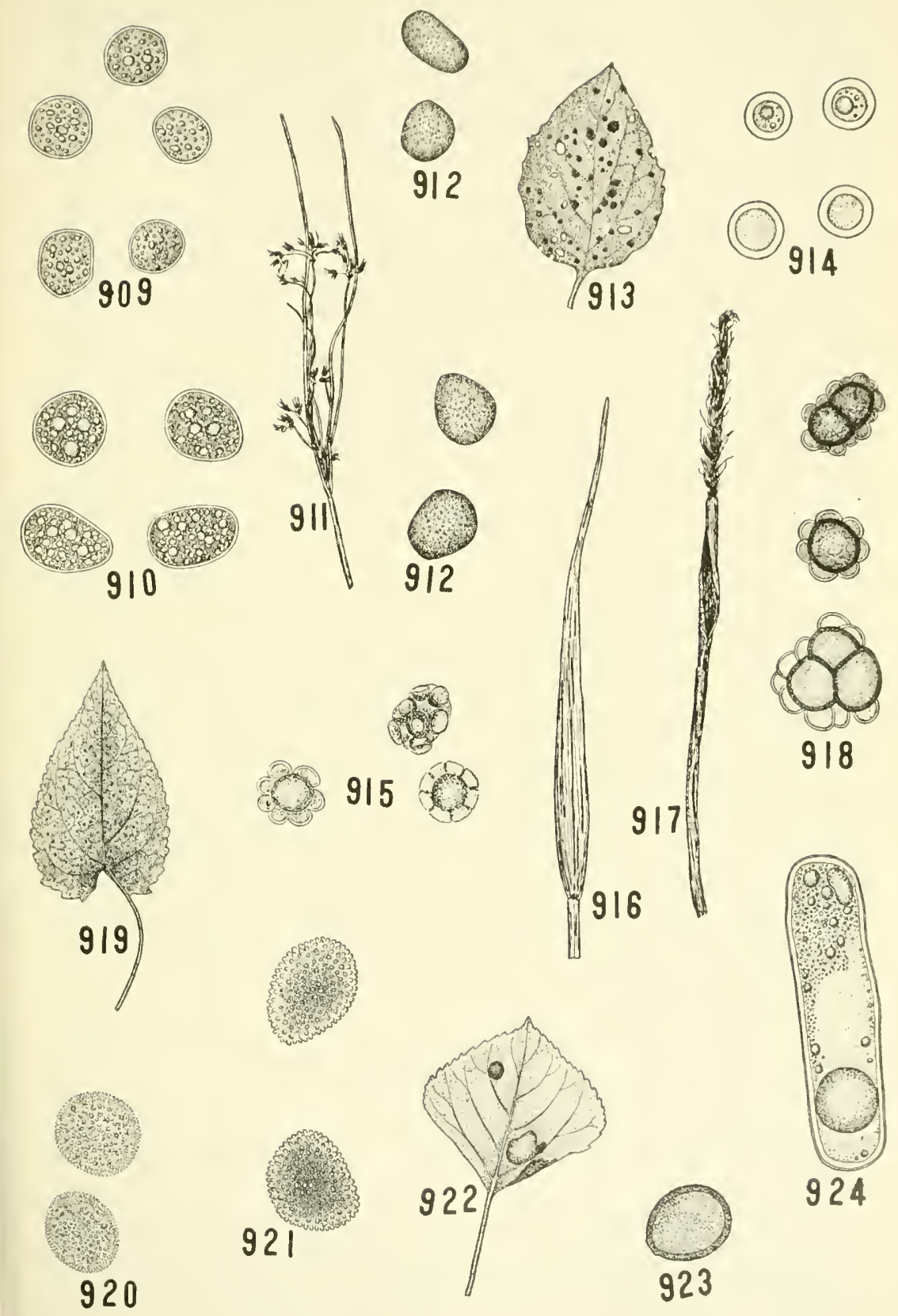


Coleosporium solidaginis (Schw.) Thüm. (= Peridermium acicolum Underw. \& Earle).

"O. Pycnia amphigenous, scattered, numerous, originating between mesophyl and cortical layer, noticeable, 0.3-0.5 mm. wide by 0.5-0.8 mm. long, dehiscent by a longitudinal slit, low-conoidal, 8-100 $\mu$ high.

"I. Aecia from a limited mycelium, amphigenous, numerous scattered on discolored spots occupying a part of a leaf, erumpent from longitudinal slits, tongue-shaped, 0.5-1 mm. long, by 0.50 .7 $\mathrm{mm}$. high; peridium rupturing irregularly, moderately firm, white, cells over-lapping, 35-45 $\mu$ long, not much narrower, walls transversely striate, inner coarsely verrucose, thick, 5-6 $\mu$, outer less rough and somewhat thinner æciospores ellipsoid, $20-25$ by $28-40 \mu$; wall colorless, closely and coarsely verrucose with deciduous tubercles which are directed away from a smooth spot extending up one side, thick, $2-3 \mu$ on the smooth spot, increasing to $5-6 \mu$ on the opposite side, including the tubercles.

"II. Uredinia hypophyllous, rarely also epiphyllous, irregularly scattered, or at first somewhat gregarious and crowded, 0.3-0.5 $\mathrm{mm}$. across, soon naked, yellow or orange-yellow, ruptured epidermis inconspicuous; urediniospores ellipsoid or globoid, $17-22$ by $20-30 \mu$; wall rather thin, $1-2 \mu$, closely and strongly verrucose; contents orange-yellow when fresh, fading to colorless." (On Pinus rigida.)

"III. Telia hypophyllous, scattered irregularly or sometimes crowded and confluent, slightly elevated, 0.3-0.5 mm., across, reddish-orange; teliospores with wall swelling $30-40 \mu$ thick above; contents orange-yellow fading to colorless, terete, $15-23$ by $55-80 \mu$, rounded or obtuse at both ends: basidiospores globoid or elliptical, about 12 by $18 \mu$, orange-yellow." (On Solidago sp.) North American Flora, v. 7, p. 90.

925. Infected pine needles showing æcia. 926. Cross-scction of pine needle showing æcia, 2/3. 927. Peridial cells, 1/12. 928. Aeciospores, 1/12. 929. Uredospores from leaf of cultivated aster, 1/12.

Cronartium comptonise Arthur ( = Periderminm pyriforme Peck.).

"O. Pycnia unknown.

"I. Aecia appearing on the branches or often on the trunks, with no or only slight fusiform enlargements, scattered and usually distinct, oval or irregular in outline, sometimes elongate $1-3$ by $1-6 \mathrm{~mm}$. or large by becoming confluent, peridium not much exserted above 
the roughened bark, rupturing along the sides and falling avay; æciospores pyriform, oblong-pyriform, or obovate, 19-24 x 32-66 $\mu$, usually acuminate below; wall $2-3 \mu$ thick, rather fincly and closely verrucose with low papillæ, contents orange-yellow when fresh." Mycologia, v. 6, p. 126-129 (1914). On Pinus rigida.

"II. Uredinia hypophyllous, scattered or somewhat gregarious, round, very small, about $0.1 \mathrm{~mm}$. across, dehiscent by a central rupture, soon wide open and naked, pulverulent; peridium rather firm, cells polygonal, at the sides with walls uniformaly thin about $1 \mu$ at the top with the inner walls greatly thickened, up to $10 \mu$; urediniospores oval or obovate, $16-21$ by $23-31 \mu$; wall colorless, rather thick, 2.5, sparsely and finely echinulate.

"Ill. Telial columns hypophyllous, filiform, 40-100 $\mu$ thick, 0.5-2 $\mathrm{mm}$. long; teliospores fusiform-oblong, 13-17 by 28-56 $\mu$, obtuse at both ends; walls nearly colorless, smooth, thin, 1-1.5 $\mu$. (On Comptonia sp.). North American Flora, v. 7, p. 121 (1907).

930. Peridial cells, 1/12. 931. Aeciospores, 1/12. 932. Uredospores, 1/12. 933. Teléutospore, $1 / 12$.

Cronartium ribicola Fisch. (= Periderminm strobi Kleb.).

"O. Pycnia caulicolous, scattered, honey-yellow, forming minute bladdery swellings, exuding a sweet fluid.

Aecia caulicolous, forming globose galls; peridium inflated, rupturing at sides, thick, membranous, cells isodiametric, smooth or nearly so on outer surface, verrucose on inner surface except an elongate smooth spot, 2-2.5 $\mu$ thick, on the smooth side 3-3.5 $\mu$ thick. (On Pinus strobus.)

"II. Uredinia hypophyllous, thickly scattered in orbicular groups 1-5 mm. across, round pustular, small, 0.1-0.3 mm. across, dehiscent by a central opening, at first bright yellow; peridia delicate, inner walls thicker than the outer walls; urediniospores ellipsoid or obovate, 14-22 by 19-35 $\mu$; wall colorless, medium thick, 2-3 $\mu$, sparsely and sharply echinulate."

"III. Telia columns hypophyllous, cylindrical, 125-150 $\mu$ thick, up to $2 \mathrm{~mm}$. long, curved, light orange-yellow becoming brownish; teliospores oblong or cylindrical, $8-12$ by $30-60 \mu$ rounded or obtuse at both ends; wall nearly colorless, smooth, rather thick, $2-3 \mu$. (On Ribes sp.) North American Flora, v. 7, p. 122 (1907).

934. Uredospores, 1/12. 935. Teleutospores, 1/12. 936. Portion of leaf of currant showing three uredo sori and four teleutosporic columns, $2 / 3$. 
Peridermium rostrupi E. Fischer (= Coleosporium campanule (Pers.) Lev. (See page 159.)

Polythelis thalictri (Chev.) Arthur. -On Thalictrum sp.

"O. Pycnia hypophyllous, few, sparingly scattered, among the telia, papillose, chestnut-brown, subcuticular, depressed-hemispherical, $110-130 \mu$ broad.

"III. Telia hypophyllous, evenly scattered, over large areas, never confluent, round 0.2-0.6 mm. across, dehiscent by a pore, early naked, pulverulent, dark, chestnut-brown, ruptured epidermis evident; teliospores ellipsoid or oblong-ovate, $17-26$ by $26-52 \mu$, greatly constricted at septum, the two cells easily separating, upper cell globoid, or rarely elliptical, the lower globoid, obvate or broadly cuneate, 16-26 by $18-26 \mu$; wall dark chestnut-brown, uniformly thick, $2 \mu$, coarsely and evenly verrucose; pedicel delicate, colorless, as long as the spore, wholly or partially deciduous. Mesospores usually plentiful." North American Flora, v. 7, p. 153 (1907).

937. Lower surface of infected leaf of Thalictrum sp. showing teleuto sori. 938. Teleutospores, 1/12.

Phragmidiual americanuar Dietel.-On Rosa sp.

"O. Pycnia chiefly epiphyllous, usually few, gregarious and often confluent, inconspicuous, subcuticular and extending downward between the cells, pale honey-yellow, low-conoidal or discoidal, 80-125 $\mu$ broad by $30-40 \mu$ high.

"I. Aecia chiefly hypophyllous or petiolicolous, usually compound or confluent, forming sori of irregular outline, $1-5 \mathrm{~mm}$. across, applanate bright orange-yellow fading to pale yellow ruptured epidermis usually noticeable; paraphyses rather numerous but inconspicuous, surrounding each individual sorus, erect; not exceeding the height of the spore mass, clavate, $10-20$ by $38-50 \mu$, the wall erenly thin, $1 \mu$, nearly or quite colorless, smooth; æciospores broadly ellipsoid or globoid, small, $18-20$ by $20-26 \mu$; wall paleyellow, rather thin, 1-1.5 $\mu$, finely and closely verrucose with wellseparated papillæ.

"II. Uredinia hypophyllous, numerous, thickly scattered, round, small. $0.1 \mathrm{~mm}$. or less across, early naked, ruptured epidermis inconspicuous; paraphyses encircling the sorus, abundant and conspicuous, strongly incurved, cylindrical or somewhat clavate, 9-13 by $30-55 \mu$, the wall evenly thin, $1 \mu$ or less, nearly or quite coloriess, smooth; urediniospores obovate-globoid, small, 15-18 by 18-20 $\mu$; wall pale yellow, thin, $1 \mu$, rather closely verrucose-echinulate, the pores indistinct, small, scattered, $8 \mu$ or more." 

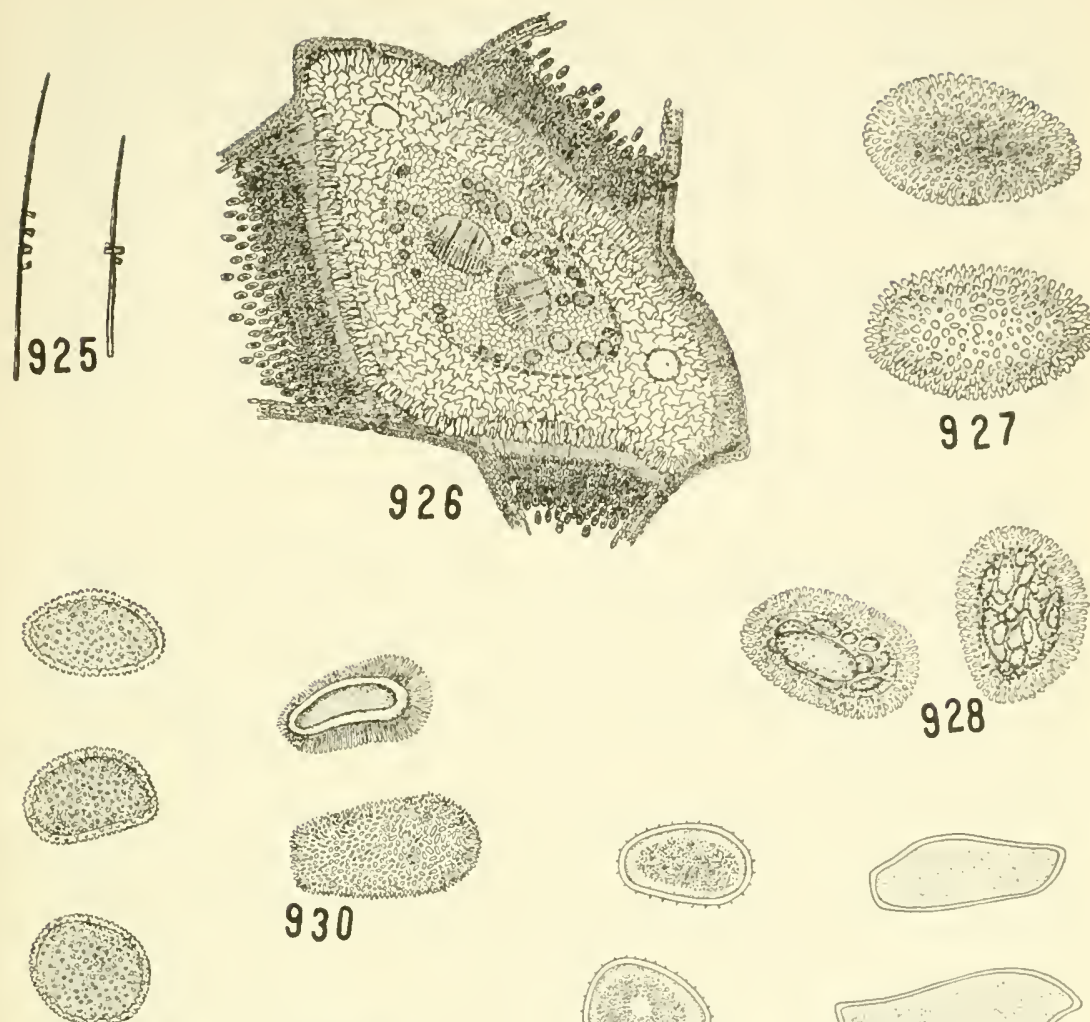

929
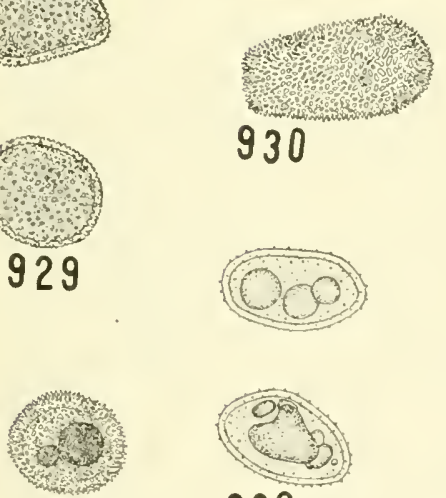

930
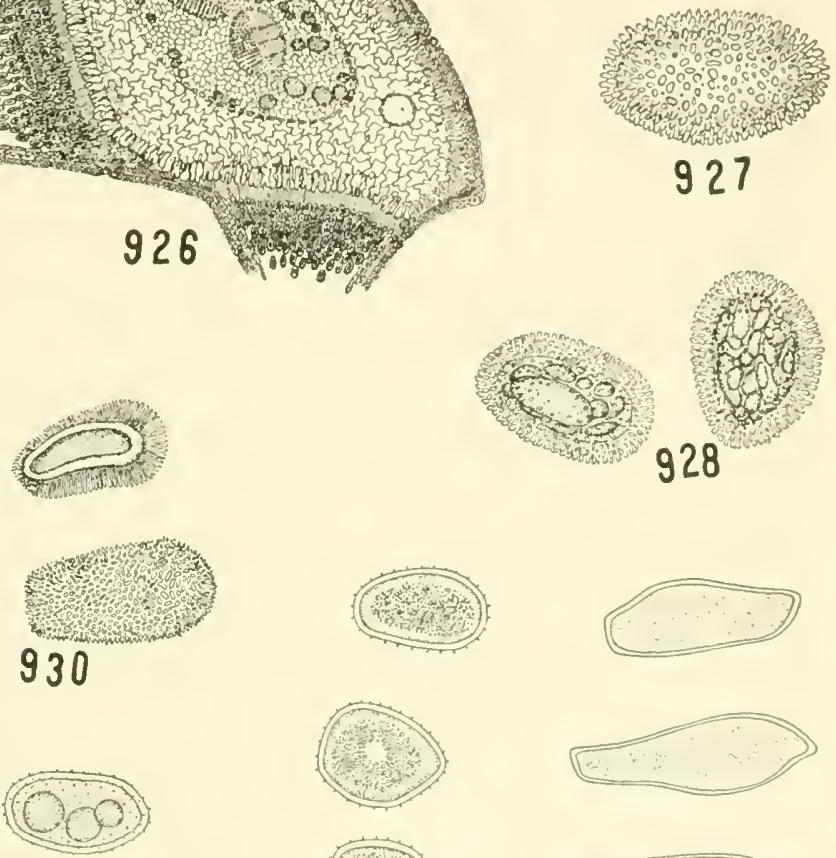

927

928
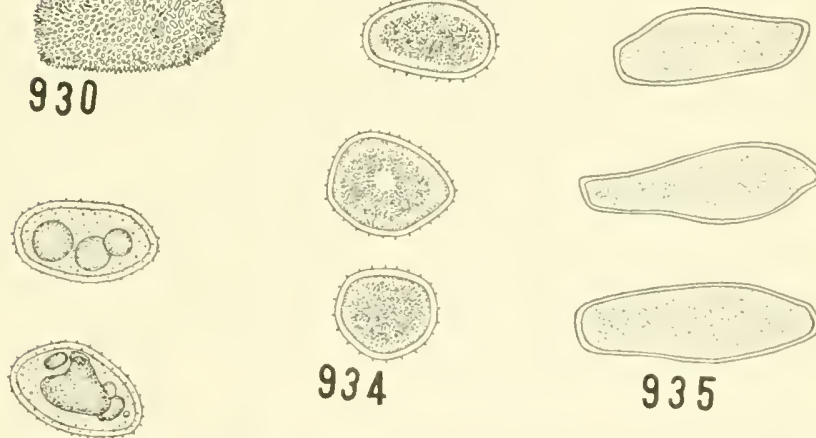

932
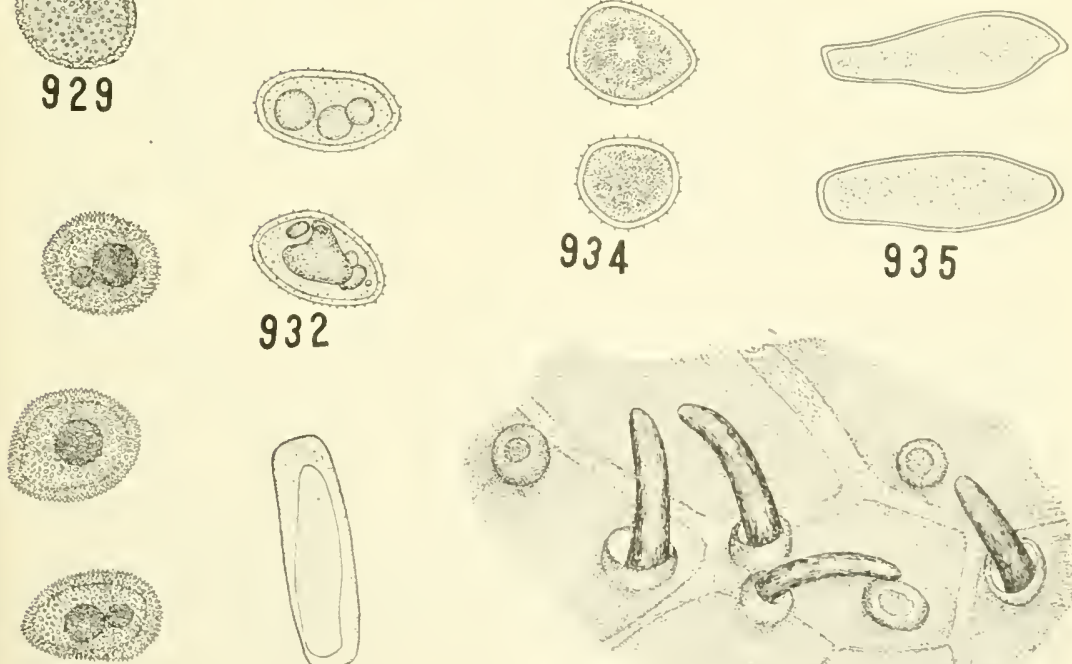

931

933

936 
"III. Telia hypophyllous, at first arising from the uredinia, numerous, thickly scattered, small, $0.1 \mathrm{~mm}$. or less across, few spores in each sorus, ruptured epidermis inconspicuous; paraphyses none; teliospores cylindrical, 23-26 by 64-100 $\mu$, slightly or not narrowed above or below, 8-11 (mostly 10) celled; wall blackish-brown, 3-7 $\mu$ thick, closely and rather coarsely verrucose, the apex usually with a conical hyaline papilla 10-12 $\mu$ long; pedicel rugose when dry, one and a half length of spore, the upper half colorless, except near the spore, $7 \mu$ in diameter, the lower part colorless, usually terete, swelling in water, 16-20 $\mu$ in diameter. North American Flora, v. 7, p. 167 (1912).

939. Teleutospore, 1/12.

Phragmidium obtusa (Strass.) Arthur.-On Potentilla canadensis. Described by Arthur as follows:

"O. Pycnia epiphyllous, in small crowded groups 0.1-.4 $\mathrm{mm}$. across, on slightly larger reddened and somewhat hypertrophied spots, inconspicuous, in section globoid-lenticular 112-160 $\mu$ broad by $35-50 \mu$ high.

"II. Uredinia at first epiphyllous, surrounding the pycnia, in crowded groups 0.5-1.3 mm. across, roundish or irregular, often confluent into rings, at first bullate, soon naked, somewhat waxy; uredinia afterward hypophyllous, scattered irregularly, round, 0.2-0.5 mm. across, early naked, slightly pulvinate, pulverulent, orangeyellow, fading to dirty-white, ruptured epidermis noticeable; paraphyses usually wanting; uredinospores obovate or ellipsoid, 15-18 by $19-26 \mu$; wall pale-yellow, nearly colorless, thin, $1-1.5 \mu$, finely verrucose-echinulate, points, 1-2 $\mu$ apart, the pores small, inconspicuous, 3 or 4 , equatorial.

III. Telia hypophyllous, scattered, round, 0.2-0.5 mm. across, early naked. pulvinate. velvety, cinnamon-brown, ruptured epidermis inconspicuous: teliospores cylindrical-clavate, or clavate-lanceolate, 20-27 by $48-90 \mu$, rounded or obtuse above, obtuse or narrowed below, slightly or not constricted at the septa, 3-5 celled; wall cinnamon-brown, paler below, thin, 1-2 $\mu$, thicker at apex, 5-8 $\mu$; smooth; pedicel colorless, or tinted next to the spore, terete, 7-10 $\mu$ in diameter, firm, with thick wall, one half to once length of spore."

Note. In North Amercan Flora as Kuehneola obtusa, v. 7, p. 185 (1912).

940. Uredospores, 1/12. 941. Teleutospores, 1/12. 
Earlea speciosa (Fries) Arth.--On leaves of cultivated roses.

"O. Pycnia chichly epiphyllous and caulicolous, crowded in considerable groups, often confluent, inconspicuous, subcuticular, extending well into the lateral walls of the epidermal cells, pale honeyyellow, flattened-conoidal or discoidal, $65-160 \mu$ in diameter by $35-50 \mathrm{~mm}$. high.

"I. Aecia hypophyllous and caulicolous, usually on swollen and distorted areas of more or less cxtent, roundish, $0.5-1 \mathrm{~mm}$. across, on leaves forming small groups, on petioles, stems and fruit confluent into irregular groups $10 \mathrm{~mm}$. or more long, applanate, bright crange fading into palc yellow, ruptured epidermis usually conspicuous; paraphyses at first often rudimentary or wanting, in senile sori. peripheral, usually few, erect, finally somewhat exceeding the height of the spore mass, slender, clavate or cylindrical, 9-13 by $42-50 \mu$, the wall almost evenly thin $1 \mu$ or less, colorless; æciospores oblongelliptical, obovate, rarely oblong-clavate, $16-24 \times 24-35 \mu$; wall paleyellow, rather thin, 1-2 $\mu$, distinctly echinulate-verrucose with pointed beads standing $1 \mu$ apart, the pores indistinct, scattered.

"III. Telia caulicolous, gregarious, crowded, oblong, about $1 \mathrm{~mm}$. long, usually more or less confluent and 10-30 mm. long causing a somewhat fusiform hypertrophy, at first crust-like, with age becoming felty, grayish-black; teliospores cylindrical, $21-27$ by $58-102 \mu$, rounded at both ends, except a semi-hyaline apiculus above 3-7 $\mu$, long and nearly as broad, $4-8$ celled; walls smoky-brown, $3-5 \mu$ thıck, smooth, the pores 2 or sometimes 3 in each cell; pedicel three to five times length of spore, slightly tinted especially near the spore, 7-9 $\mu$ in diameter, usually tapering in lower part, nearly or quite solid due to thickened walls, somewhat rugose near base." North American Flora, v. 7, p. 175 (1912).

942. Teleutospore from cultivated rose, $1 / 12$.

Kuehneola uredinis (Link) Arthur.-On species of Rubus sp. "O. Pycnia epiphyllous, in small crowded groups $0.3-0.5 \mathrm{~mm}$. across, on somewhat larger reddened spots, pustular, prominent, flattened-hemispherical, or irregularly lenticular, large, 150-200 $\mu$ in diameter, nearly half as high.

"II. Uredinia at first epiphyllous, surrounding the pycnia, in crowded groups $0.5-1.3 \mathrm{~mm}$. across, irregular in outline, 0.1-0.3 mm. across, in shortest diameter, usually somewhat elongate and often confluent into rings, at first bullate, soon naked and applanate, pulverulent, orange-colored fading to whitish, ruptured epidermis noticeable; uredinia afterward hypophyllous, scattered irregularly, 
round, small, about $0.1 \mathrm{~mm}$. across, early naked, pulverulent, pale lemon-yellow becoming nearly colorless, ruptured epidermis inconspicuous; paraphyses wanting; urediniospores of primary form irregularly ellipsoid or elliptical obovate, $16-20$ by $20-27 \mu$, of secondary form more regularly-obovate, or globose-obovate, and slightly smaller, $15-19$ by $17-25 \mu$; wall nearly or quite colorless, moderately thin, about $1.5 \mu$, noticeably and rather closely verrucose-echinulate, points about $1 \mu$ apart, lower and broader in the primary than in the secondary form, the pores small, very indistinct, probably 3 or 4 and equatorial.

"III. Telia hypophyllous, irregularly scattered, irregularly roundish, 0.1-0.5 mm. across, early naked, pulvinate, velvety, yellowish or pure white, ruptured epidermis inconspicuous; teliospores cylindrical or cylindrical-clavate, $18-24$ by $85-110 \mu$, irregularly flattened or coronate above, narrowed below, 5-13 celled usually 5-6 celled, each cell 15-24 by 17-40 $\mu$, mostly 20-25 $\mu$, trapezoidal and articulated to the cell above by a projection at one side containing the pore; wall nearly or quite colorless, thin, 1.5-2 $\mu$, the apical cell thicker above, 3-5 $\mu$, the other cells thickened above uniformly or only at the lateral projections, smooth or slightly roughened at apex; pedicel colorless, terete, very short, often seemingly wanting." North American Flora, v. 7, p. 186 (1912).

\section{Infected cane of blackberry. 944. Uredospores $1 / 12$.}

Gymnosporangium botryapites (Schw.) Kern.-On Chamacyparis thyoides.

"O. Pycnia epiphyllous, few gregarious, in small groups, 0.7-1.5 $\mathrm{mm}$. across, punctiform, honey-yellow becoming hlackish, conical, 128-190 $\mu$ in diameter by 64-112 $\mu$ high; ostiolar filaments, 30-65 $\mu$ long.

"I. Aecia hypophyllous, few, usually aggregated in groups of 2-8, rarely solitary, borne in gall-like, pyriform protuberances $1-1.5 \mathrm{~mm}$. in diameter by $64-112 \mu$ high by $1.5-3 \mathrm{~mm}$, cylindrical, $0.3-0.8 \mathrm{~mm}$. in diameter by 2-4 mm. high; peridium soon becoming finely cancellate, not dehiscent at apex; peridial cells cylindrical, long and narrow, hypha-like, 9-14 $\mu$ in diameter by 145-190 $\mu$ long, often irregularly bent, the outer, inner, and side walls of equal thickness, about 1.5-2 $\mu$, whole surface smooth; æciospores globoid, small, 15-17 by $16-22 \mu$; wall dark cinnamon-brown, $2.5-3 \mu$ thick, moderately verrucose, the pores obscure, numerous, scattered." North American Flora, v. 7, p. 195 (1912). On Amelanchier canadensis. 


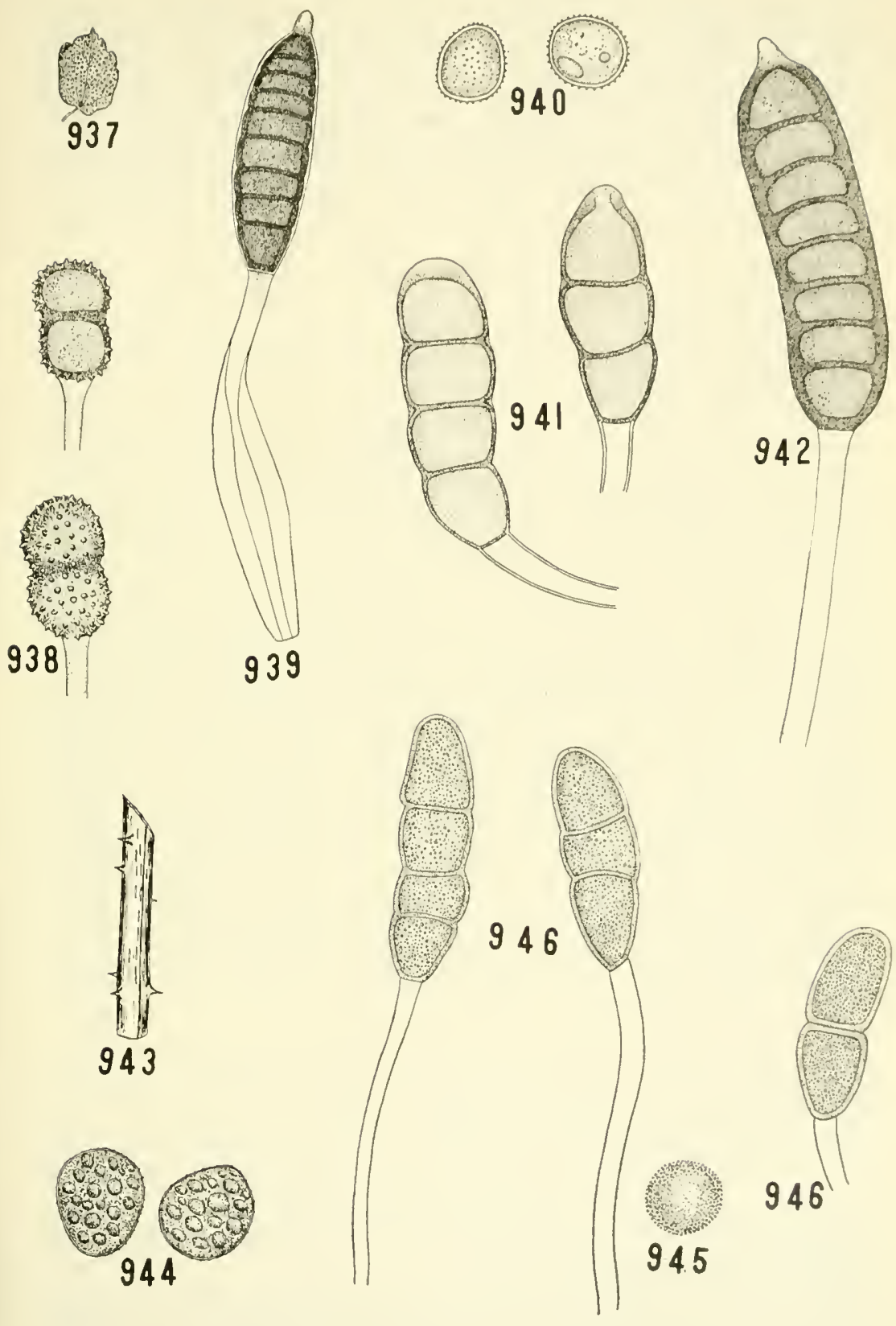


"Telia caulicolous, appearing on fusiform swellings, scattered, oval or irregular, about 1.5-3 mm. wide, by $2-7 \mathrm{~mm}$. long, often confluent, hemispheric, chestnut brown; teliospores 2-4 celled, 13-19 $\mathrm{x}$ 35-77 $\mu$, usually rounded above, somewhat narrowed below, slightly constricted at the septa, wall pale yellow, $1-1.5 \mu$, the pores 2 in each cell, near the speta." Kern in Bul. N. Y. Bot. Garden, v. 7, p. 452.

945. Aeciospores from Amelanchier sp., 1/12. 946. Teleutospores from Chamæcyparis thyoides, $1 / 12$.

Gymmosporangium effusum Kern.-On Juniperus virginiana.

"O. Ecia unknown.

"III. Telia caulicolous, from a perennial mycelium, usually appearing on branches $0.3-1.5 \mathrm{~cm}$. in diameter, causing long slender fusiform enlargements $0.5-2.5 \times 15-40 \mathrm{~cm}$., extending into and causing some swelling of the smaller branches and twigs arising from the infected areas, sometimes on the larger trunks, usually breaking forth in series along the branch with the grain of the wood, unevenly disposed, hypertrophied scars of previous seasons frequently interspersed, when dry more or less wedge-shaped, but often irregular and lacunose, sometimes forked or divided and staghornlike, when mature and expanded $2-3 \mathrm{~mm}$. broad by $2-5 \mathrm{~mm}$. long at base, $7-10 \mathrm{~mm}$. high, the surface morc or less rugose, dark chestnutbrown becoming cinnamon-brown after expansion; teliospores 2-celled, oblong-ellipsoid, 16-22 by 45-55 $\mu$, rounded or slightly narrowed both above and below, slightly constricted at the septum; wall dark cinnamon brown, rather thin, 1-2 $\mu$, varying in thickness on different spores, the pores 1 or 2 in each cell, near the septum; pedicel hyaline, cylindrical, uniform, 3-5 $\mu$ in diameter, very long." North American Flora, v. 7, p. 201 (1912).

947. Teleutospores from Juniperus virginianc, 1/12.

Gymnosporangium ellisil (Berk|) Farlow.-On Chamacyparis thyoides. This has been described by Fromme as follows:

"O. Pycnia epiphyllous, gregarious, in crowded circular groups, 2-5 mm. in diameter, on blackened areas, subepidermal, orange-yellow, globose in vertical section, $140-190 \mu$ broad by $175 \mu$ deep; ostiolar filaments $30-80 \mu$ long.

"I. Aecia hypophyllous, fructicolous and caulicolous, in crowded groups, on discolored hypertrophied areas, cupulate, $0.2-0.3 \mathrm{~mm}$. in diameter; peridium yellowish, fragile, becoming lacerate to the base, 
slightly recurved, peridial cells oblong, 26-29 by 32-39 $\mu$, overlapping, the outer wall thick, 7-10 $\mu$, smooth, transversely striate, the inner wall much thinner, $2-3 \mu$, closely and prominently verrucose; æciospores globoid to oblong, 24-30 by $27-34 \mu$, the wall pale-yellow or colorless, $2-3 \mu$ thick, closely and strongly verrucose, the pores 6-8, scattered." Mycologia, v. 6, p. 229 (1914). On Myrica sp.

"Telia caulicolous, from a perennial mycelium which distorts the younger branches causing slight enlargements and usually dense fasciations, numerous, thickly scattered, often over considerable areas, cylindric, filiform, 3-6 mm. long, about 0.5-1 mm. in diameter, orange colored; teliospores 2-5 celled, linear, fusiform, 9-16 x 85$170 \mu$, not constricted at the septa, wall pale yellow, thin, about $1 \mu$, pores 2 in each cell ( 1 in the uppermost), apical." Kern in Bul. N. Y. Bot. Garden, v. 7, p. 466, 467 (1911).

948. Myrica carolinensis showing rcia. 949. Peridial cells, 1/12. 950. Aeciospores, 1/12. 951. Teleutospore, 1/12, from Chancacyparis thyoides.

Gymnosporangium fraternum Kern.-On Chamacyparis thyoides.

"O. Pycnia and æcia unknown.

"III. Telia foliicolous, from an annual mycelium, solitary, scattered, oval, 0.8-2 mm. across, pulvinate, chestnut-brown, ruptured epidermis usually noticeable; tcliospore 2-celled, ellipsoid, 16-19 by $39-48 \mu$, rounded above, narrowed below, slightly constricted at the septum; wall cinnamon-brown, moderately thin, 1.5-2.5 $\mu$, thicker above, $3-5 \mu$, the pores two in each cell, near the septum; pedicels cylindrical, uniform, 5-6 in diameter." North American Flora, v. 7, p. 191 (1912).

952. Teleutospores, 1/12, from Chamacyparis thyoides.

Gymnosporangium JUniperi-virginian ex Schw.-On Juniperus virginiana.

“O. Pycnia epiphyllous, numerous, gregarious, more or less crowded in irregular groups, $1-5 \mathrm{~mm}$. across, on discolored spots 5-15 mm. across, prominent, conspicuous, punctiform, honey-ycllow becoming blackish, globoid, 110-125 $\mu$ in diameter by 110-130 $\mu$ high ; ostiolar filaments $35-50 \mu$ long.

"I. Aecia chiefly hypophyllous, crowded in annular groups 1.5-10 $\mathrm{mm}$. across, on thickened discolored spots $5-15 \mathrm{~mm}$. across, at first cylindrical, 1-2 mm. high, 0.1-0.4 $\mathrm{mm}$. in diameter, peridium splitting extremely early and becoming very finely fimbriate to the base, strongly revolute; peridial cells usually seen only in side view, long and narrow, $10-16$ by $65-100 \mu$; hygroscopic, becoming strongly 
curved, when wet, the outer wall moderately thin, 2.5-3 $\mu$, smooth, the inner, wall coarsely rugose, moderately thick, 4-6 $\mu$, the side walls rather sparsely rugose with ridges running from the inner side obliquely downward, extending about half-way across or more and becoming gradually broader, with shorter ridge-like papillæ in the intervening spaces; æciospores globoid or broadly ellipsoid, 16-24 by 21-31 $\mu$; wall light chestnut-brown, moderately thick, 2-3 $\mu$, finely verrucose, the pores distinct, $8-10$ scattered. On various species of malus.

"III. Telia foliicolous, from an annular or biennial mycelium, appearing on globoid or reniform gall-like excrescences 5-30 mm. or more in diameter, rather evenly disposed, about $1.5-4 \mathrm{~mm}$. apart, cylindrical or cylindrical-acuminate, becoming about $1.5-3 \mathrm{~mm}$. in diameter by 10-20 mm. long when fully mature, golden-brown, becoming yellowish and pulverulent by germination, the ruptured tegumentary tissues raised about the base of the sori in an even ringlike manner; teliospores 2-celled, rhombic-oval or narrowly ellipsoid, $15-21$ by $42-65 \mu$, obtuse or acute at both ends, slightly or not constricted at the septum; wall pale cinnamon-brown, uniformly thin, about $1 \mu$, the pores 2 in each cell, near the septum; pedicel hyaline, cylindrical, uniform, 3-5 $\mu$ in diameter, very long." North American Flora, v. 7, p. 209 (1912).

953. Aecidium from apple leaf, 2/3. 954. Peridial cell, 1/12. 955. Aeciospores, 1/12. 956. Teleutospores from Juniperus virginiana.

Grarosporangium germinale (Schw.) Kern.-On Juniperus sp.

"O. Pycnia chiefly fructicolous, gregarious, in irregular groups, on slightly hypertrophied areas occupying part or all of the surface, prominent, conspicuous, honey-yellow becoming blackish, slightly tlattened-globose, large $160-270 \mu$ in diameter by $150-230 \mu$ high; ustiolar filaments $90-150 \mu$ long.

"I. Aecia fructicolous and caulicolous, crowded on hypertrophied areas of variable size on the twigs and peduncles, occupying part or usually all of the surface on the fruits, cylindric, 1.5-3 mm. high by $0.3-0 \mathrm{~mm}$. in diameter; peridium whitish, becoming coarsely lacerate sometimes to base, erect or spreading peridial cells seen in both face and side views, not hygroscopic, remaining straight when wet, polygonal-ovate or polygonal-oblong in face view, 19-39 by 45-95 $\mu$, rhomboidal in side view, $25-40 \mu$ thick, the outer wall moderately thick, $3-5 \mu$, smooth, the inner wall very thick 13-23 $\mu$, coarsely verrucose with rather loosely set, large, very irregularly branched papillæ, the side walls verrucose on the inner 


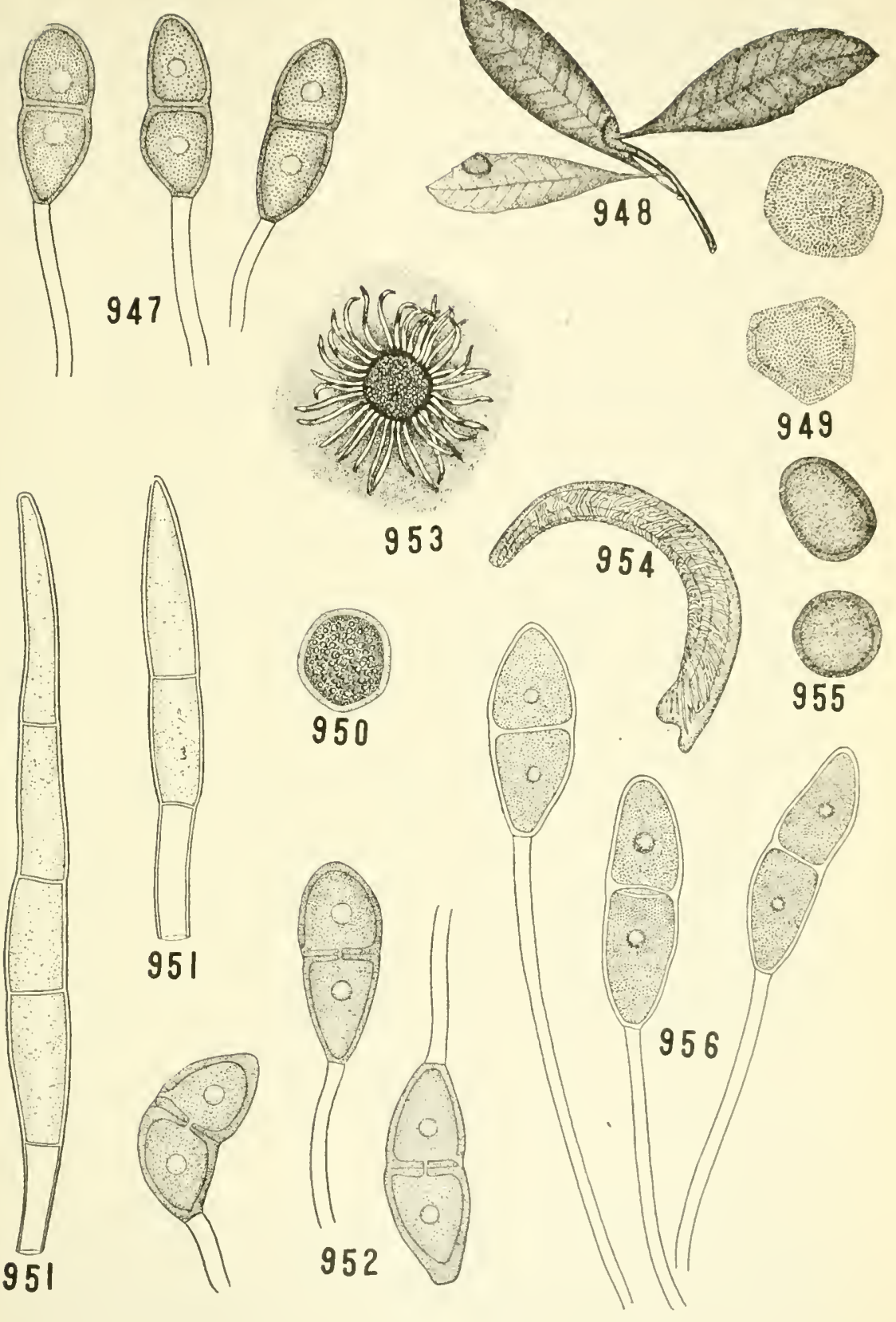


half similar to the inner wall; æciospores globoid, large, 21-32 by 24-39 $\mu$; wall pale yellow, thick, $3-4.5 \mu$, rather coarsely verrucose with crowded, slightly irregular papillæ, sometimes appearing reticulate, the pores 6-10, scattered, very obscure. On Cydonia vulgaris and Crategus sp.

"III. Telia caulicolous, from a perennial mycelium, appearing on slight fusiform swellings, usually aggregated, roundish, 1-4 mm. across, often confluent, hemispherical, 1-3 mm. high, orange-brown; teliospores 2-celled, ellipsoid, $18-26$ by $35-51 \mu$, roundish or somewhat acutish above, obtuse below, slightly or not constricted at the septum; wall yellowish, thin, 1-2 $\mu$, slightly thicker at apex, 2-3 $\mu$, the pores 1 in each cell, apical in the upper, near the pedicel in the lower cell; pedicel in the lower cell; pedicels carotiform, 9-19 $\mu$ in diameter near the spore, very long." North American Flora, v. 7, p. 197 (1912).

957. Distorted twig of Cratagus sp. showing æcia. 958. Peridial cells, 1/12. 959. Aeciospores, 1/12. 960. Teleutospores, 1/12.

Gymnosporangium globosum Farl.-On Juniperus virginiana.

"O. Pycnia epiphyllous, numerous, gregarious, more or less crowded in irregular groups 1-3 mm. across, on discolored spots 3-7 mm. across, prominent, conspicuous, honey-yellow becoming blackish, slightly flattened, globose, $150-190 \mu$ in diameter by $115-175 \mu$ high; ostiolar filaments $65-80 \mu$ long.

"I. Aecia chiefly hypophyllous, crowded in irregular annular groups, 2-7 mm. across, on thickened, discolored spots $3-12 \mathrm{~mm}$. across, cylindrical, 1.5-3 mm. high by 0.1-0.2 $\mathrm{mm}$. in diameter; peridium soon splitting in the upper part, becoming reticulose half way to the base, the margin finely lacerate or fimbriate, erect; peridial cells seen in both face and side views, not hygroscopic, remaining straight when wet broadly lanceolate in face view, $15-23$ by $60-90 \mu$; linear-rhomboidal in side vicw, $13-19 \mu$ thick, the outer wall rather thin, about $1.5 \mu$, smooth, the inner and side walls moderately thick, $3-5 \mu$, rather densely rugose with ridges of varying length; æciospores globoid or broadly ellipsoid, $15-19$ by $18-25 \mu$; wall light chestnut-brown, 1.5-2 $\mu$ thick, finely verrucose, the pores distinct, 6-8. scattered." On Malus sp.

"Telia caulicolous, from a perennial mycelium, appearing on irregular globoid gall-like excrescences $3-25 \mathrm{~mm}$. in diameter, unevenly disposed, sometimes densely aggregate, often separated by the scars of the sori of previous seasons, tongue- or wedge-shaped, becoming about $1.5-3 \mathrm{~mm}$. broad by $2-5 \mathrm{~mm}$. long at the base by $6-12 \mathrm{~mm}$. 
high when fully mature, chestnut-brown becoming yellowish and pulverulent by germination; teliospores 2-celled, ellipsoid, 16-21 by $37-48 \mu$, somewhat narrowed above and below, slightly constricted at the septum, wall pale cinnamon-brown, uniformly thin, $1-2 \mu$, the pores 2 in each cell, near the septum; pedicel cylindrical, uniform, 4-7 $\mu$, in diameter, very long." North American Flora, v. 7, p. 204206 (1912).

961. Peridial cell, 1/12. 962. Aeciospores, 1/12. 963. Teleutospores, 1/12, from Juniperus virginiana.

Gymnosporangium transformans (Ellis.) Kern.-On Aronia arbutifolia and Amelanchier sp.

"O. Pycnia chiefly epiphyllous and fructicolous, gregarious, rather crowded in small groups $0.5-1 \mathrm{~mm}$ across, on discolored spots 2-7 mm. across, noticeable, honcy-ycllow becoming brownish, globoid, rather large, $144-170 \mu$ in diameter by $112-150 \mu$ high; ostiolar filaments $60-75 \mu$ long.

"I. Aecia hypophyllous, caulicolous, and fructicolous, occasionally solitary, usually gregarious, sometimes few together but more often aggregate in large groups, borne in gall-like, frustum-shaped protuberances (1-2 mm. high) of a reddish-brown color and nore or less consolidated at the bases in the groups, at first cylindrical, 2-2.5 mm. high by 0.2-0.4 mm. in diameter; peridium soon becoming finely fimbriate to base, partially dropping away, and narrow hygroscopic, becoming curved or even coiled when wet, $12-18 \mu$ thick by 150-300 $\mu$ long, or more, in the sides of the peridium, much shorter toward the apex, the outer wall rather thin, 2-3 $\mu$, smooth, the imer wall, 4-6 $\mu$ thick, rather coarsely verrucose, the side walls verrucose on inner half with roundish or somewhat irregular papillæ, more thickly crowded toward the inner side, the outer half of the side walls smooth; xciospores globose, small, $18-22 \mu$ in diameter; wall light cinnamon-brown, 1.5-2.5 $\mu$ thick, rather finely verrucose, the pores 6-S scattered." North American Flora, v. 7, p. 202 (1912).

III. Telia on leaves of Chamacyparis.

964. Leaves of Amelanchier showing æcia. 965. Peridial cell, 1/12. 966. Aeciospore, 1/12.

Uromyces appendiculatus (Pers.) Lév.-On beans.

"O. Pycnia epiphyllous, in small groups, rather large, papillose, honey-yellow, globoid, 100-125 $\mu$ in diameter.

"I. Ecia hypophyllus, in small often annular groups, 2-3 mm. across, short, cupulate, peridium white, margin spreading or some- 
what revolute, lacerate, peridial cells rhomboidal or linear rhomboidal, somewhat over-lapping, $10-13 \mu$, broad, by $24-30 \cdot \mu$ long, the outer wall moderately thick, 4-5 $\mu$, transversely striate, the inner wall thinner, $2-3 \mu$, verrucose, æciospores ellipsoid, $16-20$ by $20-26 \mu$, wall colorless, thin, 1-1.5 $\mu$, minutely and closely verrucose.

"II. Uredinia amphigenous, scattered, roundish, small about 0.5 mim. or less in diameter, soon naked, cinnamon-brown somewhat pulverulent, ruptured epidermis evident; urediniospores ellipsoid, obovoid, or subglobose, $16-23$ by $20-33 \mu$; wall light golden-brown, rather thin 1-1.5 $\mu$, sharply and sparsely echinulate, the pores 2 , rarely 3 , equatorial.

"III. Telia amphigenous, scattered, roundish, about 0.5 in diameter, early naked, blackish-brown, somewhat pulverulent, ruptured epidermis evident; teliospores broadly ellipsoid or subglobose, 20-26 by $24-32 \mu$, rounded or obtuse above, ustrally rounded below; wall dark chestnut-brown, rather thick, 3-3.5 $\mu$ with a large hemispherical hyaline apiculus above making the wall 6-10 $\mu$ thick, smooth or with a few small, sparsely scattered hyaline papillæ; pedicel, hyaline, about as long as the spore." In North American Flora, v. 7, p. 257 (1912) as Nigredo appendiculata.

967. Leaflet of bean showing uredo sori. 968. Uredospores, 1/12. 969. Leaflet showing teleuto sori. 970. Teleutospores, 1/12.

URomyces CARyophyllinus (Schrank) Winter.-On the leaves of the cultivated carnations. Described by McAlpine as follows:

"Uredosori amphigenous, dark brown when exposed, but long covered by epidermis, round or oblong, scattered, often confluent up to $3 \mathrm{~mm}$. long.

"Uredospores roundish or oblong, yellowish-brown to goldenbrown, decidedly echinulate, generally 3-4 scattered or nearly equatorial germ-spores on one face, 21-34 × 17-28 $\mu$, average $32 \times 24 \mu$.

"Teleutosori amphigenous, blackish-brown, oblong, confluent in elongated lines, long, covered by ashy epidermis, then margined by the ruptured and ragged cuticle.

"Teleutospores at first intermixed with uredospores, roundish, oval or ovate, cinnamon-brown, generally thickened, with broad colorless papilla, average $28 \times 20 \mu$ or $22-32 \times 17-23 \mu$; pedicels very deciduous, hyaline, up to $45 \mu$ long." McAlpine, Rusts of Australia, p. 102.

971. Portion of infected carnation showing sori on stem and leaves. 972. Cross-section of uredo sorus on leaf, 2/3. 973. Uredospore, 1/12. 974. Teleutospores, 1/12. 975. Intcrcellular mycelium and haustoria, 1/12. 

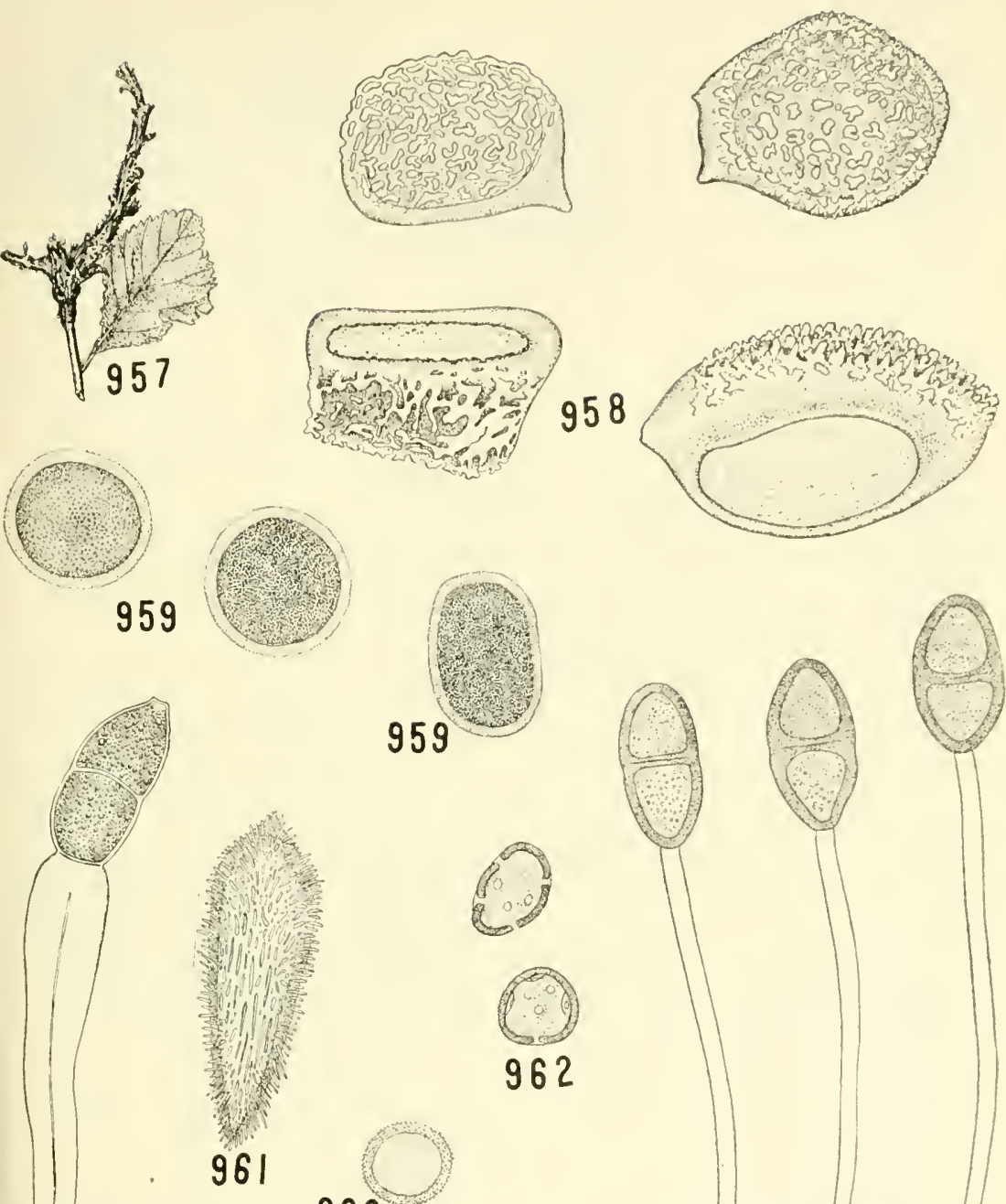

959
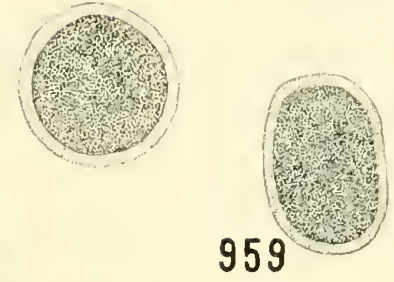

960
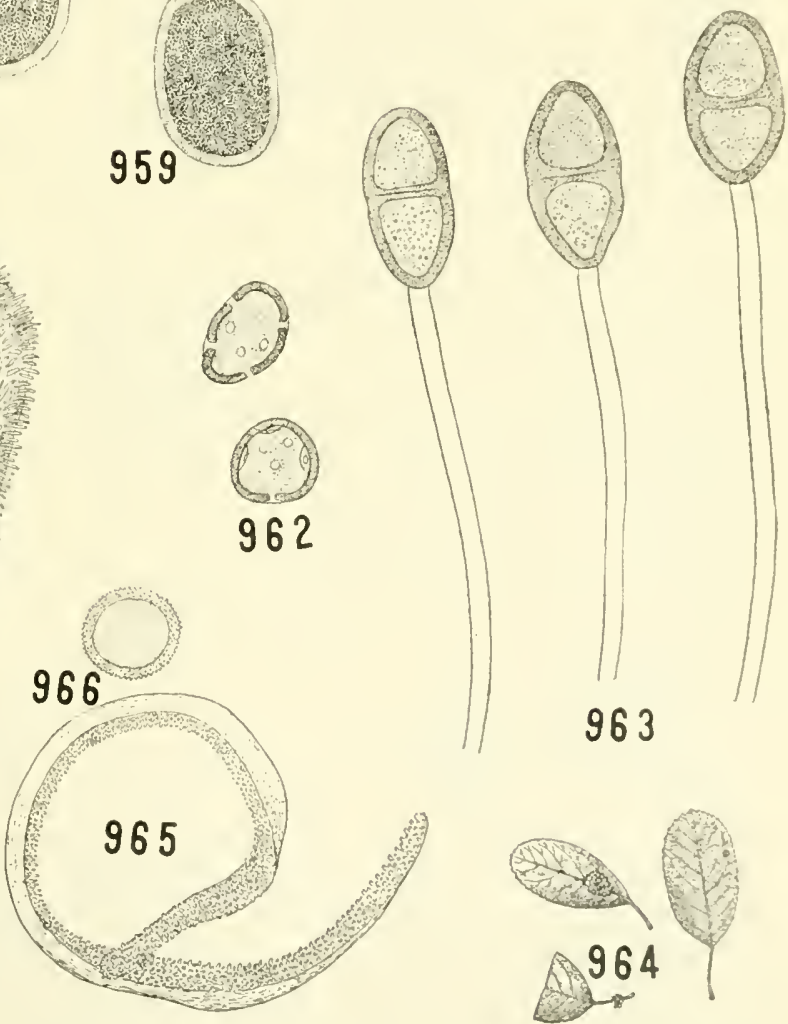
Uromires howei (Peck) Arth.-On Asclepias sp.

"O. Pycnia and æcia unknown.

"II. Uredinia hypophyllous, scattered, roundish, $0.5 \mathrm{~mm}$. across, early naked, pulverulent, cinnamon-brown, ruptured epidermis evident; urediniospores globoid, $18-25$ by $23-28 \mu$; wall golden brown, thin, $1-1.5 \mu$, evenly echinulate, the pores 4 , equatorial.

"III. Telia hypophyllous, thickly scattered, roundish, $0.5 \mathrm{~mm}$. across, early naked, pulverulent, light chestnut-brown, ruptured epidermis noticeable; teliospores broadly ellipsoid or globoid, 1S-23 by $20-30 \mu$, rounded or somewhat obtuse at both ends; wall chestnut brown, rather thin, $1.5 \mu$, slightly thicker above owing to presence of a small semi-hyaline papilla, finely and closely verrucose; pedicel colorless, fragile, short." In North American Flora, v. 7, p. 264 (1912) as Nigredo howei.

976. Uredospores, 1/12 from Asclepias sp. 977. Teleutospores, 1/12.

Puccinia Antirrhini Dietel \& Holw.-On cultivated snapdragon in greenhouses and in the garden. Producing on the average uredospore sori which are chestnut-colored, uredospores elliptical or globose, $23-30 \times 21-25 \mu$, chestnut-colored, minutely echinulate, germinating pores 2 rarely 3 ; teleutospore sori cushion-shaped, dark, on pale spots on foliage or scattered upon dry spots, amphigenous, particularly hypophyllous on the average or minutely irregularly scattered on large stems, surrounded by a split epidermis, confluent, teleutospores oblong or irregular, apices conical, rotund or truncate, bases attenuate, rarely rounded, at septa moderately constricted, epispore obscurely chestnut-colored or faintly dark, apices somewhat thickened, covering smooth, $36-50 \times 17 \times 26$ pedicel long. Hedwigia, v. 36, p. 298 (1897).

978. Infected leaves of Antirrhinum majus. 979. Uredospores, 1/12. 980. Infected stem of $A$. majils. 981. Teleutospores, 1/12.

Puccinia asparagi D. C.-On cultivated asparagus. Described by Holway as follows:

"O. Spermagonia yellow, clustered in the center of the groups of æcidia.

"I. Aecidia on the stems, scattered or collected in irregular, oblong groups, low margin incised not reflexed; æcidiospores yellow globose to polygonal, finely verrucose, $16-28 \mu$ in diameter.

"II. Uredosori cinnamon-brown, oblong, sometimes confluent up to $4 \mathrm{~mm}$. in length, surrounded by the ruptured epidermis; uredospores globose to ovate, minutely echinulate, 20-32 x 20-24 $\mu$; germpores 5 . 
"Teleutosori dark-brown, round to oblong or elliptical, often thickly covering the entire plant, pulvinate, firm; teleutospores chestnut-brown, smooth, elliptical to oblong, apex rounded, up to $8 \mu$ thick, lower cell mostly rounded, rarely narrowed to the pedicel, slightly constricted, $32-48 \times 18-24 \mu$; pedicel persistent, tinted, varying in the same sorus from short up to $80 \mu$ long.' Holway, C. IV. D.-North American Uredineæ, v. 1, p. 27 (1905).

982. Infected stem of asparagus. 983. Aeciospores, 1/12. 984. Uredospore, 1/12. 985. Teleutospores $1 / 12$.

Puccinia canaliculata (Schw.) Lagerh.-On Cyperus sp.

"O. Pycnia amphigenous in small, confluent groups, honey-yellow becoming brownish, subepidermal, globoid, small.

"I. Aecia hypophyllous, in circular or elongated groups, 0.3-0.8 mm. across, on discolored, unthickened spots, low cupulate, small, 0.2-0.3 $\mathrm{mm}$. in dianeter: peridium colorless, the margin finely eroded and slightly recurved; peridial cells oblong, 16-23 x 23-29 $\mu$, slightly overlapping, the outer wall smooth, 5-8 $\mu$ thick, transversely striate, inner wall moderately verrucose, thinner, $2-4 \mu$; æciospores angularly globoid or broadly ellipsoid, 13-16 $\times 15-19 \mu$, the wall thin, $1 \mu$ or less, colorless, finely and inconspicuously verrucose.

"II. Uredinia hypophyllous, scattered, oblong, 0.5-2 mm. long, dehiscent by a longitudinal slit, cinnamon-brown, pulverulent, ruptured epidermis evident; urediniospores ellipsoid to obovoid, $15-21 \times 23-30 \mu$; wall moderately thin, $1.5-2 \mu$, cinnamon-brown, finely and closely echinulate, pores 2 , rarely 3 , equatorial.

"III. Telia hypophyllous, oblong or linear, 0.5-2 mm. long, chocolate-brown, covered by the epidermis, tardily dehiscent by a longitudinal slit; teliospores oblong or cylindrical, 15-22 $\times 42-44 \mu$, truncate, obtuse or rounded above, narrowed or rounded below, slightly or not constricted at the septum; wall moderately thin, 1-2 $\mu$, smooth considerably thickened at the apex, $6-10 \mu$ chestnut-brown above, paler below; pedicel tinted, one-half the spore lenght or less." Dr. f. C. Arthur's manuscript.

On Cyperus esculentus. 986. Uredospores, 1/12. 987. Teleutospores, 1/12.

Puccinta cil risanthemi Roze.-On the foliage of greenhouse chrysanthemums.

"If. Uredosori on both surfaces of leaf, but mostly hypophyllous, sparingly on stem, generally round, soon naked, powdery, scattered 

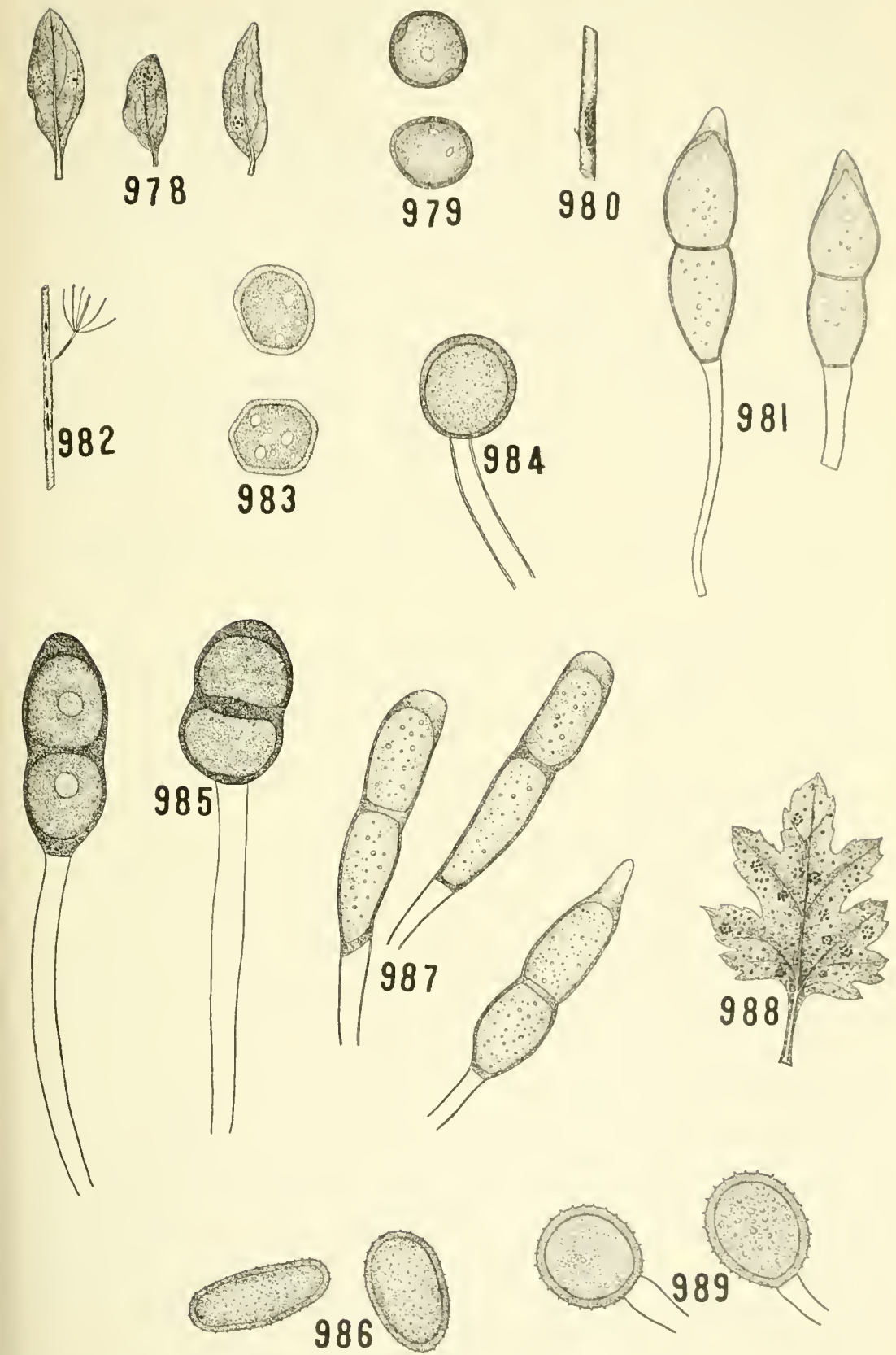
or crowded, often confluent, sometimes arranged circularly, snuffbrown, average 1-1 1/2 mm. diam., causing dirty-brown, indefinite spots on upper surface of leaf, which gradually extend and ultimately decay.

"Uredospores ellipsoid to obovoid, yellowish-brown to goldenbrown, echinulate, with 3 equatorial germ-spores on the face, 2S-35 $x 22-25 \mu$ (32 $\mu$ long very common, occasionally reaching a length of $45 \mu)$; pedicels hyaline, rarely persistent, stout, long, up to $60 \mu$.

"III. Teleutosori on both surfaces of leaf, but chiefly on under surface, prominent, roundish, pulvinate, solitary or confluent in groups, often concentrically arranged, dark-brown to black, soon naked, compact. "Teleutospores at first sparingly intermixed with uredospores, ellipsoid to pear-shaped or clavate, rounded or occasionally truncate at apex, and thickened (up to $9 \mu$ ) mostly rounded at base or sometimes slightly attenuated, chestnut-brown, with strong, finely punctulate epispore, $35-60 \times 19-28 \mu$; pedicel hyaline, stout, persistent, $40-80 \times 7-9 \mu$." McAlpine-Rusts of Australia, p. 153 (1906).

988. Infected leaf of chrysanthemum sp. 989. Uredospores, 1/12.

Puccinia coronata Cda. - On oats. Described by Sydow as follows :

"Aecidia hypophyllous, on the petiole, spots yellow or yellowishpurple, depressed in a circular fashion or irregularly distributed, distorting the foliage, and especially the petiole, cylindrical margin white, lacerated, folded back, xecidiospores angular to globose, delicately verrucose, golden colored, $16-25 \times 12-20 \mu$; uredosori hypophyllous, scattered or in series, somctimes confluent, more or less oblong, pulverulent, golden-colored, uredospores globose, subglobose or ovate, echinulate, yellow $20-30 \times 16-2+\mu$ possessing $3-4$ germination pores, paraphyses few, intermingled, teleutosori hypophyllous for the most part irregularly scattered, sometimes confluent, oblong or linear, covered a long time by the epidermis, at length naked, dark, teleutospores clavate, apices flattened, crowded with denticulate out-growths, middle not or very little constricted, base attenuate, sniooth, brown, 35-36 × 12-22 $\mu$; pedicel short, somewhat broad."

Hab. Aecia on leaf blade and petioles of Rhamnus sp., uredo and teleuto sori on leaves of oats, etc.

990. Uredosporcs, 1/12. 991. Teleutospores, 1/12. 
Puccinia cyani (Schleich.) Pass.-On cultivated Centaurea cyanus.

"II. Uredosori mostly hypophyllous, scattered or crowded, minute, orbicular or elliptic, pulverulent, reddish-brown.

"Uredospores yellowish-brown, globose, subglobose to ellipsoid fincly echinulate, with two germ-pores on one face, 25-27 × 19-24 $\mu$.

"III. Teleutosori amphigenous, and on stem, scattered pulverulent, dark-brown, orbicular to elliptic, soon naked, $1 / 2-1 \mathrm{~mm}$.

"Teleutospores intermixed with uredospores, chestnut-brown, ellipsoid, rounded at both ends, unthickened at apex, not constricted at septum, delicately warted, germ-pores conspicuous, 30-40 x $22-30 \mu$; average $32 \times 24 \mu$; epispore about $3 \mu$ thick; pedicel hyaline, short, deciduous." McAlpine-Rusts of Australia, p. 156 (1906).

992. Uredospores, $1 / 12$.

Puccinia douglasil E. \& E.-Teleutospore sori minute, 1/3-1/2 $\mathrm{mm}$. naked, surrounded by the adnate epidermis, pale, chestnutbrown color, often born in series, teleutospores oblong-ellipsoid 25-55 $\times 12-15 \mu$, chestnut-colored, constricted, apices rotund or obtusely long-pointed; epispore smooth, apices distinctly thickened, apex papillate or without a papilla.

Saccardo, P. A., Sylloge Fungorum, v. 11, p. 192.

993. Teleutospores, $1 / 12$.

Puccinia emaculata Schw.-On Panicum capillare. Described by Burrill as follows:

"II, III. Mostly epigenous, sometimes amphigenous. Sori small, rather prominent, mostly very numerous, irregularly scattered or crowded, rarely confluent on the leaves, but on the sheaths forming long, irregular lines, black, rather early erumpent, but long surrounded by the ruptured epidermis; uredospores subglobose, epispore rather thin, sharply but minutely echinulate, 15-24 $\mu$; teleutospores elliptical or broadly clavate, slightly constricted, vertex strongly thickened and obtusely pointed or rounded, narrowed below, smooth, not deeply colored, $15-21$ by $30-48 \mu$; pedicel once to once and a half as long as the spore, tinted." Parasitic Fungi of Illinois, v. 1, p. 201.

994. Uredospore, 1/12. 995. Teleutospore, 1/12.

Puccinia graminis Pers.-On wheat and grasses. Described by McAlpine as follows: 
"II. Uredosori amphigenous, yellowish-brown, linear, 2-3 mm. or longer, either scattered or confluent in long streaks, especially on sheaths, pulverulent, soon naked, surrounded by ruptured epidermis.

"Uredospores elongated ellipsoid to ovate oblong, brownish-yellow, echinulate, generally with 3-4 equatorial germ-pores on one face $20-36 \times 14-18 \mu$."

"III. Teleutosori sparingly on leaf blades, more commonly on sheaths, stalks and inflorescence, linear, elongated, pulvinate, often confluent, up to $10 \mathrm{~mm}$. or more, dark brown to dense black, soon rupturing epidermis which is prominent.

"Teleutospores clavate to oblong-clavate, chestnut-brown, smooth somewhat constricted at septum, very rarely 3 -celled, $35-63 \times 14-25$ $\mu$, average $52-\mathrm{x} 18 \mu$, upper cell rounded or pointed at apex, rarely truncate, considerably thickened (up to $12 \mu$ ) sometimes as broad as long 21-29 , long; lower cell attenuated towards base, equal to or longer than upper, 18-35 $\mu$ long; pedicel persistent, elongated, tinted, and sometimes as deeply colored as spore, of equal thickness throughout, up to $73 \times 8 \mu$

"Mesospores very common, intermixed in the same sorus with uredo and teleutospores, similarly colored, dark chestnut or paler, cblong to elongated ellipsoid, generally slender, rounded, pointed or truncated apex and thickened like teleutospore, smooth, 34-46 x 10-15 $\mu$; pedicel generally short or of moderate length. Occasionally an obovate form occurs, deeply colored, rounder and thickened at apex and much broader than usual, up to $22 \mu$, with elongated pedicel."-NcAlpine, Rusts of Australia, p. 120 (1906).

Note:- We find this rust on the stems only.

996. Infected wheat culm. 997. Uredospores, 1/12. 998. Teleutospores, $1 / 12$.

Puccinia grossularie (Schum.) Lagerh.-On Carex pallescens. Described by Arthur (manuscript) as follows:

"O. Pycnia chiefly epiphyllous, gregarious, on discolored spots, usually in groups, $0.5-1.5 \mathrm{~mm}$. across, honey-yellow becoming darker with age, flattened globose, 80-180 $\mu$ in diameter; 75-150 $\mu$ high, ostiola filaments $65-100 \mu$ long.

"I. Aecia chiefly hypophyllous, but appearing also on the twigs, petiole and young fruits, gregarious, usually appearing on more or less orange-colored hypertrophied areas, $2-8 \mathrm{~mm}$. across, cupulate, $0.2-0.3 \mathrm{~mm}$. in diameter, peridium short, spreading, the margin slightly recurved, irregularly dentate, peridial cells rhomboidal, 21-27 
$\mu$ long, the outer wall $6-8 \mu$ thick, striate, the inner wall $3-5 \mu$, verrucose, æciospores globose, $13-18 \times 15-21 \mu$, wall colorless, thin, about $1 \mu$, very finely verrucose."

On grossulariacee.

II. Uredinea chicfly hypophyllous, scattered, oval, or oblong, 0.1-0.5 mm. long, early naked, on some hosts rather tardily naked, somewhat pulverulent, ruptured epidermis usually not conspicuous, urediniospores globose, broadly ellipsoid or obovoid, 15-21 x 19-24 $\mu$ (rarely larger, up to 25 to $34 \mu$ ) wall golden-brown or chestnutbrown, 1.5-2 $\mu$ thick, moderately finely and evenly echinulate, the pores $2-4$, usually 3 , equatorial (or sometimes) partly or wholly (near the hilum).

III. Telia chiefly hypophyllous, scattered, rounded or oblong, 0.1-0.2 mm. broad by 0.1-0.5 mm. long, sometimes appearing longer when confluent end to end, early naked with ruptured epidermis not conspicuous, pulvinate, blackish-brown, or on some hosts long, covered by the epidermis and greyish to black, teliospores broadly clavate, $14-24 \times 32-58 \mu$, roundish truncate, or rarely accuminate above, slightly or not constricted at the septum, wall cinnamon or light chestnut-brown, 1-1.5 $\mu$ thick, thick at the apex, 4-10 $\mu$, smooth, pedicel one-half length of spore or less, slightly tinted.

999. Uredospores, 1/12, on Carex pallescens.

Puccinia meliantmi Schw.-On Helianthus annums. Described by McAlpine as follows:

"O. Spermogonia honey-colored, in small clusters. Aecidia crowded or orbicular, or arranged in broadly expanded, oblong spots; pseudoperidia cylindrical, plane, with white laciniate margins.

"I. Aecidiospores orange red, ellipsoid to polygonal, finely echinulate, $21-28 \times 18-21 \mu$.

"II. Uredosori roundish, chestnut-brown, scattered or confluent, pulverulent, often on yellow or pale green spots on upper surface of leaf, but generally forming brown mass on under surface.

"Uredospores subglobose, elliptic or obovate, golden yellow, echinulate, epispore sublyaline, showing one germ pore on one face, 21-24 $\mu$ diam. Or 24-29 x 15-22 $\mu$.

"III. Teleutosori roundish, dark brown or black prominent, scattered at first, but ultimately in clusters, confluent, dotting both surfaces of leaf, but most prominent on under.

"Teleutospores at first intermixed with urcdospores, chestnutbrown, oblong-elliptical or pear-shaped, smooth, but occasionally a 
little rough at apex, slightly constricted at septum, thickened at apex (6-9 $\mu$ ), generally rounded at base, $36-50 \times 21-27 \mu$, shade darker than lower, and rather larger, 22-29 x 21-27 $\mu$; lower cell either the counterfeit of upper or slightly tapering toward base, $17-23 \times 20-22 \mu$, pedicel hyaline, persistent, generalyy much longer than spore, up to 90 and $110 \mu$ long." McAlpine, Rusts of Australia, p. 158 (1906).

1000. Teleutospore, $1 / 12$.

Puccinia impatientis (Schw.) Arth. (Puccinia argentata (Schultz) Winter.) Uredo impatientia; (Caoma impatienta; Puccinia papillata).-On Impatiens biflora.

"Hypogenous. Spots sometimes definite, purple, yellow-bordered, more often effused, on the leaves scarcely thickened, on the petioles and stems swollen; æcidia subcircinate or irregularly scattered, short, deeply and rather coarsely split and much recurved; spores subglobose or elliptical (vertical diameter shorter), epispore thin, apparently smooth, contents finely granular, $15-18$ by $18-20 \mu$; spermogonia clustered above in the center of the definite spots, otherwise sparsely scattered on both sides of leaf." Burrill, Parasitic Fungi of Illinois, p. 224.

"Uredospore sori ochraceous or faintly cinnamon-colored, little congested, globose or ellipsoid, spores 16-20 × 14-16 $\mu$, slightly roughened, faintly yellowish, pedicel long, teleutospore sori chestnutbrown, forming spots, often confluent spores elliptical; oval or subclavate, constricted in the middle, apices rotund or attenuated, tip of the apex hyaline, $25-25 \times 12-20 \mu$. brown, granular, smooth, pedicel short, slender, hyaline."

Saccardo, P. A., Sylloge Fungorum, v. 7, p. 639.

1001. Aeciospores, $1 / 12$, on Impatiens biflora

Puccinia macrospora (Peck) Arthur.-Described by Arthur (manuscript) as follows:

"O. Pycnia epiphyllous, few in groups on slightly discolored spots, not conspicuous, subepidermal, in vertical section, flattenedgloboid, $128-160 \mu$ in diameter, by $80-100 \mu$ high.

"I. Aecia hypophyllous, chiefly in annular groups, $1.5-5 \mathrm{~mm}$. across, rather short, $0.1-0.2 \mathrm{~mm}$. in diameter; peridial cells linear, rhomboidal 32-42 $\mu$ long, outer wall thin, smooth, inner wall somewhat thicker, moderately verrucose, æciospores globoid, very large, $37-51 \times 32-42 \mu$, wall colorless, medium thick, 1.5-2.5 $\mu$ thicker above 5-10 $\mu$, rather coarsely verrucose, æcia on Smilax sp. 
"II. Uredinia amphigenous, scattered or in longitudinal series, oblong, $0.5-1 \mathrm{~mm}$. long, tardily dehiscent, urediniospores obovate or narrowly ellipsoid, rather irregular, very large, 40-60 × 26-37 $\mu$, often narrowed below to a thickened hilum, wall golden yellow, evenly thick, 2.5-3.5 $\mu$, echinulate, with prominent points, $3-4 \mu$ apart, pores obscure, 2 or sometimes 3 , equatorial.

"III. Telia chiefly hypophyllous, scattered or in longitudinal series, oblong or linear, 0.5-1.5 $\mathrm{mm}$. long, finally naked, pulvinate, chocolate-brown, ruptured epidermis noticeable, teliospores clavate, $61-67 \times 16-23 \mu$, usually rounded or obtuse above, narrowed below, usually slightly constricted at the septum; wall pale cinnamonbrown, paler below, medium thin, 1.5-2.5 $\mu$, much thicker at the apex, 9-16 $\mu$, pedicel nearly colorless, one half to one length of the spore. Telia on carex.

\section{Infected leaf of Smilax sp. 1003. Aeciospore, 1/12.}

Puccixia malvacearum Mont.-On the cultivated hollyhock and other species of Malva. Described by McAlpine as follows:

"III. Teleutosori generally hypophyllous, brown to reddishbrown or orange, but grayish when spores are germinating, compact, round, pulvinate elongate on stems, scattered or crowded, seldom confluent, at first covered by epidermis, soon naked.

"Teleutospores fusiform, attenuated at both ends, apex sometimes rounded, slightly constricted at septum or not at all, apical thickening slight, smooth, yellowish-brown, rarely tricellular, 35-75 x 12-26 $\mu$, average $50 \times 17 \mu$; pedicels firm, long persistent, occasionally septate, sometimes measuring $170 \mu$ long.

"X. Mesospores occasional, same color as teleutospores, somewhat fusiform, slightly thickened at apex, 40-45 x 17-19 $\mu$." McAlpine, Rusts of Australia, p. 178 (1906).

1004. Infected leaf of cultivated hollyhock. 1005. Teleutospore, 1/12.

Puccinia menth. Pers.--On Kollia virginiania. Described by Sydow as follows:

"Pycnia disposed in small groups or scattered, honey-colored, æcidia hypophyllous or often on the stem, reddish-purple spots on the foliage and in groups more or less regular on stems, petioles and veins of the leaves, producing distortions, æcia opening irregularly, margin hardly or irregularly lacerated, erect or curved, very little within, æcidiospores subglobose, ellipsoid or with many angles, verrucose, pale yellow, $24-40 \times 17-2 S \mu$; uredosori hypophyllous, yel- 
lowish or brown, orbicular or elliptical, scattered or aggregated, surrounded by the ruptured epidermis at maturity naked, now and then confluent, cinnamon-brown, uredospores globose, subglobose, ellipsoid or obovate, echinulate, pale brown 17-28 x 14-19 $\mu$, teleutospores sori hypophyllous, rarely on the stem, scattered or aggregated, minute, now and then confluent, orbicular, pulverulent, blackbrown, teleutospores ellipsoid, ovate or subglobose, rounded at both extremities, apex with a pale or hyaline papilla, middle of spore not or hardly constricted, verrucose, dark-brown, $26-35 \times 19-23 \mu$, pedicel long, delicate and hyaline."

1006. Telentospore, $1 / 12$, on species of mint.

Puccinia POLysora Underwood.-On Tripsacum dactyloides. Described by Underwood as follows:

"II, III. Amphigenous; sori very small, short, very numerous but irregularly scattered, remaining long enclosed in the tough epidermis of the host, at length rupturing by a narrow slit; uredo spores large, broadly oval, $35 \times 30 \mu$, scarcely echinulate, the epispore or medium thickness, pale rusty brown; teleutospores variable, usually short, irregularly oblong, often somewhat constricted at the septum, averaging $25 \times 40 \mu$, the cells often irregularly angled, the upper usually broader than longer, blunt or rounded above; apex not thickened; pedicel usually short."

\section{Uredospores, $1 / 12$.}

Puccinia sambuci (Schw.) Arthur. - On Carex bullata. Described by Arthur (manuscript) as follows:

"O. Pycnia chiefly epiphyllous and caulicolous, numerous, gregarious, more or less crowded in orbicular groups, 1-5 mm. across, conspicuous, punctiform, orange-yellow becoming brownish, globoid, $120-155 \mu$ in diameter, $112-144 \mu$ high, ostiolar filanients $50-90 \mu$.

"I. Aecia hypophyllous and caulicolous, crowded in orbicular groups on the leaves, 0.1-0.5 mm. or more across on thickened, discolored spots, or crowded over hypertrophied areas, often of considerable extent, on the stem and petiole, short 0.3-0.7 mm. in diameter, bright orange-yellow, peridia colorless, margin recurved, erose, peridial cells squarish in longitudinal sections, isodiametric, 15-25 $\mu$, inner wall moderately thick, 3-4 $\mu$, verrucose, outer walls thick. 7-12 $\mu$, striate, smooth, xciospores globoid, 15-19 in diameter, wall pale yellow, thin, about $1 \mu$, finely verrucose. 
"II. Uredinia chiefly hypophyllous, scattered, elliptical, 0.1-0.3 $\mathrm{mm}$. broad by 0.2-0.7 mm. long, early naked, pulverulent, chestnutbrown, ruptured epidermis conspicuous, urediniospores lenticular or ellipsoid, $17-21 \times 23-32 \mu$; wall light chestnut-brown, about $1.5 \mu$ thick, rather finely echinulate, the pores 2 , in the upper part near apex.

"III. Telia chiefly hypophyllous, scattered, oblong, or lemon-oblong, 0.3-0.6 mm. broad by $0.4-5 \mathrm{~mm}$. or more long early naked, pulvinate, dark chocolate-brown, surrounding epidermis conspicuous, teliospores, clavate-oblong or clavate, $15-25 \times 42-65 \mu$, rounded above, usually narrowed below, somewhat constricted at the septum, wall chestnut-brown, concolorous, $1.5-2 \mu$ thick, thicker at apex, $7-13$ $\mu$, smooth pedicel nearly or quite colorless about length of spore."

1008. Infected petiole and bud of Sambucus sp. showing æcia. 1009. Aeciospore, 1/12. 1010. Teleutospores, 1/12, from Carex bullata var. greenii.

Puccinia smilacis Schw.-On smilax. Described by Sydow as follows:

"Uredospore sori hypophyllous, spots orbicular or irregular, ofien confluent, for the most part brick red, scattered or irregularly circinate, minute, rotund, or oblong, surrounded by ruptured epidermis, pulverulent, uredospores subglobose or ovate, delicately echinulate pale, $21-28 \mu$ in diameter, teleutospore sori, hypophyllous, scattered, grouped or circinate, rotund or irregular, minute, subpulvinate, surrounded by ruptured epidermis, black teleutospores ellipsoidoblong or oblong, apex rotund or obtuse, thickened (15-12 $\mu$ ) middle constricted, base rotund or slightly attenuate, chestnut-brown, smooth,* 35-45 × 16-22 $\mu$, pedicel brown, thick, long."

1011. Infected leaf of Smilax sp. 1012. Teleutospore, 1/12.

Puccinia sorgin Schw. (Puccinia maydes Bereng).-On the foliage, sheaths and stems of corn.

"Sori of uredospores amphigenous, numerous, elliptical or spherical, scattered or close together, therefore confluent, convex, at maturity swelling out or pushing out the epidermis which ruptures in a longitudinal fashion, brown, becoming reddish; uredospores globose, elliptical or ovate, $23-30 \times 22-26 \mu$, somewhat verrucose, sometimes guttulate, at first yellowish, at length reddish-brown; pedicel short cylindrical, hyaline; sori of teleutospores of various forms, for the most part linear, or oblong, prominent amphigenous, subepidermal, white, at length, rupturing there, becoming convex, superfi-

*On Smilax sp. 


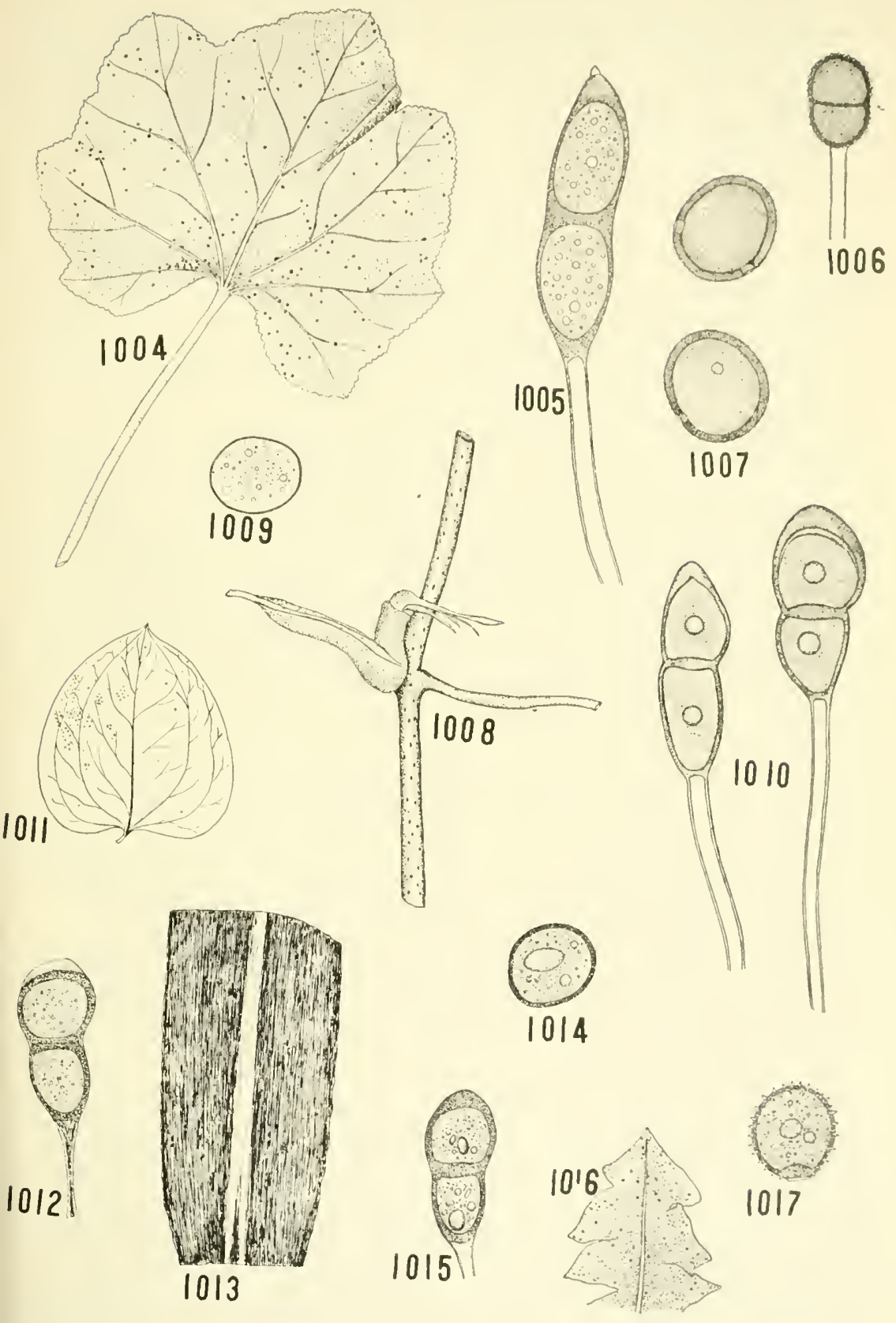


cial and dark; teleutospores ovate-oblong or clavate, obtuse, constricted in the middle, upper cells sometimes long-pointed; epispore thick, at first dirty-yellow in color, at length dark brown, at maturity quite dark, 28-45 $\times 12-17 \mu$, smooth, pedicel elongate about $5 \mu$ thick, cylindrical, persistent, somewhat thickened above."

Modified description taken from Sacc. Syll., v. 7, p. 659.

1013. Portion of infected corn leaf. 1014. Uredospore, 1/12. 1015. Teleutospore, $1 / 12$.

Puccinia taraxaci (Ruben) Plowr.-On leaves of dandelion. Described by Sydow as follows:

"Uredospore sori amphigenous, often on spots, often without spots, scattered, sometimes confluent, minute, rotund or oblong, pulverulent, brown, uredospore globose, subglobose or ovate, echinulate, light brown, $22-27 \times 16-24 \mu$, teleutospore sori similar, about $1 / 2-3 / 4 \mathrm{~mm}$. in diameter, dark or black-brown, teleutospores ellipsoid or ovate-ellipsoid, apex rotund not thickened, middle of spore not or slightly constricted, base for the most part rotund, delicately verrucose, brown 25-38 x 16-24 $\mu$, epispore thin, pedicel hyaline, short."

1016. Infected portion of leaf of Taraxacum taraxacum. 1017. Uredospore, $1 / 12$.

Puccinia triticina Eriks.-On wheat. Described by McAlpine as follows:

"II. Uredosori 1-2 mm. long, reddish-brown, amphigenous but mostly on upper surface of leaf blade, elliptic, sometimes confluent, scattered or somewhat gregarious, occasionally on sheath and stem."

"Uredospores subglobose to shortly ellipsoid, echinulate, orangeyellow, 4-6 scattered germ pores on one face, 20-28 x 18-21 $\mu$."

"II. Teleutosori oblong, black, to dark brown, hypophyllous, scattered, often arranged lengthwise in lines, sometimes on sheath and stem, covered by epidermis, divided into compartments surrounded by brown paraphyses."

"Teleutospores clavate to oblong, smooth, yellowish-brown to dark-brown, slightly constricted at septum, very occasionally 3celled, 39-57 × 15-18 $\mu$, average 48-16 $\mu$; upper cell deeply colored, generally rounded or flattened at apex and thickened, $17-31$ x 15-18 $\mu$; lower cell paler and attenuated towards pedicel, longer and narrower than upper, 22-36 $\times 12-14 \mu$; pedicel short, colored."

"X. Mesospores occasional, similarly colored to teleutospores, ellipsoid to clavate or sub-clavate, shortly stalked, smooth, slightly 
thickened at apex, 25-38 × 13-16 $\mu$." McAlpine, "The Rusts of Australia," p. 132 (1906).

1018. Part of infected leaf of wheat. 1019. Same showing sori, 2/3. 1020. Uredospore, 1/12. 1021. Teleutospores, 1/12.

Puccinia xanthil Schw.-On Xanthium sp. Described by Burrill as follows:

"III. Hypophyllous. Sori small, mostly closely clustered in spots or patches; spores smooth, oblong, evidently constricted, apex slightly thickened, round, or beak-like, 15-21 by 36-51 $\mu$; pedicel slightly colored, usually shorter than spore." Parasitic Fungi of Illinois I, 184.

1022. Under side of infected leaf of Xanthium sp. 1023. Teleutospore, 1/12. 1024. Germinating teleutospores, 1/12.

Cæoma nitens, Schw.-On the leaves of cultivated blackberry and raspberry. Described by Burrill as follows:

"Hypophyllous. Sori irregular, flat, usually thickly associated and confluent, more or less covering the surface, bright orange-yellow; spores subglobose, elliptical or oblong, epispore thin, finely tuberculate, $12-24$ by $18-32 \mu$; spermagonia scattered, ntumerous, yellow, mostly on upper side of the leaf." Parasitic Fungi of Illinois, p. 220.

1025. Infected leaf of dewberry. (R. canadensis). 1026. Cross-section of same, 2/3. 1027. Spores, 1/12. 1028. Germinating spores, 1/12.

Nigredo Caladil (Schw.) Arth.-On Arisama triphyllum.

"O. Pycnia from a peremial mycelium, chiefly hypophrllous, sometimes occurring also on the floral parts, evenly and extensively scattered over large areas, preceding or accompanying the rcia, abundant, punctiform, noticcable, half immersed, honey-yellow, becoming brownish, globose, 100-160 $\mu$ in diameter, 96-128 $\mu$ high ; ostiolar filaments rather short, 35-50 $\mu . "$

"I. Aecia from a perennial mycelium, chiefly hypophyllous, rather evenly and extensively scattered, short becoming cuculate, about 0.2-0.4 mm. in diameter, peridium colorless, the margin erect or somewhat spreading and recurved, finely eroded or sparingly lacerate, peridial cells oblong or slightly rhomboidal, about $23-32 \mu$ long, 15-19 $\mu$ thick, the inner wall moderately verrucose, 3-4 $\mu$, the outer wall inconspicuously striate, $6-8 \mu$; xciospores subglobose or ellipsoid $15-20$ by $17-24 \mu$; wall pale yellow, moderately thin, about $1.5 \mu$, evenly and finely verrucose." 
"II. Uredinia amphigenous, scattered, roundish, 0.5-0.8 mm. across, rather tardily naked, light cinnamon-brown, ruptured epidermis conspicuous; urediniospores ellipsoid, obovoid, or sometimes almost cuneiform, $15-24$ by $24-35 \mu$, rounded above, often narrowed and rather sparingly echinulate, the pores 4, equatorial."

"III. Telia amphigenous, scattered, roundish, or often irregular, rather tardily naked, light chestnut-brown, ruptured epidermis conspicuous; teliospores ellipsoid or obovoid, 17-24 by 23-35 $\mu$, rounded or obtuse above and below, wall cinnamon-brown, 1.5-2 $\mu$ thick, with a small hyaline papilla at apex, 3-5 $\mu$, smooth; pedicel hyaline, short, deciduous." North American Flora, v. 7, p. 236 (1912).

1029. Infected spathe of Arisaema triphyllum. 1030. Aeridium, 2/3. 1031. Cross-section of leaf showing aecidium, 2/3. 1032. Peridial cell, 1/12. 1033. Aeciospores, 1/12.

Nigredo fallens (Desmaz.) Arth.-On Trifolium pratense.

"O. Pycnia and æcia uncertain. II. Uredinia chiefly hypophyllous, scattered, rather early naked, roundish or oval, 0.3-0.8 mm. in diameter, pulverulent, pale, cinnamon-brown, ruptured epidermis conspicuous; urediniospores broadly ellipsoid or obovate-ellipsoid $19-23$ by $22-26 \mu$; wall light cinnamon-brown $1.5-2 \mu$ thick, rather sparsely echinulate, the pores 4-6 scattered."

"III. Telia chiefly hypophyllous, scattered, rather tardily naked, roundish or oval, $0.3-0.8 \mathrm{~mm}$. in diameter, somewhat pulverulent, dark cinnamon-brown, ruptured epidermis conspicuous; teliospores broadly ellipsoid or obovoid, $16-20$ by $20-27 \mu$; wall cinnamonbrown, moderately thick, 1.5-2 $\mu$, often with an inconspicuous hyaline papilla over the germ-pore, smooth, or more usually with a few irregularly scattered, roundish warts; pedicel short, hyaline, deciduous." North American Flora, v. 7, p. 254 (1912).

Note:-The recial stage on red clover was reported at the New York meeting of the American Phytopathological Society, Decemwer, 1916. by WI. H. Davis and A. G. Johnson.

1034. Infected leaf of Trifolium pratense. 1035. Teleutospores, 1/12.

Nigredo plumbaria (Peck.) Arth.-On Enothera biennis.

"O. Pycnia chiefly hypophyllous, rather few, loosely scattered, punctiform, honey-yellow becoming brownish, flattened, glol,oid, $128-144 \mu$ in diameter by $82-112 \mu$ high."

"I. Aecia chiefly hypophyllous, numerous, rather evenly and thickly effused over large areas, often occupying all of the under 
Parasitic Fungi of New Jersey
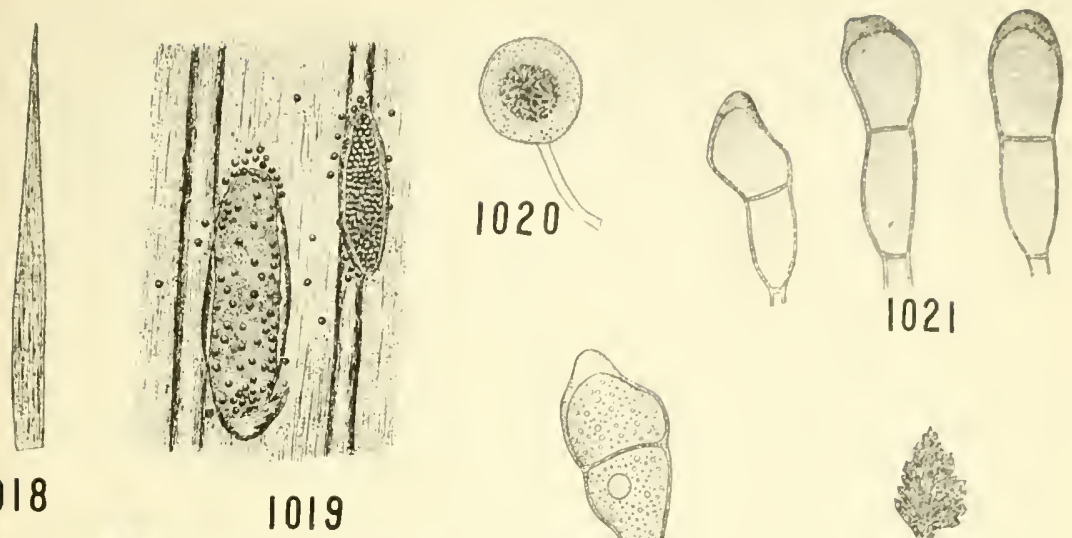

1018
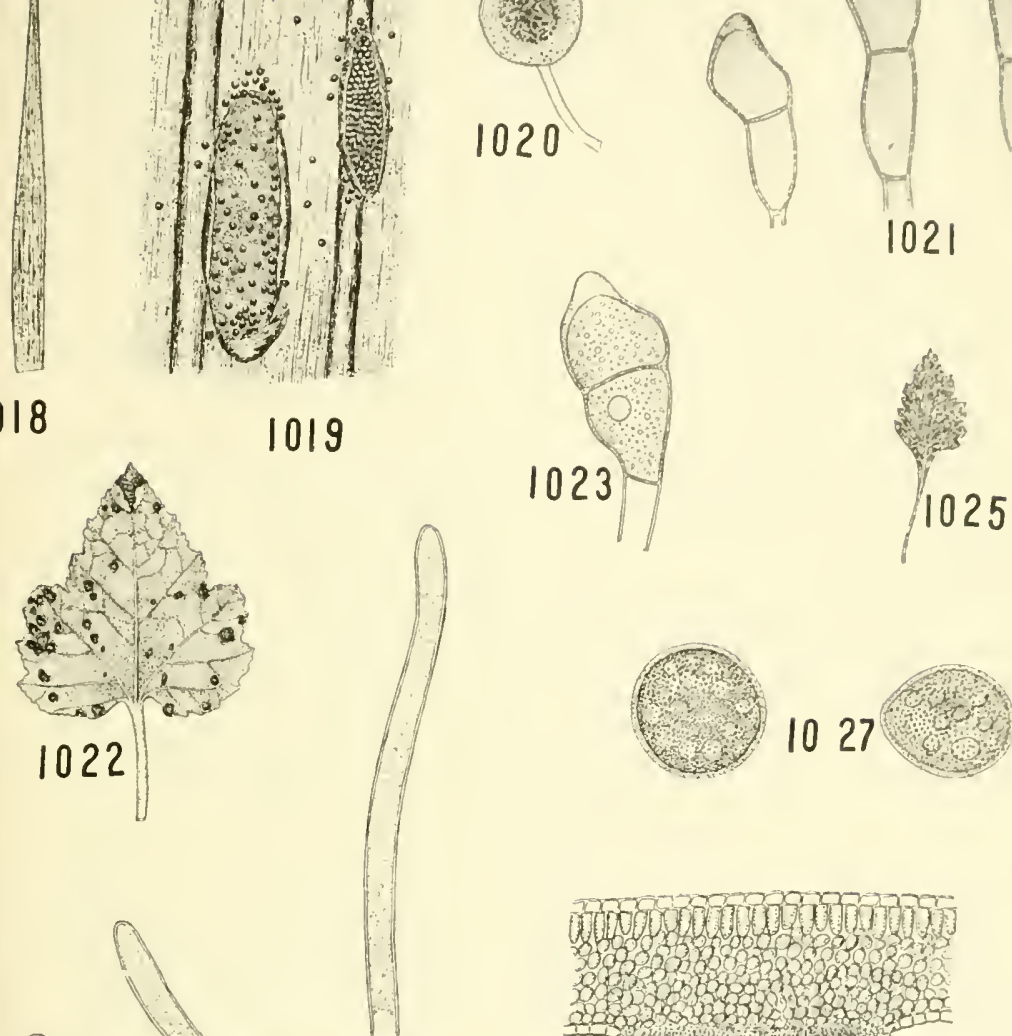

1027
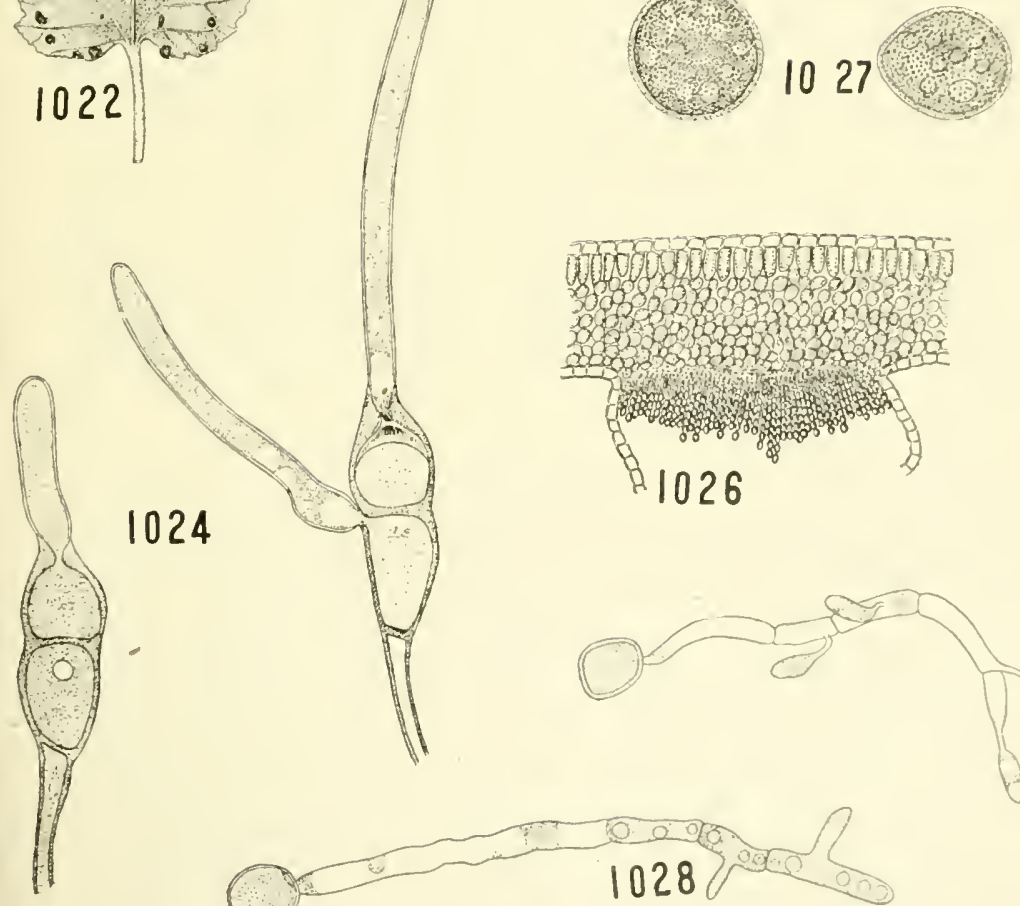

쏭

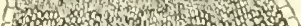

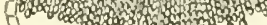

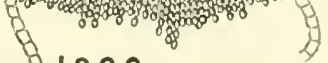

$\$ 1026$
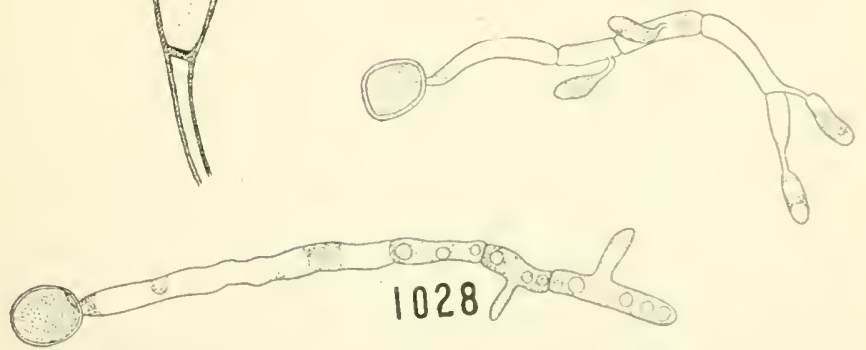
surface of a leaf, cupulate, short, 0.2-0.4 mm. in diameter; peridium whitish, the margin spreading or somewhat recurved, irregularly lacerate; peridial cells rhomboidal, $12-16$ by $16-24 \mu$, the outer wall rather thick, 6-7 $\mu$, striate, the inner wall thinner, 3-4 $\mu$, moderately verrucose ; æciospores globoid, $12-16$ by $14-18 \mu$; wall colorless, thin, 1-1.5 $\mu$, finely verrucose."

"II. Uredinia amphigenous, scattered, roundish, about 0.4-0.7 mm. across, rather early naked, pulverulent, dark cinnamon-brown, ruptured epidermis noticeable; urediniospores broadly ellipsoid or obovoid, $15-23$ by $20-26 \mu$, wall golden-brown, $1.5-2 \mu$ thick, finely and rather sparsely echinulate, the pores 2 or 3 , approximately equatorial."

"III. Telia amphigenous, scattered, roundish or oval, $0.5-1 \mathrm{~mm}$. or more across, rather early naked, somewhat pulverulent, slightly pulvinate, chocolate-brown, ruptured epidermis conspicuous; teliospores obovate or oblong, 15-23 by 22-35 $\mu$, roundish, obtuse, or less often acute above, usually narrowed below; wall light to dark cinnamon-brown, moderately thick, 2-2.5 $\mu$, much thicker at the apex, 5-10 $\mu$, smooth pedicel somewhat tinted next to the spore, fragile, about one and a half times length of spore, usually broken away and appearing short." North American Flora, v. 7, p. 262 (1912).

1036. Uredospores, $1 / 12$.

Nigredo polygoni (Pers.) Arthr.-On Polygonum sp.

"O. Pycnia amphigenous, few, in small groups, about $0.5 \mathrm{~mm}$. across, inconspicuous, honey-yellow becoming brownish, depressedgloboid, 112-144 $\mu$ in diameter, 75-100 $\mu$ high, ostiolar filaments $75-$ $90 \mu$ long."

"I. Aecia amphigenous, gregarious, in annularly or crowded groups 1-1.5 mm. across, on discolored spots, short, cupulate, or occasionally somewhat elongate, 0.1-0.2 $\mathrm{mm}$. in diameter; peridium colorless, the margin cross; peridial cells rhomboidal 26-32 $\mu$ long, overlapping, the outer wall rather thick, $6-8 \mu$, transversely striate, the inner wall thinner, $2-3 \mu$, somewhat striate, very moderately verrucose; xciospores globoid, $15-18$ by $16-19 \mu$; wall light yellow or colorless, thin, $1 \mu$, finely verrucose."

"II. Uredinia amphigenous, scattered, roundish, 0.3-0.8 mm. across, early naked, somewhat pulverulent, cinnamon-brown, ruptured epidermis conspicuous; urediniospores broadly ellipsoid or obovoid, $15-22$ by $19-27 \mu$; wall golden-brown $1.5-2 \mu$ thick, finely and closely verrucose, the pores 4 , equatorial." 
"III. Telia amphigenous, scattered, oval or oblong, 0.5-1 111m. long, often confluent, early naked, pulvinate, chocolate-brown, ruptured epidermis noticeable; teliosporcs broadly ellipsnid or obovateellipsoid, $16-24$ by $23-32 \mu$, slightly narrowed below, usually rounded above; wall cinnamon-brown, $2-3 \mu$ thick, thicker at apex, 4-7 $\mu$, smooth; pedicel hyaline, once to twice length of spore." North American Flora, v. 7, p. 243 (1912).

1037. Uredospore, 1/12. 1038. Teleutospores, 1/12.

Nigredo seditiosa (Kern) Arth.-On Aristida purpurascens.

"O. Pycnia amphigenous, few, on discolored spots $0.5-4 \mathrm{~mm}$. across, inconspicuous, honey-yellow becoming brownish, subglobose, laterally compressed, $80-100 \mu$ in diameter by $100-112 \mu$ high ; ostiolar filaments $46-65 \mu$ long."

"I. Aecia amphigenous, gregarious, in crowded or sometimes annular groups on discolored spots $0.5-4 \mathrm{~mm}$. across, cupulate or short cylindrical, $0.2-0.3 \mathrm{~mm}$. in diameter; peridium colorless, the margin erose, erect or somewhat recurved; peridial cells rhombic in longitudinal section, $17-19$ by $28-35 \mu$, the outer wall very thick. $10-13 \mu$, transversely striate, smooth, the inner wall thinner, 4-5 $\mu$, somewhat striate, moderately verrucose, xciospores subglobose or broadly ellipsoid, $14-18$ by $16-22 \mu$; wall colorless, rather thin, $1.3 \mu$, finely verrucose."

"II. Uredinia epiphyllous, scattered, linear or oblong, cinnamonbrown, moderately thick, $2-2.5 \mu$, very minutely verrucose, appearing almost smooth when wet, the pores rather indistinct, 4 , equatorial."

"III. Telia epiphyllous, scattered or sometimes crowded and irregularly confluent, oblong, or linear, $0.2-0.5 \mathrm{~mm}$. wide by $0.5-1 \mathrm{~mm}$. or more long, early naked, conspicuous, compact, pulvinate. dark chocolate-brown, ruptured epidermis not noticeable, teliospores broadly ellipsoid, or obovoid to nearly globoid, 15-21 by 23-29 $\mu$, rounded or obtuse at both ends; wall chestnut-brown usually with a slightly paler umbo, about $1.5-2 \mu$ thick, much thicker at apex, 5-10 $\mu$ smooth; pedicel slightly colored, rather stout, once to twice length of spore." North American Flora, v. 7, p. 225 (1912).

1039. Teleutospores, $1 / 12$.

Nigredo spermacoces (Schw.) Arth.--On Diodia teres.

"O. Pycnia epiphyllous, few, gregarious, inconspicuous, ycllowish, 
becoming darker with age, globoid, $120-140 \mu$; ostiolar filaments apparently rather short."

"I. Aecia hypophyllous, crowded in irregular groups 1-2.5 mm. across, short, cupulate, $0.2-0.3 \mathrm{~mm}$. in diameter peridium colorless, erect, the margin lacerate; peridial cells rhomboidal, $13-19$ by 29-34 $\mu$, somewhat orerlapping, the outer wall 4-6 $\mu$ thick, transversely striate, the inner wall, rather coarsely verrucose; æciospores globoid, 21-26 by 21-28 $\mu$; wall colorless, $1-1.5 \mu$, inconspicuously verrucose."

"II. Uredinia chiefly epiphyllous, numerous, scattered, roundish, 0.2-0.5 mm. across, tardily naked, pulverulent, light cinnamonbrown, the over-arching epidermis ruptured by an uneven slit; urediniospores broadly ellipsoid, $18-24$ by $26-32 \mu$; wall golden-brown, 1-2 $\mu$, rather finely echinulate, the pores 2 , opposite, equatorial.

"III. Telia amphigenous and caulicolous, numerous, scattered, crowded and confluent on stems, roundish or oval, 0.2-1 mm. across, rather early naked, compact, pulvinate, blackish, ruptured epidermis at first conspicuons, later disappearing; teliospores broadly ellipsoid, 19-27 by 29-37 $\mu$; wall dark chestnut-brown, thick, $2-3 \mu$, with a lighter-colored broad cap making the wall at the apex 6-10 $\mu$ thick, smooth; pedicel light-yellow, usually persistent, uniform, about twice the length of the spores." North American Flora, v. 7, p. 266 (1912).

\section{Teleutospores, $1 / 12$.}

Nigredo trifolin (Hedw.) Arth.-On Trifolium repens.

"O. Pycnia chiefly epiphyllous, in small groups or sometimes spread out over larger areas, not conspicuous, honey-yellow becoming reddish-brown, globoid, $100-130 \mu$ in diameter; ostiolar filments up to $30 \mu$ long.

"I. Aecia amphigenous, in roundish crowded groups or on the veins and petioles in elongate groups, short, cupulate, $0.2-0.3 \mathrm{~mm}$. in diameter; peridium white, the margin erect or slightly recurved, finely erose; peridial cells rhomboidal, slightly overlapping, 13-15 $\mu$ broad by $18-26 \mu$ long, the outer wall rather thick, 5-6 $\mu$, transversely striate, smooth, the inner wall thinner, $2-3 \mu$, moderately verrucose; xciospores broadly ellipsoid or somewhat angular, 15-17 by $16-21 \mu$; wall light-yellow or nearly colorless, thin, about $1 \mu$, finely verrucose."

"II. Uredinia ampligenous, scattered, oval or roundish, 0.3-0.6 mm. in diameter, rather tardily naked, pulverulent, cinnamon- 

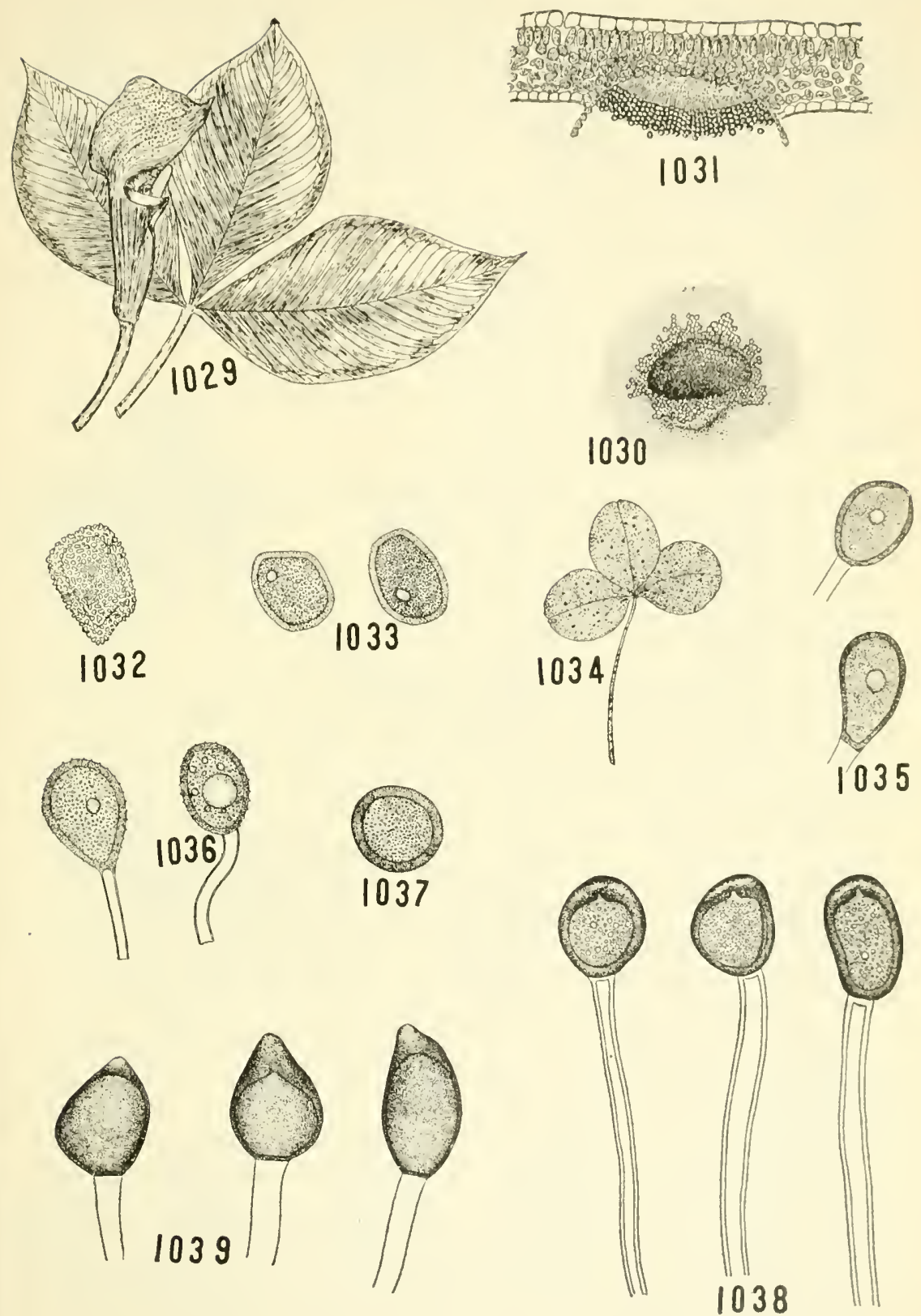
brown, ruptured epidermis conspicuous; urediniospores broadly ellipsoid, $18-21$ by 21-26 $\mu$, wall golden-brown, rather thin, about 1.5 $\mu$, rather sparsely echinulate, the pores 3 or 4 , equatorial."

"III. Telia chiefly hypophyllous, scattered, oval or roundish, variable in size, $0.3-0.8 \mathrm{~mm}$. or more in diameter, rather tardily naked, somewhat pulverulent, chestnut-brown, ruptured epidermis conspicuous; teliospores broadly ellipsoid or obvate-ellipsoid, 13-19 by $20-29 \mu$; wall cinnamon-brown, rather thin, about $1.5 \mu$, with a small hyaline papilla over the germ-pore, smooth, or with a few, small sparsely scattered papilla; pedicel colorless or slightly tinted, short." North American Flora, v. 7, p. 255 (1912).

1041. Infected leaf of Trifolium repens. 1042. Peridial cell, 1/12. 10+3. Aeciospore, 1/12. 1044. Uredospore, 1/-2.

Nigredo Preminens (D. C.) Arthur.-On Euphorbia preslii, described by Arthur (manuscript) as follows:

Pycnia hypophyllous, widely scattered among the æcia, rather few, punctiform, honey-yellow becoming brownish, globoid, 130-145 $\mu$ in diameter; ostiolar filaments up to $65 \mu$ long.

Aecia chiefly hypophyllous, from an unlimited mycelium, usually occupying all of the under surface of the affected leaves, evenly and often densely scattered; short, cupulate, 0.3-0.4 mm. in diameter; peridium somewhat recurved, lacerate; peridial cells rhomboidal, somewhat overlapping, 13-19 $\mu$ broad by 18-25 $\mu$ long, the outer wall rather thick, $4-7 \mu$, transversely striate, smootl, the inner wall thinner, about $3 \mu$, somewhat striate, somewhat verrucose; æciospores globoid or broadly ellipsoid, $12-16$ by $15-19 \mu$, wall pale yellow or colorless, thin, $1 \mu$, finely and densely verrucose.

Uredinia amphigenous, scattered or sometimes in annular or crowded groups, roundish, 0.4-1 mm. across, early naked, pulvinate, pulverulent, cinnamon-brown, ruptured epidermis not conspicuous; urediniospores globoid or broadly ellipsoid, $15-20$ by $19-23 \mu$; wall pale golden brown, rather thin, about $1.5-2 \mu$, moderately and sparsely echinulate, the pores 3-6, scattered.

Telia amphigenous, scattered or sometimes in annular groups, roundish, 0.4-1 mm. across, early naked, pulvinate, somewhat pulverulent, dark chocolate-brown, ruptured epidermis not conspicuous; teliospores broadly ellipsoid or obovoid, 15-18 by 18-26 $\mu$, usually rounded at both ends; wall cinnamon-brown, rather thin, $1.5 \mu$, with a lighter-colored, flattish or conical papilla over the germ-pore, moderately virucose with papillæ scattered or sometimes arranged 


\section{Parasitic Fungi of New Jersey}
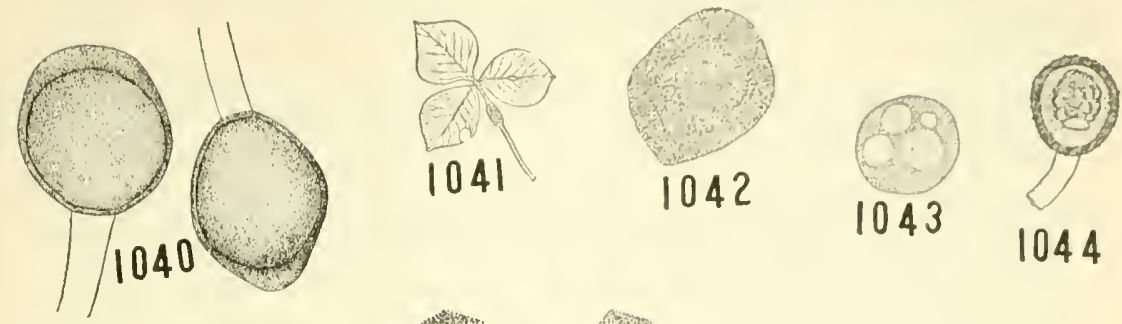

1046

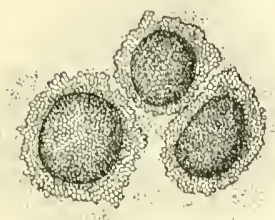

1045
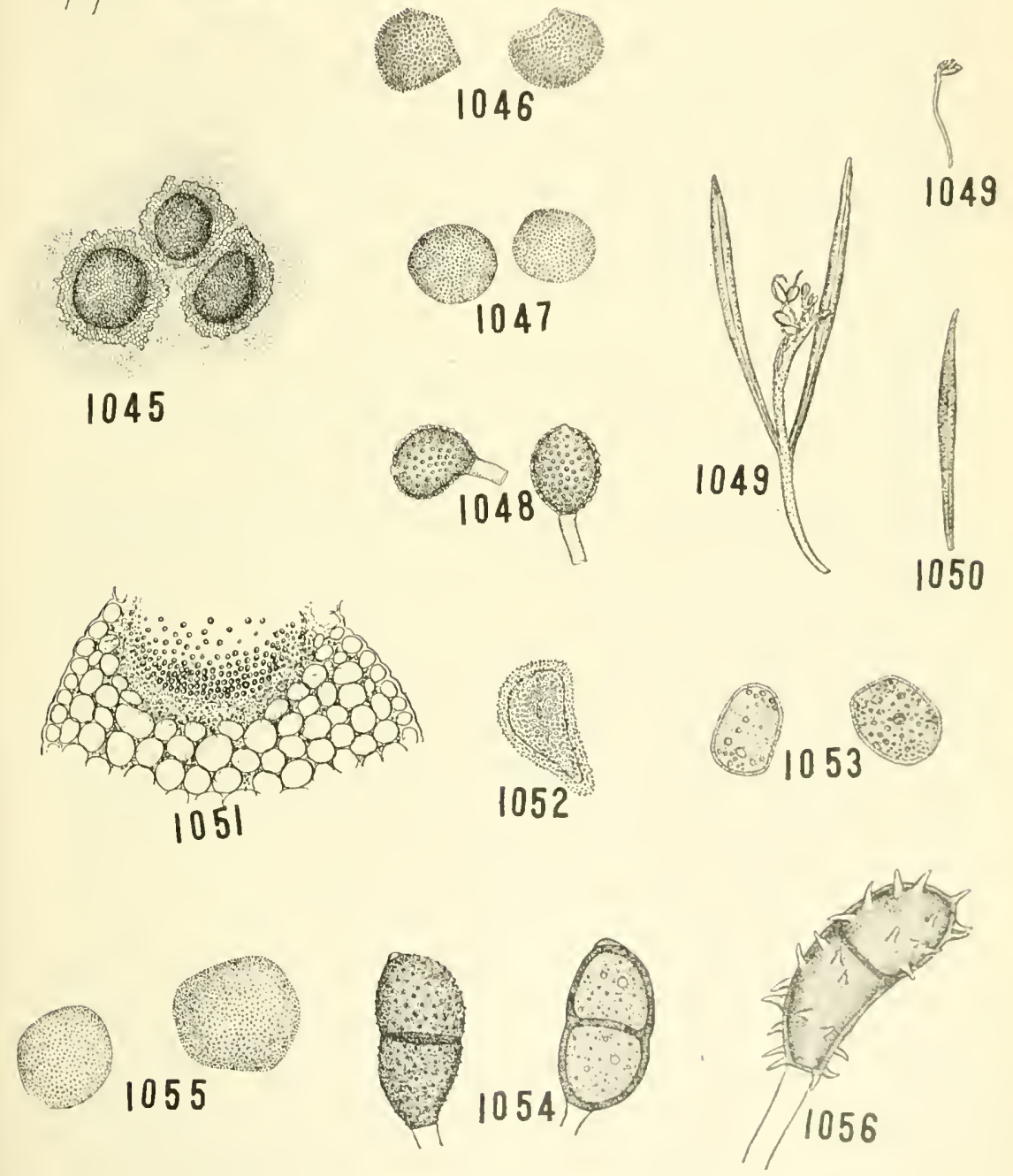
in more or less evident longitudinal rows: pedicel hyaline, short, deciduous."

1045. Aecia, 2/3. 1046. Peridial cells, 1/12. 1047. Aeciospores, 1/12. 1048. Uredospores, $1 / 12$.

Allodus Claytoniata (Schw.) Arth.-On Claytonia virginica. "Aecia amphigenous, regularly scattered, often over large areas and corering entire leaf and petiole, æciospores $13-21$ by $18-23 \mu$; wall $1-1.5 \mu$ thick.

Telia chiefly hypophyllous, of ten thickly scattered, sometimes confluent, small roundish, tardily naked, cinnamon-brown, pulvinate, ruptured epidermis noticeable, teliospores elliptical to terete, sometimes angular, $18-27$ by $30-48 \mu$; wall light cinnamon-brown, $1.5-2 \mu$ thick, apex often thickened up to $\tau \mu$ by a hyaline papilia, evenly and finely verrucose ; pedicel colorless, short." Orton, C. R., North American Species of Allodus.-Mem. N. Y. Bot. Garden 6, p. 184 (1916).

1049. Infected plant of Claytonia virginica showing æcia. 1050. Infected leaf of same showing teleutospores. 1051. Cross-section of æcia, 2/3. 1052. Peridial cell, 1/12. 1053. Aeciospores, 1/12. 105t. Teleutospores, 1/12.

Allodus podophylli (Schw.) Arth.-On Podophyllum peltatum. "Aecia chiefly hypophyllous, closely gregarious on yellowish spots, sometimes over large areas; æciospores $18-24$ by 19-29 $\mu$; wall about $1 \mu$ thick, minutely verrucose."

"Telia amphigenous and caulicolous, small, round, often gregarious in more or less orbicular areas on yellowish spots, tardily naked, chocolate-brown; teliospores clavate to elliptical, $19-26$ by $40-55 \mu$, wall chestnut-brown, uniformly 1.5-2 $\mu$ thick, sparingly beset with spines about $7 \mu$ long; pedicel golden yellow, rarely half length of spore." Orton, C. R., North American Species of Allodus.-Mem. N. Y. Bot. Garden 6, p. 187 (1916).

1055. Aeciospores, 1/12. 1056. Teleutospore, 1/12. 


\section{HOST INDEX}

Abutilon Abutilon

PAGE

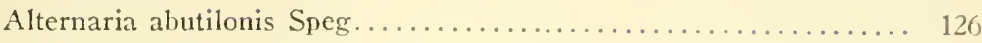

Acer sp.

Nectria cinnaharina (Tode) Fr.................... 34

Phyllosticta acericola C. \& E....................... 62

Rhytisma accrinum (Pers.) Fr....................... 24

Acalypha virginica

Cercospora acalyphæ Peck......................... 128

Acer platanoides

Nectria cinnabarina (Tode) Fr....................... 34

Acorus calamus

Septocylindrium aromaticum Sacc................... 118

Aesculus hippocastanum L.

Guignardia aesculi (Pk.) V. B. Stewart................. 42

Agave sp.

Coniothyrium concentricum (Desm.) Sacc................. 80

Agrostis alba

Ustilago striæformis (West.) Niessl.................... 154

Allium cepa $\mathbf{L}$.

Urocystis cepulæ Frost............................ 158

Vermicularia circinans Berk............................... 74

Alnus sp.

Microsphæra alni (Wallr.) Wint.................... 28

Phyllactinia corylea (Pers.) Karst..................... 28

Althæa rosea Cav.

Ascochyta althæina Sacc. \& Bizz..................... 82

Amaranthaceæ

Albugo bliti (Biv.) Kuntze......................... 6

Amaranthus chlorostachys

Albugo bliti (Biv.) Kuntze......................... 6

Amaranthus hybriclus

Albugo bliti (Biv.) Kuntze........................ 6

Ambrosia artemisiifolia

Rhysotheca halstedii (Farlow) Wilson................. 10

Amelanchier sp.

Gymnosporangium transformans (Ellis.) Kern................ 175

Amelanchier canadensis

Dimerosporium collinsii (Schw.) Thüm.................. 34

Ampelopsis sp.

Phyllosticta ampelopsidis E. \& M..................... 62

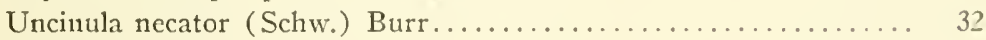

Andropogon sp.

Gnomonia andropogonis E. \& E.................... 58

Andropogon virginicus

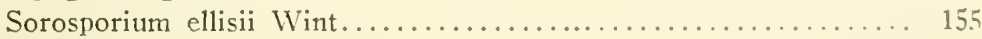

Antirrhinum majus

Colletotrichum antirrhini Stew...................... 102

Puccinia antirrhini Dietl \& Holw...................... 178 
Apium graveolens L.

Cercospora apii Fr............................... 130

Septoria petroselini Desm. var. apii Br. \& Cav................ 92

Arisæma triphyllum

Nigredo caladii (Schw.) Arthur........................ 193

Aristida purpurascens

Nigredo seditiosa (Kern.) Arthur......................... 197

Aristolochia macrophylla

Phyllosticta aristolochiæ F. Tassi....................... 62

Aronia arbutifolia

Gymnosporanigum transformans (Ellis) Kern.............. 175

Arrhenatherum elatius

Ustilago perennans Rostr............................ 152

Asclepias cornuti

Cercospora clavata (Ger.) Peck......................... 134

Glœosporium fusarioides E. \& K ..................... 100

Asparagus officinalis

Puccinia asparagi DeC.............................. 178

Rhizoctonia solani Kühn......................... 150

Aspidistra sp.

Colletotrichum omnivorum Halst....................... 108 Aster sp.

Coleosporium solidaginis (Schw.) Thüm.................. $16 z$

Avena sativa

Colletotrichum graminicolum (Cesati) Wilson............... 104

Puccinia coronata Cda.............................. 182

Ustilago avenæ (Pers.) Jens............................ 150

Ustilago levis (K. \& S.) Magn........................ 15?

Azalea viscosa

Synchytrium vaccinii Thomas........................ Begonia sp.

Glomerella cincta (B. \& C.) S. \& S...................... 52

Beta vulgaris $\mathrm{L}$.

Cercospora beticola Sacc.............................. $13 n$

Phoma betæ Rostr............................... 70

Betula nigra

Glcosporium betularum E. \& MF..................... 98

Bidens frondosa

Septocylindrium concomitans (E. \& H.) Hals................ 118

Brassica oleracea $\mathrm{L}$.

Alternaria brassicæ (Berk.) Sacc........................ 126

Peronospora parasitica (Pers.) de Bary.................... 16

Plasmodiophora brassicæ Wor........................ 6

Brassica rapa

Albugo candida (Pers.) Kuntze...................... $s$

Macrosporium herculeum E. \& M..................... 126

Peronospora parasitica (Pers.) de Bary.................... 16

Buxus sempervirens

Phyllosticta auerswaldii Allesch.......................... 62

Volutella buxi (Cda.) Berk............................. 144 
Calamigrostis camadensis

P.AGE

Sclerotium rhizodes Auer.......................... 1 .40

Calathea vitata

Glomerclla cincta $($ B. \& C.) S. \& S................... 53

Callistephus hortensis

Coleosporium soilidaginis (Schw.) Thü................. 162

Campanula sp.

Pliyllosticta alliariæfolix Allesch.......................

Campanula rapunculoides

Colcosporium campanulx (Pers.) Lev.................. 151)

Capsicum annum $\mathrm{L}$.

Colletotrichum nigrum E. \& H................... $10 \varepsilon$

Glcosporium piperatum E. \& E...................... 100

Sclerotium bataticola Taub.......................... 148

Cantaloupe (Cucumis melo)

Pseudoperonospora cubensis (B. \& C.) Rostew................. 14

Carex bullata

Puccinia sambuci (Schw.) Artlur....................... 189

Carex pallescens

Puccinia grossulariæ (Schum.) Lagerh.................... 184

Carya sp.

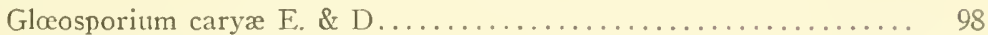

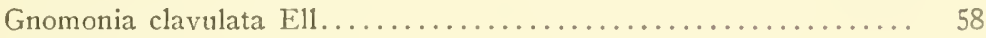

Castanea dentata

Endothia parasitica (Murr.) And....................... 60

Marssonia ochroleuca B. \& C........................ 110

Phyllosticta castaneæ E.\& E...................... 64

Cassandra calyculata

Synchytrium vaccinii Thomas........................ 6

Catalpa sp.

Phyllosticta catalpæ E. \& M..................... 64

Centaurea cyanus

Puccinia cyani (Schleich) Pass....................... 183

Cerastium vulgatum

Septoria cerastii Rob. \& Desm..................... s 8

Cercis canadensis

Cercospora cercidicola Ell............................ 132

Chætochloa viridis

Ustilago neglecta Niessl............................ 152

Chamaecyparis thyoides

Gymnosporangium botryapites (Schw.) Kern................ 168

Gymnosporangium ellisii (Berk.) Farlow................... 170

Gymnosporangium fraternum Kern................... 171

Chenopodiaceæ

Peronospora effusa (Grev.) Rabh..................... 16

Chenopodium album

Cercospora dubia (Riess) Wint.......................... 134

Chenopodium ambrosioides var. anthelminticum

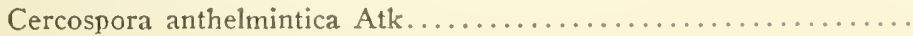


Chionanthus virginica

Cercospora chionanthi E. \& E........................ 132

Chrysanthemum sp.

Puccinia chrysanthemi Roze........................ 180

Septoria chrysanthemi Allesch........................ 88

Cirsium sp.

Cercospora obesa E. \& E........................... 140

Citrullus vulgaris

Cercospora citrullina Cke........................... 132

Colletotrichun lagenarium (Pass.) E. \& H................ 106

Citrus sp.

Colletotrichum glneosporioides Penz.................... 104

Claytonia virginica

Allodus claytoniata (Schw.) Arthur..................... 202

Clethra alnifolia

Phyllosticta clethricola C. \& M................... 64

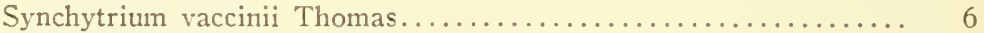

Cochlearia armoracea L.

Cercospora armoraceæ Sacc........................... 130

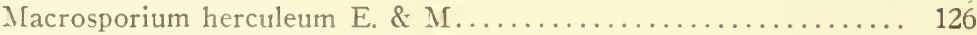

Peronospora parasitica (Pers.) de Bary.................... 10

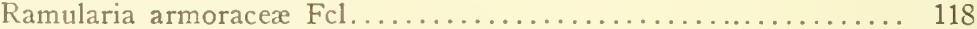

Rhizoctonia solani Kühn.......................... 150

Thielavia basicola (B. \& Br.) Zopf...................... 24

Coccidæ

Cordyceps clavulata Schw.......................... 38

Cocos plumosa

Glomerella cincta (B. \& C.) S. \& S.................. 52

Colutea aborescens

Phoma colutex S. \& R........................... 70

Compositæ

Albugo tragopogonis (De C.) S. F. Gray................. 8

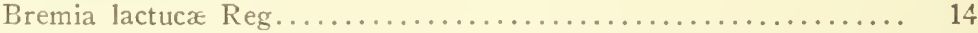

Erysiphe cichoracearum De C....................... 26

Comptonia sp.

Cronartium comptoniæ Arthur......................... 162

Convolvulaceæ

Albugo ipomeæ-panduranæ (Schw.) Swing................ 8

Convolvulus arvensis

Septoria convolvuli Desm......................... 88

Cornus sp.

Septoria cornicola Desm......................... 88

Cratægus sp.

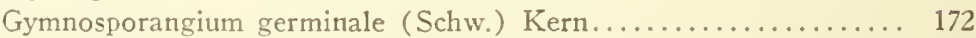

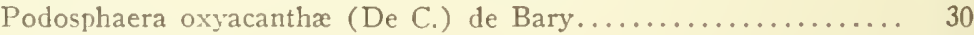

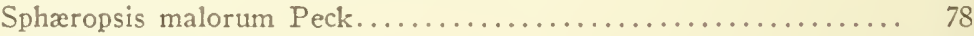

Cratægus oxyacantha

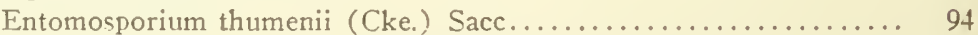


Cruciferze

Albugo candida (Pers.) Kuntze....................... 8

Alternaria brassicæ (Berk.) Sacc......................... 126

Macrosporium herculeum E. \& M..................... 126

Peronospora parasitica (Pers.) de Bary................... 16

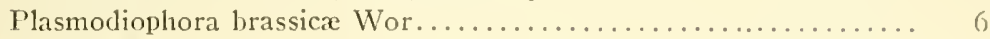

Curcurbitacce

Alternaria cucurbitx Let........................... 126

Pseudoperonospora cubensis (B. C.) Rost................... 14

Cucurbita maxima

Colletotrichum lagenarium (Pers.) E. \& H................. 106

Cucumis melo

Macrosporium cucumerinum E. \& E.................... 126

C.ucumis sativus $\mathrm{L}$.

Alternaria cucurbitx Let.......................... 126

Colletotrichum lagenarium (Pers.) E. \& H.................. 106

Macrosporium cucumerinum E. \& E................... 126

Pseudoperonospora cubensis (B. \& C.) Rost................... 14 Cumeria sp.

Glomerella cincta (B. \& C.) S. \& S................. 52

Cyclamen

Colletotrichum cyclamenæ Hals...................... 104

Cydonia japonica

Sphæropsis cydoniae C. \& E...................... 76

Cydonia vulgaris Pers.

Entomosporium maculatum Lev...................... 9f

Sphæropsis malorum Peck......................... is

Cyperus esculentus

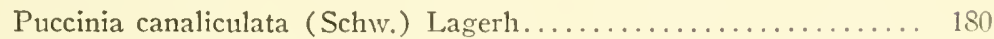

Dianthus caryophyllus L.

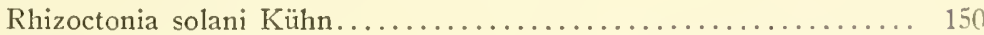

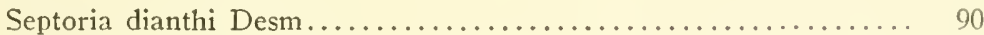

Sporotrichum poæ Peck............................. 116

Uromyces caryophyllinus (Schrank) Wint........................ 176

Diodea teres

Cercospora diodeæ Cke............................ 134

Nigredo spermacoces (Schw.) Arthur.............................

Dracæna sp.

Glœosporium polymorphum Tunchili.................... 100

Dracæna fragrans

Glœosporium polymorphum Tunchili................... 100

Dracæna sanderiana

Glomerella cincta (B. \& C.) S. \& S.................... 52

Dracæna terminalis

Glomerella cincta (B. \& C.) S. \& S.................... 52

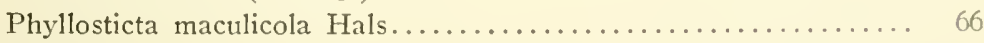

Drupacere

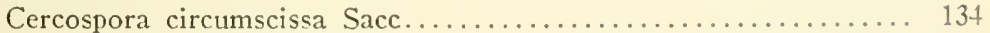

Phyllosticta circumscissa Cke....................... 64 
Fodosphaera oxyacanthæ (D. C.) de Bary................ 30

Sclerotinia fructigena (Pers.) Schr.................... 22 Elaphomyces

Cordyceps agariciformia (Bolt.) Seaver.................. 38

Erigeron sp.

Septoria erigerontis B. \& C....................... 90

Erigeron canadensis

Cercosporella cana (Pass.) Sacc....................... 120

Erythronium americanum

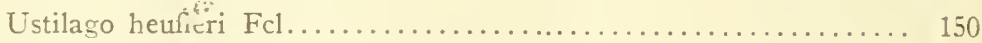

Eupatorium ageratoides

Cercospora ageratoides E. \& E....................... 128

Eupatorium album

Cercospora ageratoides E. \& E..................... 128

Euphorbia preslii

Nigredo prœminens (D. C.) Arthur................... 200

Ficus elastica

Glomerella cingulata (Atk.) S. \& S . . . . . . . . 52

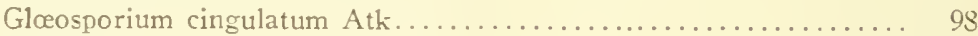

Fragaria sp.

Marssonia potentillæ (Desm.) Fisch. var fragariæ Sacc........... 112

Oidium fragarize Harz.............................. 116

Ramularia tulasnei Sacc............................ 120

Ganoderma tsugæ

Chromocrea ceramica (E. \& E.) Seaver................. 36

Gaultheria procumbens

Discosia maculicola Gerard .......................... 96

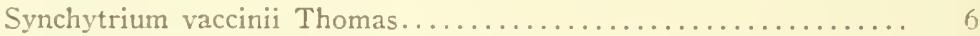

Venturia gaultheriæ E. \& E....................... 48

Gaylussacia sp.

Synchytrium vaccinii Thomas......................

Geranium carolinianum

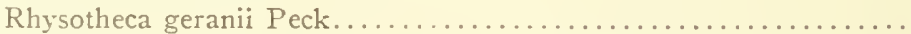

Graminaceæ

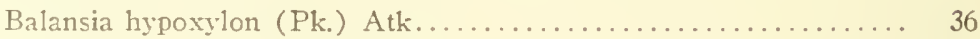

Phyllachora graminis (Pers.) Fcl.................... 42

Piricularia grisea (Cke.) Sacc....................... 120

Puccinia graminis Pers........................... 183

Typhodium typhinum (Pers.) Seaver.................. 38

Hedera helix

Phyllosticta concentrica Sacc........................... 64

Hedera helix

Colletotrichum hedericola Laub..................... 106

Helianthus annuus

Puccinia helianthi Schw............................ 185

Hemerocallis fulva

Heterosporium gracile (Wal.) Sacc.................... 124

Hibiscus moschatus var. crimsoni

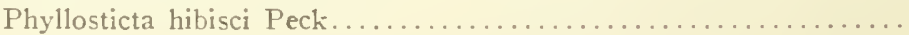


Hordeum sp.

Erysiphe graminis D. C.............................. 26

Ustilago hordei (Pers.) K. \& S........................ 150

Ustilago nuda (Jens.) K. \& S......................... 152

Iumulins lupulus

Sphærotheca humuli var. fuliginea (Schl.) Sal............... 32

Ilex glabra

Cercospora ilicis Ell.............................. 136

Impatiens biflora

Puccinia impatientis (Schw.) Arthur..................... 186 Insects

Cordyceps militaris (L.) Link......................... 40

Cordyceps sphingum (Schw.) B. \& C.................... 40

Ipomoea batatas

Albugo ipomoex-panduranæ (Schw.) Swing................ 8

Diaporthe batatatis Harter \& Field ...................... 60

Monilochaetes infuscans E. \& H...................... 120

Nectria ipomoeæ Hals.............................. 36

Penicillium luteum Znk.............................. 26

Phyllosticta bataticola E. \& M......................... 6!

Rhizopus batatas Nakazawa.......................... 18

Rhizopus nigricans Ehr........................... 18

Sclerotium bataticola Taub............................ 148

Sphæronema fimbriatum (E. \& H.) Sacc................... 72

Ipomoea hederacea

Albugo ipomoex-panduranæ (Schw.) Swing............... s

Coleosporium ipomoex (Schw.) Burr.................... 159

Ipomoea panduratx

Albugo ipomoeæ-panduranæ (Schw.) Swing................. Iris $\mathrm{sp.}$

Heterosporium gracile (Wal.) Sacc.................... $12+$ Juglans nigra

Marssonia juglandis (Lib.) Sacc......................... 110

Juncus tenuis

Cintractia junci (Schw.) Trel........................ 158

Juniperus stricta

Shæropsis juniperi Peck.......................... it

Juniperus virginiana

Gymnosporangium effusum Kern.................... 170

Gymnosporangium germinale (Schw.) Kern............... 17z

Gymnosporangium globsum Farl.................... 17 가

Gymnosporangium juniperi-virginianæ Schw.............. 171

Kalmia angustifolia

Synchytrium vaccinii Thomas.........................

Kentia fosteriana

Colletotrichum kentiæ Hals.......................... In,

Kerria japonica

Phoma japonica Sacc. 
Koellia virginiana

PAGE

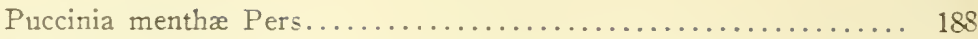

Lathyrus odoratus

Thielaria basicola (B. \& Br.) Zopf...................... 24

Lactuca sativa L.

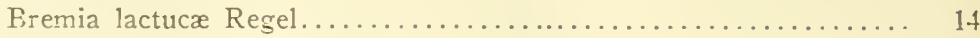

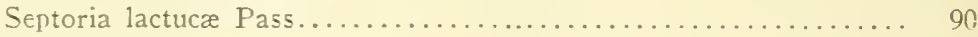

Lepidium sp.

Peronospora lepidii (McAlp.) Irilson................... 16

Liquidambar styraciflua

Septoria liquidambaris C. \& E..................... 90

Lobelia inflata

Septoria lobelix Peck.............................. 90

Magnolia sp.

Coniothyrium olivaceum Bon. var. grandifloræ Sacc........... 80

Magnolia glauca

Cercospora magnolix E. \& Hark........................ 136

Malvaceæ

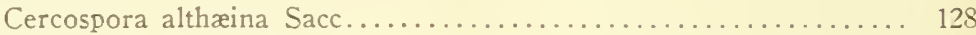

Malva sp.

Cercospora althæina Sacc........................... 128

Puccinia malvacearum Mont......................... 188

Medicago sativa $\mathrm{L}$.

Cercospora medicaginis E. \& E...................... 138

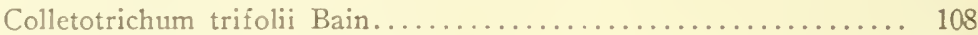

Pleospora hyalospora E. \& E........................ 46

Pseudopeziza medicaginis (Lib.) Sacc................... 22

Rhizoctonia solani Kühn........................... 150

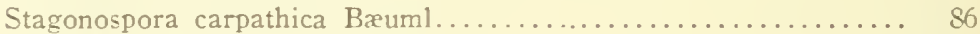

Thielaria basicola (B. \& Br.) Zopf...................... 24

Meibomia

Ramularia desmodii Cke.......................... 118

Melilotus officinalis

Ascochyta lethalis E. \& B........................ 82

Morus sp.

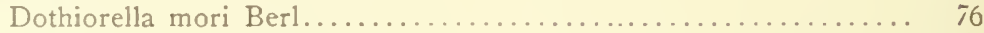

Nectria cinnabarina (Tode.) Fr...................... 34

Sphæropsis mori Berl............................... 76

Musa sapientum

Glœosporium musarum Cke. \& Mass.................... 100

Musca domestica

Saprolegnia ferax (Gruith) Thuret.................... 6

Myrica carolinensis

Gymnosporangium Ellisii (Berk.) Farlow................. 170

Myrica cerifera

Septoria myricæ E. \& $\mathbb{W}^{\top} \ldots \ldots \ldots \ldots \ldots \ldots \ldots \ldots \ldots \ldots \ldots \ldots \ldots . \ldots \ldots$

Nabalus albus

Septoria nabali B. \& C............................ 92 
Nymphæa advena

Phyllosticta orontii E. \& M. var adiena............... 68

Oenothera biennis

Nigredo plumbaria (Pk.) Arthır..................... 19,1

Oxycoccus macrocarpus

Acanthorynchus vaccinii Shear................... +2

Glomerella rufomaculans vaccinii Shear............... 50

Guignardia vaccinii Shear........................

Pestalozzia gucpini Desm. var. vaccinii Shear................ 112

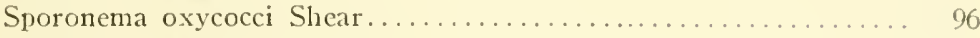

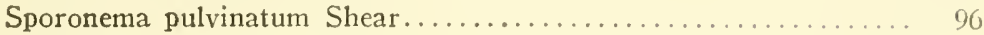

Synchytrium vaccinii Thomas........................ 6

Panicum capillare

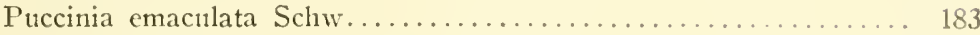

Panicum proliferum

Sorosporium syntherismæ (Peck.) Farl,................... 156

Ustilago pustulata T. \& E.......................... 154

Pastinaca sativa

Cercospora apii Fr............................. 130

Phaseolus lunatus

Phoma subcircinata E. \& E..................... T?

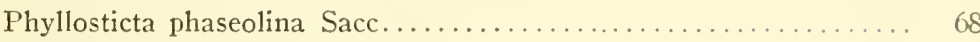

Phytophthora phaseoli Thaxter.......................... 10

Uromyces appendiculatus (Pers.) Lev................... 175

Phaseolus vulgaris $\mathrm{L}$.

Cercospora canescens E. \& M...................... 132

Cercospora cruenta Sacc................................ 134

Colletotrichum lindemuthianum (Sacc. \& Mag.) B. \& C........... 106

Pisum sp.

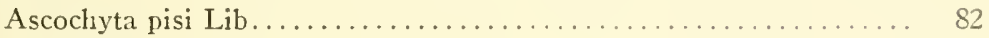

Phlox subulata

Puccinia douglasii E. \& E. . . . . . . . . . . . . . . . . . . . 183

Physalis virginiana

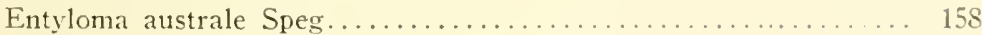

Pinus sp.

Diplodia pinea (Desm.) Kickx...................... \$ $\$ 6$

Lophodermium pinastri (Schr.) Chev..................... 24

Peridermium acicolum Underw. \& Earle.................. 160

Peridermium pyriforme Peck........................ 162

Pinus excelsa

Lophodermium brachysporum Rost.................. 24

Pinus rigida

Periderminm acicolum Underw. \& Earle.................. 160

Peridermium rostrupi E. Fischer..................... 164

Pinus strobus

Peridermium strobi Kleb........................ 163

Pinus sylvestris

Diplodia sapinea $($ Fr. $)$ Fckl....................... \&6 
Plantaginaceæ

PAGE

Peronospora effusa (Grev.) Rab..................... 16

Plantago lanceolata

Phoma polygramma (Fr.) Sacc. var. plantaginis Sacc........... 72

Ramularia plantaginis E. \& M........................ 118

Platanus sp.

Coniothyrium platani Sacc........................ 80

Platanus occidentalis

Glœosporium nervisequum (Fcl.) Sacc.................. 100

Podophyllum peltatum

Allodus podophylli (Schw.) Arthur..................... 202

Polygonum sp.

Nigredo polygoni (Pers.) Arthur........................ 196

Septoria polygonorum Desm.......................... 92

Polygonum aviculare

Vermicularia dematium (Pers.) Fr.................... 74

Polygonum cilinode

Ustilago anomala J. Kunze.......................... 150

Polygonum pennsylianicum

Melanopsichium austro-americanum (Speg.) G. Beck............ 155

Ustilago utriculosa (Nees.) Tul...................... 155

Pomaceæ

Podosphaera oxyacantha (D. C.) de Bary............... 30

Populus sp.

Marssonia populi (Lib.) Sacc......................... 112

Taphrina aurea (Pers.) Fries....................... 20

Populus candicans

Marssonia brunea (E. \& E.) Sacc...................... 110

Populus deltoides

Dothichiza populea Sacc. \& Br..................... 96

Melamspora medusæ (Thüm) Arthur................. I6n

Populus grandidentata

Marssonia rhabdospora E. \& E..................... 112

Populus italica

Dothichiza populea Sacc. \& Br..................... 96

Portulaca oleracea

Albugo portulacæ (D. C.) Kuntze.................... \&

Potentilla sp.

Rhysotheca potentillæe de Bary

Potentilla canadensis

Phragmidium obtusa (Strass.) Arthur.................. 166

Potentilla monspeliensis

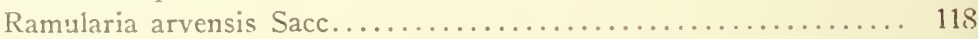

Primula sp.

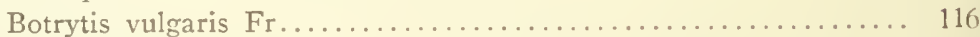

Prunella vulgaris

Septoria prunellæ Ell. \& Holw........................ 92 
Prunus sp.

PA, E

Cercospora circumscissa Sacc........................ 134

Cylindrosporium padi Karst ....................... 114

Phyllosticta circumscissa Cke......................

Plowrightia morbosa (Schw.) Sacc.................... 40

Podosphaera oxyacanthe (D. C.) de Bary................ 30

Sclerotinia fructigena (Pers.) Schr.................... 22

Taphrina cerasi (Fck.) Sad......................... 20

Taphrina pruni $(\mathrm{Fcl}.) \mathrm{Tul} \ldots \ldots \ldots \ldots \ldots \ldots \ldots \ldots \ldots \ldots \ldots . \ldots . \ldots . \ldots 20$

Prunus persica Benth. \& Hook.

Cercospora circumscissa Sacc........................ 134

Cladosporium carpophilum Thüm...................... 122

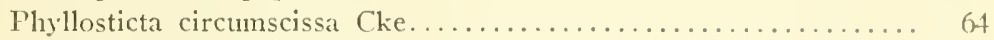

Sclerotinia fructigena (Pers.) Schr..................... 22

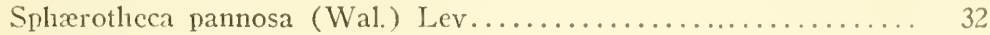

Taphrina deformans $(\mathrm{Fcl}$.$) Tul...................... 20$

Pyrus communis L.

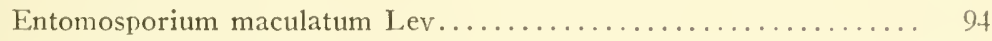

Mycosphærella sentina (Fr.) Schr..................... 46

Phoma mali Schulz \& Sacc.......................... 70

Sphæropsis malorum Peck........................ is

Pyrus malus L.

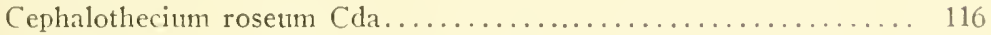

Glomerella rufomaculans (Berk.) S. \& S................ 50

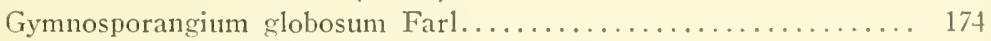

Gymnosporangium juniperi-virginianæ Schw............. 171

Monochætia mali (E. \& E.) Sacc...................... 112

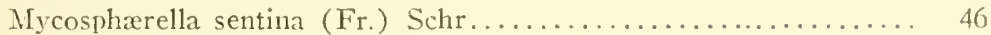

Phoma mali Schulz \& Sacc......................... 70

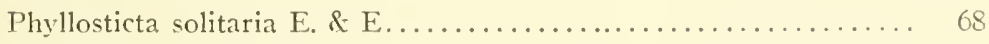

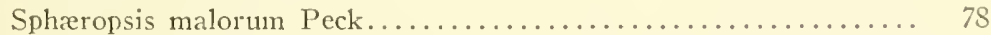

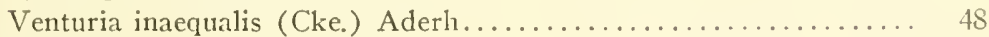

Quercus sp.

Diplodia longispora C. \& E...................... \&4

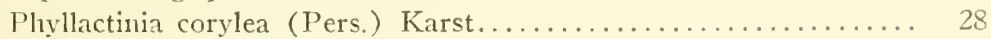

Taphrina coerulescens (D. \& M.) Tul.................. 20

Quercus alba

Marssonia martini Sacc. \& Ell. . . . . . . . . . . . . . . 110

Quercus nigra

Gnomonia clavulata Ell............................. 58

Raphanus sativus $\mathbf{L}$.

Albugo candida (Pers.) Kuntze...................... $s$

Peronospora parasitica (Pers.) de Bary................... 16

Reseda odorta

Cercospora resedæ $\mathrm{Fcl} \ldots \ldots \ldots \ldots \ldots \ldots \ldots \ldots \ldots \ldots \ldots . \ldots \ldots$

Rhododendron sp.

Pestalozzia guepini Desm......................... 112

Rheum rhaponticum

Ascochyta rhei E. \& E. 
Rhus sp.

Cylindrosporium toxicodendri (Curtis) Dearness.............. 114

Rhus copallina

Cercospora rhuina C. \& E.......................... 140

Septoria rhoina B. \& C............................ 94

Rhus glabra

Cercospora rhuina C. \& E......................... 140

Rhus toxicodendron

Cylindrosporium toxicondendri (Curtis) Dearness.............. 114 Ribes sp.

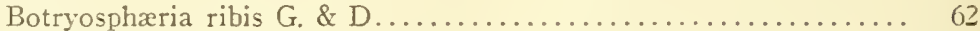

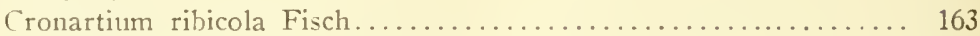

Glœosporium ribis (Lib.) M. \& D........................ 102

Nectria cinnabarina (Tode) Fr........................ 34

Ribes grossularia L.

Glœosporium ribis (Lib.) M. \& D...................... 102

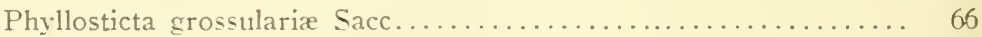

Rosa sp.

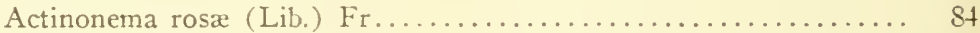

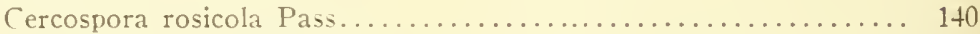

Coniothyrium fuckelii Sacc....................... s0

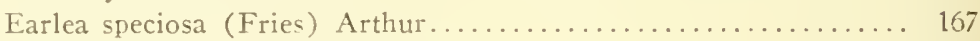

Glomerella cincta (B. \& C.) S. \& S.................... 52

Mycosphærella rosigena E. \& E..................... 4

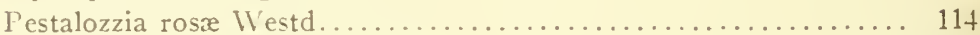

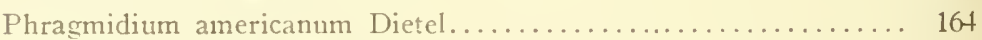

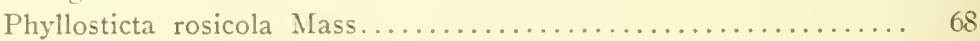

Sphærotheca pannosa (Wal.) Lev.................... 32

Rubus sp.

Cæoma nitens Schw............................. 193

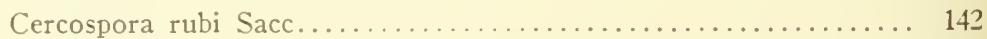

Coniothyrium fuckelii Sacc........................ 80

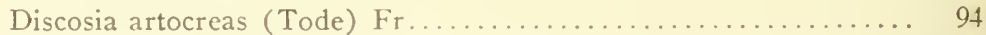

Fusarium rubi WVint............................. $1+6$

Glœosporium venetum Speg.......................... 102

Glomerella rubicola (Ston.) S. \& S................... 52

Kuehneola uredinis (Link) Arthur................... 167

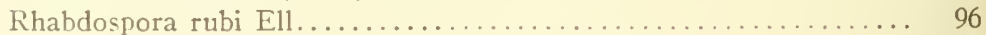

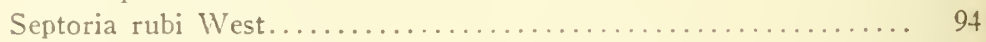

Sphæropsis rubicola C. \& E....................... 76

Rubus canadensis

Cercospora rubi Sacc............................. 142

Rubus fructicosa

Cercospora rubi Sacc........................... 142

Rubus occidentalis
Gløosporium venetum Sper $\ldots \ldots \ldots \ldots \ldots \ldots$
102 Salix sp.

Gloeosporium salicis $V^{r}$ est......................... 102 
Tragopogon porrifolius L.

PAGE

Albugo tragopogonis (D. C.) S. F. Gray................. \&

Saponaria officinalis

Phyllosticta tenerrima E. \& E...................... 70

Secale cereale

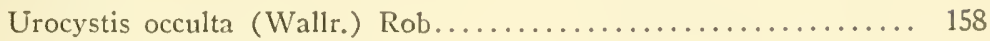

Capsella bursa pastoris

Albugo candida (Pers.) Kuntze...................... 8

Sicyos angulatus

Rhysotheca australis (Speg.) Wilson.................. 10

Smilax sp.

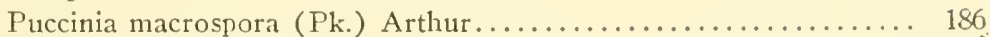

Puccinia smilacis Schw.............................. 190

Smilacina racemosa

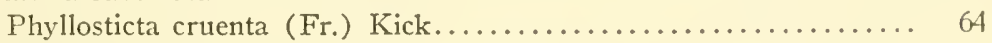

Solanum melongena $\mathrm{L}$.

Phomopsis vexans (Sacc. \& Syd.) Harter................... 74

Solanum tuberosum L.

Alternaria solani (E. \& M.) Jones \& Grout................. 126

Phytophthora infestans (Mont.) de Bary................. 10

Rhizoctonia solani Kühn........................ 150

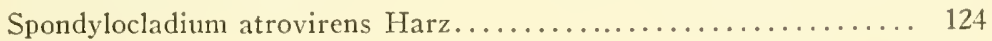

Solidago sp.

Coleosporium solidaginis (Schw.) Thüm................. 162

Spinacia oleracea Mill

Peronospora effusa (Grev.) Rab....................... 16

Staphylea trifolia

Sphæropsis staphylex Brun.......................... 76

Symplocarpus fotidus

Cercospora symplocarpi Peck......................... 142

Syntherisma sanguinalis

Ustilago rabenhorstiana Kühn...................... 154

Syringa vulgaris L.

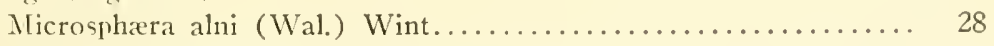

Phyllosticta halstedii E. \& E......................... 66

Sphæropsis syringæ (Fr.) Peck \& Cke.................. 78

Taraxacum sp.

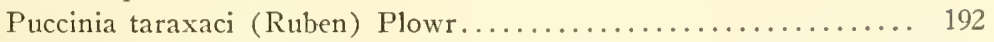

Ramularia taraxaci Karst........................ 120

Thalictrum sp.

Polythelis thalictri (Chev.) Arthur..................... 164

Tilia sp.

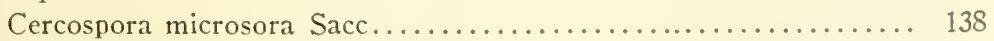

Tilia americana

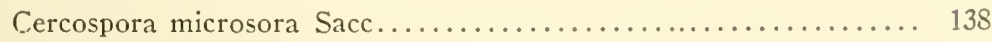

Tilia Europea

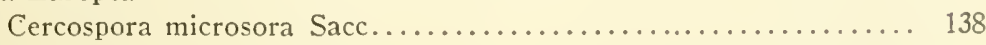


Tomato (Lycopersicum esculentum Mill)

PAGE

Alternaria solani (E. \& M.) Jones \& Grout.................... 126

Ascochyta lycopersici Brun............................ 82

Cladosporium fulvum Cke........................... 122

Colletotrichum phomoides (Sacc.) Ches.................... 108

Fusarium lycopersici Sacc............................ 146

Rhizoctonia solani Kühn............................ 150

Septoria lycopersici Speg........................... 90

Trifolium sp.

Colletotrichum trifolii Bain........................... 108

Polythrincium trifolii Kuntze.......................... 122

Pseudopeziza trifolii (Pers.) Fckl....................... 22

Trifolium incarnatum

Cercospora medicaginis E. \& E.......................... 138

Trifolitum pratense

Cercospora medicaginis E. \& E......................... 138

Gloosporium caulivorum Kirch......................... 98

Nigredo fallens (Desmaz.) Arthur........................ 194

Trifolium repens

Nigredo trifolii (Hedw.) Arthur......................... 198

Stagonospora carpathica Baeuml....................... 86

Tripsacum dactyloides

Puccinia polysora Underwood........................... 189

Triticum sp.

Cladosporium herbarum (Pers.) Lk..................... 122

Erysiphe graminis D. C............................. 26

Puccinia graminis Pers............................... 183

Puccinia triticina Eriks............................... 192

Tilletia fœtens (B. \& C.) Trel........................... 156

Tilletia tritici (Bjerk.) Wint.......................... 156

Ustilago tritici (Pers.) Rostr........................... 154

Tulipa gesneriana

Botrytis parasitica Cav............................... 116

Uredinia

Darluca filum (Biv.) Cast............................ 84

Tuberculina persicina (Ditm.) Sacc..................... 144

Vaccinium corymbosum

Synchytrium vaccinii Thomas......................... 6

Verbascum blattaria

Septoria verbasicola B. \& C............................ 94

Verbascum thapsus

Phoma thapsi E. \& E............................. 72

Vicia sp.

Ascochyta viciæ Lib............................... 84

Viburnum lantana

Rhysotheca viburni (Pk.) Wilson.................... 12

Vigna sinensis

Cercospora cruenta Sacc............................... 134

Cercospora dolichii E. \& E............................ 134 
Viola sp.

PAGE

Cercospora granuliformis Ell. \& Holw.................... 136

Cercospora violæ Sacc............................. 142

Phyllosticta violæ Desm.............................. 70

Viola tricolor

Colletotrichum violæ-tricoloris R. E. Smith ................ 108

Phyllosticta violæ Desm.............................. 70

Vitis sp.

Fusicoccum viticolum Reddick...................... 74

Gloosporium ampelophagum (Pass.) Sacc................. 96

Guignardia bidwelli (E.) V. \& R...................... 44

Isariopsis clavispora (B. \& C.) Sacc...................... 144

Melanconium fuligineum (S. \& V.) Car.................. 110

Rhysotheca viticola (B. \& C.) Wilson.................... 12

Uncinula necator (Schw.) Burr....................... 32

Xanthium sp.

Puccinia xanthii Schw.............................. 193

Yucca sp.

Coniothyrium concentricum (Desm.) Sacc................. 80

Zea Mays L.

Helminthosporium inconspicuum C. \& E. ................. 122

Puccinia sorghi Schw................................ 190

Ustilago zex (Beck.) Ung............................ 155 



\section{FUNGUS INDEX}

Acanthorynchus vaccinii Shear....................... $\$ 2$

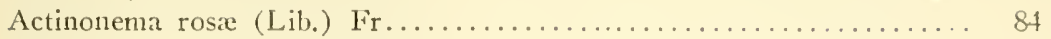

Albugo bliti (Biv.) Kuntze............................. 6

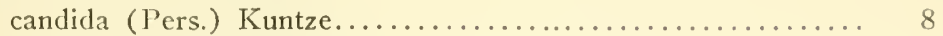

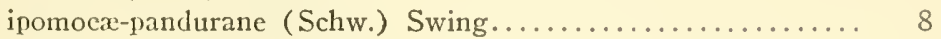

portulacx (D. C.) Kuntze...................... 8

tragopogonis (D. C.) S. F. Gray..................... 8

Allodus claytoniata (Schw.) Arthur....................... 202

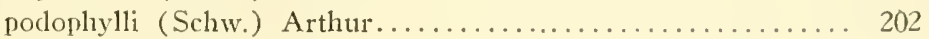

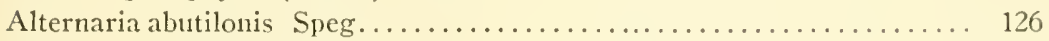

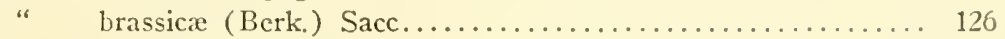

" cucurbitx Let.............................. 126

“ solani (E. \& M.) Jones \& Grout..................... 126

Ascochyta althæina Sacc. \& Bizz........................ 82

" lethalis E. \& B........................... 82

" lycopersici Brun............................ 82

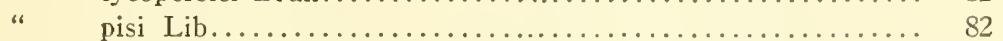

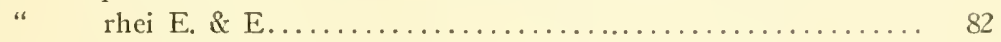

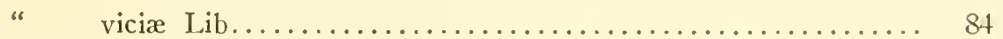

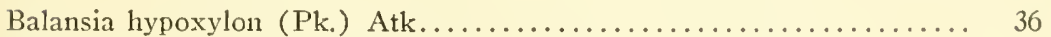

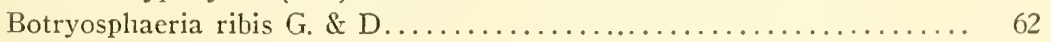

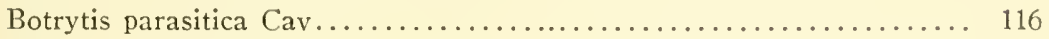

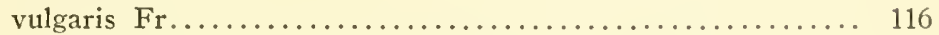

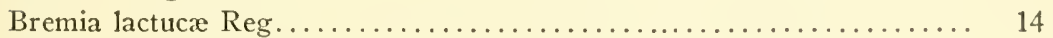

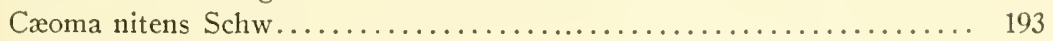

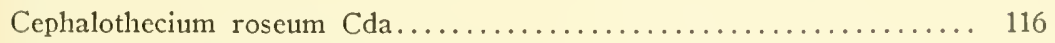

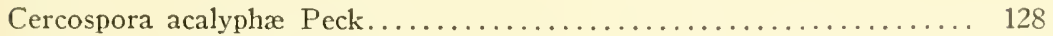

ageratoides E. \& E........................... 128

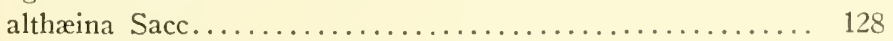

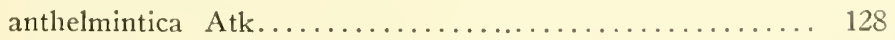

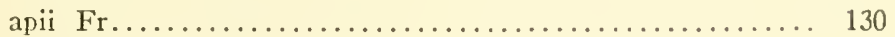

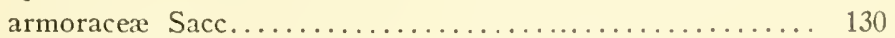

beticola Sacc................................ 130

canescens E. \& M.......................... 132

cercidicola Ell................................ 132

chionanthi E. \& E........................... 132

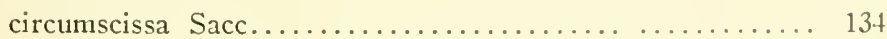

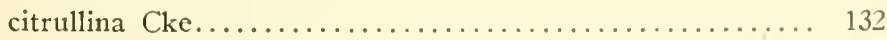

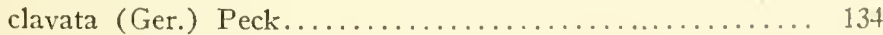

cruenta Sacc.................................. 134

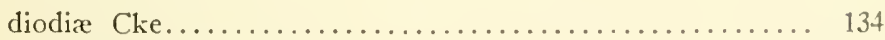

dolichii E. \& E.............................. 134

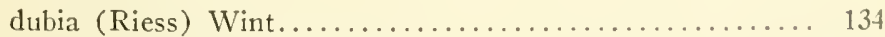

granuliformis Ell. \& Holw........................ 136

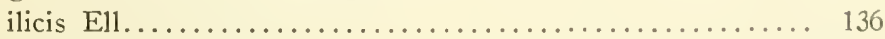

magnoliæ E. \& Hark....................... 136 
PAGE

Cercospora medicaginis E. \& E..................... 138

" microsora Sacc............................ 138

“ obesa E. \& E.............................. 140

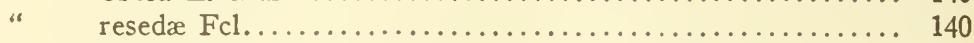

" rhuina C. \& E.................................... 140

" rosicola Pass............................... 140

“ rubi Sacc............................... 142

" symplocarpi Peck........................... 142

" violæ Sacc.............................. 142

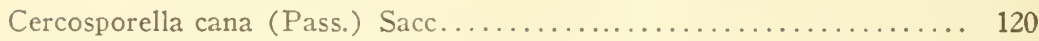

Chromocrea ceramica (E. \& E.) Seaver.................... 36

Cintractia junci (Schw.) Trel......................... 158

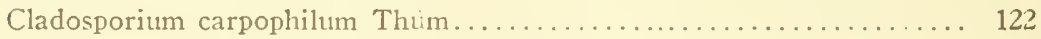

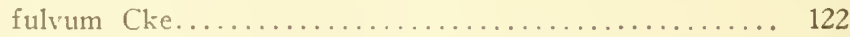

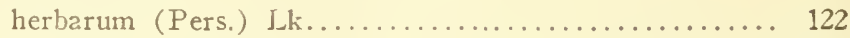

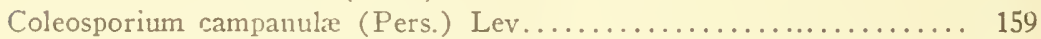

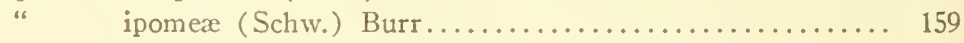

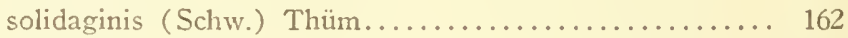

Colletotrichum antirrhini Stewart....................... 102

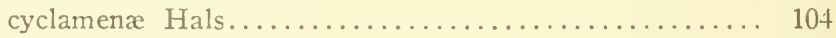

gloosporioides Penz........................ 104

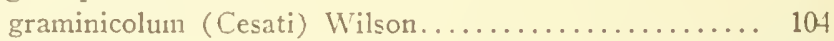

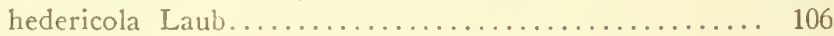

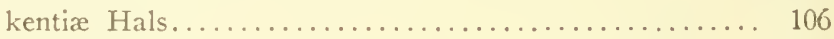

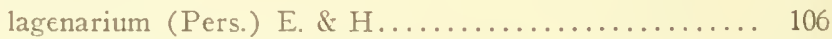

lindemuthianum (Sacc. \& Mg.) B. \& C............. 106

nigrum E. \& H........................ 108

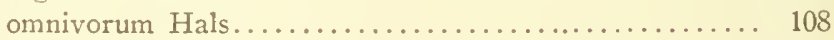

phomoides (Sacc.) Ches....................... 108

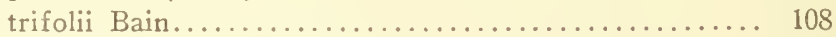

violæ-tricoloris R. E. Smith.................. 108

Coniothyritum concentricum (Desm.) Sacc................... 80

" fuckelii Sacc........................... 80

" olivaceum Bon. var. grandiflore Sacc............. 80

" platani Sacc............................ 80

Cordyceps agariciformia (Bolt.) Seaver.................... 38

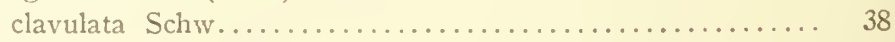

militaris (L.) Link........................ 40

sphingum (Schw.) B. \& C . . . . . . . . . . . . . . . . 40

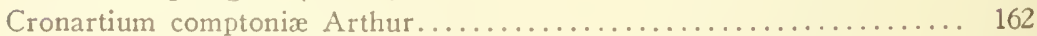

" ribicola Fisch............................ 163

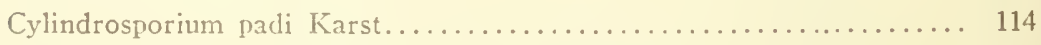

toxicodendri (Curtis) Dearness............... 114

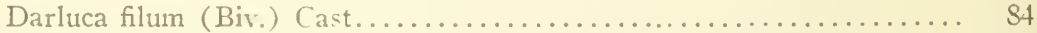

Diaporthe batatatis Harter \& Field....................... 60

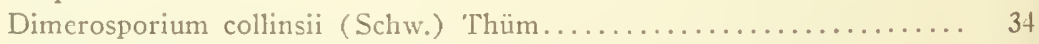

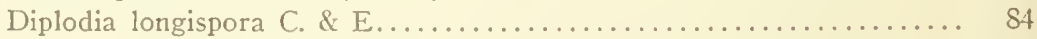

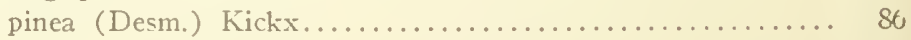

" sapinea (Fr.) Fckl........................ 86 
Discosia artocreas (Tode) Fr................................ 94

" maculicola Gerard............................... $9 x^{\prime}$

Dothichiza populea Sacc, \& Br.......................... 96

Dothiorella mori Berl.............................. 76

Earlea speciosa (Fries) Arthur.............................. 167

Endothia parasitica (Murr.). And.......................... 60

Entomosporium maculatum Lev.......................... 94

" thumenii (Cke.) Sacc........................ 94

Entyloma australe Speg.................................... 158

Erysiphe cichoracearum D. C........................... 26

graminis D. C................................ 26

Fusarium lycopersici Sacc............................. 146

rubi Winter................................... 146

Fusicoccum viticolum Reddick.......................... 74

Gloxosporium ampelophagnum (Pass.) Sacc................. 96

betularum E. \& M........................... 98

caryæ E. \& D.............................. 98

caulivorum Kirch......................... 98

cingulatum Atk............................ 98

fusarioides E. \& K........................... 100

musarum Cke. \& Mass........................... 100

nervisequum (Fcl.) Sacc..................... 100

piperatum E. \& E......................... 100

polymorphum Tunchili...................... 100

ribis (Lib.) M. \& D......................... 102

rufomaculans (Berk.) Thüm................... 102

salicis West............................... 102

venetum Speg................................. 102

Glomerella cincta (B. \& C.) S. \& S......................... 52

" cingulata (Atk.) S. \& S........................ 52

" rubicola (Ston.) S. '\& S.......................... 52

" rufomaculans (Berk.) S. \& S.................... 50

" rufomaculans vaccinii Shear..................... 50

Gnomonia andropogonis E. \& E....................... 58

" clavulata Ell.................................. 58

Guignardia æsculi (Pk.) V. B. Stewart....................... 42

" bidwelli (E.) V. \& R....................... 4

" vaccinii Shear.............................. 4

Gymnosporangium botryapites (Schw.) Kern.................. 168

" effusum Kern........................... 170

“ ellisii (Berk.) Farlow.................... 170

" fraternum Kern........................ 171

" globosum Farl.......................... 174

" germinale (Schw.) Kern.................. 172

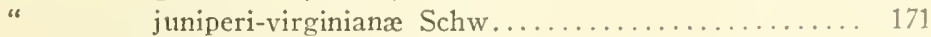

"transformans (Ellis) Kern................ 175

Helminthosporium inconspicuum C. \& E.................... 122

Heterosporium gracile (Wal.) Sacc.......................... 124 
Isariopsis clavispora (B. \& C.) Sacc.................... 144

Kuehneola uredinis (Link.) Arthur..................... 167

Lophodermium brachysporum Rost..................... 24

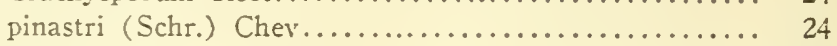

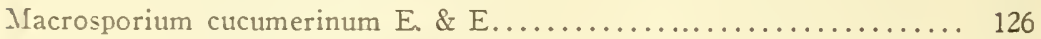

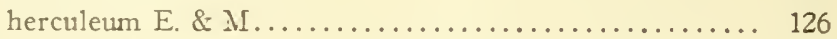

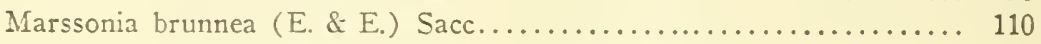

" juglandis (Lib.) Sacc......................... 110

" martini Sacc. \& Ell.......................... 110

" ochroleuca B. \& C........................... 110

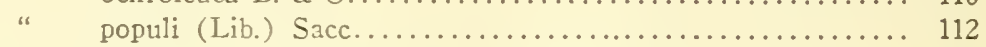

“ potentillæ (Desm.) Fisch. var. fragariæ Sacc............. 112

" rhabdospora E. \& E.......................... 112

Melanconium fuligineum (S. \& V.) Car.................... 110

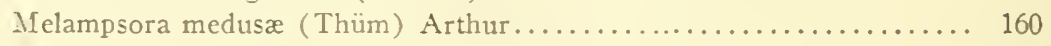

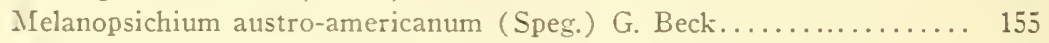

Microsphæra alni (Wal.) Wint........................ 28

Monilochætes infuscans E. \& H........................ 120

Monochætia mali (E. \& E.) Sacc........................ 112

Mycosphærella rosigena E. \& E....................... 4

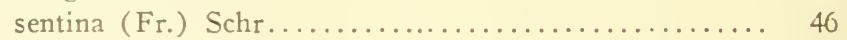

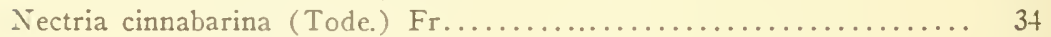

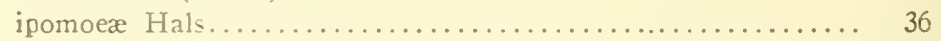

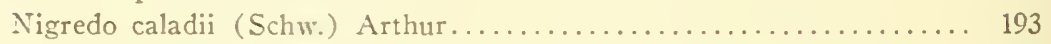

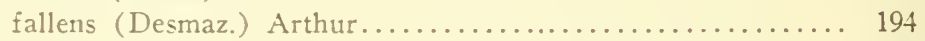

plumbaria (Pk.) Arthur.......................... 194

polygoni (Pers.) Arthur......................... 196

prœminens (D. C.) Arthur....................... 200

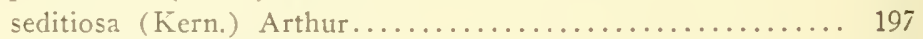

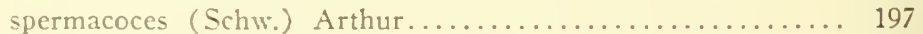

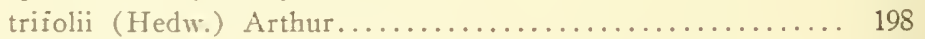

Cidium fragarix Harz............................. 116

Penicillium luteum Zuk............................. 26

Peridermium acicolum Lnderw. \& Earle..................... 160

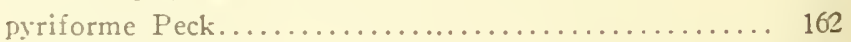

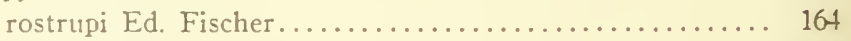

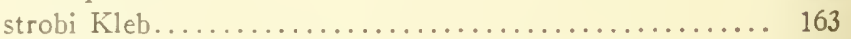

Peronospora parasitica (Pers.) de Bary..................... 16

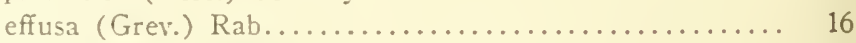

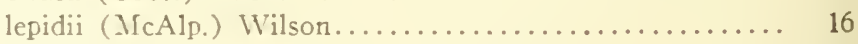

Pestalozzia guepini Desm........................... 112

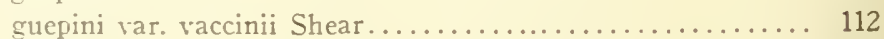

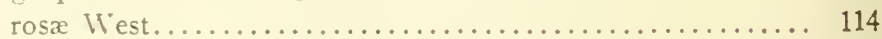

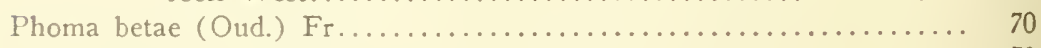

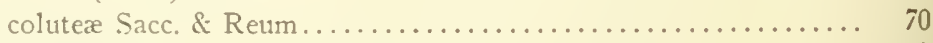

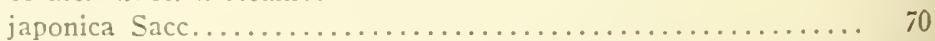

mali Schulz \& Sacc............................. 70

polygramma (Fr.) Sacc. var. plantaginis Sacc............. 72 
PAGE

I'homa subcircirata E. \& E............................. 72

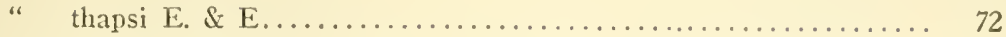

Phomopsis vexans (Sacc. \& Syd.) Harter..................... 74

Phragmidium americanum Dietel.......................... 164

obtusa (Strass.) Arthur....................... 166

Phyllachora graminis (Pers.) Fcl....................... 42

trifolii (Pers.) Fcl........................ 42

Phyllactinia corylea (Pers.) Karst......................... 28

Phyllosticta acericola C. \& E.............................. 62

alliarixfolix Allesch......................... 62

ampelopsidis E. \& M.......................... 62

aristolochi:e F. Tassi........................... 62

auerswaldii Allesch............................ 62

bataticola E. \& M[............................. 64

castaneæ E. \& E................................ 64

catalpæ E. \& M.................................. 64

circumscissa Cke........................... 64

clethricola C. \& M............................. 64

concentrica Sacc............................. 6.4

cruenta (Fr.) Kick.............................. 64

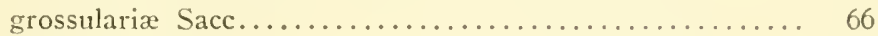

halstedii E. \& E.............................. 66

hibisci Peck................................. 66

maculicola Hals.............................. 66

orontii E. \& M. var. advena...................... 68

phaseolina Sacc.............................. 68

rosicola Mass............................... 68

solitaria E. \& E............................... 68

tenerrima E. \& E........................... 70

violæ Desm.................................. 70

Phytophthora infestans (Mont.) de Bary..................... 10

phaseoli Thaxter............................ 10

Piricularia grisea (Cke.) Sacc............................. 120

Plasmodiophora brassicæ Wor............................ 6

Pleospora hyalospora E. \& E........................... 46

Plowrightia morbosa (Schw.) Sacc......................... 40

Podosphæra oxyacanthæ (D. C.) de Bary..................... 30

Polythelis thalictri (Chev.) Arthur......................... $16 t$

Polythrincium trifolii Kuntze........................... 122

Pseudoperonospora cubensis (B. \& C.) Rost................... 14

Pseudopeziza medicaginis (Lib.) Sacc....................... 22

trifolii (Pers.) Fckl........................ 22

Puccinia antirrhini Dietel \& Holw ........................ 178

asparagi D. C.................................. 178

canaliculata (Schw.) Lagerh......................... 180

chrysanthemi Roze............................... 180

coronata Cda................................. 182

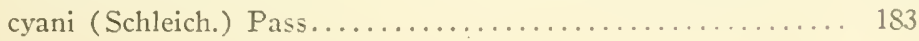




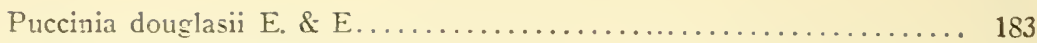

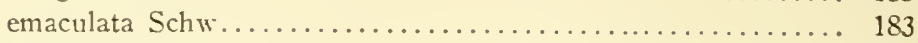

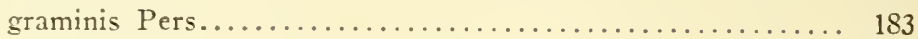

grossulariæ (Schum.) Lagerh..................... 184

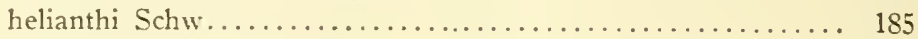

impatientis (Schw.) Arthi1 ................... 186

macrospora (Pk.) Arthur..................... 186

malvacearum Mont........................ 188

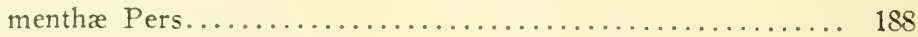

polysora Underwood......................... 189.

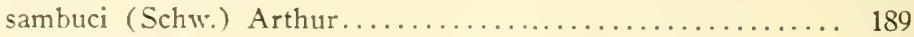

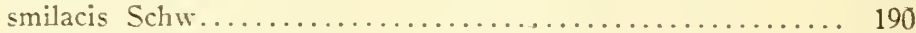

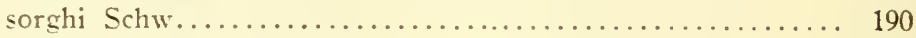

taraxaci (Ruben) Plowr......................... 192

triticina Eriks............................ 192

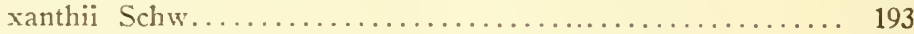

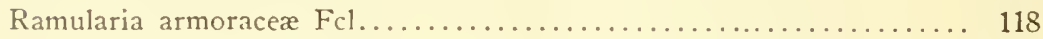

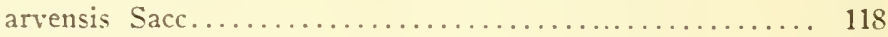

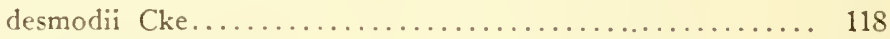

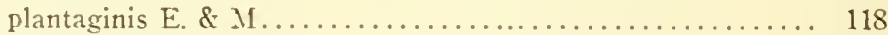

taraxaci Karst........................... 120

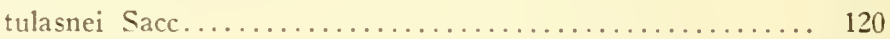

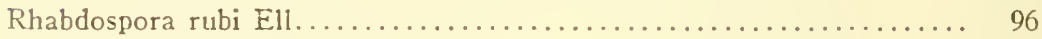

Rlizoctonia solani Kühn........................... 150

Rhizopus batatas Nakazawa............................ 18

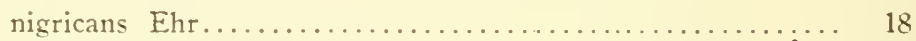

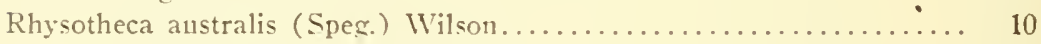

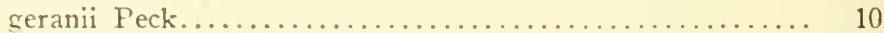

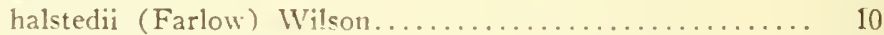

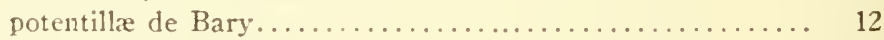

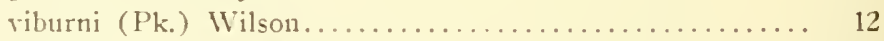

viticola (B. \& C.) Wilson ..................... 12

Rhytisma acerinum (Pers.) Fr....................... 24

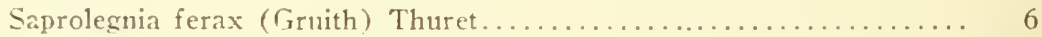

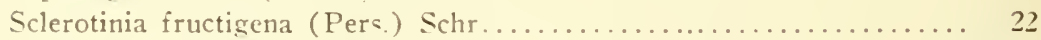

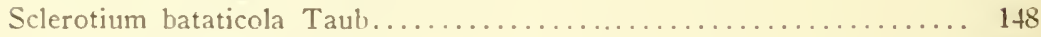

rhizodes Auersw........................... 146

Septocylindrium aromaticum Sacc...................... 118

concomitans (E11. \& Hals.) Hals................ 118

Septoria cerastii Roh. \& Desm......................... \& 8

chrysanthemi Allesch.......................... 88

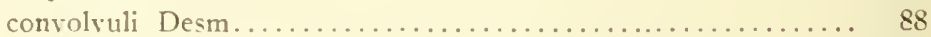

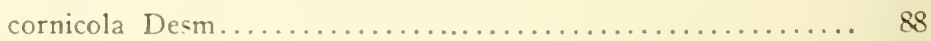

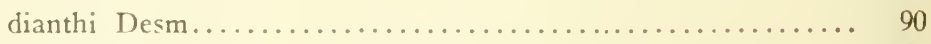

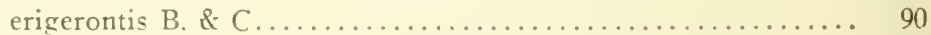

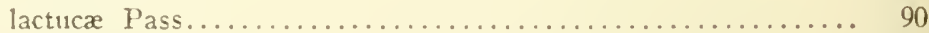

liquidambaris C. \& E.......................... 90

“ lobeliæ Peck.................................. 90 
PAGE

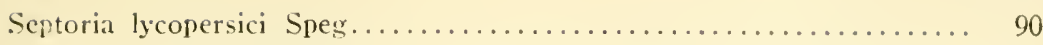

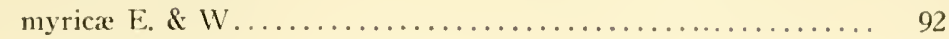

nabali B. \& C.............................. 92.

petroselini Desm. var. apii Br. \& Cav................ 92

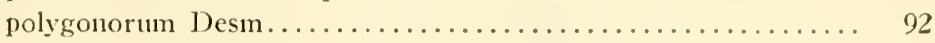

prunella Ell. \& Holw.......................... 92

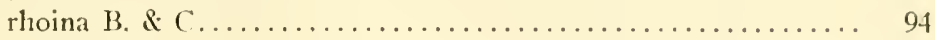

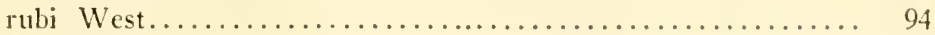

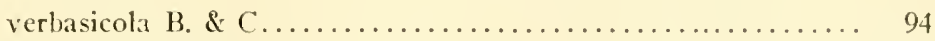

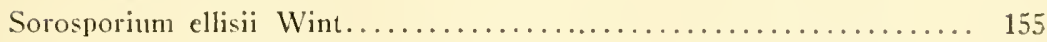

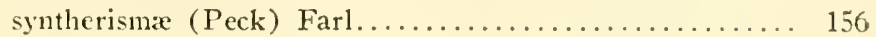

Spharopsis cydonize C. \& E......................... 76

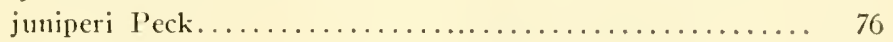

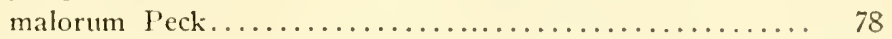

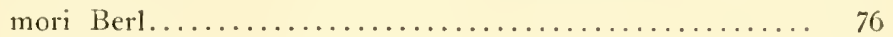

rubicola C. \& E............................ 76

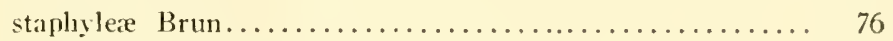

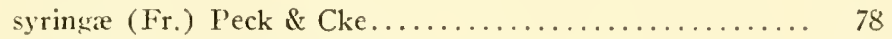

Sphæronenı fimliriatım (E. \& H.) Sacc.................. 72

Sphærotheca humuli var. fuliginea (Schl.) Sal................. 32

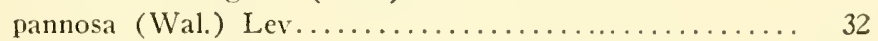

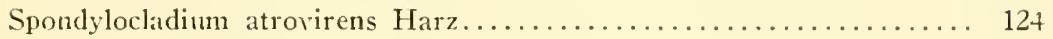

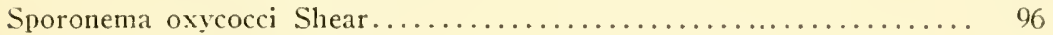

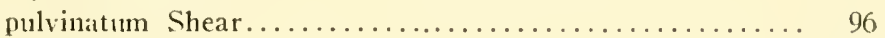

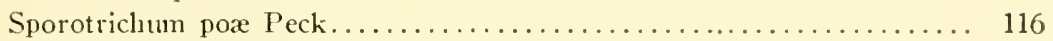

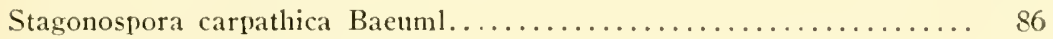

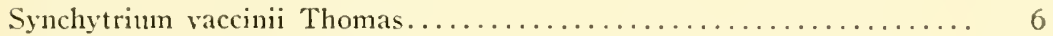

Taplirina aurea (Pers.) Fries.......................... 20

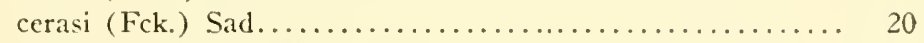

coerulescens (D. \& M.) Tul.................... 20

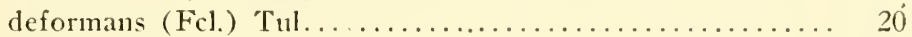

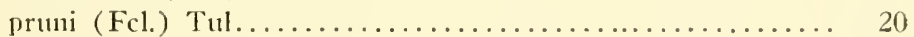

Thielaria basicola (B. \& Br.) Zopf........................ $2+$

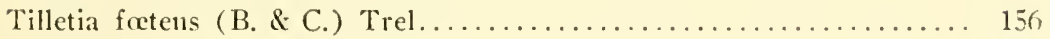

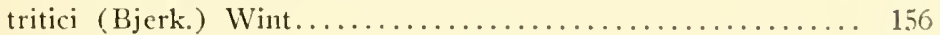

Tuberculina persicina (Ditm.) Sacc...................... 144

Typhodium typhinum (Pers.) Seaver.................... 38

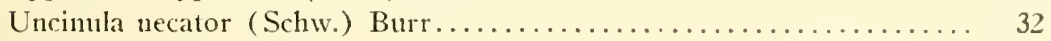

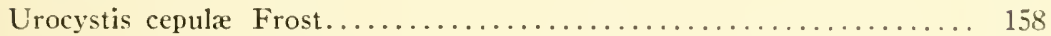

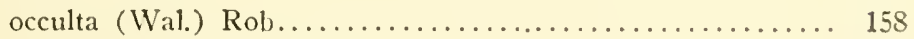

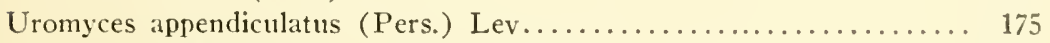

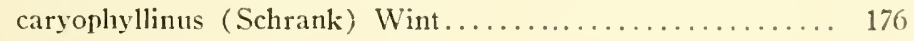

howei (Peck) Arthur.......................... 178

Ustilago anomala J. Kunze........................... 150

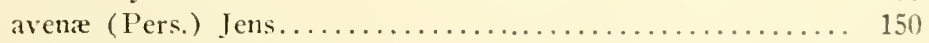

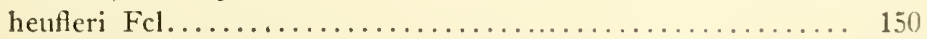

hordei (Pers.) K. \& S......................... 150

levis $(\mathrm{K} . \&$ S.) Magn ........................ 152 
PAGE

Ustilago neglecta Niessl............................ 152

" nuda (Jens.) K. \& S........................ 152

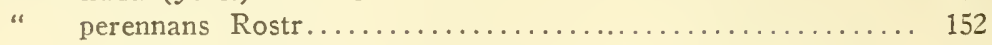

“ pustulata T. \& E............................ 154

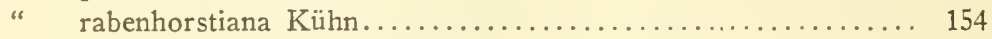

" striaeformis (West.) Niessl......................... 154

“ tritici (Pers.) Rostr.......................... 154

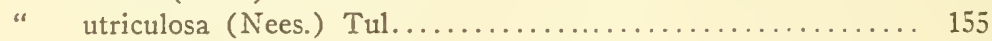

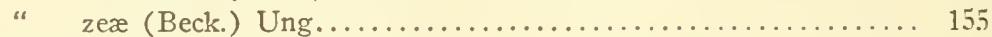

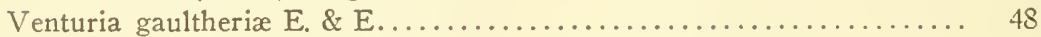

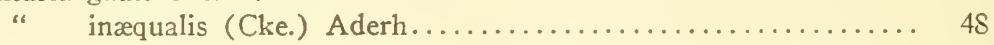

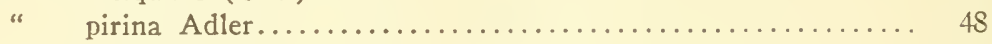

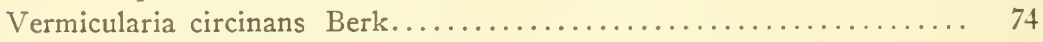

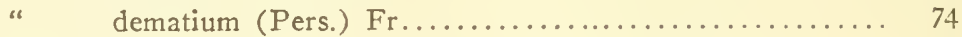

Volutella buxi (Cda.) Berk......................... 144 






\section{QK605.N5 S3}

Schwarze Carl Aloi/The parasitic fungen

II

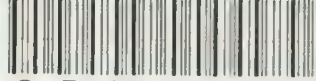

35185001157062 
